\title{
Status en imago van de leraar in de 21 ste eeuw
}

Citation for published version (APA):

Cörvers, F., Mommers, A., van der Ploeg, S., \& Sapulete, S. (2017). Status en imago van de leraar in de 21ste eeuw. ROA. ROA Reports No. 005 https://doi.org/10.26481/umarep.2017005

Document status and date:

Published: 01/01/2017

DOI:

10.26481/umarep.2017005

Document Version:

Publisher's PDF, also known as Version of record

\section{Please check the document version of this publication:}

- A submitted manuscript is the version of the article upon submission and before peer-review. There can be important differences between the submitted version and the official published version of record.

People interested in the research are advised to contact the author for the final version of the publication, or visit the DOI to the publisher's website.

- The final author version and the galley proof are versions of the publication after peer review.

- The final published version features the final layout of the paper including the volume, issue and page numbers.

Link to publication

\footnotetext{
General rights rights.

- You may freely distribute the URL identifying the publication in the public portal. please follow below link for the End User Agreement:

www.umlib.nl/taverne-license

Take down policy

If you believe that this document breaches copyright please contact us at:

repository@maastrichtuniversity.nl

providing details and we will investigate your claim.
}

Copyright and moral rights for the publications made accessible in the public portal are retained by the authors and/or other copyright owners and it is a condition of accessing publications that users recognise and abide by the legal requirements associated with these

- Users may download and print one copy of any publication from the public portal for the purpose of private study or research.

- You may not further distribute the material or use it for any profit-making activity or commercial gain

If the publication is distributed under the terms of Article $25 \mathrm{fa}$ of the Dutch Copyright Act, indicated by the "Taverne" license above, 
Research Centre for Education and the Labour Market | ROA

\section{Status en imago van de leraar in de 21ste eeuw}

\section{ROA Rapport}

ROA-R-2017/5

Researchcentrum voor Onderwijs en Arbeidsmarkt | ROA Research Centre for Education and the Labour Market / ROA 


\section{STATUS EN IMAGO VAN DE LERAAR IN DE 21STE EEUW}

ROA-R-2017/5

Frank Cörvers (ROA)

Ardi Mommers (ROA)

Sjerp van der Ploeg (Ecorys)

Saraï Sapulete (Ecorys) 


\section{Colofon}

(C) Researchcentrum voor Onderwijs en Arbeidsmarkt (ROA). Niets uit deze uitgave mag op enige manier worden verveelvoudigd zonder voorafgaande schriftelijke toestemming van de directeur van het ROA.

\section{Researchcentrum voor Onderwijs en Arbeidsmarkt}

School of Business and Economics

Maastricht University

email: secretary-roa-sbe@maastrichtuniversity.nl

website: www.roa.nl

\section{Redactie en productie}

Researchcentrum voor onderwijs en arbeidsmarkt (ROA)

Ecorys

\section{Vormgeving}

ROA secretariaat, Maastricht

ISBN: 978-90-5321-557-9

mei 2017 


\section{INHOUD}

\section{Voorwoord \\ Resumé}

1 Inleiding

1.1 Aanleiding 1

$\begin{array}{lll}1.2 & \text { Onderzoekskader } & 1\end{array}$

1.3 Achtergronden en het meten van status en imago 3

$\begin{array}{ll}1.4 & \text { Aanpak } \\ & 10\end{array}$

2 Status: indicatoren opleiding en achtergrond 13

$\begin{array}{ll}2.1 & \text { Inleiding } \\ & 13\end{array}$

$\begin{array}{ll}2.2 & \text { Instroom in lerarenopleidingen } \\ & 14\end{array}$

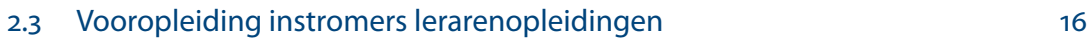

$\begin{array}{lll}2.4 & \text { Eindexamencijfer vooropleiding } & 18\end{array}$

$\begin{array}{ll}2.5 & \text { Rendement lerarenopleidingen } \\ & 19\end{array}$

2.6 Gemiddeld afstudeercijfer lerarenopleidingen 21

2.7 Opleidingsniveau beroepsgroep 22

2.8 Sociale compositie: geslacht 23

2.9 Sociale compositie: leeftijd 24

2.10 Sociale compositie: etniciteit 25

$\begin{array}{ll}2.11 \text { Reflectie } & 26\end{array}$

3 Status: indicatoren arbeidsmarkt $\quad 29$

$\begin{array}{ll}3.1 & \text { Inleiding } \\ 3.2 & \text { Werklosherid onder recent afgestudeerden }\end{array}$

3.2 Werkloosheid onder recent afgestudeerden 29

3.3 Huidige sector afgestudeerden lerarenopleiding 31

$\begin{array}{ll}3.4 & \text { Niveau baan recent afgestudeerden } \\ 34\end{array}$

3.5 Dienstverband recent afgestudeerden 36

3.6 Lonen recent afgestudeerden 38

3.7 Functiemix 42

3.8 Relatieve lonen $\quad 44$

3.9 Reflectie 45 
4 Imago: het beroep leraar

$\begin{array}{lll}4.1 & \text { Inleiding } & 47\end{array}$

4.2 Waardering voor het beroep van leraar $\quad 48$

4.3 Waardering in de loop van de tijd 54

4.4 Mening over beroepsuitoefening 55

4.5 Inschatting van het salaris van leraren 61

$\begin{array}{lll}4.6 & \text { Reflectie } & 63\end{array}$

5 Imago: beroepsprestige vergeleken $\quad 65$

$\begin{array}{lll}5.1 & \text { Inleiding } & 65\end{array}$

$\begin{array}{lll}5.2 & \text { Aanpak } & 65\end{array}$

$\begin{array}{lll}5.3 & \text { Beroepsprestigeladder } & 69\end{array}$

5.4 Vergelijking met eerdere ladders $\quad 73$

$\begin{array}{lll}5.5 & \text { Reflectie } & 78\end{array}$

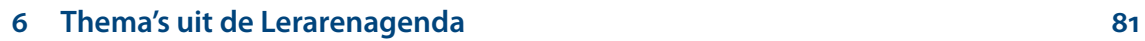

$\begin{array}{ll}6.1 & \text { Inleiding } \\ 6.2 & \text { Lerarenregister }\end{array}$

$\begin{array}{lll}6.2 & \text { Lerarenregister } & 81\end{array}$

6.3 Professionaliseringsactiviteiten 83

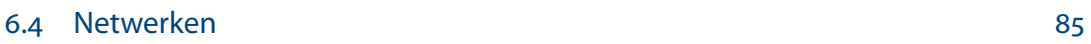

$\begin{array}{lll}6.5 & \text { Relaties met imago } & 87\end{array}$

$\begin{array}{lll}6.6 & \text { Reflectie } & 88\end{array}$

7 Conclusies $\quad 91$

$\begin{array}{lll}7.1 & \text { Status van de leraar } & 91\end{array}$

7.2 Imago van het beroep 95

7.3 De leraar op de beroepenladder 96

$\begin{array}{lll}7.4 & \text { Thema's uit de Lerarenagenda } & 97\end{array}$

$\begin{array}{ll}7.5 & \text { Blik op de toekomst }\end{array}$

$\begin{array}{ll}\text { Referenties } & 99\end{array}$

$\begin{array}{ll}\text { Bijlage I: Methodologische verantwoording } & 103\end{array}$

$\begin{array}{lr}\text { Bijlage II: Responsanalyse } & 107\end{array}$

$\begin{array}{lr}\text { Bijlage III: Sets met beroepen } & 109\end{array}$

$\begin{array}{ll}\text { Bijlage IV: Vragenlijsten } & 111\end{array}$ 


\section{VOORWOORD}

Dit rapport is tot stand gekomen met financiering van het Nationaal Regieorgaan Onderwijsonderzoek (NRO). Wij danken Gitta Snijders en Jelle Kaldewaij voor hun ondersteuning bij het onderzoek.

TNS NIPO (tegenwoordig Kantar Public geheten) heeft zorggedragen voor het grootste deel van het veldwerk. Dit is in goede samenwerking met de onderzoekers van het ROA en Ecorys verlopen. We zijn met name Daan Mager en Suzanne Plantinga van TNS NIPO hiervoor erkentelijk.

Tot slot danken we deelnemers en organisatoren van de diverse bijeenkomsten en workshops waarop we ons onderzoek hebben kunnen presenteren, deels om terugkoppeling op de onderzoeksopzet en (voorlopige) resultaten te krijgen, deels om de resultaten te kunnen uitdragen. Het onderzoek is gepresenteerd op twee expertmeetings bij het CAOP op 10 november 2015 en 7 juni 2016 in Den Haag, bij het Arbeidsmarktplatform Primair Onderwijs (APPO) op 4 oktober 2016 in Zeist en bij het jaarlijkse NRO-congres Onderwijsonderzoek op 2 november 2016 in Amersfoort. 


\section{RESUMÉ}

\section{Achtergrond en opzet}

In 2013 presenteerde het Ministerie van OCW de Lerarenagenda 2013-2020. Deze Lerarenagenda spreekt de ambitie uit dat in 2020 elke school voortdurend bezig is met de kwaliteitsverbetering van het onderwijs. Bij deze ambitie staat de leraar centraal: "De kwaliteit van de leraar bepaalt de kwaliteit van het onderwijs aan leerlingen en studenten". De maatregelen uit de agenda beogen meer autonomie op schoolniveau, betere competenties van de leraren en een grotere verbondenheid met hun beroepsgroep. Via deze maatregelen dient het beroep van leraar aantrekkelijker te worden. Eén van de zeven thema's in de Lerarenagenda betreft een sterke beroepsorganisatie van leraren. De status en het imago van de leraar maken daarvan deel uit. De overige thema's betreffen hogere eisen aan studenten op de lerarenopleidingen, verbeteringen in de kwaliteit van de lerarenopleidingen, het aantrekken van nieuwe doelgroepen voor het leraarschap, de professionele ontwikkeling van startende leraren, de lerende organisatie als standaardmodel voor onderwijsinstellingen en alle leraren bevoegd en bekwaam. De Lerarenagenda heeft daarmee duidelijk een veel breder en omvattender perspectief dan alleen status en imago van de leraar. Dat neemt niet weg dat de verwachting is dat de status van de leraar groeit en het beroepsimago verbetert door de positie en de kwaliteit van de leraar te versterken. Status en imago van leraren is het thema van het voorliggende onderzoek, met als uitgangspunt de onderzoeksvraag:

Hoe is het gesteld met de status en het imago van het lerarenberoep in de 21ste eeuw, en in welke mate is de uitvoering van de Lerarenagenda hierop van invloed?

Bij deze onderzoeksvraag geldt dat naar verwachting vooral de maatregelen binnen de Lerarenagenda die betrekking hebben op de versterking van de beroepsorganisatie, zoals de invoering van het lerarenregister, de status en het imago van de leraar verbeteren. Waar status vooral betrekking heeft op de 'hardere' kwaliteits- en beroepsindicatoren van het leraarschap, gaat imago over de maatschappelijke perceptie van het beroep leraar en het beroepsprestige. Imago wordt doorgaans gemeten door subjectieve of 'zachte' indicatoren. Voor het meten van de status van de leraar zijn in dit rapport bestaande secundaire databestanden gebruikt over de gevolgde opleiding van leraren, de arbeidsmarktpositie en de sociale compositie van de beroepsgroep. Het beroeps- 
imago (de waardering van leraren) en de hiërarchische positie op de beroepenladder (leraren ten opzichte van referentieberoepen) zijn gemeten aan de hand van vragenlijsten onder (diverse groepen) in de Nederlandse bevolking.

\section{Status}

\section{Opleiding}

De omvang van de instroom in de hbo-opleiding leraar vo (voortgezet onderwijs) is de afgelopen tien jaar ruwweg stabiel gebleven. De instroom in de pabo (lerarenopleiding basisonderwijs) is tussen de studiejaren 2006/2007 tot 2015/2016 gehalveerd: van ca. 7.500 tot ca. 3.500. Met name in studiejaar 2015/2016 is de instroom sterk gedaald (met 1.700 inschrijvers), wat samenvalt met een flinke aanscherping van de instroomeisen in dat jaar. Daardoor lijkt het aandeel havo/vwo'ers toegenomen, tegenover een afname van het aandeel mbo'ers. Hoewel de toelatingseisen vooral per 2015/2016 zijn aangescherpt, was in de jaren daarvoor het aandeel pabo-studenten met een vooropleiding van het vwo al toegenomen. Het niveau van de vooropleiding van studenten aan de lerarenopleiding voor het vo neemt daarentegen af: meer mbo'ers en minder vwo'ers. Andere indicatoren die verband houden met de selectie aan lerarenopleidingen zijn onder meer een afname van het diplomarendement na vijf jaar onder de tweedegraads lerarenopleidingen en een kleiner aandeel van afgestudeerden met een gemiddeld eindcijfer 8 of hoger. Deze trends zijn echter niet eenvoudig te interpreteren, ook omdat dezelfde trends bij veel andere hbo-opleidingen zichtbaar zijn.

Van belang is verder de toename van het aantal inschrijvingen in de universitaire lerarenopleidingen (ulo) en de eerstegraads lerarenopleidingen van het hbo, terwijl er een flinke afname is van de inschrijvingen in de overige hbo onderwijsmasters. Dit laatste hangt samen met de afname van de aanvragen voor de Lerarenbeurs.

Het opleidingsniveau van de gehele beroepsgroep leraren is zeer hoog. In die zin is het beroep van leraar als statusrijk te kwalificeren. De langetermijntrend van het opleidingsniveau van de Nederlandse bevolking is echter positief, terwijl deze voor de beroepsgroep leraren vrij stabiel is. De 'exclusiviteit' van leraren als hoogopgeleide beroepsgroep is dus in de loop der jaren afgenomen.

\section{Arbeidsmarktpositie}

De werkloosheid onder pas afgestudeerden van de hbo-opleiding leraar vo ligt al meer dan tien jaar fors onder het hbo-gemiddelde. De werkloosheidsontwikkeling onder pas afgestudeerde leraren van de pabo en de ulo is veel grilliger, soms onder en soms boven het hbo-gemiddelde. In de meting van 2015 (afgestudeerden uit 2014, ca. een jaar na afstuderen) ligt de werkloosheid onder afgestudeerden van zowel de pabo, de tweedegraads lerarenopleiding vo als de ulo relatief laag op ruim 4 procent, tegen een hbogemiddelde van 6 procent. De afgestudeerden van de pabo hebben vergeleken met het totaal van afgestudeerden minder vaak een vast dienstverband, in tegenstelling tot degenen met een tweedegraads lerarenopleiding voor het vo. Voor de afgestudeerden 
van de hbo-masteropleidingen onderwijs zijn de werkloosheidspercentages erg laag en is het aandeel met een vast dienstverband erg hoog, omdat het hier vaak studenten betreft die al als leraar werkzaam waren en die duaal of in deeltijd de lerarenopleiding hebben gevolgd.

Verreweg de meest afgestudeerden van de lerarenopleidingen komen in het onderwijs terecht. Afhankelijk van de databron en het type lerarenopleiding (pabo, eerste- of tweedegraad vo) is dat tussen 70 en 90 procent van de pas afgestudeerde leraren. Voor de hbo-onderwijsmasters is dat zelfs bijna 100 procent omdat zij vaak een baan in het onderwijs combineren met een masteropleiding. Hier blijkt een positieve selectie plaats te vinden: afgestudeerden aan hbo-lerarenopleidingen met een hoger gemiddeld afstudeercijfer hebben een grotere kans om in het onderwijs te werken. Ook hebben afgestudeerden van hbo-lerarenopleidingen een grotere kans om een baan te bemachtigen op (minimaal) hbo-niveau, vergeleken met afgestudeerden van andere richtingen. Als afgestudeerden van lerarenopleidingen echter buiten het onderwijs gaan werken, dan daalt de kans op een baan op niveau met de helft of meer. Over het algemeen is ook het loon lager als men buiten het onderwijs gaat werken.

Afgestudeerden aan de lerarenopleiding voor het vo verdienen relatief goed: het mediane uurloon van deze groep ligt al vele jaren ongeveer 10 procent hoger dan het gemiddelde onder afgestudeerden van het gehele hbo. Afgestudeerde pabo'ers verdienden tussen 1995 en 2005 meer dan andere hbo-afgestudeerden, maar na 2008 is hun mediane uurloon juist lager dan dat van andere hbo-afgestudeerden. Bovendien is de afstand tussen de lonen van de pabo'ers en de overige hbo'ers, en met name tussen pabo'ers en vo-leraren gedurende de laatste jaren steeds groter geworden.

De lonen van de gehele beroepsgroep van leraren, dus niet alleen de recent afgestudeerden, blijken de afgelopen decennia verhoudingsgewijs lager te zijn geworden. Waar het onderwijs in de jaren zestig en zeventig, vergeleken met andere sectoren in het publieke domein, relatief hoge lonen kende, zijn de beloningsverschillen daarna steeds kleiner geworden. De 'exclusiviteit' van het onderwijs in termen van beloning is verkleind. Wel zijn in het kader van de functiemixmaatregel de laatste jaren veel meer leraren in hogere salarisschalen terechtgekomen.

\section{Sociale compositie}

Het onderwijs kent al vijftien jaar een sterke toename in het aandeel vrouwelijke leraren. Van oudsher is het primair onderwijs (po) de sterkst 'gefeminiseerde' sector: in 2015 was bijna negen op de tien leraren vrouw. Dit aandeel is bijna twee keer zo hoog als in de gehele werkzame beroepsbevolking. Het onderwijs is tevens een snel vergrijzende sector. Hoewel dit een landelijk fenomeen is, gaat dit proces bij de leraren veel sneller. Zo is het aandeel 55-plussers in het onderwijs veel hoger dan in andere sectoren: in het voortgezet onderwijs (vo) met ongeveer 30 procent bijna twee keer zo hoog. Onder de leraren in het middelbaar beroepsonderwijs ( $\mathrm{mbo}$ ) is het aandeel 55-plussers zelfs bijna 40 procent. Tot slot blijkt de etnische diversiteit in het onderwijs toe te nemen 
tussen 1998 en 2014, hoewel de diversiteit nog steeds betrekkelijk laag is. Het aandeel niet-westerse allochtonen in het vo en mbo is met respectievelijk 5 en 6 procent in 2014 veel lager dan het landelijke aandeel van 9 procent. In het po is de diversiteit na 2002 afgenomen en heeft nog geen 4 procent van de leraren een niet-westerse herkomst.

Imago

\section{Beroepsimago}

Het imago van de beroepsgroep van leraren in het primair onderwijs (po), voortgezet onderwijs (vo) en middelbaar beroepsonderwijs ( $\mathrm{mbo}$ ) is gemeten door vijf verschillende respondentgroepen te benaderen, namelijk de leraren zelf, de studenten aan de lerarenopleiding, de ouders, de leerlingen (alleen voor vo en mbo) en de Nederlandse bevolking. Het is hier van belang te benadrukken dat de respondenten uit deze groepen telkens is gevraagd naar hun oordeel over hoe de Nederlandse bevolking het leraarschap waardeert ('projectieve' vraagstelling). Hun inschatting van de waardering door de Nederlandse bevolking hebben ze op een schaal van 1 tot 5 aangegeven. De gemiddelde waardering die hieruit voortkwam is niet hoog, namelijk 3,2 voor het po en vo en 3,1 voor het mbo. Ook denken alle vijf de respondentgroepen dat de waardering voor het beroep van leraar over de afgelopen twintig jaar is gedaald. Vooral leraren en studenten aan de lerarenopleidingen schatten de waardering door de Nederlandse bevolking laag in (gemiddeld ongeveer 2,5 op de schaal van 5 ) en denken het vaakst dat deze waardering over de laatste 20 jaar is gedaald. Ouders en de Nederlandse bevolking schatten de waardering door de Nederlandse bevolking gemiddeld een half punt hoger in dan de leraren zelf en de studenten aan de lerarenopleidingen.

Respondenten zijn vrij positief over de kwaliteiten van leraren. Leraren zijn hier, in tegenstelling tot hoe zij de waardering voor hun beroep inschatten, het meest positief over. Leerlingen zijn het minst positief. Ook zien we verschillen tussen de onderwijsvormen: respondenten die hun mening geven over het po zijn positiever dan respondenten die hun mening geven over het vo en mbo. Respondenten over het mbo zijn het meest negatief. Er zijn geen opvallende patronen waar te nemen als het gaat om verschillen in school- en lerarenkenmerken, behalve voor leeftijd. Oudere leraren schatten de waardering van het leraarschap hoger in, evenals de waardering voor de beroepsuitoefening. Het imago wordt verder wellicht beïnvloed door een te lage inschatting van het startsalaris van leraren in het vo door leerlingen, ouders en studenten aan de lerarenopleidingen ten opzichte van het werkelijke startsalaris.

De waardering voor het lerarenberoep wordt niet hoog ingeschat door leraren en studenten van de lerarenopleiding. Als het echter gaat om de kwaliteiten van leraren, zijn leraren en studenten van de lerarenopleiding daar juist weer significant positiever over ten opzichte van de vraagstelling over de waardering. Hier treedt dus een spanningsveld op, waarin leraren vinden dat ze goed werk afleveren, dat in mindere mate gewaardeerd wordt door de samenleving. 


\section{Beroepenladder}

Over het maatschappelijk aanzien van het lerarenberoep is er een vergelijking gemaakt met andere beroepen en een vergelijking van de ontwikkeling over de tijd. Er is wederom gebruik gemaakt van de eerder aangehaalde projectieve vraagstelling, waarbij een representatieve steekproef van de Nederlandse bevolking is bevraagd naar hun oordeel over hoe de Nederlandse bevolking het leraarschap waardeert. Het maatschappelijk aanzien van de leraar verschilt naar het soort leraar. Eerstegraads leraren in het vo genieten het hoogste maatschappelijk aanzien, gevolgd door tweedegraads leraren in het vo, leraren in het mbo en als laatste leraren in het basisonderwijs.

Deze lerarenberoepen nemen een range in van ongeveer 10 procent op de totale ladder van maatschappelijk aanzien van meer dan 100 beroepen in Nederland: op een schaal van o tot 100 bevinden ze zich in de range van 55 tot 65 . Lerarenberoepen worden daarmee redelijk wat maatschappelijk aanzien toegedicht, maar ze behoren zeker niet tot de top. Vergeleken met bijvoorbeeld hooggeschoolde professionals in de gezondheidszorg of juristen (notariaat/advocatuur) geniet de leraar minder maatschappelijk aanzien.

In de Nederlandse studies naar de beroepenladders van de afgelopen 30 jaar komt het beeld naar voren dat het imago van het lerarenberoep nagenoeg niet verandert in de loop van de tijd. De resultaten in het voorliggende onderzoek laten wat dat betreft een trendbreuk zien. Er is in ieder geval voor de eerstegraads leraren in het vo sprake van een neerwaartse trend in maatschappelijk aanzien. Voor de tweedegraads leraren in het basisonderwijs en het voortgezet onderwijs geldt eveneens dat er sprake is van een daling op de beroepenladder, alleen is deze minder sterk.

\section{Lerarenagenda en vervolgonderzoek}

De belangrijkste doelstelling van de Lerarenagenda is het verhogen van de kwaliteit van de leraar en het onderwijs. Professionalisering en een sterke beroepsgroep van leraren zijn daarbij belangrijke thema's die het beroep bovendien aantrekkelijker kunnen maken voor nieuwe lichtingen van studenten en leraren.

Uit het voorliggende onderzoek blijkt dat ongeveer een kwart tot een derde van de leraren zich ten tijde van de enquête in het (op dit moment) vrijwillige lerarenregister had ingeschreven. Zes tiende daarvan gebruikt dat register ook daadwerkelijk en houdt zijn of haar professionaliseringsactiviteiten erin bij. Professionaliseringsactiviteiten van leraren spitsen zich vooral toe op (korte) trainingen/workshops. Binnen een tijdsbestek van één jaar neemt het overgrote deel van de leraren wel aan dit soort activiteiten deel. Daarnaast heeft ook nog eens tussen de 20 en 30 procent van de leraren in het afgelopen jaar deelgenomen aan een vorm van scholing met een kwalificatieprogramma.

Leraren die op verschillende manieren aan hun professionele ontwikkeling werken, blijken niet vaker van mening te zijn dat de bevolking positief tegen het lerarenberoep 
aankijkt. Diverse elementen uit de Lerarenagenda (inschrijving in het lerarenregister, participatie in netwerken, deelname aan professionaliseringsactiviteiten) hangen eveneens niet samen met hoe leraren de waardering van hun beroep door de buitenwereld inschatten. Het lijkt er derhalve niet op dat professionalisering en actieve participatie in beroepsorganisaties het zelfbeeld en de beroepstrots van de leraar beïnvloeden.

Tot slot. De Lerarenagenda is een belangrijk onderwerp in voorliggend onderzoek. Vanuit dat oogpunt dienen de gepresenteerde status- en imago-indicatoren niet alleen als terugblik op de ontwikkelingen in het verleden te worden bezien, maar vooral ook als een situatieschets van de actuele situatie 'hier en nu', oftewel als een 'nulmeting'. Om inzicht te krijgen in de mate waarin de uitvoering van de Lerarenagenda op termijn weet bij te dragen aan de vergroting van de status en de verbetering van het imago van het leraarschap, dienen er herhaalmetingen te worden uitgevoerd. 


\section{INLEIDING}

\subsection{Aanleiding}

Uit internationaal onderzoek van Dolton et al. (2013) blijkt dat het lerarenberoep in het primair onderwijs (po) en het voortgezet onderwijs (vo) bovengemiddeld gerangschikt wordt ten opzichte van 12 andere min of meer vergelijkbare beroepen. Het onderzoek is gehouden onder representatieve steekproeven van de bevolking in 21 landen. Het oordeel over de leraren in Nederland ligt hoger dan het gemiddelde voor de leraren in alle landen. Ook uit het TALIS-onderzoek van de OECD blijkt dat de leraren in de onderbouw van het voortgezet onderwijs in Nederland ten opzichte van andere landen goed scoren op de waardering door de maatschappij, volgens de perceptie van de leraren zelf. Bovendien zijn leraren over het algemeen tevreden over hun baan (Jettinghof en Scheeren, 2010; Stamet, 2013), zijn er weinig leraren met spijt van hun opleiding (ROA, 2013), en waarderen ouders de leraren van hun kind met een ruime 7 op een schaal van 10 (Plantinga et al., 2008).

Toch denkt slechts $40 \%$ van de leraren in het genoemde TALIS-onderzoek dat hun beroep wordt gewaardeerd door de maatschappij (www.trendsinbeeld.minocw.nl). Dit geeft aan dat er nog genoeg ruimte is om het imago en de status van het beroep van leraar te verbeteren. Imago en status kunnen worden gezien als een 'secundaire arbeidsvoorwaarde' die het beroep aantrekkelijker maakt.

\subsection{Onderzoekskader}

Status en imago worden in het conceptueel kader van Bosker et al. (2015) bepaald op macroniveau en zijn van belang vanwege hun invloed op de motivatie en de professionaliteit van de leraar. Volgens Bosker et al. (2015) hangen de (intrinsieke) motivatie van leraren, hun professionaliteitsniveau en de bereidheid tot verdere professionalisering positief samen met meer autonomie op schoolniveau, betere competenties van leraren en een grotere verbondenheid met hun beroepsgroep. Een positievere beeldvorming van de leraar in de maatschappij, waaronder de media, kunnen de verwachtingen ten aanzien van de professionaliteit van leraren doen toenemen. De professionaliteit van de leraar wordt dus mogelijk hoger ingeschat bij een positievere beeldvorming in de samenleving. Dit kan leiden tot hogere verwachtingen bij de beroepsgroep van leraren zelf, en daarmee mogelijk een grotere neiging tot identificatie met het leraarschap. 
Hogere verwachtingen, een hoger competentieniveau en een beter zelfbeeld kan tevens de autonomie van leraren op schoolniveau versterken. Meer status en een beter imago leiden mogelijkerwijs via een zichzelf waarmakende voorspelling ('self-fulfilling prophecy') tot een hogere professionaliteit en motivatie van het zittende lerarenkorps, tot een grotere instroom van studenten op de lerarenopleidingen, en tot het aantrekken van nieuwe leraren met een hoger ambitie- en competentieniveau dan voorheen.

De maatregelen uit de Lerarenagenda 2013-2020 (Ministerie van OCW, 2013) beogen het leraarschap in algemene zin op een hoger niveau professioneel niveau te tillen, waardoor de kwaliteit van het onderwijs zou moeten verbeteren. Deels zijn ze gericht op het bereiken van een hoger kennisniveau van de studenten die van de lerarenopleidingen afstuderen, het behalen van een masteropleiding door de aankomende en zittende leraren, het vergroten van de bekwaamheden van (jonge) leraren, en het introduceren van hogere beroepsstandaarden, waaronder het strikter hanteren van de vereiste bevoegdheden bij de beroepsuitoefening (zie ook Ministerie van OCW, 2014; Inspectie van het Onderwijs, 2014). Deels zijn de maatregelen gericht op het creëren van een lerende schoolorganisatie door professionaliseringsactiviteiten, het streven naar een sterke beroepsorganisatie en het invoeren van een verplicht register voor leraren, waarin alle professionaliseringsactiviteiten worden bijgehouden en kunnen worden verantwoord. De laatstgenoemde maatregelen worden in dit onderzoek nader bekeken in relatie tot status en imago van leraren. Het stimuleren van een positievere beeldvorming over het leraarschap op macroniveau door bijvoorbeeld imagocampagnes, kan in combinatie met deze maatregelen een gunstig effect hebben op de werving en het behoud van leraren in kwantitatieve en kwalitatieve zin.

FIGUUR 1.1 Kader voor onderzoek naar status en imago in relatie tot de Lerarenagenda

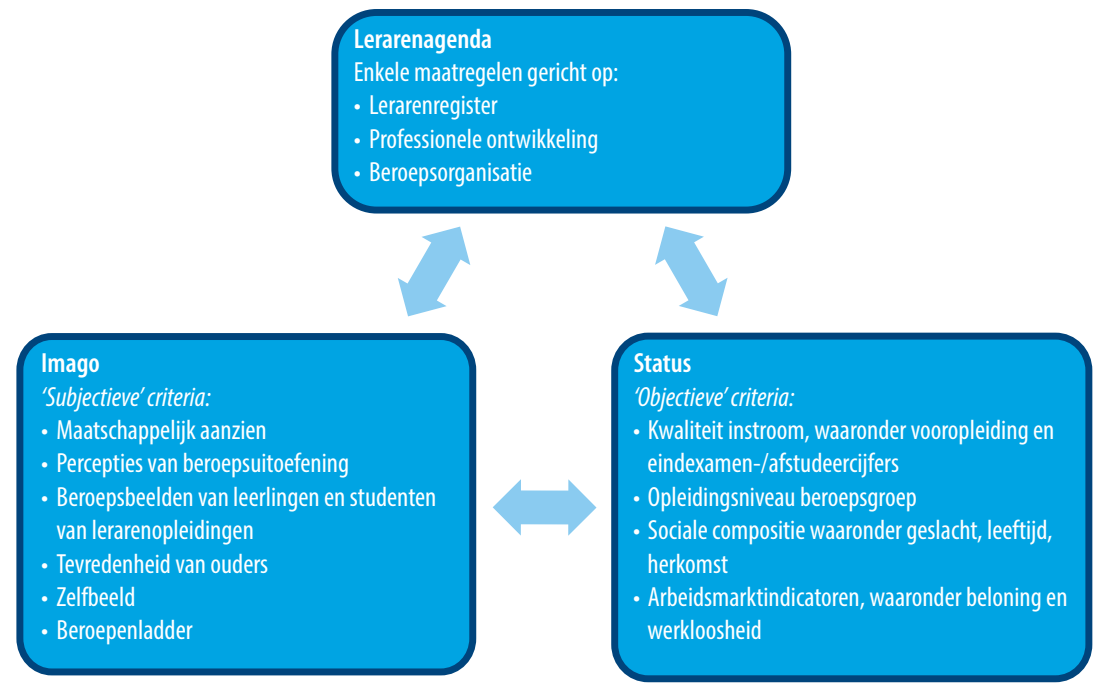


Figuur 1.1 geeft het onderzoekskader weer. Het gaat in het onderzoek vooral om het in beeld brengen van het imago en de status van de beroepsgroep van leraren. De uitvoering van enkele maatregelen in de Lerarenagenda zou moeten bijdragen aan de verbetering van de status en het imago van de leraar. De figuur refereert aan de volgende centrale probleemstelling:

Hoe is het gesteld met de status en het imago van het lerarenberoep in de 21ste eeuw, en is de uitvoering van de Lerarenagenda hierop van invloed?

We maken in dit rapport onderscheid tussen objectieve en subjectieve criteria die samenhangen met respectievelijk status en imago. Van Heek et al. (1958, blz. 13) onderkennen het belang van objectieve criteria zoals inkomen of welstand, geslacht, herkomst en leeftijd voor de realiteit, maar beschouwen tevens "collectieve attitudes ten opzichte van de beroepen (beroeps'beelden' of -stereotypen) als reële aspecten van de sociale stratificatie". Als het gaat om beroepsprestige, waardering (in het Engels: 'respect'), maatschappelijk aanzien (Engels: 'social standing') dan vatten wij dat onder de definitie van 'imago'. Ook perceptie, beroepsbeelden en stereotypen worden onder de definitie van imago geschaard. Een andere term voor imago is sociale status. Deze term zullen we echter niet gebruiken omdat we 'status' als term prefereren om te verwijzen naar de 'economische status'. De term 'status' wordt in wetenschappelijke studies echter vaak in bredere zin gebruikt. In Dolton et al. (2013) refereert men bij'status' aan de sociale status oftewel het imago van het beroep.

\subsection{Achtergronden en het meten van status en imago}

\section{Sociale stratificatie}

De beroepsstatus of het beroepsprestige is in de sociologische literatuur over sociale stratificatie de belangrijkste indicator voor de maatschappelijke positie van een individu (Van Heek et al., 1958). Er wordt vanuit gegaan dat het beroep de 'best single indicator' voor de plaatsbepaling op de maatschappelijke ladder is. Tegelijkertijd wordt erkend dat ook andere factoren een rol spelen bij de sociale stratificatie. Zo wordt er vaak gesproken van twee dimensies die, in navolging van Bourdieu (Ganzeboom et al., 1987; Kalmijn, 1987), van belang zijn voor de maatschappelijke positie. Ten eerste de economische positie, af te lezen aan materiële zaken die verband houden met inkomen en consumptie. Hoog op de ladder staan degenen die zich een luxe levensstijl kunnen veroorloven wat betreft vakanties en hobby's, veel aandacht hebben voor economie en handel, en conservatieve voorkeuren hebben ten aanzien van kunst en politiek. In veel economische beroepen, zoals accountant of bedrijfsleider, kan een hoge positie op deze ladder worden bereikt.

Ten tweede de culturele positie, die verwijst naar de cultuurdeelname en de leefstijl in bredere zin. Hoog op de ladder staan degenen met veel aandacht voor wetenschap en kunst, voor theaterbezoek en literatuur, en progressieve politieke en maatschappelijke opvattingen huldigen. Kunstzinnige beroepen als kunstschilder of acteur, beroepen 
in de wetenschap of het onderwijs zoals hoogleraar en de lerarenberoepen, geven toegang tot de hogere treden op de culturele ladder. Of en in welke mate het beroep en andere factoren belangrijke indicatoren voor sociale stratificatie zijn, wordt in onze studie niet nader onderzocht. Wel trachten we de status en het prestige van beroepen op verschillende manieren te meten.

\section{Meting van beroepsstatus en -imago}

Van oudsher is er discussie over het concept en de meting van de beroepsstatus (Van Heek et al., 1958; Pompe en Rutges, 1984; Ganzeboom et al., 1987). Hoewel de methoden verschillen in conceptuele achtergrond, zijn de schalen die uit de diverse methoden resulteren onderling vaak hoog gecorreleerd, en verschillen ze maar weinig in hun relaties met andere variabelen (Rovers, 2014).

Het schalen van een beroep op een maatschappelijke ladder gebeurt in sociaal-wetenschappelijk onderzoek op drie manieren (Breen en Johnson, 2005; Rovers, 2014), namelijk via: (1) prestigeschalen, (2) sociale afstandschalen en (3) sociaal-economische indices. Aanhakend bij het eerder genoemde recente onderzoek van onder meer Dolton et al. (2013) en Bosker et al. (2015) maken we onderscheid tussen status en imago, respectievelijk de eerste en de derde van de bovengenoemde manieren.

In het concept status komen, met name in sociologische literatuur, meerdere indicatoren vaak terug, voornamelijk indicatoren voor opleiding, inkomen en beroep. Daarnaast wordt de status ook gerelateerd aan diverse persoonlijke karakteristieken, zoals etniciteit (Lenski, 1954) en geslacht (Sullerot, 1969; Bose en Rossi, 1983), of soms zelfs aan de huwelijkse status (Hollingshead, 1975).

In dit rapport bedoelen we de economische status als de term 'status' gebezigd wordt. Status van een beroep refereert hier aan objectieve criteria, in de eerste plaats opleidingsniveau. Hoe hoger het opleiding van een persoon, hoe hoger de status. Ganzeboom et al. (1987) vinden dat opleidingsniveau sterker dan beroep is gerelateerd aan verschillende factoren die samenhangen met de leefstijl van mensen en van invloed zijn op de sociale stratificatie. Opleidingsniveau is derhalve één van de objectieve criteria, die samen met geslacht, leeftijd, herkomst, inkomen en vermogen de sociale stratificatie bepalen. In ons rapport wordt de opleiding van leraren, en in bredere zin de kwalificaties, bevoegdheden en bekwaamheden van leraren, gezien als factor die de economische status van het beroep van leraar meebepaalt.

Wat betreft de meting van het imago van beroepen wordt gebruikt gemaakt van de subjectieve meeting van het maatschappelijk aanzien of het prestige van beroepen. Er zijn er drie min of meer vergelijkbare imago- of prestigemetingen (volgens bovenstaande definities) voor Nederland uitgevoerd sinds de jaren 50, namelijk door Van Heek et al. (1958), Sixma en Ultee (1983) en Groenenwegen (2007). De correlaties tussen de beide eerste beroepenladders zijn erg hoog. Min of meer hetzelfde geldt voor de beroepenladders van 1982 en 2006. In verschillende onderzoeken (Sixma en Ultee, 1983; 
Kalmijn, 1987; Groenewegen et al., 2007; CPB, 2013) wordt geconcludeerd dat er van imagodaling van leraren over het algemeen nauwelijks sprake is. Groenewegen et al. (2007) zien een lichte daling van de positie van de eerstegraadsleraar op het gymnasium. Ook het CPB (2013) stelt dat de maatschappelijke waardering voor het beroep van leraar, gemeten langs de beroepenladder voor maatschappelijk aanzien, sinds de jaren 50 weinig is veranderd.

\section{Sociale compositie van het lerarenberoep}

Wat betreft de sociale compositie van het lerarenberoep kijken we in dit rapport naar geslacht, leeftijd en etniciteit. In het verleden werd de feminisering van een beroep als verlaging van de beroepsstatus gezien, overeenkomstig de 'Wet van Sullerot' (Kalmijn, 1987; Sullerot, 1969). De feminisering van het lerarenberoep kan derhalve een negatieve invloed hebben uitgeoefend op de status van het beroep. Tegenwoordig lijkt deze wet een kleinere rol te spelen door de sterk toegenomen participatie van vrouwen over vrijwel de hele breedte van de arbeidsmarkt. Een toenemende aandeel vrouwen binnen het lerarenberoep kan 'statusverlagend' werken. Overigens zijn er ook diverse publicaties waarin vraagtekens worden gezet bij de relatie tussen sekse en sociale status (Knol en Kooiker, 1986; Faber, 1988). Toch kan deze wet via de loonongelijkheid in het nadeel van vrouwen ten opzichte van mannen (CPB, 2013) nog altijd een rol spelen, omdat het loon één van de objectieve indicatoren is voor de beroepsstatus. Het imago van beroepen waarin veel vrouwen werkzaam zijn, zoals het lerarenberoep, wordt wellicht in negatieve zin beïnvloed door de lage lonen van vrouwen ten opzichte van mannen.

Gedegen onderzoek naar de samenhang tussen de leeftijdsopbouw en sociale status van beroepen lijkt er niet te zijn. Toch wordt er regelmatig gesuggereerd dat vergrijsde beroepen minder aantrekkelijk zijn (o.a. Melser, 2004; Van Eck en Heemkerk, 2009). Voor jongeren kan een vergrijsd beroep een negatief imago hebben. Dat kan tot gevolg hebben dat jongeren het minder aantrekkelijk vinden om te kiezen voor een lerarenopleiding, of om het lerarenberoep uit te (blijven) oefenen.

Niet-westerse allochtonen hebben gemiddeld genomen een lager opleidingsniveau, verdienen gemiddeld een lager inkomen en werken vaker op lagere beroepsniveaus (o.a. Langenberg en Lautenbach, 2007; Lautenbach en Otten, 2007). Zelfs wanneer gecorrigeerd wordt voor opleidings- en beroepsniveau, blijken eerste generatie niet-westerse allochtonen minder te verdienen dan allochtonen (De Mooij et al., 2010). De status van een beroep waarin veel allochtonen werken is dus wellicht, zelfs bij een gelijkwaardig opleidingsniveau, lager dan gemiddeld door het gemiddeld lagere inkomen. De status van beroepen kan derhalve samenhangen met het aandeel niet-westerse allochtonen binnen beroepen.

\section{Projectieve vraagstelling bij imago}

Voor de meting van het imago van het beroep van leraar grijpen we terug op de studie van Van Heek et al. (1958). In deze studie over de sociale stratificatie door middel van beroepsprestigemeting is de aanzet gegeven voor de latere studies van Sixma en Ultee 
(1983) en Groenenwegen et al. (2007). In Van Heek et al. (1958, blz. 16) wordt gevraagd naar "het maatschappelijk aanzien, dat de beoefenaar van een bepaald beroep in de ogen van de ondervraagde ("ranker") geniet." In deze en de latere studies is deze projectieve wijze van bevraging de standaardmethode voor de meting van het imago van een beroep. Het gaat er daarbij niet om welk aanzien de ondervraagde zelf toekent aan een beroep (subjectief), maar om de vaststelling hoe de maatschappij aankijkt tegen het beroep. Ter illustratie tonen wij de opdracht die respondenten kregen in het onderzoek van Sixma en Ultee (1983).

"Bij deze vraag gaat het om het aanzien dat in onze maatschappij aan verschillende beroepen wordt toegekend. Het gaat hierbij niet om het aanzien zoals $U$ dit zelf aan de beroepen zou toekennen, maar om het aanzien zoals $U$ denkt dat het in onze maatschappij wordt toegekend, dus zoals men er in het algemeen over denkt. Op deze kaartjes vindt $U$ de namen van 28 beroepen. Wilt $u$ deze 28 beroepen op volgorde leggen naar aanzien. Het beroep dat naar Uw mening het meeste aanzien heeft, wat het hoogst staat aangeschreven, komt bovenaan te liggen; het beroep dat in onze maatschappij het minste aanzien heeft, wat het laagst staat aangeschreven, komt onderop."

(De volgorde van de beroepen werd door de enquêteur of enquêtrice overgenomen op de vragenlijst.)

Sixma en Ultee (1983) geven aan dat het gaat om het vaststellen van de situatie zoals die in de maatschappij leeft. Wij constateren dat hier sprake lijkt te zijn van dubbele subjectiviteit: er wordt aan mensen gevraagd hoe zij denken (subjectief) dat beroepen binnen de maatschappij zijn geordend (subjectief) op basis van aanzien. Sixma en Ultee (1983) motiveren een projectieve vraagstelling door de verwachting dat een subjectieve vraagstelling over het aanzien van beroepen het risico herbergt dat respondenten aangeven dat voor hen iedereen gelijk is. De onderzoekers willen vermijden dat er sociaalwenselijke antwoorden worden gegeven, en vragen derhalve niet naar de persoonlijke waardering van respondenten voor beroepen. De optelling van de uitkomsten van de projectieve vraagstelling is wezenlijk anders dan een aggregaat van alle individuele rangordeningen die de respondenten zelf toekennen aan beroepen.

Bovendien menen wij dat de projectieve vraagstelling terecht erop inspeelt dat het imago van leraarschap, gedefinieerd als het (collectieve) aanzien in de maatschappij, van invloed is op het gedrag van individuen, los van de persoonlijke waardering die iemand heeft voor het leraarschap. Ter illustratie van dat het laatste: iemand kan persoonlijk veel waardering voor een bepaald automerk hebben, zoals in vroegere tijden een Japans merk, tegenwoordig bijvoorbeeld een Roemeens merk, maar desondanks het gevoel hebben dat een dergelijk merk in de maatschappij minder aanzien heeft, en daarom liever in een Duitse auto rijden. Ook hier gaat het erom hoe iemand inschat wat anderen denken ('Wat men denkt?') van een product of dienst, met andere woorden het 
imago, en dat hij of zij zich daaraan iets gelegen laat liggen wat betreft de waardering (de statusgevoeligheid) en het eventueel daarop volgende keuzeproces. Wat iemand er persoonlijk over denkt, al dan niet impliciet onder invloed van het collectief, speelt uiteraard eveneens een rol, wellicht zelfs een belangrijkere rol in relatie tot zijn of haar voorkeuren en uiteindelijke keuze.

Een belangrijke veronderstelling in dit rapport is dat een persoon die een keuze maakt voor een beroep gevoelig is voor wat er in de maatschappij leeft, en naast de persoonlijke voorkeuren ook het imago of het maatschappelijk aanzien van het beroep bij het keuzeproces betrekt. Bij een projectieve vraagstelling van het maatschappelijk aanzien gaat het niet om wat een persoon zelf denkt over een beroep (of product of dienst in marketing- en reclame-onderzoek), maar gaat het uitsluitend om wat hij of zij denkt dat anderen ervan vinden. In het hier voorliggende onderzoek wordt voor bijna alle enquêtevragen over het imago van het lerarenberoep aangesloten bij deze projectieve vraagstelling. De projectieve vraagstelling is in het meer recente internationale onderzoek nog steeds de gebruikelijke wijze van bevraging. Zo wordt in de studie van Dolton et al. (2013) aan de respondent gevraagd antwoord te geven op "How well do you think the following occupations are respected?"

\section{Professionalisering en professionele identiteit}

Vanuit theoretisch perspectief is de professionalisering van de leraar te beschouwen als een versterking van de professionele identiteit. We noemen hier de professionele identiteit omdat dit begrip raakvlakken heeft met de status en het imago van het leraarschap. Volgens De Koning en Kroon (ed.,2011) kan een leraar die voldoende professionele identiteit heeft ontwikkeld een 'zelfverhaal' vertellen en antwoorden geven op de vragen "Wie ben ik als leraar? Wie wil ik zijn als leraar? Kan ik de leraar zijn die ik wil zijn in deze school?" Beroepstrots is te beschouwen als de beleving van de professionele identiteit, en daarbij spelen de professionele autonomie en het zelfbeeld van de leraar waarschijnlijk een belangrijke rol. We zullen hier niet ingaan op de vraag op welke wijze al deze begrippen met elkaar samenhangen. Opleiding, scholing, vakmanschap en registers lijken in elk geval relevante factoren te zijn die de beroepsstandaard vorm geven en daarmee bijdragen aan de arbeidsidentiteit. In het raamwerk van De Koning en Kroon (ed., 2011) dragen de vorming van de arbeidsidentiteit en persoonlijke identiteit van de leraar bij aan de ontwikkeling van de professionele identiteit. De professionele identiteit van de leraar is bovendien onderhevig aan invloeden uit de schoolidentiteit (organisatie, personeelsbeleid, werkomgeving, leidinggevende, ouders) en de omgeving (beroepsorganisaties, media, lerarenbeleid, etc.). Dit wordt weergegeven in Figuur 1.2. 
FIGUUR 1.2 Professionele identiteit als resultante van de arbeidsidentiteit, de persoonlijke identiteit en de schoolidentiteit volgens De Koning en Kroon (ed., 2011)

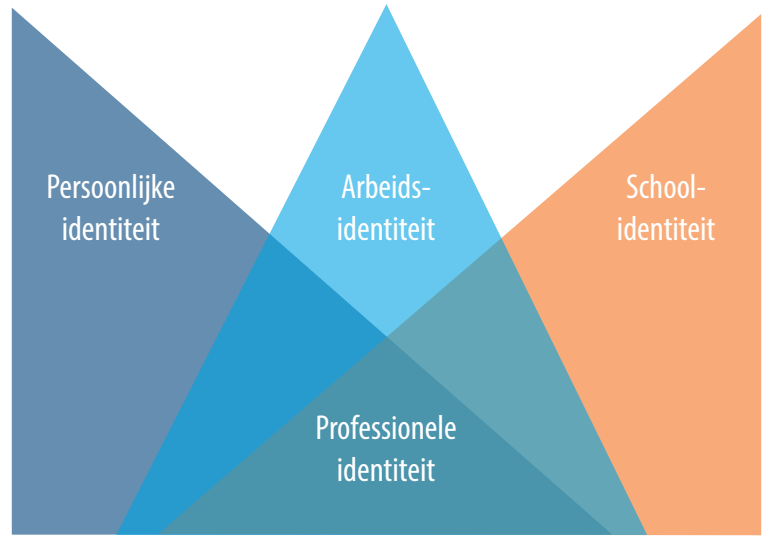

\section{Samenhang tussen professionalisering, status en imago}

In dit rapport staan de begrippen professionalisering en status en imago van leraren centraal. Verbetering van de status van het leraarschap hangt samen met de eerder genoemde objectieve kenmerken, vooral een hoger opleidingsniveau en een hoger salaris, maar ook de bevoegdheid om les te geven. Verbetering van het imago van het leraarschap heeft zoals gezegd betrekking op de subjectieve kenmerken van het beroep. Het gaat hier dan met name om hoe het leraarschap in de maatschappij wordt gepercipieerd, dus de waardering voor de leraar en het maatschappelijk aanzien in absolute zin of ten opzichte van andere beroepen. Status en imago kunnen elkaar wederzijds beïnvloeden, al dan niet met vertraging. Zo zal een lagere status door een lagere beloning afbreuk kunnen doen aan het imago van het leraarschap als aantrekkelijke en belangrijke beroepsgroep. Omgekeerd kan minder aandacht voor het leraarschap en voor de professionalisering van de leraar, in samenhang met een lager maatschappelijk aanzien van de leraar, leiden tot minder goede arbeidsvoorwaarden en een lager loon.

Er wordt hier van uitgegaan dat de status van het beroep van leraar en het imago van het leraarschap belangrijk zijn voor de aantrekkelijkheid van het beroep. Dat wil zeggen dat jongeren vanwege een statusverhoging of imagoverbetering van het beroep van leraar zich meer aangetrokken voelen om te kiezen voor een lerarenopleiding of het lerarenberoep. Zittende leraren zullen wellicht minder snel uitstromen naar een andere sector of ander beroep. Een goed imago van het lerarenberoep zou tevens (tijdelijk) compenserend kunnen zijn voor een lager dan marktconform salaris, ook al zou het imago er op termijn onder kunnen lijden. Er is echter geen hard empirisch bewijs dat imagoverbetering leidt tot een groter aanbod van leraren, of tot een kwaliteitsverbetering in de pool van leraren (CPB, 2016). 


\section{Gedrags- en selectie-effecten}

Verbetering van de status en het imago van het leraarschap kan volgens ons op twee manieren bijdragen aan de professionalisering van de beroepsgroep. Ten eerste kan er een gedragseffect uitgaan van een hogere status of een beter imago. Een hogere status kan samenhangen met gunstigere arbeidsvoorwaarden (en andere objectieve kenmerken van het leraarschap). Een beter imago kan ontstaan door meer maatschappelijk aanzien (als subjectieve factor), bijvoorbeeld wanneer het belang van goede leraren voor de ontwikkeling van kinderen of voor de economische ontwikkeling van Nederland wordt benadrukt. Aankomende en zittende leraren kunnen geneigd zijn meer inspanningen te willen leveren door de betere arbeidsvoorwaarden, en/of geneigd zijn de hogere verwachtingen van de buitenwereld (de maatschappij) waar te willen maken. Daardoor kan de verwachting van een hogere status en een beter imago van het lerarenberoep een zichzelf waarmakende voorspelling worden ('self-fulfilling prophecy'). Een positief gedragseffect behelst dat leraren zich graag identificeren met de hogere standaarden en de toegenomen beroepstrots en op een hoger plan gaan functioneren dan voorheen, met meer (zelf-)effectiviteit in het lesgeven en betere leerprestaties van leerlingen tot gevolg. Meer aanzien kan via de 'self-fulfilling prophecy' leiden tot een hogere standaard voor verantwoordelijkheid, een duidelijkere professionele identiteit, meer autonomie en professionele ontwikkeling, meer zelfvertrouwen van leraren en meer vertrouwen van ouders en leerlingen in de leraar, maar ook meer vertrouwen van de schoolleiders en de politiek (als afspiegeling van de maatschappij) in de leraar.

Ten tweede kan er sprake zijn van een selectie-effect van een beter imago onder zowel aankomende studenten in de lerarenopleidingen als onder zittende leraren. Er kan van uit worden gegaan dat een hoger ambitieniveau specifieke groepen van studenten aantrekt dan wel meer professionals doet behouden voor het leraarschap die zelf ook deze hoge ambities hebben. Statusverhoging zal juist diegenen aantrekken die zich aangesproken voelen door de hogere verwachtingen en het hogere ambitieniveau. Ook zullen vooral de meer bekwame leraren zich graag identificeren met hun beroep, en minder geneigd zijn om uit te kijken naar een ander beroep. We gaan ervan uit dat status en imago van de beroepsgroep een positief selectie-effect hebben op wie wel of niet het beroep van leraar uitoefenen, zowel in kwantitatieve als in kwalitatieve zin. Een hogere status door gunstigere arbeidsvoorwaarden (zie ook Dolton en Marcenaro-Gutierrez, 2011) kan via het selectie-effect de aantrekkingskracht van het beroep vergroten, zodat er meer instroom is in de lerarenopleidingen en in het lerarenberoep. Ook loonsverhogingen, als objectieve indicator voor statusverbetering, kunnen leiden tot een groter en kwalitatief beter aanbod van nieuwe en zittende leraren (Cörvers, 2014).

Verwacht mag worden dat de status en het imago van het leraarschap afnemen bij lagere eisen aan de (instroom van de) lerarenopleidingen, minder aandacht voor bevoegd- en bekwaamheden, lagere salarissen en slechtere arbeidsvoorwaarden, en bij een tekortschietende aandacht voor de professionele identiteit van leraren. Het betreft echter een wisselwerking: een lagere status en een slechter imago kunnen via gedrags- en selectieeffecten tevens de instroom en het functioneren van leraren op een lager plan brengen. 
Bedenkingen bij het imago en de kwaliteit van het lerarenkorps in Nederland leven al sinds het ontstaan van het onderwijs (Boekholt en De Booy, 2002). Kalmijn (1987) wijst op de slechte rekenvaardigheid van studenten van de Pedagogische Academie in 1987 ten opzichte van 1960. Daarbij is het beroep van onderwijzer in het basisonderwijs of docent in het voorgezet onderwijs en het middelbaar beroepsonderwijs niet meer het belangrijke sociale stijgingskanaal van de 6o'er jaren. De zorgen over het imago van de leraar kunnen verder zijn aangewakkerd door meer inspraak van ouders en de "ontmythologisering" van het beroep van leraar, waarbij tevens het stijgende opleidingsniveau van de gemiddelde ouder, en dus het relatieve dalende opleidingsniveau van leraren een rol kan spelen.

\subsection{Aanpak}

In dit rapport wordt gekeken naar de ontwikkeling van de status onder (pas afgestudeerde) leraren gedurende de afgelopen periode, en het imago onder studenten in de lerarenopleidingen, de leraren zelf, de ouders van leerlingen en de bevolking in het algemeen. Er wordt nagegaan of er een relatie is tussen enkele maatregelen uit de Lerarenagenda en het imago van de beroepsgroep van leraren. Er wordt specifiek gekeken naar of er een relatie is tussen enerzijds het imago van de beroepsgroep van leraren en anderzijds de inschrijving in het lerarenregister, de diverse professionaliserings-activiteiten van leraren, en de deelname in netwerken, waaronder beroepsorganisaties. Er wordt doorgaans onderscheid gemaakt tussen drie sectoren in het onderwijs: het primair onderwijs (po), het voortgezet onderwijs (vo) en het middelbaar beroepsonderwijs (mbo).

Op basis van het voorgaande formuleren we de volgende onderzoeksvragen:

- Wat is de status van het beroep van leraar in po, vo en mbo (in termen van met name opleiding en beloning)? Wat is de ontwikkeling van de status geweest in de afgelopen jaren?

- Wat zijn de kenmerken van de instroom in de lerarenopleiding die relevant zijn voor de status van leraren (met name opleidingsniveau en examencijfers)?

- Wat is het imago (of prestige) van het beroep van leraar in po, vo en mbo anno 2016. Hoe varieert dat naar diverse groepen: leraren zelf, studenten op de lerarenopleidingen, leerlingen in de laatste klassen van havo-vwo en het mbo (sociaal pedagogische richtingen), ouders van leerlingen in po, vo en mbo, de Nederlandse bevolking als geheel? Wat is de ontwikkeling van het imago van het beroep in vergelijking met eerdere metingen?

- Welke verbanden zijn aanwijsbaar tussen activiteiten in het kader van de Lerarenagenda (en andere professionaliseringsactiviteiten) en status en imago van de leraar? 
In dit rapport worden de resultaten van status en imago van leraren in de 21e eeuw gepresenteerd. In de volgende twee hoofdstukken (hoofdstuk 2 en 3) wordt gekeken naar de ontwikkeling van de objectieve kenmerken die met de positie van leraren kunnen samenhangen, met andere woorden de ontwikkeling van de status van het leraarschap. Hoofdstuk 2 gaat in op ontwikkelingen in diverse opleidingskenmerken van leraren zoals het niveau van de vooropleiding, het diplomarendement van lerarenopleidingen en het relatieve opleidingsniveau ten opzichte van andere beroepen. Tevens wordt in hoofdstuk 2 aandacht besteed aan (veranderingen in) de sociale compositie van het lerarenberoep. Hoofdstuk 3 beschrijft ontwikkelingen in de arbeidsmarktpositie van leraren, zoals werkloosheid, de aansluiting tussen opleiding en werk en de (relatieve) lonen. In de hoofdstukken 2 en 3 wordt de aandacht vooral gericht op de hbobacheloropleidingen 'pabo' en 'leraar vo'. De hbo-onderwijsmasters en de universitaire lerarenopleidingen (ulo) zijn door het kortlopende en vaak duale of deeltijdkarakter niet goed vergelijkbaar met deze reguliere hbo-bacheloropleidingen. Waar mogelijk wordt niettemin ook aan de hbo-onderwijsmasters en de ulo enige aandacht besteed.

In hoofdstuk 4 wordt er gekeken naar het maatschappelijk aanzien van het lerarenberoep in absolute zin, dat wil zeggen de gemiddelde score van het imago van het lerarenberoep op een schaal van één tot vijf. Voor het imago-onderzoek worden vijf verschillende groepen bevraagd: leraren, studenten lerarenopleidingen, scholieren in laatste twee jaar havo/vwo en mbo sociaal-pedagogiek, ouders van leerlingen in po/vo/mbo, algemene bevolking. In hoofdstuk 5 worden de resultaten van de meting van het imago van het leraarschap in relatieve zin gepresenteerd, dat wil zeggen ten opzichte van meer dan 100 andere beroepen. In hoofdstuk 6 komen enkele relaties tussen de professionaliseringsmaatregelen in de Lerarenagenda en het imago van leraren aan de orde. Nagegaan wordt in hoeverre inschrijving in het lerarenregister, gebruikmaking van de leraren- en promotiebeurs, en het gebruik van netwerken van leraren verband houden met het zelfbeeld van leraren. Hoofdstuk 7 sluit af met de conclusies.

Tot slot van deze inleiding vinden we het van belang te wijzen op enkele doelstellingen en beperkingen van het onderzoek. Van belang is dat de doelstelling van het onderzoek een nulmeting was van status en imago van het beroep, met de mogelijkheid tot herhaling. Dit betekent dat we zoveel mogelijk gebruik hebben gemaakt van landelijke bronnen die over enkele jaren opnieuw te gebruiken zouden moeten zijn. Ten tweede behelst het onderzoek feitelijk een monitor van status en imago van leraren, in relatie tot enkele professionaliseringsmaatregelen in de Lerarenagenda. Om zicht te krijgen op hoe en in welke mate de uitvoering van de Lerarenagenda effect heeft gehad op status en imago, dient deze monitor over drie tot vijf jaar opnieuw uitgevoerd te worden. Ten derde kan het onderzoek niet beschouwd worden als een effectonderzoek van de Lerarenagenda. Niet alleen zijn daarvoor de maatregelen in de Lerarenagenda te divers en te verspreid over de tijd, ook zijn er zoveel andere invloeden en maatschappelijke trends die samen kunnen hangen met de status en het imago van leraarschap. Eenduidige oorzaken van veranderingen in status en imago zijn daardoor moeilijk toe te wijzen aan maatregelen in de Lerarenagenda. Het is vrijwel onmogelijk om met een 
monitor causale effecten van maatregelen in de Lerarenagenda op status en imago te identificeren. We trachten wel een rudimentaire peiling te doen van het gebruik van faciliteiten die met de Lerarenagenda worden voorzien, in samenhang met onder meer het zelfbeeld van leraren. 


\section{STATUS: INDICATOREN OPLEIDING EN ACHTERGROND}

\subsection{Inleiding}

In dit hoofdstuk worden diverse ontwikkelingen rondom de (studenten aan de) lerarenopleidingen belicht die van invloed kunnen zijn op de status van het leraarschap. We richten ons hierbij voornamelijk op de hbo-(voltijd)bachelors 'pabo' en 'leraar vo'. Dit zijn reguliere opleidingen, daar waar hbo-onderwijsmasters en universitaire lerarenopleidingen (ulo) doorgaans kortlopende (één of twee jaar indien voltijds gevolgd) aanvullende opleidingen zijn, die vaak in deeltijd of duaal gevolgd worden. Dat wil zeggen: opleidingen waarvoor een (relevante) hbo- of wo-vooropleiding benodigd is. De hboonderwijsmasters en de ulo zijn daarom niet goed vergelijkbaar met de reguliere hbobacheloropleidingen 'pabo' en 'leraar vo'. Wel zullen we in dit hoofdstuk, waar mogelijk, enige aandacht schenken aan deze hbo-masters en ulo's. Met 'hbo-master' wordt hier bedoeld: de eerstegraads lerarenopleidingen enerzijds en andere onderwijsmasters anderzijds (voornamelijk de master 'special educational needs' en de master 'leren en innoveren'). Met 'ulo' wordt bedoeld de eerstegraads lerarenopleiding op universiteiten.

Naast ontwikkelingen in de lerarenopleiding kijken we ook naar ontwikkelingen in de sociale compositie van de beroepsgroep: we brengen de (veranderende) opbouw van het personeelsbestand naar geslacht, leeftijd en etniciteit in kaart. De sociale compositie kan, net als (onder meer) het opleidingsniveau van leraren, samenhangen met de status van het beroep (o.a. Sullerot, 1969). De verschillende statusindicatoren die in dit hoofdstuk aan bod komen, zijn - zoals het woord al zegt - indicatief en derhalve niet altijd eenduidig te interpreteren, noch staan de indicatoren op zichzelf2. De gepresenteerde gegevens dienen dan ook zoveel mogelijk in zijn geheel te worden bezien. In dit hoofdstuk maken we waar mogelijk onderscheid tussen studenten aan de pabo en aan de opleidingen voor leraar vo, dan wel tussen de onderwijssectoren primair onderwijs (po), voortgezet onderwijs (vo) en middelbaar beroepsonderwijs (mbo).

$1 \quad$ Met de hbo-bacheloropleiding 'leraar vo' wordt bedoeld: de diverse tweedegraads lerarenopleidingen en de lerarenopleiding voor de zogenaamde 'ongegradeerde' opleiding 'leraar lichamelijke opvoeding'.

2 Zo kan een verbetering in het diplomarendement bijvoorbeeld duiden op een verbeterde opleidingskwaliteit, maar ook op een verlaging van de afstudeervereisten. Ontwikkeling in diplomarendement kan derhalve zowel statusverhogend als -verlagend werken: de gepresenteerde indicatoren dienen derhalve altijd in relatie tot elkaar beschouwd te worden. 


\subsection{Instroom in lerarenopleidingen}

\section{Hbo-bachelors}

In de periode 2006-2015 is zowel de relatieve als de absolute instroom in de opleiding voor 'leraar vo' ruwweg stabiel gebleven (Figuur 2.1). Jaarlijks vormt de instroom in de opleiding 'leraar vo' ongeveer 4 procent van de totale instroom (van voltijd bachelorstudenten) in het hbo. In absolute aantallen betreft het jaarlijks ongeveer 3.500 studenten. De instroom in de pabo is in dezelfde periode echter sterk teruggelopen, dit geldt zowel voor de relatieve als de absolute instroom. Waar in 2006 nog 10 procent van de hboinstromers voor de opleiding 'leraar basisonderwijs' koos, betreft dit in 2015 nog maar 4 procent. Met name tussen 2014 (instroomaandeel van 6\%) en 2015 (4\%) is de afname groot. De absolute instroom is tussen 2006 en 2015 eveneens fors afgenomen, van ruim 7.400 in 2006 tot ongeveer 3.500 in 2015 . Een eenduidige verklaring voor deze sterke afname is niet te geven. Vermoedelijk spelen de recente aangescherpte selectiecriteria op de pabo hierbij een belangrijke rol $^{3}$, zeker gezien de forse instroomverschillen tussen 2014 en 2015. Maar ook andere factoren kunnen (mede) van belang zijn, zoals ontwikkelingen in het arbeidsperspectief of het beroepsimago. Voorlopige cijfers van Studielink lijken erop te wijzen dat de instroom in de pabo per 2016/2017 weer met 8 tot 10 procent is gegroeid.

FIGUUR 2.1 Instroom hbo lerarenopleidingen 'relatief' (als percentage van totale instroom hbo) en 'absoluut' (aantallen instromers), alleen voltijd-bachelors, 2006-2015

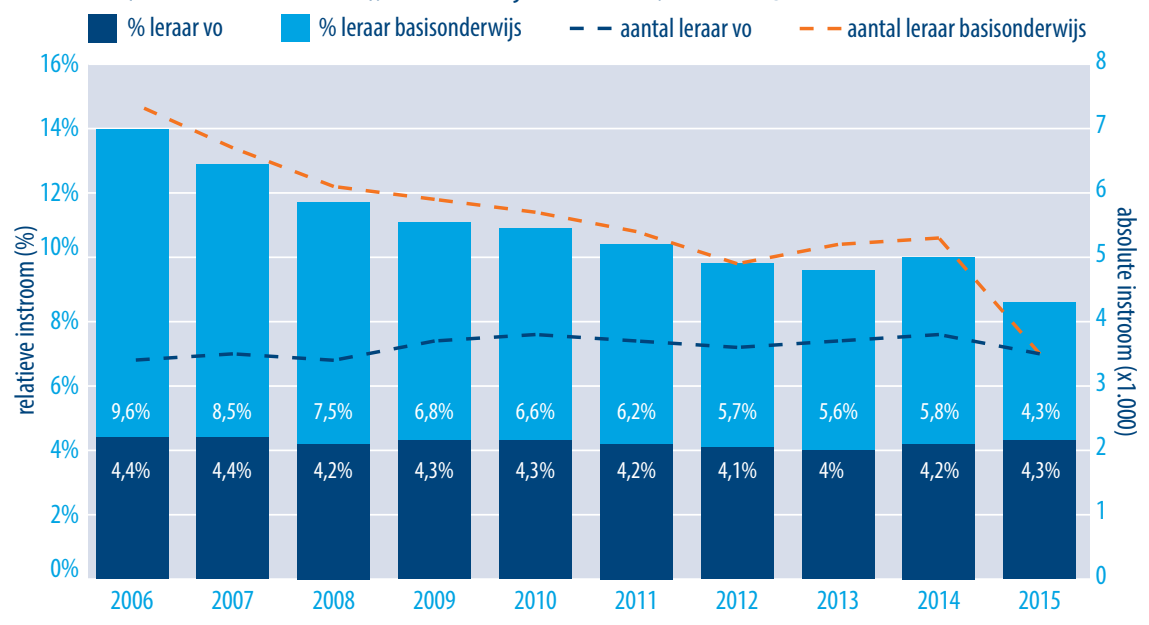

Bron: DUO, 1cijferHO (verkregen via Vereniginghogescholen.nl)

3 Met ingang van 2015-2016 gelden bijzondere nadere vooropleidingseisen voor de pabo. Zie bijvoorbeeld de Kamerbrief van minister Bussemaker en staatssecretaris Dekker van 4 november 2015 betreffende de voortgang over de Lerarenagenda (Ministerie van OCW, 2015). 


\section{Hbo-masters en universitaire lerarenopleidingen}

Waar voorgaande figuur zich richtte op de instroom van studenten aan hbo-bachelor lerarenopleidingen, kijken we voor de hbo-masters en ulo's naar het aantal inschrijvingen. Met name bij de ulo gaat het vaak om doorstromers vanuit het hoger onderwijs, waardoor zij geen 'nieuwe' instromers zijn ${ }^{4}$. Het is derhalve zinvoller om naar het aantal inschrijvingen te kijken. In Figuur 2.2 is te zien dat het aantal studenten aan de eerstegraads opleidingen (zowel hbo-master als ulo) ten opzichte van 2008 in de daaropvolgende jaren is toegenomen. Bij de eerstegraads hbo-master deed de groei zich vooral voor in 2008 tot 2010 (in deze periode 35\% toename), waarna het zich ruwweg stabiliseerde. Bij de ulo groeide het aantal studenten vooral tussen 2008 en 2011 (in deze periode $58 \%$ groei).

Tegenover de (relatief forse) groei in het aantal eerstegraads studenten, staat een sterke daling in het aantal studenten dat een andere hbo-onderwijsmaster volgde. In de periode 2010-2012 daalde het aantal inschrijvingen met een derde (34\%), vervolgens stabiliseerde het aantal studenten zich. Het is waarschijnlijk dat hier sprake is van samenhang met de Lerarenbeurs ${ }^{5}$, in de periode 2008-2011 was het aantal aanvragen voor deze beurs namelijk veel groter dan in de daaropvolgende jaren.

FIGUUR 2.2 Aantallen inschrijvingen hbo-onderwijsmasters en universitaire lerarenopleidingen (voltijd en deeltijd/duaal), 2008-2015

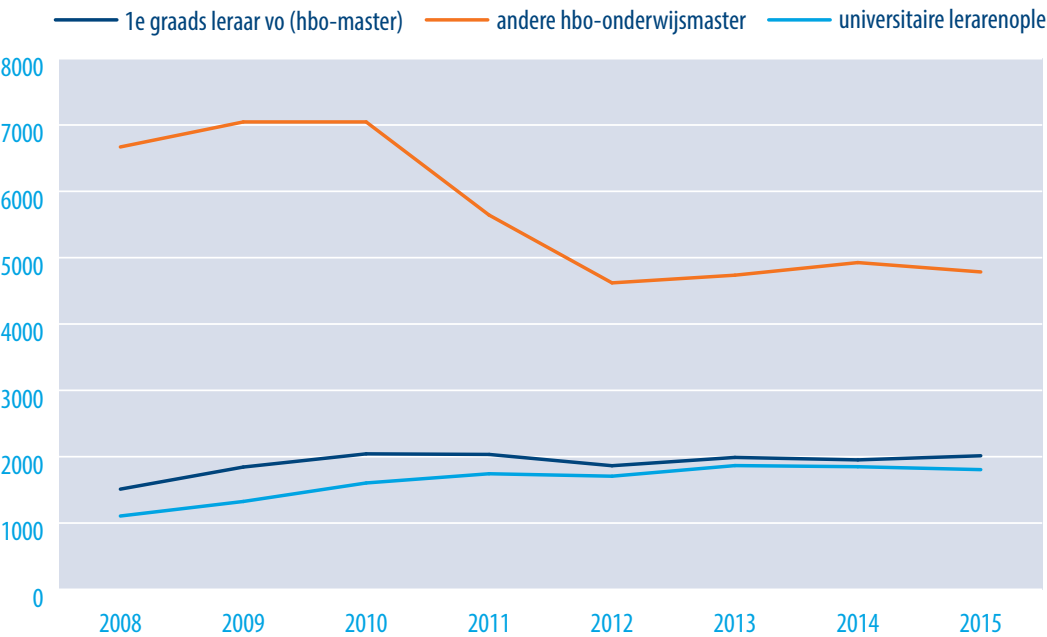

Bron: DUO, 1cijferHO (verkregen via Vereniginghogescholen.nl en VSNU.nl)

4 Zo hanteert de VSNU de volgende instroom-definitie: "in voorgaande studiejaren niet aan een universiteit ingeschreven. Zie: http://www.vsnu.nl/files/documenten/Feiten_en_Cijfers/Basistabel_Instroom_ MN_20160209.xls

5 "De lerarenbeurs is in 2008 ingesteld voor bestaande leraren om een bachelor- of masteropleiding te volgen. Het doel van de lerarenbeurs is de kwaliteit van het onderwijs te verhogen [...] en het beroep aantrekkelijker te maken." (CPB, 2015) 


\subsection{Vooropleiding instromers lerarenopleidingen}

Figuur 2.3 (leraar basisonderwijs), Figuur 2.4 (leraar vo) en Figuur 2.5 (hbo totaal) laten ontwikkelingen zien in de herkomst van instromers naar opleidingsniveau. Als we de aandacht richten op de herkomst van pabo'ers, dan zien we in de periode 2006-2015 een relatieve afname in de instroom vanuit het mbo. Waar in 2006 nog bijna vier op de tien pabo'ers (38\%) instroomde vanuit het middelbaar beroepsonderwijs, betreft dit in 2015 nog maar een kwart (24\%). Hoewel het aandeel mbo'ers gedurende de gehele periode afneemt, is er met name tussen 2014 (toen het aandeel 35\% betrof) en 2015 sprake van een forse daling. Andersom zien we dat het aandeel havisten en vwo'ers in dezelfde periode (2006-2015) is toegenomen, voor havisten van 47 naar 53 procent en voor vwo'ers van 7 naar 16 procent. Ook hier is met name tussen 2014 en 2015 een fors verschil in het aandeel zichtbaar. Gezien de grote verschillen tussen 2014 en 2015 is het wederom goed denkbaar dat dit te maken heeft met de aanscherping van de vooropleidingseisen.

FIGUUR 2.3 Instroom hbo-opleiding leraar basisonderwijs (voltijd, bachelor) naar vooropleiding, 2006-2015

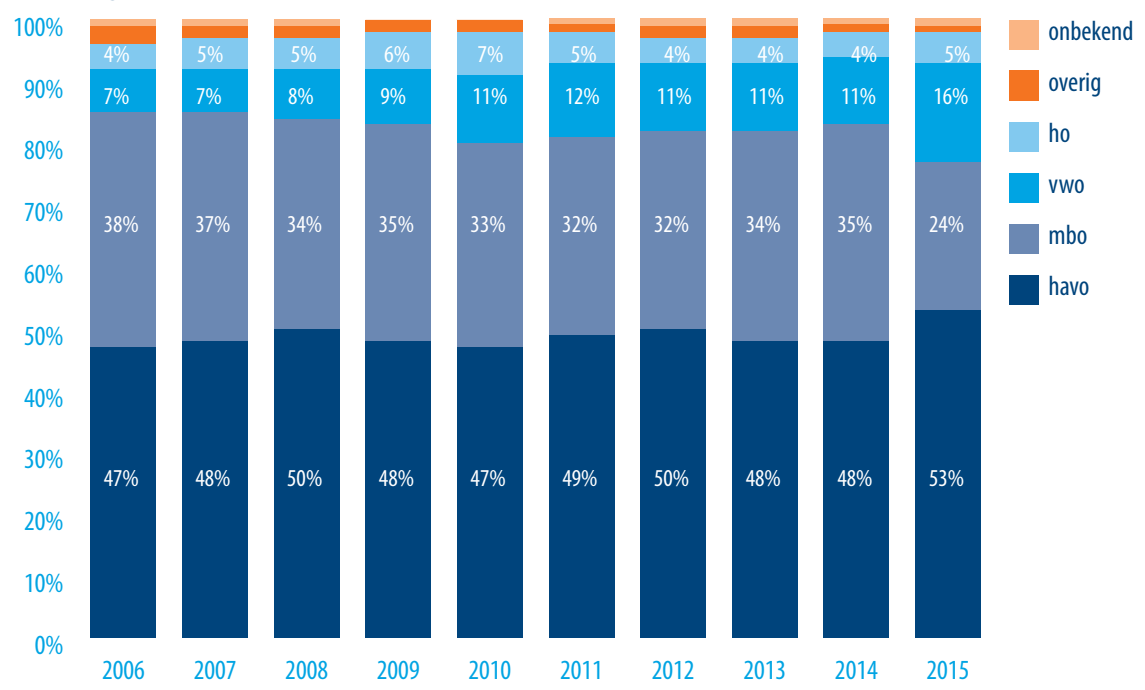

Bron: DUO, 1cijferHO (verkregen via Vereniginghogescholen.nl)

Figuur 2.4 toont de opleidingsherkomst van instromers in de hbo-opleiding voor 'leraar vo'. Omgekeerd zien we aan de pabo een stijging in het aandeel mbo'ers. Waar de instroom in de lerarenopleiding voor het vo in 2006 voor ruim een vijfde (22\%) uit mbo'ers bestond, betreft dit in 2015 meer dan een kwart (26\%). Havisten zijn in de periode 2006-2015 eveneens een (iets) groter instroomaandeel gaan vormen, van 50 naar 53 procent. Instroom vanuit het vwo is in dezelfde periode juist iets afgenomen: van 8 naar 5 procent. De instroom vanuit het hoger onderwijs is in de periode nauwe- 
lijks veranderd, maar ligt hier wel fors hoger (jaarlijks ruim een tiende) dan op de pabo (ongeveer een twintigste).

FIGUUR 2.4 Instroom hbo-opleiding leraar vo (voltijd, bachelor) naar vooropleiding, 2006-2015

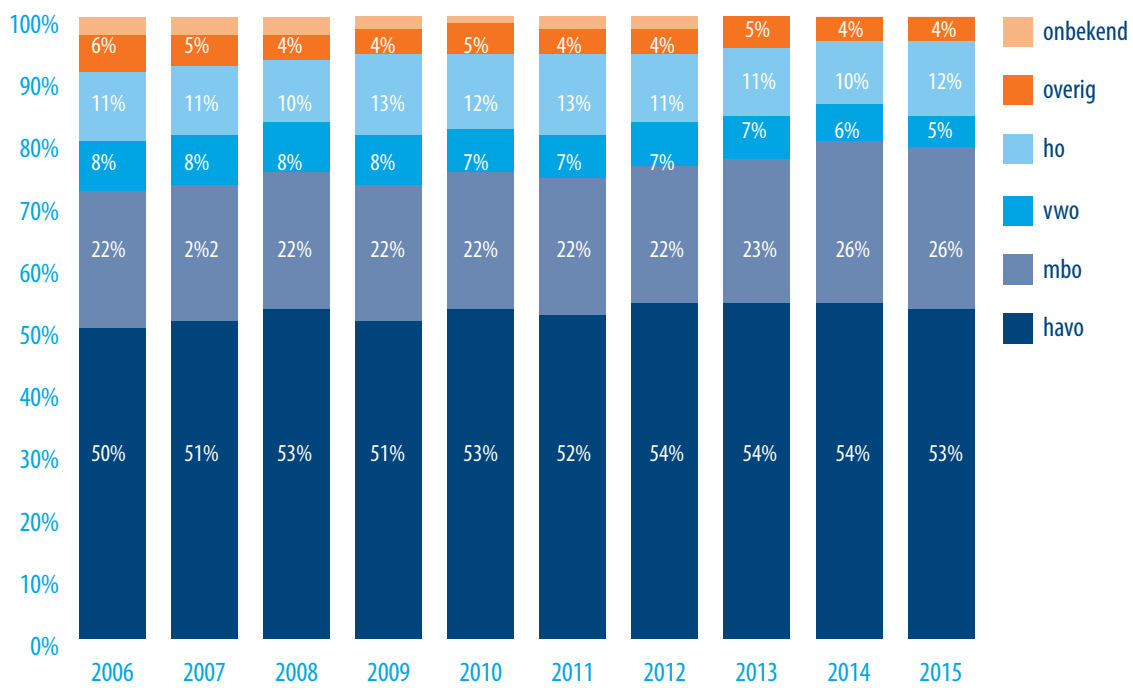

Bron: DUO, 1cijferHO (verkregen via Vereniginghogescholen.nl)

Om de ontwikkelingen uit voorgaande figuren in perspectief te kunnen plaatsen, laat Figuur 2.5 de trend voor het gehele hbo zien. Hieruit volgt dat er tussen 2006 en 2015, in tegenstelling tot de lerarenopleidingen - en met name de pabo - veel minder prominente ontwikkelingen in de opleidingsherkomst te zien zijn. Eén parallel lijkt echter wel te trekken, namelijk het licht groeiende aandeel havisten (van $47 \%$ in 2006 tot $51 \%$ in 2015). Grote verschillen zien we in het kleine aandeel mbo'ers (hbo-totaal) ten opzichte van het aandeel mbo'ers op de pabo (hoewel dit aandeel dus recent fors is geslonken); en in het kleine aandeel ho'ers (hbo-totaal) ten opzichte van de instroom van ho'ers in de opleiding 'leraar vo'.

Voortbouwend op de vorige figuren, zien we op basis van doorstroomcijfers afkomstig van DUO (Figuur 2.6) dat havisten die doorstromen naar het hbo in steeds mindere mate voor de lerarenopleidingen lijken te kiezen. In 2011 betrof de instroom van havo-hbo doorstromers in de sector onderwijs ${ }^{6}$ nog 12,3 procent, in 2015 betrof het ruim 2 procentpunt minder (10,2\%). Het aandeel havisten dat voor een opleiding in de sector onderwijs kiest, ligt in 2015 op het laagste niveau van de afgelopen jaren. Zoals eerder aangegeven zijn hier echter meerdere verklaringen denkbaar

6 De DUO Open Onderwijsdata maken het niet mogelijk om specificaties te maken op lagere niveaus dan de opleidingssector. De hbo-sector 'Onderwijs' wordt vrijwel volledig gevormd door lerarenopleidingen voor het basisonderwijs en het voortgezet onderwijs (zie http://cijfers.vereniginghogescholen.nl/). 
FIGUUR 2.5 Instroom gehele hbo (alle opleidingen voltijd, bachelor) naar vooropleiding, 2006-2015

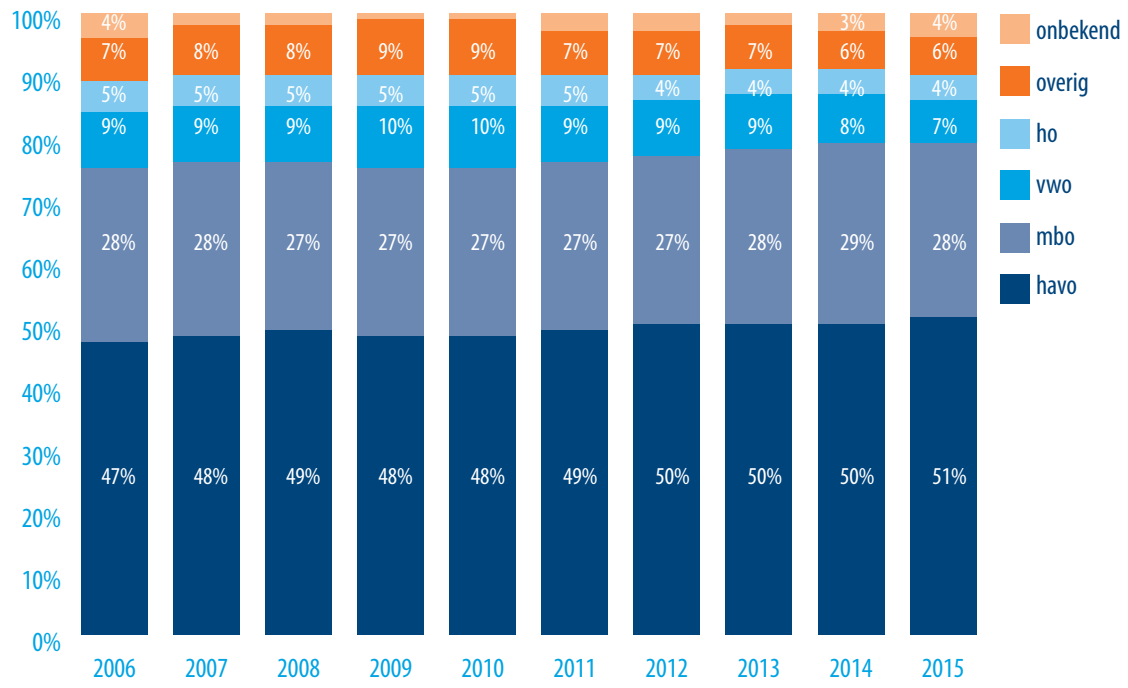

Bron: DUO, 1cijferHO (verkregen via Vereniginghogescholen.nl)

FIGUUR 2.6 Aandeel gediplomeerde havisten dat voor hbo-opleiding in sector onderwijs kiest, als percentage van totaal aantal havisten dat doorstroomt naar hbo, hbo-instroomjaren 2011-2015

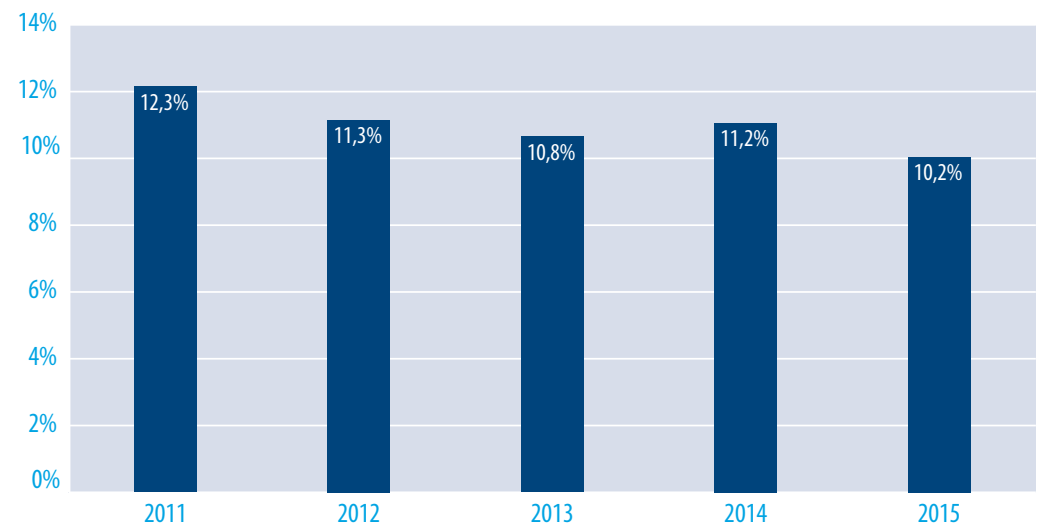

NB: Alleen havisten die in schooljaar direct na examen doorstromen naar hbo Bron: DUO Open Onderwijsdata

\subsection{Eindexamencijfer vooropleiding}

In Figuur 2.7 wordt verder ingezoomd op havisten die doorstromen naar het hbo. Voor de lerarenopleidingen en het hbo-totaal is aan de hand van de VO-Monitor ${ }^{7}$ het gemid-

7 Onderzoek onder schoolverlaters uit het vmbo, havo en vwo, ongeveer anderhalf jaar na het verlaten van de opleiding. 
delde eindexamencijfer van de doorstromers weergegeven. Het percentage havisten met een eindcijfer van 7,5 of hoger ligt bij de lerarenopleiding voor het po gemiddeld iets lager dan bij de lerarenopleiding voor het vo, alsook lager dan bij de andere hboopleidingen. Tegelijkertijd lijkt er in de meest recente examenjaren (2013-2014) sprake van zekere convergentie. Anders gezegd: er lijken momenteel nauwelijks verschillen te bestaan in het aandeel 'topscholieren' dat voor de lerarenopleiding po of vo kiest, dan wel voor andere opleidingen. Wel moeten we gezien de (twee)jaarlijkse fluctuaties en beperkte onderliggende aantallen zeer voorzichtig zijn met deze conclusie.

FIGUUR 2.7 Percentage gediplomeerde havisten met gemiddeld examencijfer van 7,5 of hoger, naar hbo-vervolgopleiding, tweejaarsclusters ${ }^{8}$ examenjaren 1995-2014

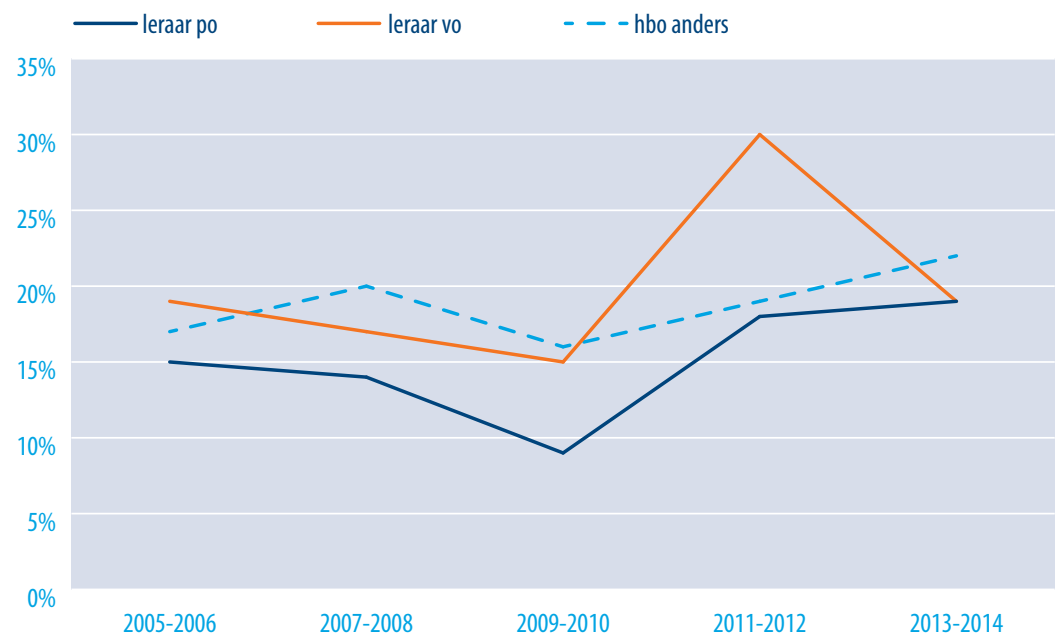

Bron: ROA, VO-Monitor

\subsection{Rendement lerarenopleidingen}

\section{Hbo-bachelors}

Figuur 2.8 toont het percentage hbo-studenten dat na vijf jaar een diploma heeft gehaald, gespecificeerd naar de opleidingen 'leraar basisonderwijs', 'leraar vo' en alle hbo-opleidingen tezamen. De figuur is op diverse manieren interessant. Zo is te zien dat het rendement op de pabo structureel hoger ligt dan het hbo-gemiddelde. Wel zijn de rendementsverschillen tussen pabo en hbo-totaal over de tijd kleiner geworden. Het diplomarendement voor de opleidingen 'leraar vo' liggen juist structureel en fors lager dan gemiddeld, waarbij er bovendien sprake is van divergentie. Wanneer we de ontwikkeling in de 'succespercentages' over de tijd bekijken, dan valt op dat het rendement zowel op de lerarenopleidingen als in het gehele hbo structureel dalende zijn. Het rendement van de opleiding 'leraar basisonderwijs' daalde in de periode 1997-2010 van

8 Vanwege de kleine aantallen per individuele jaargang is er voor gekozen om steeds twee jaargangen tezamen te nemen, 2005-2006; 2007-2008 enz. 
68 naar 53 procent en het rendement van de opleidingen voor 'leraar vo' daalde van 51 naar 33 procent. In het totale hbo ging het om een afname van 58 naar 49 procent. Het rendement is op de lerarenopleidingen derhalve sterker gedaald dan gemiddeld. Hoe dit geïnterpreteerd dient te worden is echter (en wederom) niet eenduidig. Zo is het mogelijk dat de hbo-opleidingen moeilijker zijn geworden, maar kan het ook te maken hebben met de kwaliteit van de opleidingen (bijvoorbeeld minder begeleiding of slechtere curricula) of de kwaliteit van de studenten zelf (bijvoorbeeld minder goed voorbereid door vooropleiding).

FIGUUR 2.8 Aandeel studenten (voltijd, bachelor) dat na 5 jaar diploma heeft gehaald, instroomjaren 1997-2010

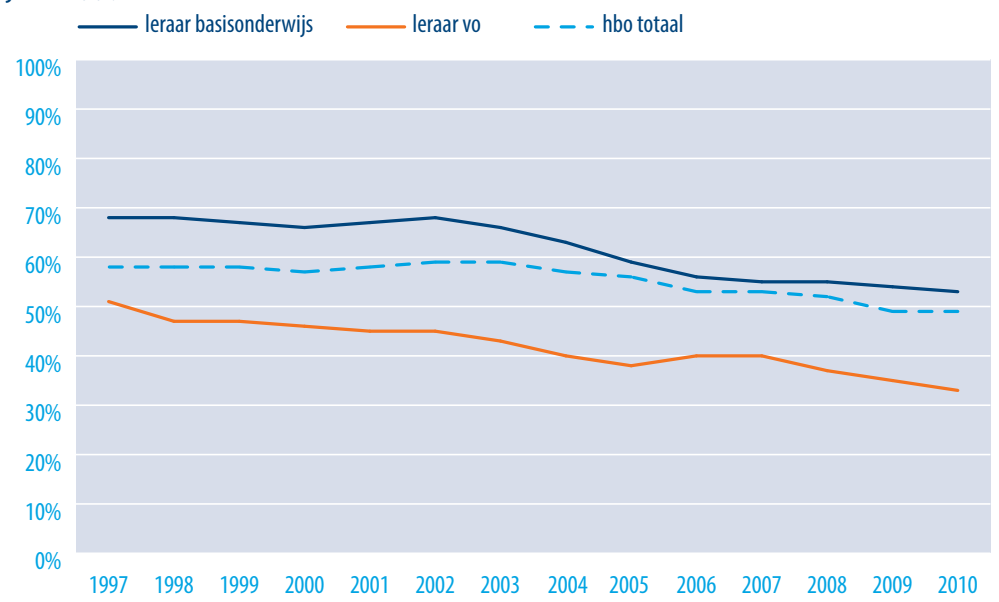

Bron: DUO, 1cijferHO (verkregen via Vereniginghogescholen.nl)

FIGUUR 2.9 Uitvalpercentage hbo-onderwijsmasters (voltijd en deeltijd/duaal), 2002-2014

le graads leraar vo (hbo-master) andere hbo-onderwijsmaster

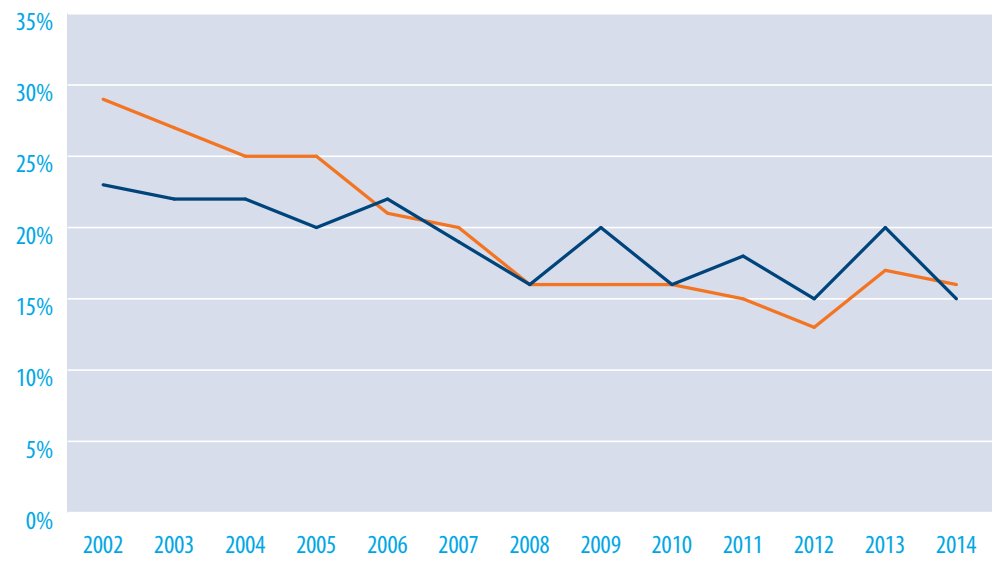

Bron: DUO, 1cijferHO (verkregen via Vereniginghogescholen.nl) 


\section{Hbo-masters}

Waar in voorgaande figuur gekeken werd naar het diplomarendement binnen vijf jaar, toont Figuur 2.9 het jaarlijkse uitvalpercentage (alleen voor de hbo-masters). Rendement in termen van vijf jaar is immers geen zinvolle indicator voor de relatief kortdurende masters. Uit de figuur volgt dat er in de periode 2002-2014 sprake is van een sterke daling in de uitval. Dit in tegenstelling tot de hbo-bachelors uit voorgaande figuur, alwaar een dalend diplomarendement te zien was. Het uitvalpercentage onder studenten aan de eerstgraads hbo-lerarenopleiding nam tussen 2002 en 2014 af met ruim een derde (35\%). Onder studenten aan andere hbo-onderwijsmasters daalde de uitval in deze periode nog sterker (45\%), hoewel de uitval tussen 2012 en 2013 weer iets toenam.

\subsection{Gemiddeld afstudeercijfer lerarenopleidingen}

Afgestudeerden aan de pabo behalen bovengemiddeld vaak een hoog afstudeercijfer ( 8 of hoger), zo volgt uit Figuur 2.10. Aan de lerarenopleidingen voor het vo is het aandeel afgestudeerden met een hoog eindcijfer vrijwel identiek aan het hbo-gemiddelde. Hoewel afgestudeerden aan de opleiding voor 'leraar po' vaker een hoog eindcijfer behalen, neemt dit aandeel in de periode 2002-2014 wel af. Waar in afstudeerjaar 2002 nog 36 procent van de afgestudeerden 'leraar po' gemiddeld een 8 of hoger had, ligt het aandeel in 2014 op 25 procent. Dit ligt nog altijd hoger dan gemiddeld (19\% in 2014), maar de verschillen zijn in de loop van de tijd afgenomen. In hoeverre dit te maken heeft met scherpere afstudeereisen, of met een daling van de kwaliteit van de studenten dan wel de opleiding is moeilijk te zeggen.

FIGUUR 2.10 Aandeel gediplomeerden hbo-lerarenopleidingen (voltijd, bachelor) met gemiddeld afstudeercijfer 8 of hoger, afstudeerjaren 2002-2014

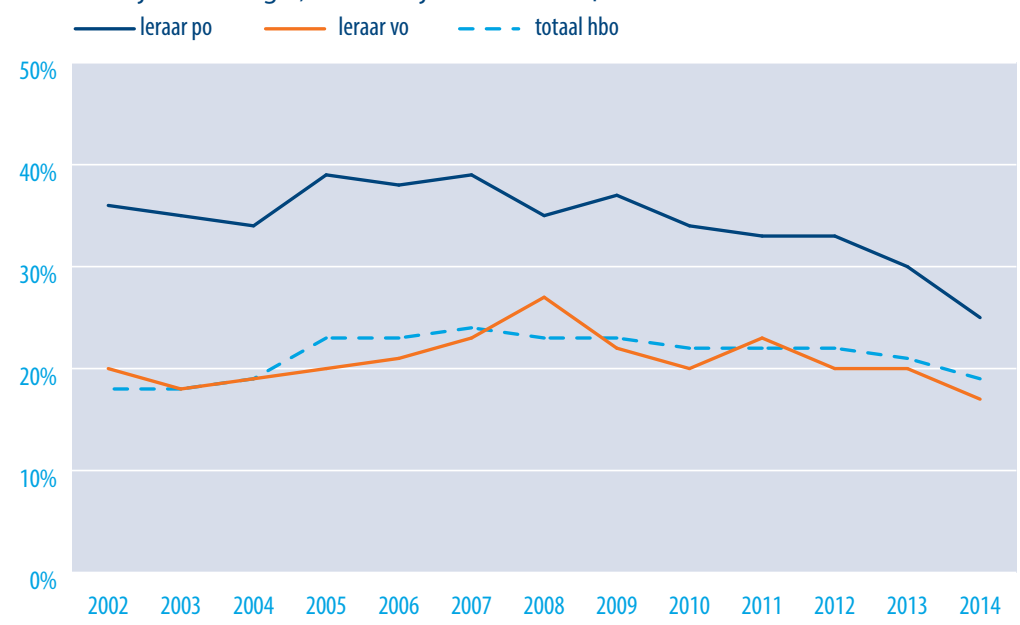

Bron: ROA, HBO-Monitor 


\subsection{Opleidingsniveau beroepsgroep}

Tot slot verschuiven we de aandacht van de lerarenopleiding, naar de opleiding van leraren: oftewel het opleidingsniveau van de beroepsgroep in zijn geheel. Figuur 2.11 toont de ontwikkeling in het gemiddeld opleidingsniveau (GON) ${ }^{9}$ voor drie typen leraren en voor alle Nederlandse beroepsgroepen tezamen. Hieruit volgt dat van de drie typen leraren de 'docenten algemene vakken secundair onderwijs' gemiddeld het hoogst zijn opgeleid. De twee overige lerarengroepen 'docenten beroepsgerichte vakken secundair onderwijs' en 'leerkrachten basisonderwijs' hebben ruwweg een even hoge 'GON' (enige fluctuatie in de laatste jaren daargelaten). De langetermijntrend van het GON voor Nederland als geheel neemt vrijwel structureel toe, terwijl deze voor de groepen leraren vrij stabiel of zelfs licht dalend is. Hoewel leraren gemiddeld genomen dus fors hoger opgeleid zijn dan werkzaam Nederland als geheel, is de relatieve 'voorsprong' tanende. Anders gesteld: de 'exclusiviteit' van leraren als hoogopgeleide beroepsgroep is in de loop der jaren afgenomen.

FIGUUR 2.11 Gemiddeld opleidingsniveau (GON) voor beroepen in sector onderwijs en totaal Nederlandse beroepsgroepen, 1996-2014

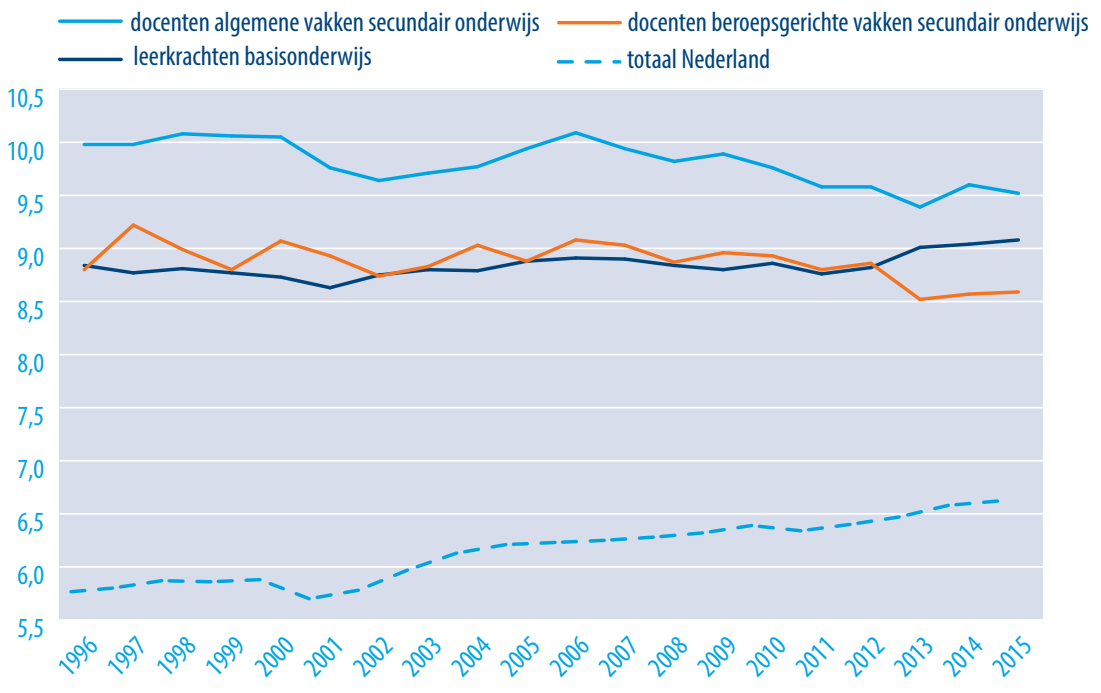

Bron: CBS, Enquête Beroepsbevolking

Uit de voorgaande figuur volgt dat de relatieve 'voorsprong' in opleidingsniveau van leraren ten opzichte van de rest van Nederland afgenomen is. Om dit in perspectief te plaatsen toont Figuur 2.12 de ontwikkeling in het GON voor enkele 'referentieberoepen'. Hoewel dit een vrij diffuus beeld oplevert, lijkt de dalende 'relatieve voorsprong' niet alleen voor leraren te gelden, maar ook voor veel andere (van oudsher) hoogopgeleide

9 Het GON wordt berekend aan de hand van het aantal opleidingsjaren na het basisonderwijs: 3 jaar voor vmbo, 6 jaar voor havo, vwo en mbo, 9 jaar voor hbo en 12 jaar voor wo (Bijlsma et al., 2015). 
beroepen. Het stijgende opleidingsniveau van Nederland als geheel lijkt dus vooral toe schrijven aan opleidingstoename onder de (van oudsher) lager geschoolde beroepen. Vermoedelijk speelt voor de (traditioneel) hogeropgeleide functies zoals leraren een zeker 'plafondeffect' (i.e. weinig 'verbetering' meer mogelijk), hoewel we voor de eveneens hoogopgeleide groep 'onderwijsmanagers' wél een (lichte) verdere stijging in het opleidingsniveau zien.

FIGUUR 2.12 Gemiddeld opleidingsniveau (GON) voor beroepen in sector onderwijs en enkele referentieberoepen, 1996-2014

\begin{tabular}{ll} 
- docenten algemene vakken secundair onderwijs & --- managers onderwijs \\
\hline - docenten beroepsgerichte vakken secundair onderwijs & onderwijskundigen en overige docenten \\
- - l - - docerkrachten basisonderwijs & overheidsambtenaren \\
\hline psychologen en sociologen & leidsters kinderopvang en onderwijsassistenten
\end{tabular}

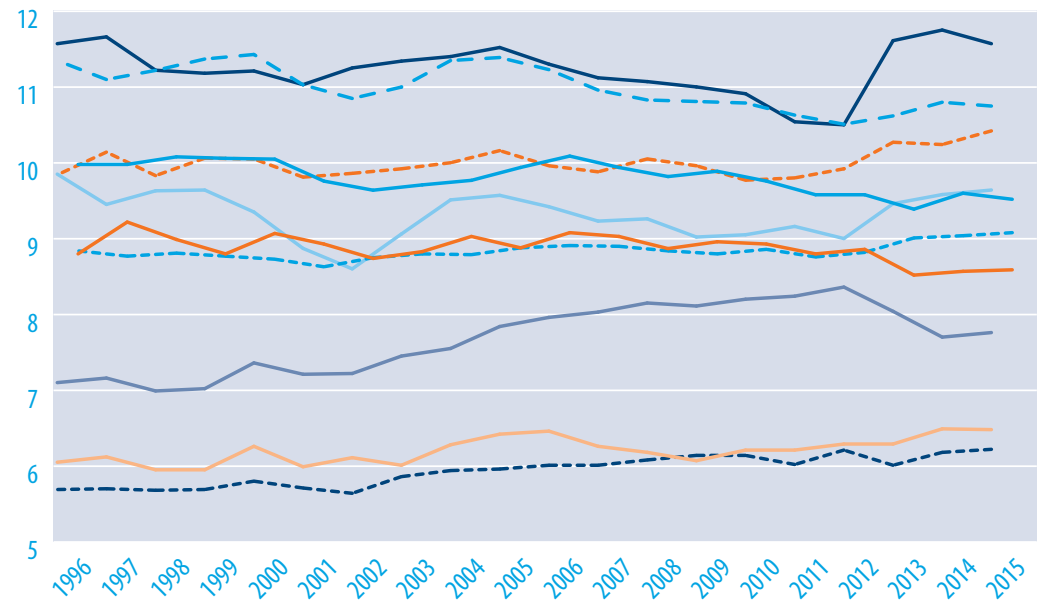

Bron: CBS, Enquête Beroepsbevolking

In de volgende paragrafen verschuiven we de aandacht van (de leraren)opleiding naar de sociale compositie van het lerarenbestand in Nederland. Achtereenvolgens kijken we naar de (ontwikkeling in de) opbouw van het personeelsbestand naar geslacht, leeftijd en etniciteit.

\subsection{Sociale compositie: geslacht}

In alle onderwijssectoren (po, vo, mbo) is sinds 1999 sprake van een vrijwel lineaire toename in het aandeel vrouwelijke leraren (gemeten in personen). Wel zijn er sectorale verschillen. Zo is het primair onderwijs 'van oudsher' een sterk gefeminiseerde (sub)sector, alwaar het aandeel leraressen bijna twee keer zo hoog ligt als in het voortgezet onderwijs en het middelbaar beroepsonderwijs. Ondanks het traditioneel hoge aandeel vrouwen in het po, neemt dit aandeel nog altijd toe: van 77 procent in 1999 
naar 87 procent in 2015. In het voortgezet onderwijs is het aandeel mannen en vrouwen veel gelijkmatiger verdeeld, hoewel ook hier een structurele toename in het aandeel vrouwen zichtbaar is. Zo vormden leraressen in 1999 nog 38 procent van de lerarenformatie, terwijl het in 2015 om 53 procent ging. Deze toename is daarmee het sterker dan in het po en het mbo. Het mbo is in de periode 1999-2015 gemiddeld genomen de onderwijssector met de meest gelijke verdeling van de aandelen mannelijke en vrouwelijke leraren. Ook in deze sector is een groei in het aandeel vrouwen waarneembaar, maar veel minder nadrukkelijk dan in het po en het vo. Het aandeel vrouwen groeide tussen 1999 en 2015 van 46 procent tot 53 procent.

Vergeleken met het percentage vrouwen in de gehele werkzame beroepsbevolking, is het aandeel vrouwen in het onderwijs hoog te noemen. In $2014^{10}$ makten vrouwen 45 procent uit van de totale werkende beroepsbevolking, tegenover respectievelijk 86, 52 en 53 procent van de lerarenformatie in het po, vo en mbo. Hoewel er net als in het onderwijs ook onder de gehele beroepsbevolking een toenemend aandeel werkende vrouwen zichtbaar is, is deze toename in het onderwijs veel sterker.

FIGUUR 2.13 Aandeel vrouwen werkzaam als onderwijzend personeel en als aandeel van totale werkzame beroepsbevolking, in personen, 1999-2015

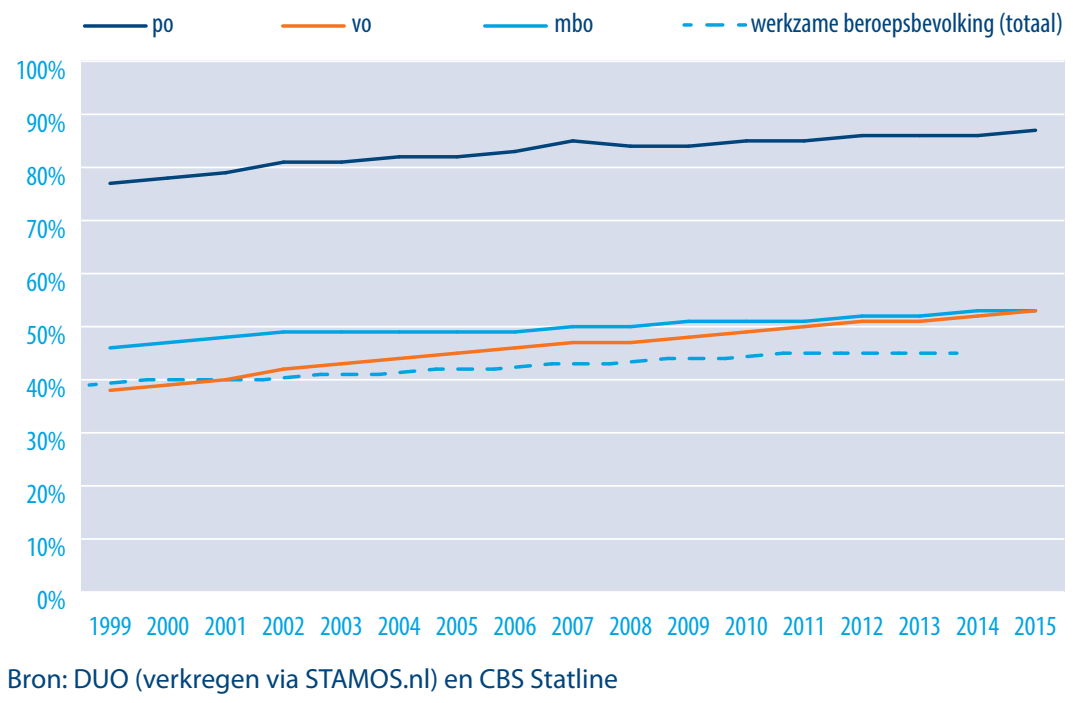

\subsection{Sociale compositie: leeftijd}

In de periode 2008-2015 is het lerarenbestand snel vergrijsd, zo blijkt uit Figuur 2.14. Hoewel verdere vergrijzing sinds 2013 tot een halt lijkt te zijn gekomen, ligt het aandeel 55-plussers in 2015 nog altijd wel op een hoog niveau. De vergrijzing is een onder-

102014 is het meest actuele gegevensjaar over de werkzame beroepsbevolking zoals gepresenteerd op CBS Statline 'Beroepsbevolking; kerncijfers naar geslacht en andere kenmerken'. 
wijsbreed fenomeen, maar is het meest prominent in het mbo. Waar het middelbaar beroepsonderwijs in 2008 voor 32 procent uit 55-plussers bestond, gaat het in $2015 \mathrm{om}$ 39 procent. Ook het po laat in deze periode een toename zien van 7 procentpunt (van $19 \%$ naar 26\%), maar hier ligt het aandeel oudere leraren al jaren fors lager dan in het mbo. Het voortgezet onderwijs laat een minder snel vergrijzingsproces zien (van $25 \%$ in 2008 naar 29\% in 2015), wel ligt het aandeel 55-plussers hier hoger dan in het po.

De ontwikkelingen in het aandeel 55-plussers in de gehele werkzame beroepsbevolking laat een duidelijke vergrijzing zien. In de periode 2008-2014" groeide in Nederland het aandeel werkenden van 55 jaar of ouder van 13 procent naar 17 procent. Wel is deze landelijke toename zwakker dan binnen de beroepsgroep leraren, en ligt dit aandeel bovendien vele male lager. Het percentage 55 -plussers is in het mbo zelfs meer dan twee keer zo hoog als het landelijk gemiddelde.

FIGUUR 2.14 Figuur 2.14 - Aandeel onderwijzend personeel van 55 jaar of ouder (in fte) en aandeel 55 jaar of ouder van totale werkzame beroepsbevolking (in personen), 1999-2015

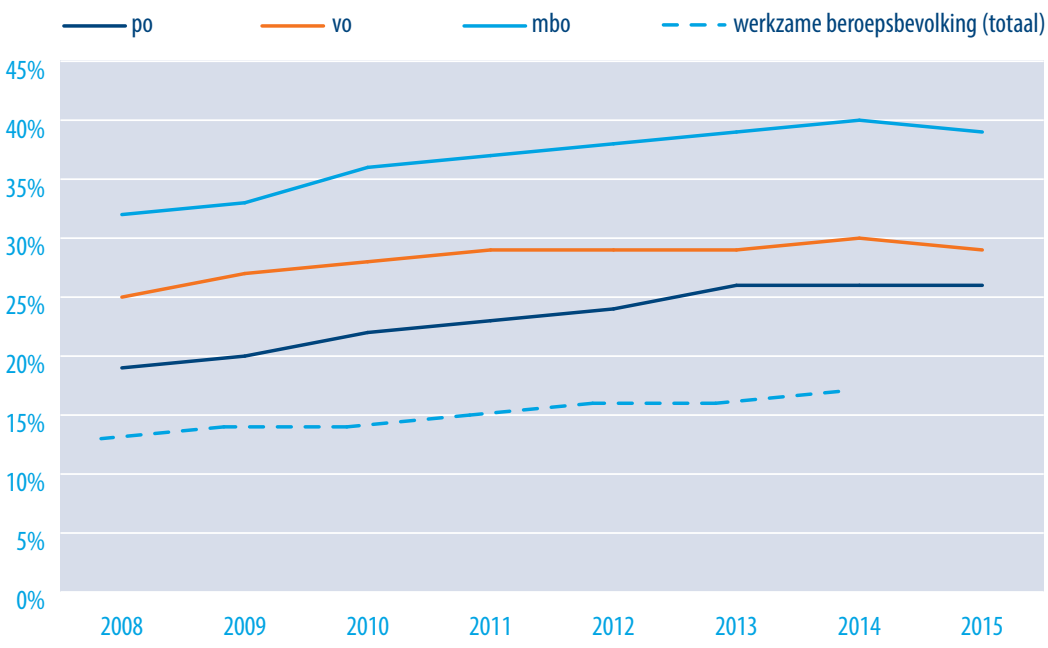

Bron: DUO (Verkregen via STAMOS.nl) en CBS Statline

\subsection{Sociale compositie: etniciteit}

Tot slot kijken we naar de etnische compositie van het onderwijs. Figuur 2.15 toont het aandeel niet-westers allochtonen dat werkzaam is in het po, vo en mbo in de periode 1998-2014 ${ }^{12}$. In het vo en mbo is het aandeel niet-westers allochtonen in deze periode

112014 is het meest actuele gegevensjaar over de werkzame beroepsbevolking zoals gepresenteerd op CBS Statline 'Beroepsbevolking; kerncijfers naar geslacht en andere kenmerken'.

12 Met deze data is het niet mogelijk om leraren te onderscheiden van overig onderwijspersoneel. Hoewel leraren het overgrote merendeel van het onderwijspersoneel uitmaken, kan het zijn dat ontwikkelingen in de etnische compositie deels toe te schrijven zijn aan veranderingen binnen niet-lesgevende functies. 
fors en structureel toegenomen, in beide sectoren met 3,4 procentpunt. In het po is opvallend genoeg geen toename in het aandeel allochtonen te zien, met enige fluctuaties daargelaten is het aandeel over de tijd ruwweg stabiel gebleven. De etnische diversiteit verschilt flink tussen de verschillende onderwijssectoren. In 2014 was het aandeel niet-westerse allochtonen in het mbo het grootst met 6,3 procent, in het vo betrof het 5,4 procent en in het po is het aandeel het kleinst met 3,6 procent.

Vergeleken met het landelijk gemiddelde over alle sectoren, werken er in het onderwijs weinig niet-westerse allochtonen. In de gehele periode 1998-2014 ligt het aandeel allochtonen in het onderwijs ongeveer twee keer zo laag als binnen de gehele werkzame beroepsbevolking. Zo betrof in 2014 het aandeel niet-westerse allochtonen in de gehele beroepsbevolking 9,4 procent, tegenover 4,6 procent in het po, vo en mbo tezamen.

FIGUUR 2.15 Aandeel niet-westerse allochtonen ${ }^{13}$ werkzaam in onderwijs en als aandeel van werkzame beroepsbevolking (in personen), 1998-2014

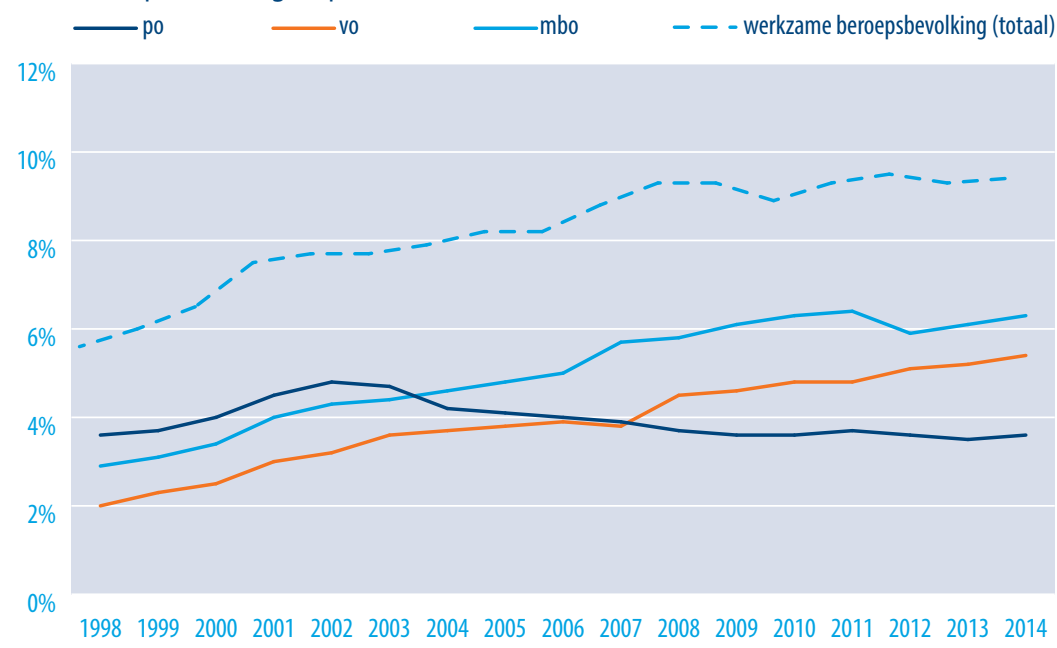

Bron: DiversiteitIndex, Ministerie van BZK (verkregen via arbeidenoverheid.nl) en CBS Statline

\subsection{Reflectie}

\section{Opleiding}

De absolute instroom in de hbo-opleiding leraar vo is de afgelopen tien jaar ruwweg stabiel gebleven. De instroom in de pabo (lerarenopleiding basisonderwijs) is tussen de studiejaren 2006/2007 tot 2015/2016 gehalveerd: van ca. 7.500 tot ca. 3.500. Met name in studiejaar 2015/2016 is de instroom sterk gedaald (met 1.700 inschrijvers), wat samenvalt met een flinke aanscherping van de instroomeisen in dat jaar. Daardoor lijkt het aandeel havo/vwo'ers toegenomen, tegenover een afname van het aandeel mbo'ers. Hoewel

13 Personen van wie minstens één ouder geboren is in: Turkije, Afrika, Azië (met uitzondering van Indonesië, Japan) of Latijns-Amerika. 
de toelatingseisen vooral per 2015/2016 zijn aangescherpt, was in de jaren daarvoor het aandeel pabo-studenten met een vooropleiding van het vwo al toegenomen. Het niveau van de vooropleiding van studenten aan de lerarenopleiding voor het vo neemt daarentegen af: meer mbo'ers en minder vwo'ers.

Waar de instroom in de tweedegraads lerarenopleidingen relatief stabiel is gebleven, is er een toename van het aantal inschrijvingen eerstegraads opleidingen. Zowel de universitaire lerarenopleidingen (ulo) als de eerstegraads lerarenopleidingen van het hbo laten sinds 2008 een groei zien in het aantal ingeschreven studenten. Tegelijkertijd is er juist een flinke afname in het aantal inschrijvingen in de overige hbo-onderwijsmasters (vooral de master 'educational needs'). Dit laatste hangt samen met de afname van de aanvragen voor de Lerarenbeurs.

Andere indicatoren die verband houden met de selectie aan lerarenopleidingen zijn onder meer een afname van het diplomarendement na vijf jaar onder de tweedegraads lerarenopleidingen en een kleiner aandeel van afgestudeerden met een gemiddeld eindcijfer 8 of hoger. Deze trends zijn echter niet eenvoudig te interpreteren, ook omdat dezelfde trends bij veel andere hbo-opleidingen zichtbaar zijn. Het opleidingsniveau van de gehele beroepsgroep leraren is zeer hoog. In die zin is het beroep van leraar als 'statusrijk' te kwalificeren. De langetermijntrend van het opleidingsniveau van de Nederlandse bevolking is echter positief, terwijl deze voor de beroepsgroep leraren vrij stabiel is. De 'exclusiviteit' van leraren als hoogopgeleide beroepsgroep is dus in de loop der jaren afgenomen.

\section{Sociale compositie}

Het onderwijs kent al vijftien jaar een sterke toename in het aandeel vrouwelijke leraren. Van oudsher is het po de sterkst gefeminiseerde sector: in 2015 was bijna negen op de tien leraren vrouw. Dit aandeel is bijna twee keer zo hoog als in de totale Nederlandse werkzame beroepsbevolking. Het onderwijs is tevens een snel vergrijzende sector. Hoewel dit een landelijk fenomeen is, gaat dit proces bij de leraren veel sneller. Zo is het aandeel 55-plussers in het onderwijs veel hoger dan in andere sectoren: in het vo met ongeveer 30 procent bijna twee keer zo hoog. Onder de leraren in het mbo is het aandeel 55-plussers zelfs bijna 40 procent. Tot slot blijkt de etnische diversiteit in het vo en mbo toe te nemen tussen 1998 en 2014, hoewel de diversiteit nog steeds betrekkelijk laag is. Het aandeel niet-westerse allochtonen in het vo en mbo is met respectievelijk 5 en 6 procent in 2014 veel lager dan het landelijke aandeel van 9 procent. In het po is de diversiteit na 2002 afgenomen en heeft nog geen 4 procent van de leraren een nietwesterse herkomst. 



\section{STATUS: INDICATOREN ARBEIDSMARKT}

\subsection{Inleiding}

In dit hoofdstuk worden diverse trends in de arbeidsmarktpositie van leraren gepresenteerd die indicatief kunnen zijn voor de beroepsstatus. We kijken vooral naar de positie van recent afgestudeerden van de lerarenopleidingen, aangezien ontwikkelingen in de arbeidsmarktpositie van leraren met name (snel) zichtbaar zullen zijn bij de groep'starters'. Arbeidsmarktontwikkelingen binnen de beroepsgroep als geheel zullen zich naar verwachting veelal wat gematigder voordoen. In dit hoofdstuk is onder meer aandacht voor werkloosheid, de mate waarin afgestudeerden in het onderwijs terecht komen, alsook voor de beloningsontwikkelingen.

Overeenkomstig hoofdstuk 2 richten we de blik vooral op afgestudeerde leraren van hbo-bacheloropleidingen. Hoewel we, waar mogelijk, ook naar afgestudeerden van de hbo-onderwijsmasters en ulo's kijken, zijn deze groepen afgestudeerden minder goed vergelijkbaar met hbo-bachelors. Waar het bij de bacheloropleidingen 'pabo' en 'leraar vo' gaat om reguliere opleidingen, zijn de hbo-onderwijsmasters en de ulo aanvullende opleidingen waarvoor doorgaans al een hbo- of wo-vooropleiding benodigd is. Bij de hbo-onderwijsmasters gaat het bovendien vaak om studerenden die reeds als leraar werkzaam zijn.

\subsection{Werkloosheid onder recent afgestudeerden}

\section{Hbo-bachelors}

Figuur 3.1 toont de werkloosheidsontwikkeling voor hbo-afgestudeerden van de pabo, voor hbo-afgestudeerden van de lerarenopleidingen van het vo en voor afgestudeerden van het hbo als geheel. Door de invloed van de conjunctuur is er sprake van flinke schommelingen over de jaren heen. Ruwweg zien we dezelfde golfbewegingen bij de lerarenopleidingen als bij het totaal van hbo-afgestudeerden. Wel ligt het werkloosheidspercentage onder afgestudeerden aan de opleiding 'leraar vo' sinds het afstudeerjaar 2002 structureel (en vaak meerdere procentpunten) lager dan gemiddeld. De ontwikkeling in de werkloosheid onder afgestudeerden aan de pabo ('leraar po') is veel grilliger en kent diverse uitschieters, waarbij met name in de periode 2010-2014 grote fluctuaties optreden. In de meest recente meting (afstudeerjaar 2014) ligt de werkloos- 
heid op hetzelfde niveau als die onder afgestudeerden aan de lerarenopleiding vo, en daarmee lager dan het gemiddelde voor het hele hbo.

FIGUUR 3.1 Werkloosheidspercentage afgestudeerden hbo-lerarenopleidingen (voltijd, bachelor), anderhalf jaar na afstuderen, afstudeerjaren 1995-2014

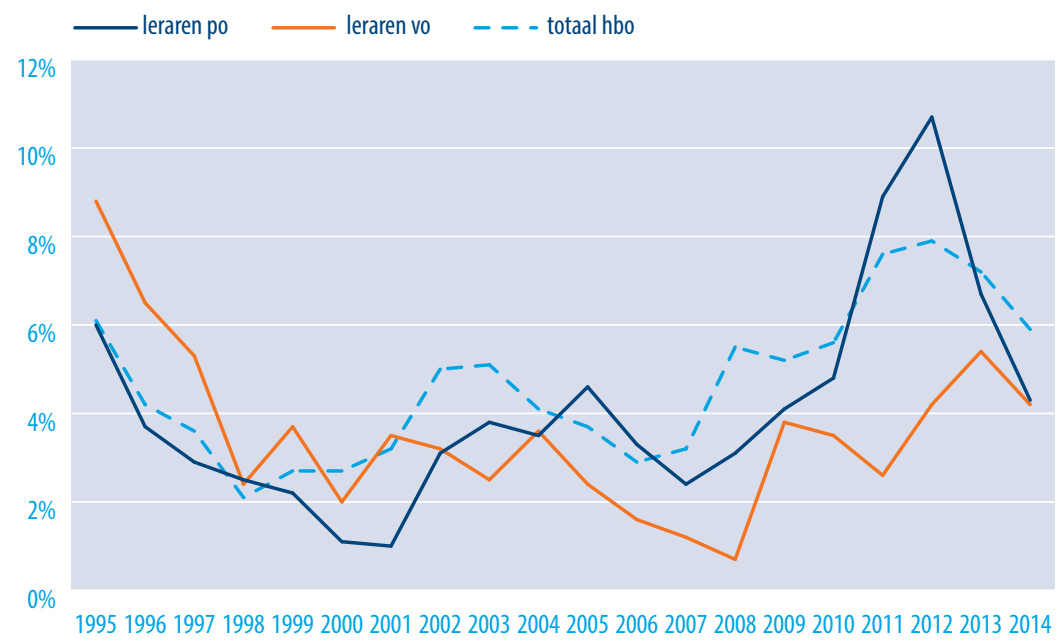

Bron: ROA, HBO-Monitor

\section{Hbo-masters en universitaire lerarenopleidingen}

De werkloosheid onder afgestudeerden aan de hbo-masters ligt relatief laag: sinds 2009 kwam het werkloosheidspercentage zelfs niet boven de 2 procent. De lage werkloosheid zal voor een groot deel te maken hebben met het type studenten dat een hbo-master volgt. Het betreft hier immers in een zeer grote mate deeltijd- en duale studenten ${ }^{14}$ die hun opleiding veelal combineren met een baan. In die zin is de hogere werkloosheid tussen 2006 en 2008 enigszins opvallend te noemen.

Bij de ulo gaat het vaker om doorstromers die na hun behaalde wo-bachelor of wo-master een lerarenopleiding volgen. Dit wordt ook grotendeels weerspiegeld in de werkloosheidscijfers: deze zijn vanaf 2010 vele malen hoger dan bij de hbo-masters. De werkloosheid onder ulo-afgestudeerden nam tussen 2008 en 2012 bijna lineair toe van o procent tot 10 procent. Tussen 2012 en 2014 nam de werkloosheid weer snel af tot 5 procent. Deze golfbeweging is sterk in lijn met de bevinding uit de vorige figuur; daar zagen we dat de werkloosheid onder afgestudeerde hbo-bachelors uit 2012 hoog was.

14 In 2015 bestond zelfs 98 procent van de inschrijvingen aan hbo-onderwijsmasters uit deeltijd en duale studenten. 
FIGUUR 3.2 Werkloosheidspercentage hbo-onderwijsmasters en universitaire lerarenopleidingen (voltijd en deeltijd/duaal), anderhalf jaar na afstuderen, afstudeerjaren 2007-2014

1e graads leraar vo (hbo-master) andere hbo-onderwijsmaster universitaire lerarenopleiding

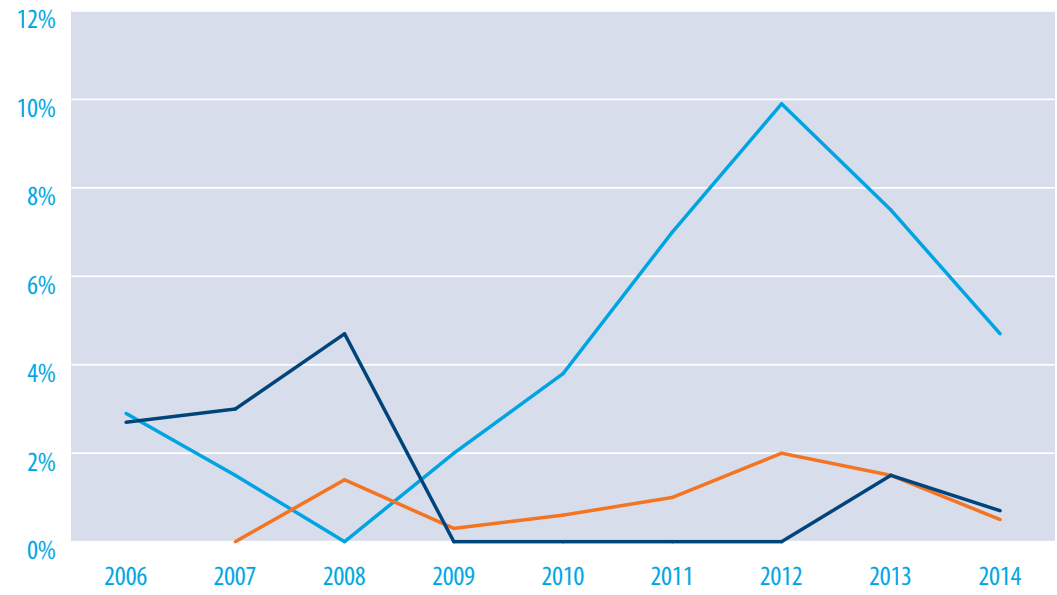

NB: de WO-Monitor / Nationale Alumni Enquête is een tweejaarlijkse studie, de getoonde cijfers hebben betrekking op afgestudeerden uit de 'even' jaren.

Bron: ROA, HBO-Monitor; VSNU, WO-Monitor / Nationale Alumni Enquête

\subsection{Huidige sector afgestudeerden lerarenopleiding}

Pabo'ers die anderhalf jaar na afstuderen een baan hebben, werken vrijwel altijd in de onderwijssector ${ }^{15}$, zo volgt uit Figuur $3.3^{16}$. De inhoudelijke aansluiting tussen opleiding en beroep kan voor de lerarenopleidingen dus als (zeer) goed beschouwd worden. In de periode (van afstudeerjaren) 1995-2014 fluctueert het percentage werkzame pabo'ers dat in de onderwijssector actief is tussen 87 procent (in 2012) en 97 procent (in 1996 en 2001). Bij de vo-lerarenopleidingen ligt het aandeel werkzame afgestudeerden dat werkzaam is binnen het onderwijs structureel lager. In de periode 2002-2014 schommelt het percentage tussen 78 procent (in 2012) en 89 procent (in 2003). Mogelijk speelt hier mee dat afgestudeerden van de vo-lerarenopleidingen meer alternatieve opties hebben in sectoren buiten het onderwijs (meer uitwijkmogelijkheden, zie CPB, 2013 en Cörvers, 2014a). Bovendien is het percentage afgestudeerden van de vo-lerarenopleidingen dat binnen het onderwijs werkzaam is opvallend laag tussen 1995 en 2001, hetgeen wijst op een slechte arbeidsmarktpositie voor veel afgestudeerden van deze opleidingen in die periode. Tussen 1995 en 2002 stijgt het percentage afgestudeerden van vo-lerarenopleidingen dat werkzaam is binnen het onderwijs van 36 naar 87 procent, wat toe te

15 Hoewel afgestudeerde leraren met een baan in het onderwijs niet per definitie een lesgevende functie hebben, kunnen we voor deze groep in ieder geval stellen dat er op sectoraal niveau sprake is van een 'match' tussen opleiding en arbeidsmarkt.

16 Onder 'werkzaam' wordt in de volgende figuren van deze paragraaf verstaan: de werkzame beroepsbevolking exclusief studenten en personen die minder dan 12 uur per week werken. 
schrijven is aan een sterke verbetering van de arbeidsmarktpositie voor deze lerarenopleidingen.

FIGUUR 3.3 Aandeel werkzame afgestudeerden hbo-lerarenopleiding (voltijd, bachelor) dat anderhalf jaar na afstuderen werkzaam is in sector onderwijs; afstudeerjaren 1995-2014

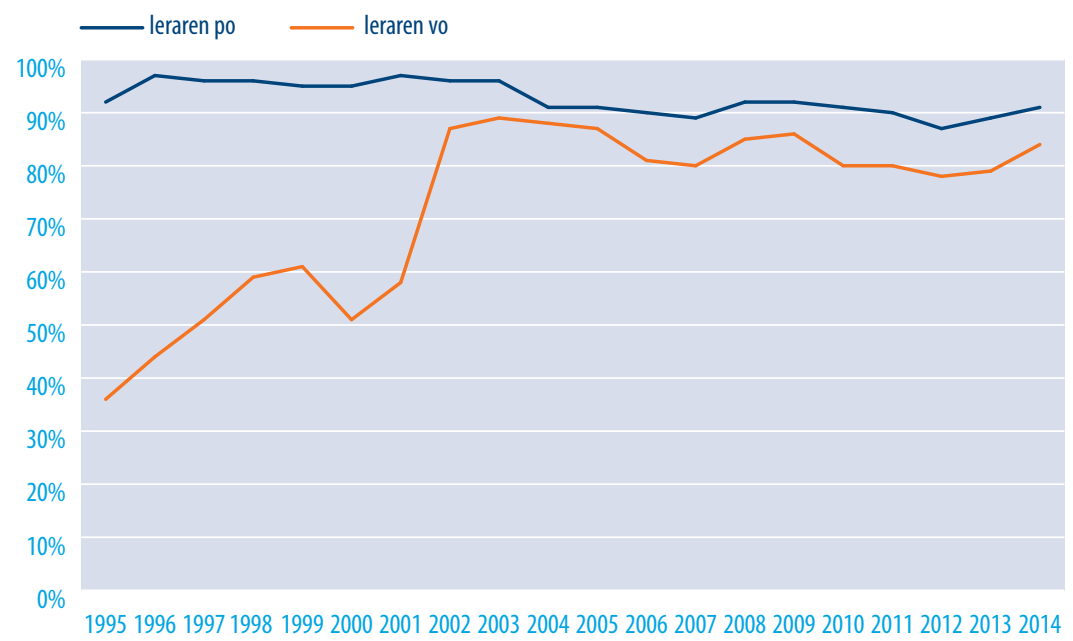

Bron: ROA, HBO-Monitor

Figuur 3.4 laat wederom het percentage afgestudeerden van lerarenopleidingen dat werkzaam is binnen het onderwijs zien, maar nu gespecificeerd naar het gemiddelde afstudeercijfer voor de periode vanaf 2003. We zien zowel voor de po- als vo-lerarenopleidingen dat er een positieve relatie bestaat tussen het afstudeercijfer en de kans dat de afgestudeerde in het onderwijs werkt. Oftewel: de 'beste' afgestudeerden (eindcijfer 8 of hoger) lijken vaker voor de klas komen te staan dan de rest.

\section{Hbo-masters}

Afgestudeerden aan hbo-onderwijsmasters die een baan hebben, werken vrijwel altijd in het onderwijs (Figuur 3.5). Dit geldt zowel voor afgestudeerden van de eerstegraads opleidingen, als voor afgestudeerden van andere onderwijsmasters. Voor deze laatste groep afgestudeerden wijkt alleen afstudeerjaar 2007 af, onder hen werkte 85 procent anderhalf jaar na diplomering in het onderwijs. In alle overige jaren had (onder beide typen hbo-masters) bijna 100 procent van de werkenden een baan in het onderwijs. Zoals reeds aangegeven, komt dit waarschijnlijk doordat studenten aan hbo-onderwijsmasters in sterke mate deeltijd- en duale opleidingen volgen. Zij zullen veelal hun baan in het onderwijs combineren met een opleiding. 
FIGUUR 3.4 Aandeel werkzame afgestudeerden hbo-lerarenopleiding (voltijd, bachelor) dat anderhalf jaar na afstuderen werkzaam is in sector onderwijs, naar gemiddeld afstudeercijfer; tweejaarsclusters van afstudeerjaren 2003-2014

- leraar po: 8 of hoger

— leraar vo: 8 of hoger

_ - - leraar po: lager dan 8

- - - leraar vo: lager dan 8

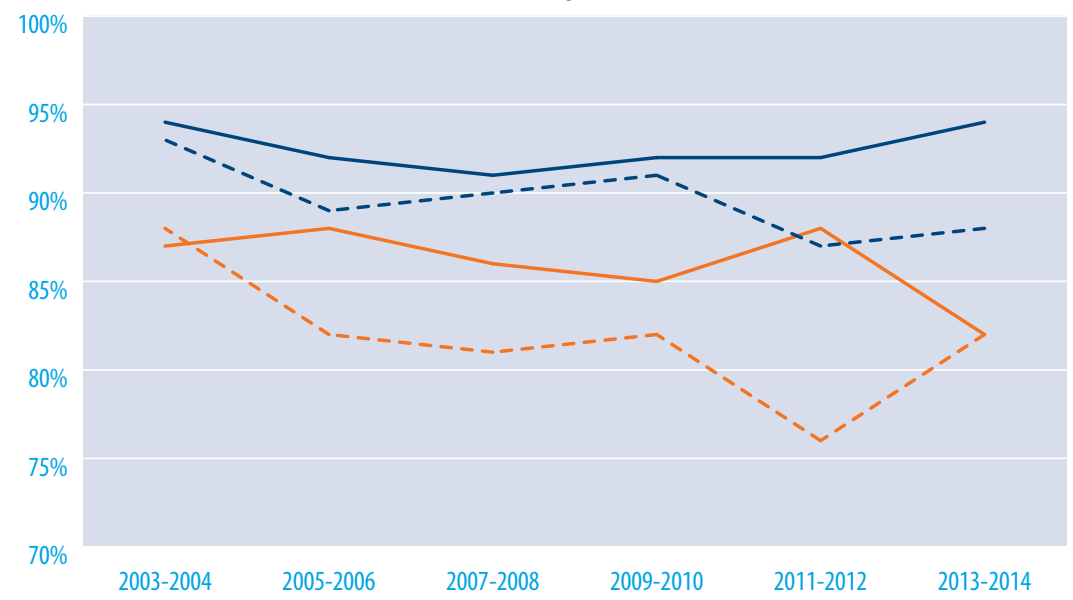

Bron: ROA, HBO-Monitor

FIGUUR 3.5 Aandeel werkzame afgestudeerden hbo-onderwijsmasters (voltijd en deeltijd/duaal) dat anderhalf jaar na afstuderen werkzaam is in sector onderwijs, afstudeerjaren 2007-2014

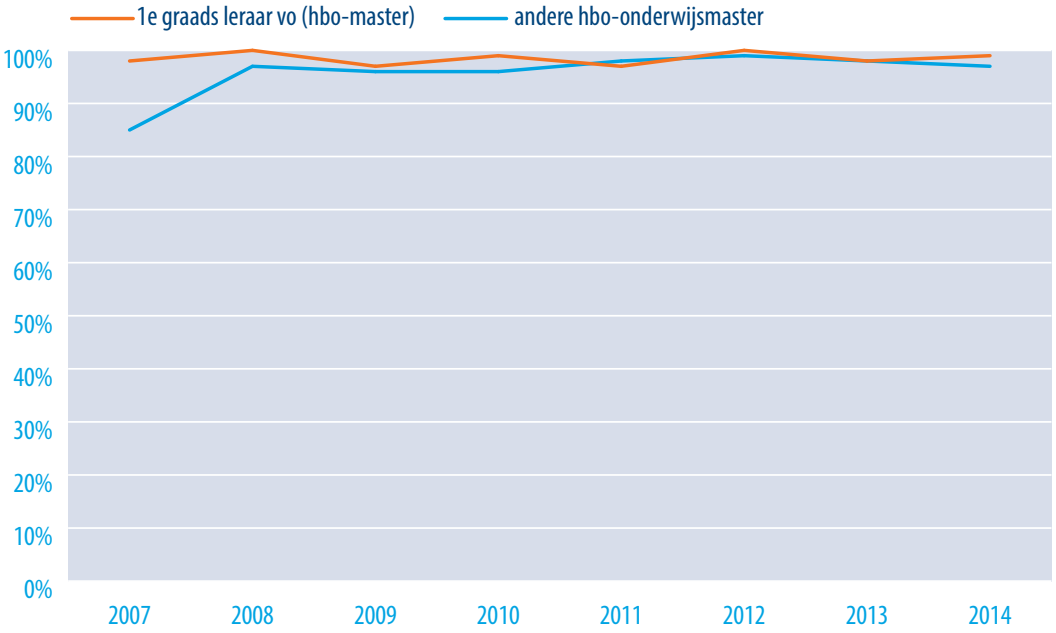

Bron: ROA, HBO-Monitor 
Om inzicht te krijgen in de universitaire lerarenopleiding kunnen we gebruik maken van de jaarlijkse Loopbaanmonitor onderwijs. Deze monitor heeft betrekking op een ander peilmoment dan de HBO-Monitor, waardoor beide niet één op één zijn te vergelijken ${ }^{17}$. Figuur 3.6 toont het aandeel afgestudeerden van de ulo dat een jaar na afstuderen in het onderwijs werkt. Dit aandeel blijkt over de tijd relatief stabiel, ongeveer 80 procent. Afgestudeerden uit 2007 waren iets minder vaak werkzaam in het onderwijs (76\%). Naast percentages voor de ulo toont de figuur ook de percentages voor afgestudeerden aan de pabo en de tweedegraads lerarenopleiding. We zien dat afgestudeerden van de pabo het vaakst in het onderwijs werken, maar dat er vanaf 2010 nauwelijks nog verschil bestaat met de afgestudeerden aan de ulo. Afgestudeerden van de tweedegraads lerarenopleiding werken structureel minder vaak in het onderwijs.

FIGUUR 3.6 Aandeel van de werkzame afgestudeerden dat (mede) werkzaam is binnen het onderwijs, één jaar na afstuderen; afstudeerjaren 2006-201318

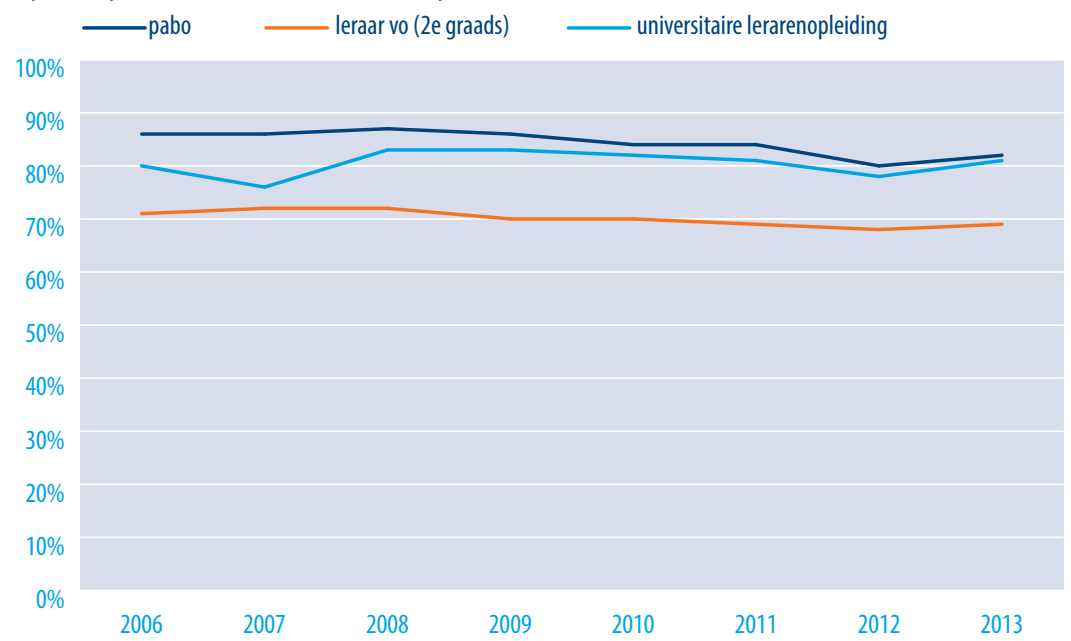

Bron: Loopbaanmonitor onderwijs (2016)

\subsection{Niveau baan recent afgestudeerden}

Figuur 3.7 toont het aandeel werkzame hbo-afgestudeerden dat werkt op hbo/ wo-niveau, gespecificeerd voor de lerarenopleidingen en het hbo als totaal. We zien dat afgestudeerde, werkende pabo'ers vrijwel altijd een baan op hbo/wo-niveau hebben, waarbij dit percentage structureel en fors hoger ligt dan gemiddeld. Ook bij de afgestudeerden van de vo-lerarenopleidingen ligt het percentage dat een functie op hbo/ wo-niveau heeft sinds afstudeerjaar 2002 structureel hoger dan gemiddeld. Vóór 2002

17 Bovendien wordt in de Loopbaanmonitor gebruik gemaakt van CBS-registerdata, daar waar de HBO-Monitor gebaseerd is op enquêtegegevens.

18 De figuur betreft een bewerking van tabellen 2.1 en 2.3 uit het rapport Loopbaanmonitor onderwijs (CentERdata \& MOOZ, 2016). 
lagen de percentages rondom het hbo-gemiddelde, wat wederom wijst op een significante verbetering van de arbeidsmarktpositie van afgestudeerden van de lerarenopleidingen van het vo sinds 2002. In de meest recente meting (afstudeerjaar 2014) heeft negen op de tien afgestudeerde leraren (zowel po als vo) een baan op het eigen werk-/ denkniveau, tegenover bijna acht op de tien in het hbo als geheel.

FIGUUR 3.7 Aandeel werkzame afgestudeerden hbo-lerarenopleiding (voltijd, bachelor) dat anderhalf jaar na afstuderen baan heeft op hbo/wo-niveau; afstudeerjaren 1995-2014

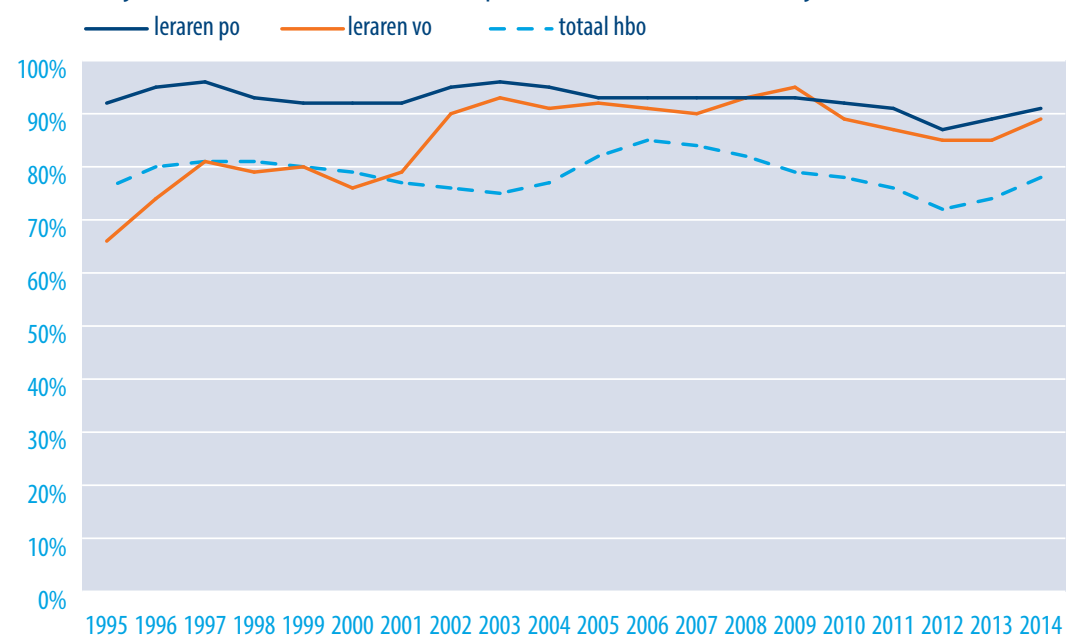

Bron: ROA, HBO-Monitor

Figuur 3.8 laat zien in hoeverre hbo-afgestudeerden van lerarenopleidingen op hbo/ wo-niveau werken, verbijzonderd naar de sector waarin zij werkzaam zijn. Zowel voor afgestudeerde leraren po als vo, zien we dat wanneer zij in het onderwijs werken, zij ook vrijwel altijd een baan op hbo/wo-niveau hebben. Een baan in het onderwijs biedt afgestudeerde leraren dus haast een 'garantie' op een baan op niveau. Afgestudeerde leraren met een baan buiten het onderwijs werken veel minder vaak op het eigen werk-/denkniveau. Dit geldt voor afgestudeerde pabo'ers doorgaans nog sterker dan voor afgestudeerden aan vo-lerarenopleidingen. 
FIGUUR 3.8 Aandeel werkzame afgestudeerden hbo-lerarenopleiding (voltijd, bachelor) dat anderhalf jaar na afstuderen baan heeft op hbo/wo-niveau, naar sector waar men werkzaam is; afstudeerjaren 1995-2014

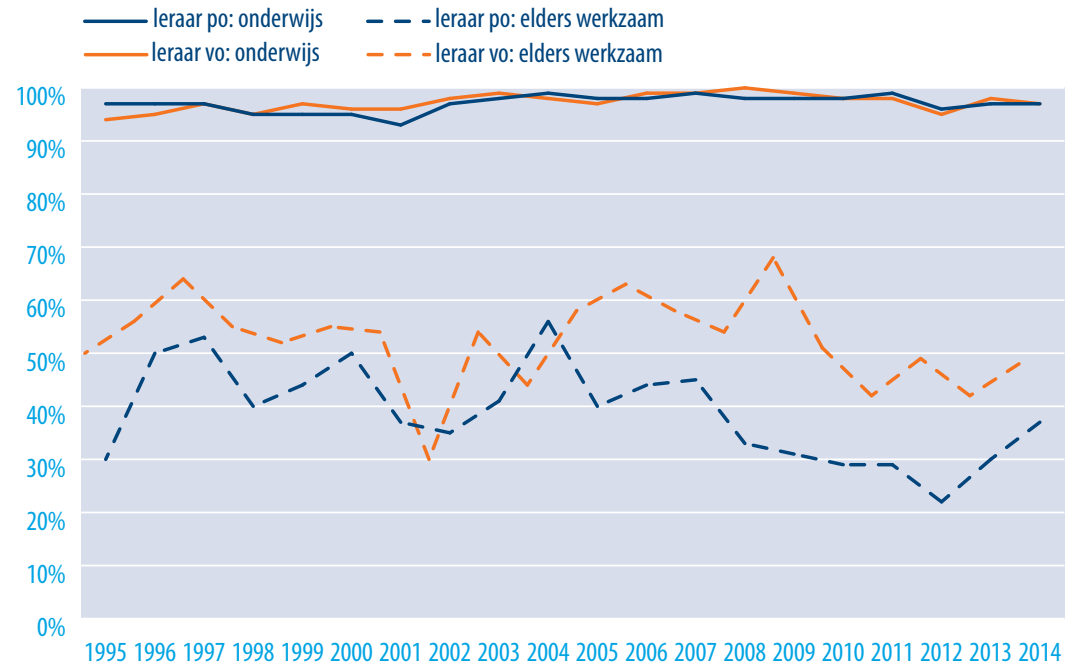

Bron: ROA, HBO-Monitor

\subsection{Dienstverband recent afgestudeerden}

\section{Hbo-bachelors}

In Figuur 3.9 is voor de afstudeerjaren 1995-2014 te zien welk aandeel van de (werkende) afgestudeerden beschikt over een vast dienstverband. Onder de recent afgestudeerden aan de pabo is een toename in het percentage vaste contracten te zien tussen 1995 (45\%) en 2001 (83\%). Deze toename wordt gevolgd door een hele grote daling. Onder de afgestudeerden uit 2014 had slechts 21 procent anderhalf jaar na afstuderen een vaste aanstelling. Bij afgestudeerden aan de vo-lerarenopleidingen zien we ruwweg eenzelfde golfbeweging, zij het iets minder prominent. Ook bij deze groep groeide het percentage afgestudeerden met een vast contract aanvankelijk (ruwweg tot 2003), gevolgd door een vrijwel continue daling. Hadden deze werkzame afgestudeerden uit 2003 anderhalf jaar na afstuderen voor ongeveer driekwart een vast contract, bij het cohort uit 2014 was dat nog maar voor viertiende het geval. Deze golfbewegingen blijken ook bij de gehele afgestudeerdenpopulatie uit het hbo zichtbaar, maar de daling in het aandeel vaste contracten bij pabo'ers is relatief veel sterker, terwijl de daling onder afgestudeerde vo-leraren ten opzichte van het hbo-totaal relatief beperkt is. 
FIGUUR 3.9 Aandeel werkzame afgestudeerden hbo-lerarenopleidingen (voltijd, bachelor) met vast dienstverband, anderhalf jaar na afstuderen; afstudeerjaren 1995-2014

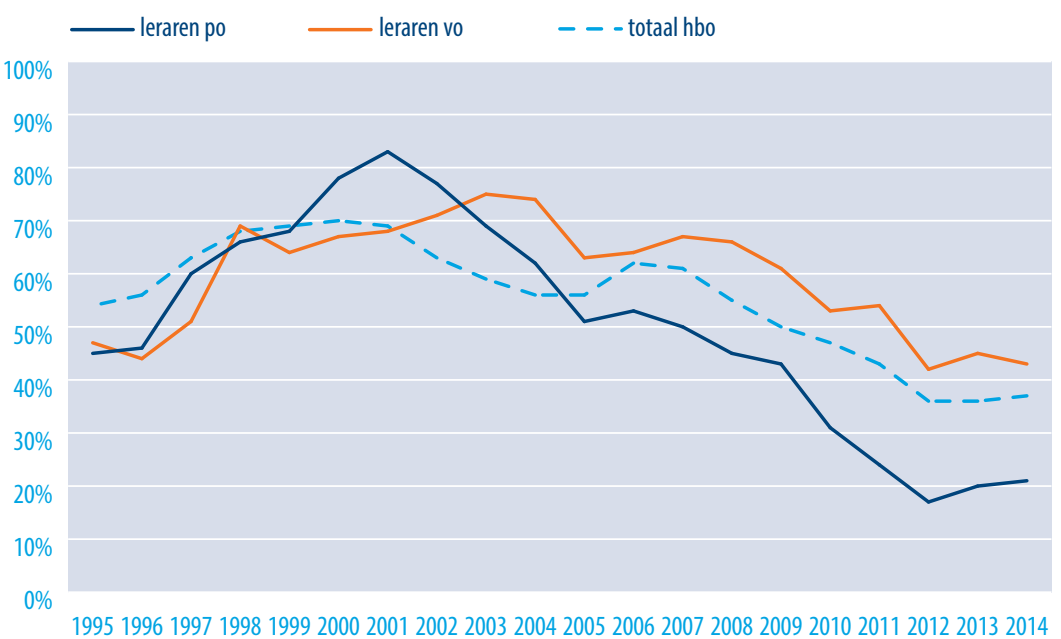

Bron: ROA, HBO-Monitor

\section{Hbo-masters}

De cijfers over afgestudeerde hbo-onderwijsmasters tonen een geheel ander beeld, zo blijkt uit Figuur 3.10. In de periode 2007-2014 ligt het aandeel vaste contracten zowel voor de afgestudeerden aan de eerstegraads lerarenopleiding als voor de andere hbomasters zeer hoog. Voor beide type opleidingen ligt het percentage vaste dienstverbanden namelijk rond de 90 procent. Dit hoge aandeel treffen we, enkele kleine schommelingen daargelaten, in alle jaren aan. Dit grote verschil met de afgestudeerden aan de hbo-bachelor lerarenopleidingen kan wederom verklaard worden door het type studenten dat hbo-masters volgt. Veelal gaat het hier om leraren die naast hun baan een masteropleiding volgen. 
FIGUUR 3.10 Aandeel werkzame afgestudeerden hbo-onderwijsmasters (voltijd en deeltijd/duaal) met vast dienstverband, anderhalf jaar na afstuderen; afstudeerjaren 2007-2014

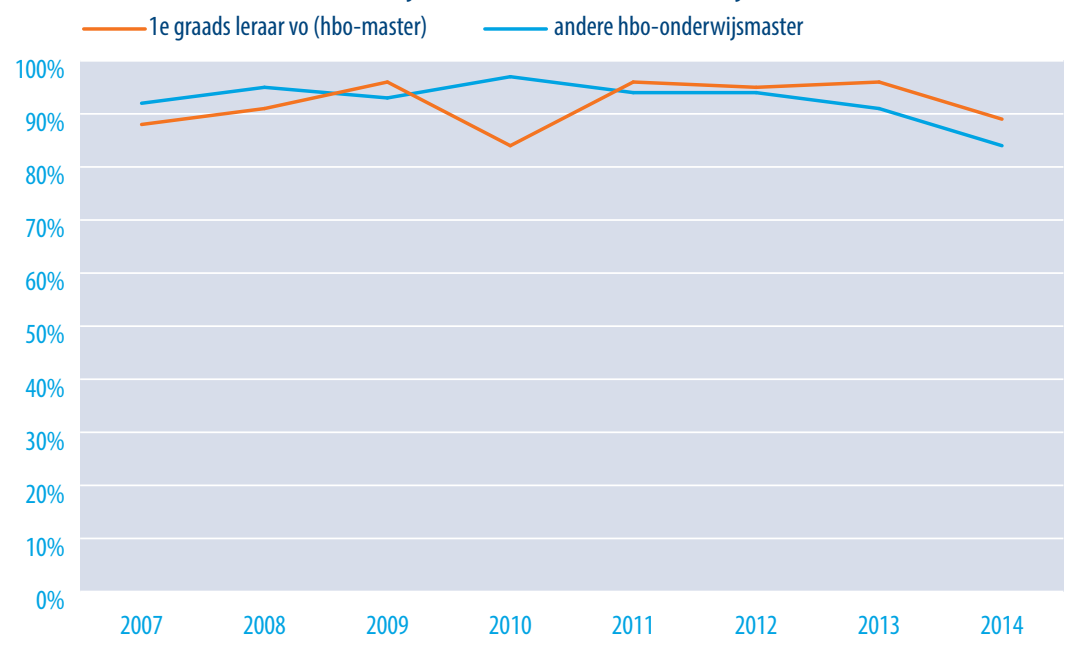

Bron: ROA, HBO-Monitor

\subsection{Lonen recent afgestudeerden}

\section{Hbo-bachelors}

Figuur 3.11 toont voor de periode (van afstudeerjaren) 1995-2014 de mediane bruto uurlonen $^{19}$ van recent afgestudeerden aan de lerarenopleidingen, afgezet tegen de mediane lonen van alle hbo'ers. De lonen zijn gecorrigeerd voor inflatie, waarbij afstudeerjaar 2014 als basisjaar is genomen. De figuur toont een opvallend beeld: waar afgestudeerde pabo'ers tussen 1996 en 2005 een hoger uurloon hadden dan het hbo-totaal, ligt hun uurloon na 2005 veelal beneden het hbo-totaal. Verder zien we dat het (inflatiegecorrigeerde) uurloon van pabo'ers vanaf 1998 vrijwel structureel dalende is. Dit in contrast met afgestudeerden aan de vo-lerarenopleidingen: onder deze groep is het mediane uurloon (fluctuaties daargelaten) sinds 1998 redelijk stabiel gebleven, waarbij het uurloon sinds 2001 structureel hoger ligt dan bij hbo-totaal.

Om voorgaande figuur meer in perspectief te plaatsen, toont Figuur 3.12 de bruto uurlonen in (jaarlijkse) verhoudingsgetallen voor lerarenopleidingen en twee opleidingsrichtingen ter referentie. Het verhoudingsgetal geeft aan hoe het gemiddelde uurloon voor de betreffende opleiding(srichting) zich verhoudt tot het gemiddelde uurloon van alle afgestudeerde (werkende) hbo'ers tezamen ${ }^{20}$. In de figuur zien we nog duidelijker dan in voorgaande figuur dat het uurloon van afgestudeerde pabo'ers van

19 Er is gekozen voor de mediaan, omdat deze minder gevoelig is voor hoge en lage 'uitschieters' dan het gemiddelde. Uit nadere analyse op de ontwikkeling in de gemiddelde lonen volgt overigens een ruwweg vergelijkbaar beeld.

20 Ter illustratie: bij een gemiddeld uurloon van $€ 11$,- voor opleiding $X$ in jaar $Y$ en een gemiddeld uurloon van $€ 10$,- in het totale hbo in jaar $Y$, betreft het verhoudingsgetal voor opleiding $X$ in jaar $Y: 1,1$. 
relatief hoog (verhoudingsgetal in afstudeerjaar 2004 boven 1,0) verschoven is naar laag (sinds afstudeerjaar 2009 structureel onder 1,0). De relatieve lonen (in termen van verhoudingsgetallen) voor afgestudeerden aan de vo-lerarenopleidingen zijn in de periode 1995-2014 juist bijna structureel toegenomen. Van gelijk aan het mediane hbouurloon in 1995 (verhoudingsgetal 1,0) tot fors boven het hbo-totaal in 2014: het verhoudingsgetal van 1,12 wijst op een 12 procent hoger loon voor vo-leraren opleidingen ten opzichte van hbo-totaal. Om de lonen van de afgestudeerden aan de lerarenopleidingen nog verder in perspectief te plaatsen, zijn tevens de verhoudingsgetallen voor de hbo-sectoren 'economie' en 'gedrag en maatschappij' weergegeven. Hieruit volgt dat afgestudeerde leraren (zowel po als vo) tot 2006 vrijwel structureel hogere uurlonen verdienden dan afgestudeerden uit de twee referentiesectoren. Vanaf 2006 is te zien dat de pabo'ers enigszins 'achterop' zijn geraakt ten opzichte van deze sectoren. Het mediane uurloon van afgestudeerden aan de vo-lerarenopleiding is juist al vele jaren achtereen fors hoger dan in de twee referentiesectoren.

FIGUUR 3.11 Mediaan bruto uurloon (incl. inflatiecorrectie) werkzame afgestudeerden hbo-lerarenopleidingen en hbo-totaal (voltijd, bachelor), anderhalf jaar na afstuderen, afstudeerjaren 19952014

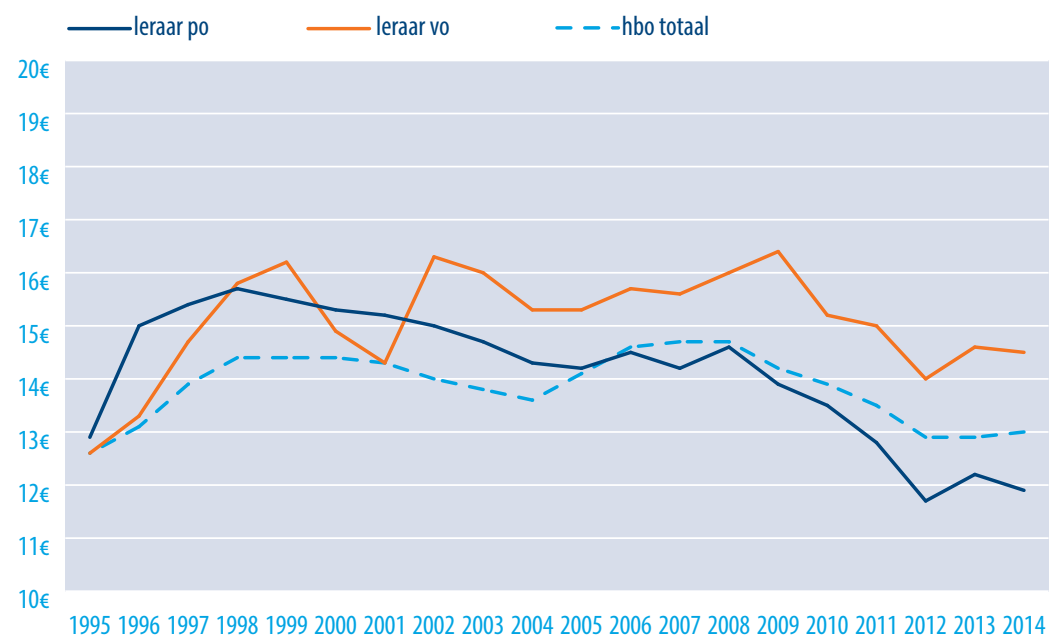

Bron: ROA, HBO-Monitor

Figuur 3.13 toont wederom de ontwikkeling in het mediaan bruto uurloon van afgestudeerden aan de lerarenopleiding, maar nu gespecificeerd voor afgestudeerde leraren die in het onderwijs terecht zijn gekomen versus leraren die in andere sectoren werkzaam zijn. We zien zowel voor afgestudeerde leraren aan de pabo, als aan de vo-lerarenopleidingen, dat zij in het onderwijs bijna structureel meer verdienen dan afgestudeerde leraren die in andere sectoren werken. 
FIGUUR 3.12 Mediaan bruto uurloon (incl. inflatiecorrectie) werkzame afgestudeerden hbo-lerarenopleidingen en twee referentiesectoren (voltijd, bachelor), anderhalf jaar na afstuderen, uitgedrukt als verhoudingsgetal t.o.v. mediaan uurloon hbo-totaal betreffende jaar, afstudeerjaren 1995-2014

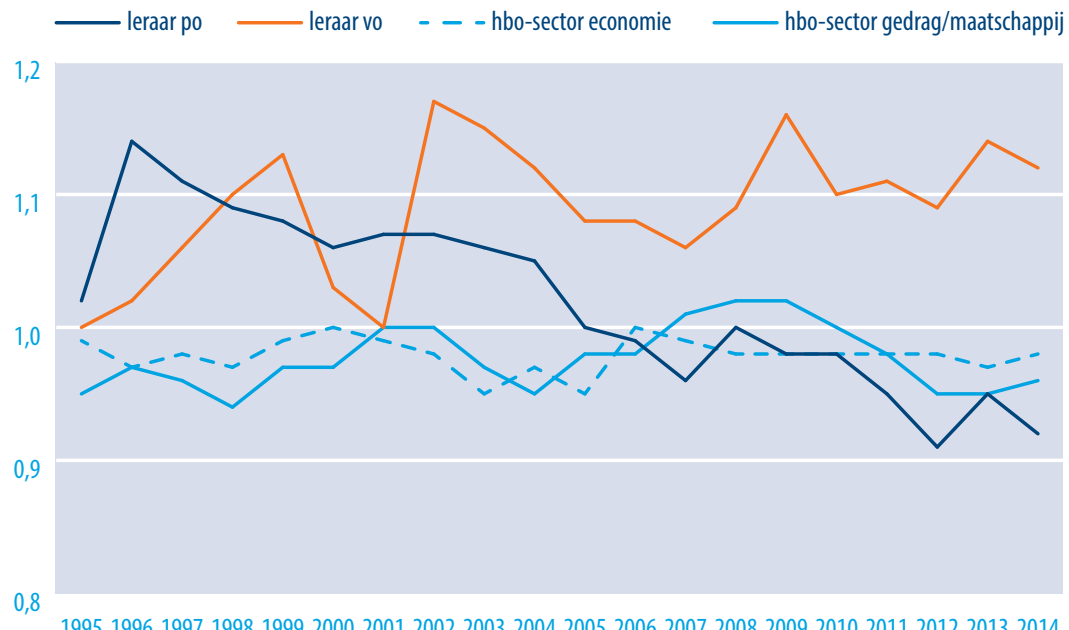

19951996199719981999200020012002200320042005200620072008200920102011201220132014

Bron: ROA, HBO-Monitor

FIGUUR 3.13 Mediaan bruto uurloon (incl. inflatiecorrectie) werkzame afgestudeerden hbo-lerarenopleidingen (voltijd, bachelor), anderhalf jaar na afstuderen, naar sector waar men werkzaam is, afstudeerjaren 1995-2014

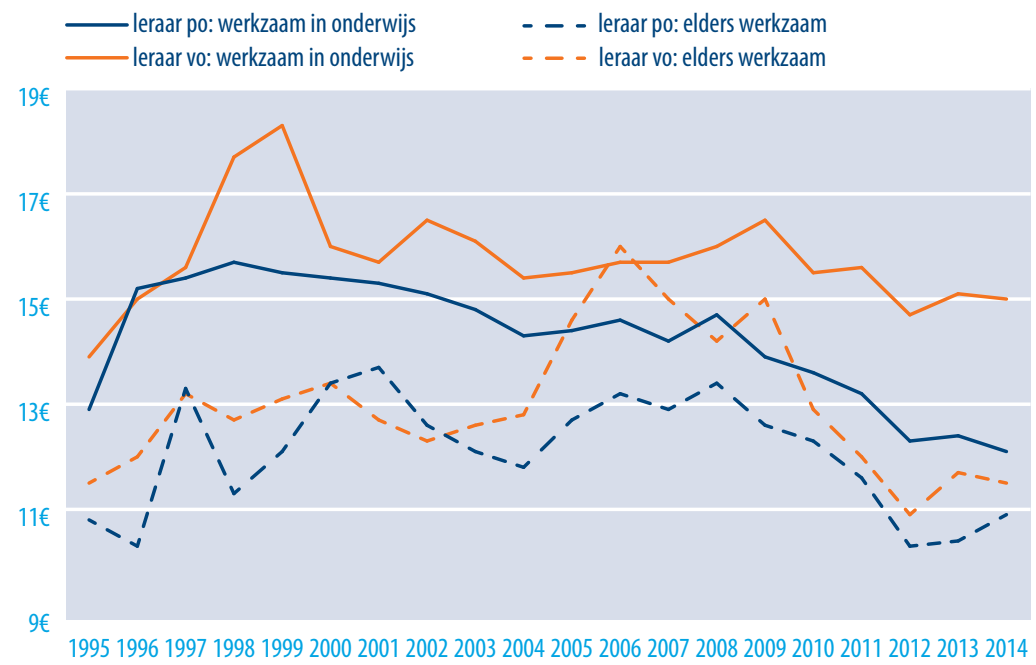

Bron: ROA, HBO-Monitor

De vorige figuur liet zien dat de lonen van afgestudeerden van lerarenopleidingen veelal hoger zijn als ze binnen in plaats van buiten het onderwijs werkzaam zijn. Het is echter 
goed denkbaar dat dit verklaard wordt doordat leraren die niet in het onderwijs werken noodgedwongen (tijdelijk) minder aantrekkelijke banen aannemen in hun zoektocht naar een onderwijsbaan. Om zoveel mogelijk te corrigeren voor dergelijke 'overbruggingsbanen', toont Figuur 3.14 alleen de lonen voor afgestudeerde leraren die een baan op hbo/wo-niveau hebben gevonden ${ }^{21}$. Voor afgestudeerden aan de pabo zien we dat de lonen in het onderwijs en in andere sectoren elkaar niet veel ontlopen. In sommige jaren verdienen de pabo'ers iets meer in het onderwijs, in andere jaren iets meer buiten het onderwijs. Voor afgestudeerden aan de vo-lerarenopleidingen zien we echter dat indien zij in het onderwijs werken, zij bijna structureel (fors) hogere lonen verdienen dan buiten het onderwijs.

FIGUUR 3.14 Mediaan bruto uurloon (incl. inflatiecorrectie) werkzame afgestudeerden hbo-lerarenopleidingen (voltijd, bachelor), anderhalf jaar na afstuderen, naar sector waar men werkzaam is, alleen indien men baan op hbo/wo-niveau heeft, afstudeerjaren 1995-2014

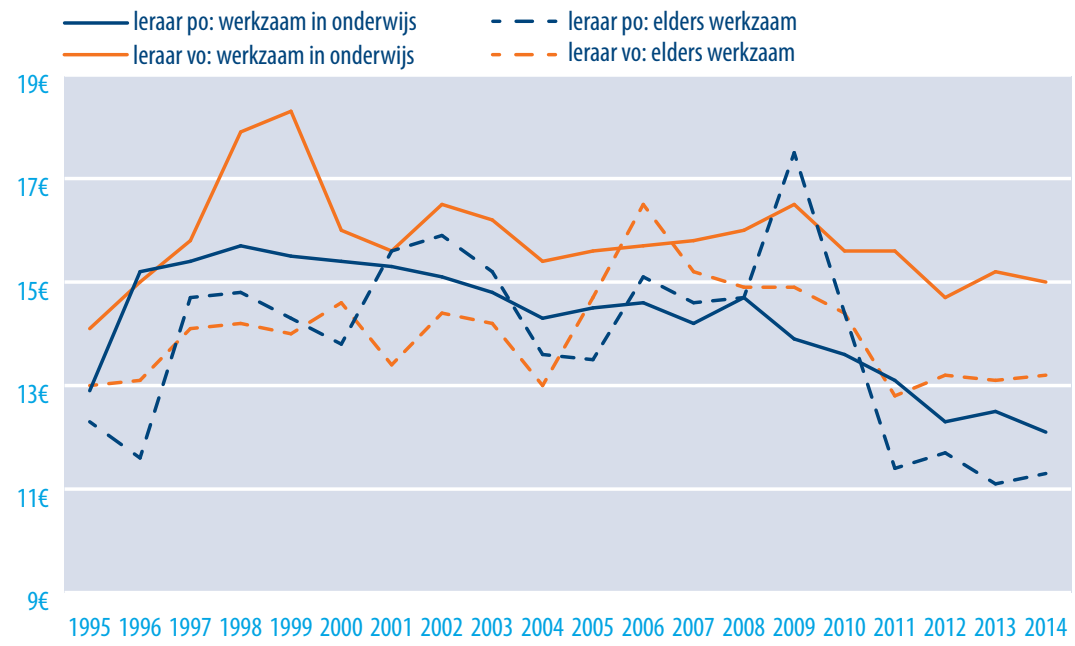

Bron: ROA, HBO-Monitor

\section{Hbo-masters}

De lonen van afgestudeerde hbo-onderwijsmasters liggen fors hoger dan bij afgestudeerden aan hbo-bachelor lerarenopleidingen. Het gaat hier dan ook vaak om leraren die werk met een opleiding combineren en derhalve meestal wat ouder zijn. In Figuur 3.15 is te zien dat de lonen van afgestudeerden aan de eerstegraads hbo-lerarenopleiding de afgelopen jaren zijn gestegen, van ongeveer 21 euro per uur in 2008 tot ruim 24 euro per uur in 2014. De lonen voor afgestudeerden aan de andere hbo-onderwijsmasters liggen lager en zijn de laatste jaren (2011-2014) tevens gedaald. De structureel hogere lonen voor afgestudeerden aan eerstegraads opleidingen hangt ermee samen

21 Natuurlijk betekent dit niet per se dat leraren die buiten het onderwijs op hbo/wo-niveau werken geen baan in het onderwijs ambiëren (net zo min als dat omgekeerd per se het geval is). Wel maakt het betere vergelijkingen tussen het onderwijs en andere sectoren mogelijk. 
dat deze leraren (veelal) in het eerstegraads domein van het vo les geven (in de bovenbouw), terwijl afgestudeerden van andere hbo-onderwijsmasters, met name de master 'educational needs', vaak voorbereiden op het speciaal onderwijs.

FIGUUR 3.15 Mediaan bruto uurloon (incl. inflatiecorrectie) werkzame afgestudeerden hbo-onderwijsmasters, anderhalf jaar na afstuderen, afstudeerjaren 2007-2014

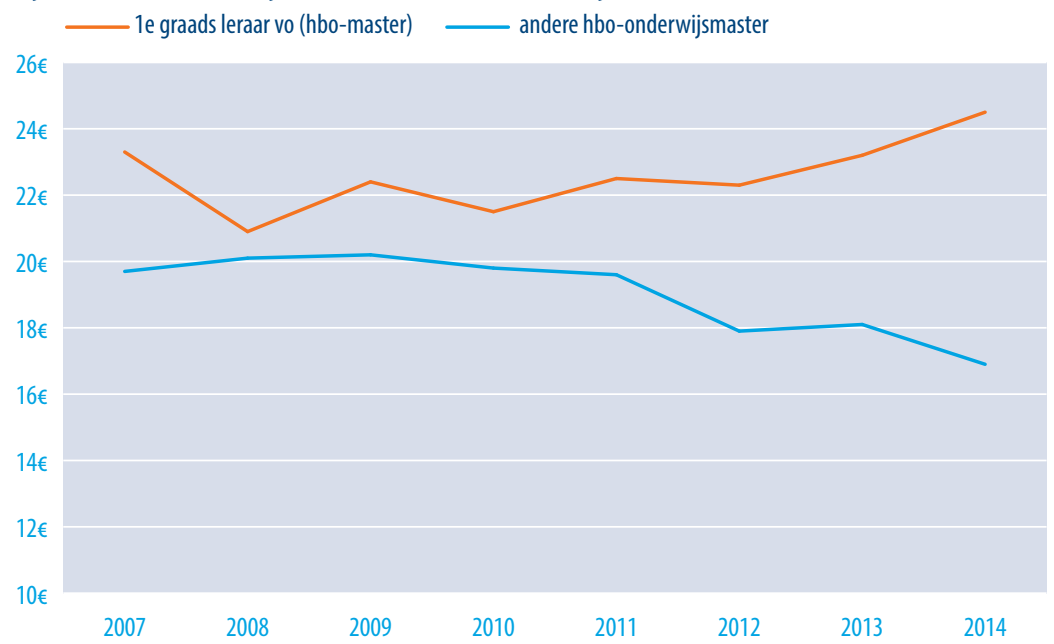

Bron: ROA, HBO-Monitor

\subsection{Functiemix}

In dit deel verschuiven we de aandacht van (recent) afgestudeerde leraren naar de arbeidsmarktpositie van de gehele lerarenformatie in Nederland. Eerst kijken we naar de ontwikkeling in de zogenaamde 'functiemix'. Dit is de verdeling van leraren over de verschillende salarisschalen. Figuur 3.16 toont deze functiemix voor het basisonderwijs. Hieruit volgt een duidelijke toename in het aandeel leraren in schaal LB. Waar in 2006 vrijwel alle leraren in aanvangsschaal LA zaten (99\%) en slechts 1 procent in schaal LB, zien we dat het aandeel LB'ers in 2015 is gegroeid tot ruim een kwart (26\%). Met name sinds 2009 groeide het aandeel LB'ers snel, vanaf dat jaar ontvangen scholen extra geld voor de versterking van de functiemix.

Ook in het speciaal onderwijs is er een trend naar meer leraren in hogere salarisschalen zichtbaar, zij het iets minder prominent dan in het basisonderwijs. In het speciaal onderwijs is schaal LB de gangbare aanvangsschaal. Waar in 2006 nog 2 procent van de so-leraren in LC was ingeschaald, betreft het in 201513 procent. De toename in het aandeel LC'ers heeft ook hier door de impuls in de financiële middelen van scholen vanaf 2009 plaatsgevonden. 


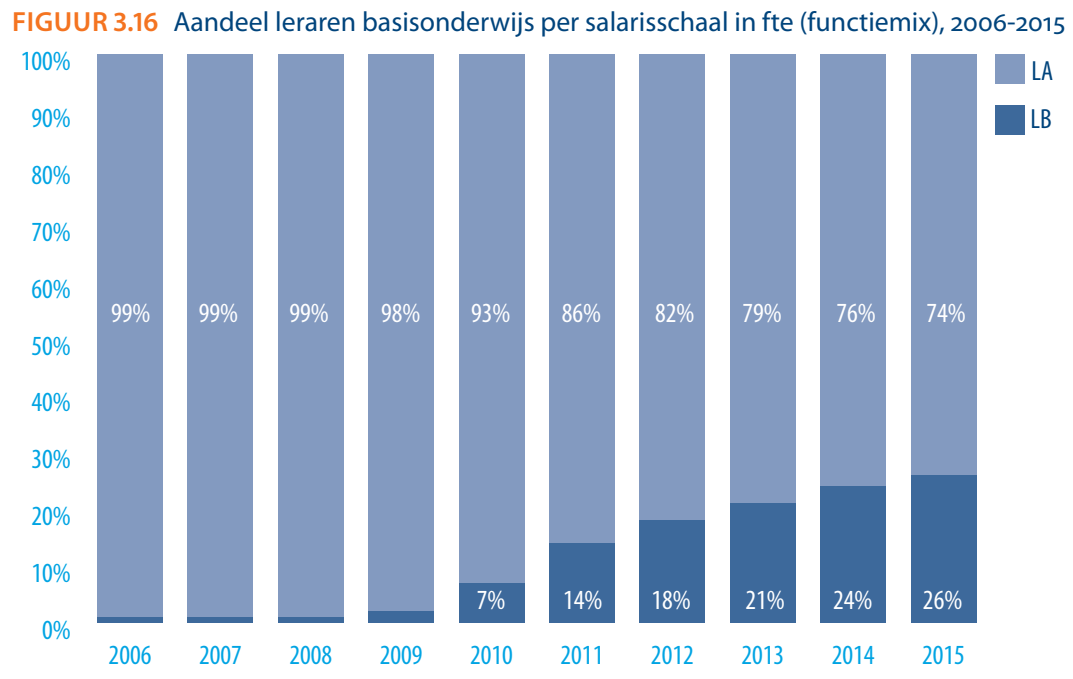

Bron: Functiemix.ocw.nl

FIGUUR 3.17 Aandeel leraren speciaal (basis)onderwijs per salarisschaal in fte (functiemix), 20062015

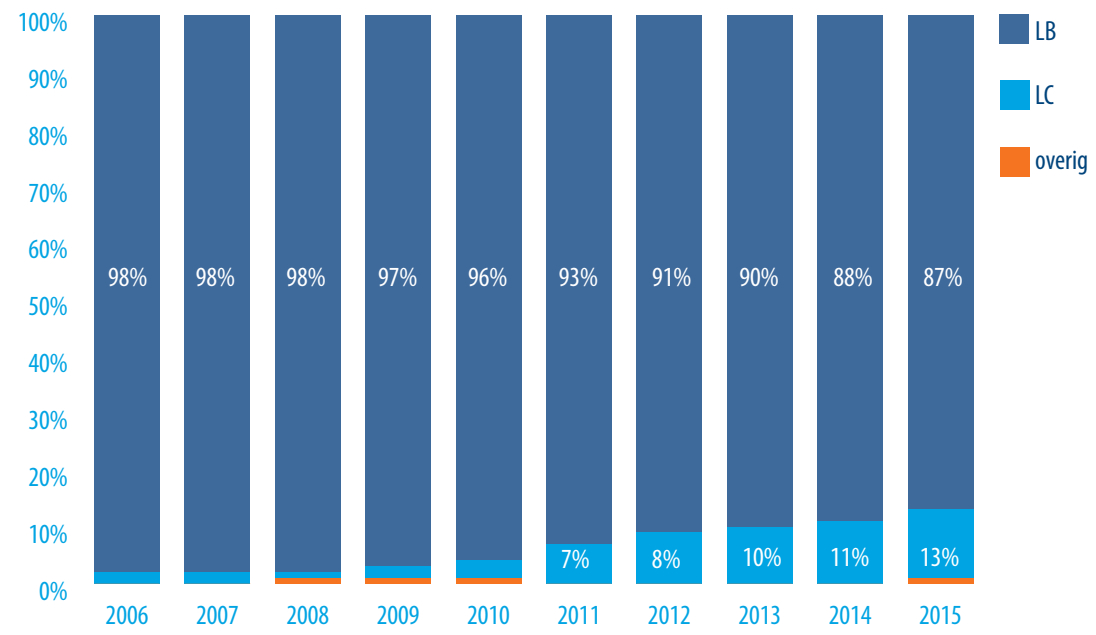

Bron: Functiemix.ocw.nl 
In het voortgezet onderwijs is er van oudsher al meer variatie in de salarisschalen dan in het primair onderwijs, ook vóór 2009 (het jaar waarin extra middelen beschikbaar werden gesteld). Zo is in Figuur 3.18 te zien dat in 2006 reeds 35 procent van de leraren hoger dan basisschaal LB waren ingeschaald (17\% in LC, 18\% in LD). In 2015 is inmiddels 58 procent van de leraren hoger dan LB ingeschaald, waarvan 31 procent in LC en 27 procent in LD.

FIGUUR 3.18 Aandeel leraren voortgezet onderwijs per salarisschaal in fte (functiemix), 2006-2015

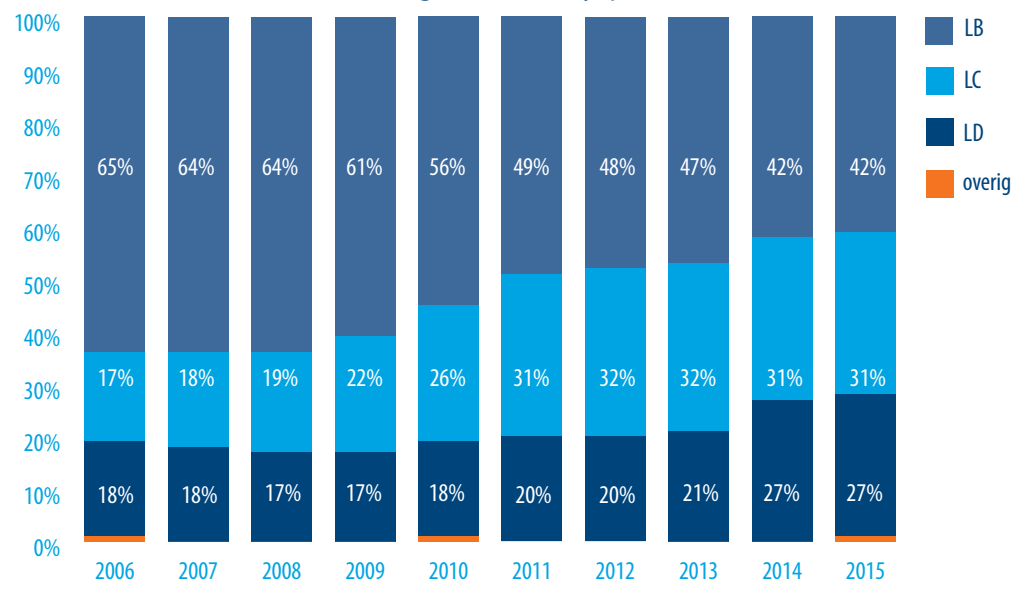

Bron: Functiemix.ocw.nl

\subsection{Relatieve lonen}

In Figuur 3.19 is de verandering van de gemiddelde beloning per gewerkt uur van werknemers in de onderwijssector ${ }^{22}$ afgezet tegen het totaal over alle sectoren. Het uurloon is in de jaren zeventig en tachtig in het onderwijs ten opzichte van het gemiddelde in alle sectoren sterk gedaald. Vermoedelijk spelen hier zowel de bezuinigingen op de lerarensalarissen als het toenemende opleidings- en functieniveau in andere sectoren een rol, waardoor de relatieve 'loonvoorsprong' in het onderwijs afnam (Cörvers, 2014). Vanaf eind jaren tachtig is het relatieve beloningsverschil voor werknemers in de onderwijssector ruwweg stabiel gebleven rond de $20 \%$. Sindsdien zijn de lonen in het onderwijs ongeveer vergelijkbaar met die in de sector 'openbaar bestuur'.

22 De gegevens laten niet toe dat er kan worden uitgesplitst naar bijvoorbeeld po en vo. Noch kan er worden gecorrigeerd voor de samenstelling van de werknemerspopulatie binnen het onderwijs 
FIGUUR 3.19 Relatieve beloningsverschil per gewerkt uur voor de onderwijssector en drie andere aan de overheid gerelateerde sectoren, ten opzichte van totaal van sectoren, 1969-2012

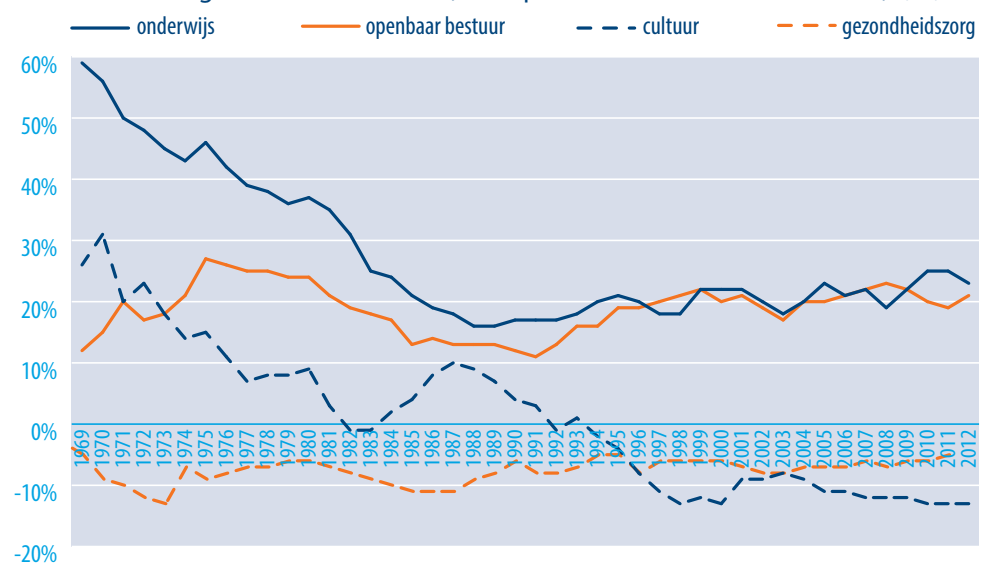

Bron: CBS (Arbeidsrekeningen)

\subsection{Reflectie}

De werkloosheid onder pas afgestudeerden van de bacheloropleidingen voor 'leraar vo' ligt al meer dan tien jaar fors onder het hbo-gemiddelde. De werkloosheidsontwikkeling onder pas afgestudeerde leraren van de pabo en de ulo is veel grilliger, soms onder en soms boven het hbo-gemiddelde. In de meting van 2015 (afgestudeerden uit 2014, ca. een jaar na afstuderen) ligt de werkloosheid onder afgestudeerden van zowel de pabo als de tweedegraads lerarenopleiding vo en de ulo relatief laag op ruim 4 procent, tegen een hbo-gemiddelde van 6 procent. Afgestudeerden van de pabo hebben vergeleken met andere hbo-afgestudeerden minder vaak een vast dienstverband. Afgestudeerden aan de opleiding 'leraar vo' hebben juist relatief vaak een vaste aanstelling. Voor de afgestudeerden van de hbo-masteropleidingen zijn de werkloosheidspercentages erg laag en is het aandeel met een vast dienstverband erg hoog, omdat het hier vaak studenten betreft die al als leraar werkzaam waren en die duaal of in deeltijd de lerarenopleiding hebben gevolgd.

Verreweg de meest afgestudeerden van de lerarenopleidingen komen in het onderwijs terecht. Afhankelijk van de databron en het type lerarenopleiding (pabo, eerste- of tweedegraad vo) is dat tussen 70 en 90 procent van de pas afgestudeerde leraren. Voor de hbo-onderwijsmasters is dat zelfs bijna 100 procent omdat zij vaak een baan in het onderwijs combineren met een masteropleiding. Hier blijkt een positieve selectie plaats te vinden: afgestudeerden aan hbo-lerarenopleidingen met een hoger gemiddeld afstudeercijfer hebben een grotere kans om in het onderwijs te werken. Ook hebben afgestudeerden van hbo-lerarenopleidingen een grotere kans om een baan te bemachtigen op (minimaal) hbo-niveau, vergeleken met afgestudeerden van andere richtingen. Als afgestudeerden van lerarenopleidingen echter buiten het onderwijs gaan werken, dan 
daalt de kans op een baan op niveau met de helft of meer. Over het algemeen is ook het loon lager als men buiten het onderwijs gaat werken.

Afgestudeerden aan de lerarenopleiding voor het vo verdienen relatief goed: het mediane uurloon van deze groep ligt al vele jaren ongeveer 10 procent hoger dan het gemiddelde onder afgestudeerden van het gehele hbo. Afgestudeerde pabo'ers verdienden tussen 1995 en 2005 meer dan andere hbo-afgestudeerden, maar na 2008 is hun mediane uurloon juist lager dan dat van andere hbo-afgestudeerden. Bovendien is de afstand tussen de lonen van de pabo'ers en de overige hbo'ers, en met name tussen pabo'ers en vo-leraren gedurende de laatste jaren steeds groter geworden. De lonen van de gehele beroepsgroep van leraren, dus niet alleen de recent afgestudeerden, blijken de afgelopen decennia verhoudingsgewijs lager te zijn geworden. Waar het onderwijs in de jaren zestig en zeventig, vergeleken met andere sectoren in het publieke domein, relatief hoge lonen kende, zijn de beloningsverschillen daarna steeds kleiner geworden. De 'exclusiviteit' van het onderwijs in termen van beloning is verkleind. Wel zijn in het kader van de functiemixmaatregel de laatste jaren veel meer leraren in hogere salarisschalen terechtgekomen. 


\section{IMAGO: HET BEROEP LERAAR}

\subsection{Inleiding}

In dit hoofdstuk gaan we in op het imago van het beroep van leraar. Naast status wordt ook het imago van de leraar in ons onderzoek beschouwd als factor die de aantrekkelijkheid van het leraarschap mede bepaalt. Bij imago staat de beeldvorming over de leraar centraal, inclusief het zelfbeeld. Omdat het imago (of maatschappelijk aanzien) van het beroep van leraar voor diverse groepen zal verschillen, kiezen we voor het presenteren van verschillende perspectieven. Met die verschillende perspectieven geven we invulling aan de vermoedelijke gelaagdheid waaruit het totale imago is opgebouwd. We onderscheiden het beroep vanuit de perspectieven van:

- de beroepsgroep zelf (leraren in po, vbo en mbo);

- de instroom in de beroepsgroep (studenten op de lerarenopleiding) ${ }^{23}$;

- de leerlingen (beperkt tot het voortgezet onderwijs en mbo);

- de ouders van leerlingen (po, vo, mbo);

- de Nederlandse bevolking.

Eén en ander is weergegeven in Figuur 4.1.

FIGUUR 4.1 Imago van de leraar vanuit verschillende invalshoeken bekeken

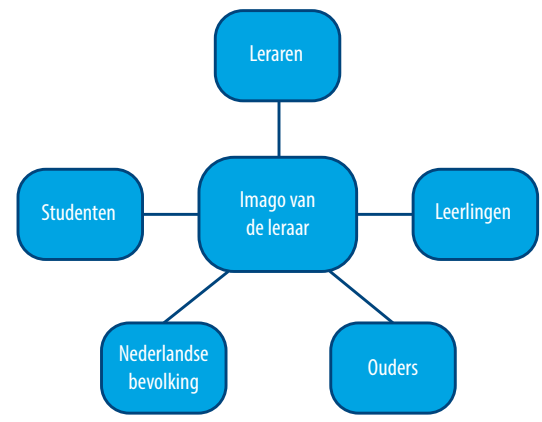

23 Studenten aan de lerarenopleiding beslaan twee respondentgroepen: studenten aan de pabo die hun mening geven over het primair onderwijs en studenten aan de lerarenopleidingen voor 1e en ze graads leraar, die hun mening geven over het vo en/of mbo. De laatste groep is samengenomen en wordt derhalve zowel bij vo en mbo weergegeven. We kunnen bij deze groep dus niet testen op verschillen in meningen over vo en mbo. 
Deze respondentgroepen hebben (deels) dezelfde vragen voorgelegd gekregen over waardering voor het beroep van leraar en de mate waarin leraren goed zijn in de uitoefening van hun beroep. In Bijlage IV zijn de vragenlijsten opgenomen.

\subsection{Waardering voor het beroep van leraar}

We hebben respondenten gevraagd wat ze denken over de waardering van de Nederlandse bevolking voor leraren en of die waardering in de afgelopen twintig jaar veranderd is. Ook hebben we onder andere aan ouders gevraagd of ze veel of weinig waardering hebben voor leraren, en aan leraren naar de mate waarin ze verwachten dat hun leerlingen en/of studenten waardering voor hen hebben. We bespreken hieronder alleen de significante verschillen.

Onder de figuren met alle respondentgroepen, bespreken we per respondentgroep de waardering voor het vak van leraar (perspectief van...), eventueel vanuit de mening van een andere respondentgroep. Zo vroegen we leraren over de waardering die leerlingen voor hen hebben op een schaal van 1 (heel weinig waardering) tot 5 (heel veel waardering).

We starten met de vraag naar de inschatting van respondenten in hoeverre de Nederlandse bevolking veel of weinig waardering heeft voor leraren (Figuur 4.2). De schaal loopt van heel weinig waardering (1) tot heel veel waardering (5). De waardering loopt uiteen van 2,5 tot 3,2. We hebben respondentgroepen vervolgens gevraagd in welke mate ze denken dat de waardering van de Nederlandse bevolking voor leraren gedurende de laatste 20 jaar meer of minder is geworden (Figuur 4.3). Op een schaal van 1 tot 5 (veel minder waardering tot veel meer waardering) zien we dat alle respondenten gemiddeld onder de 3 (noch meer, noch minder waardering) scoren; geen van de respondentgroepen verwacht gemiddeld dat de waardering voor leraren over de afgelopen 20 jaar is toegenomen. De verwachting is eerder dat deze is afgenomen. 
FIGUUR 4.2 Inschatting van waardering van Nederlandse bevolking voor leraren naar respondent-

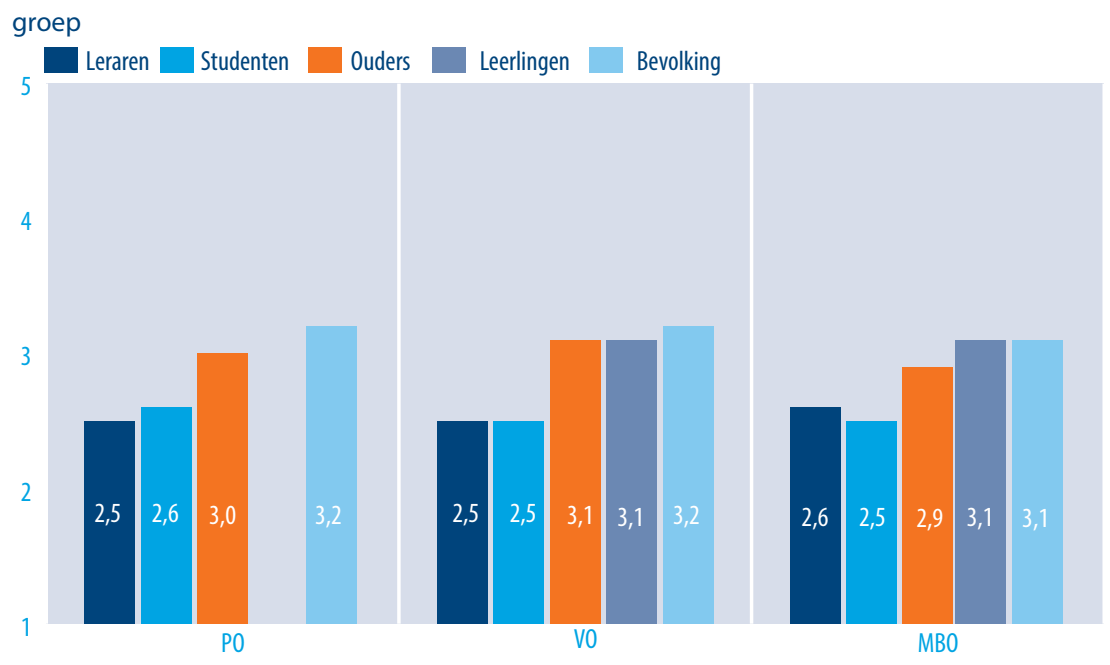

Leraren hebben geen hoge verwachtingen van de waardering van de Nederlandse bevolking voor hun vak. Ze waarderen dit gemiddeld tussen de 2,5 en 2,7 op een schaal van 1 tot 5 . Jongere leraren denken significant vaker dat de Nederlandse bevolking minder waardering heeft voor leraren dan oude leraren. Leraren scoren significant lager dan de Nederlandse bevolking zelf.

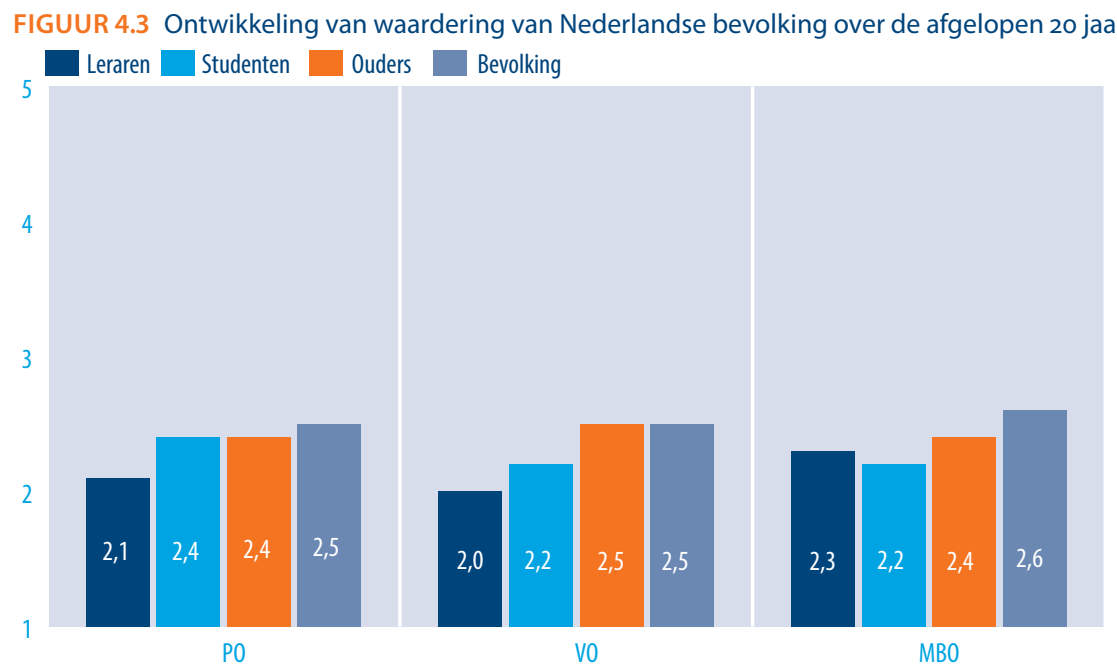

Leraren verwachten dat de Nederlandse bevolking minder waardering voor hen heeft gekregen over de afgelopen 20 jaar (2 tot 2,5). Ze scoren hier significant lager op dan de andere respondentgroepen: die vinden gemiddeld wel dat de waardering voor leraren afneemt, maar niet in de mate waarin leraren dat zelf ervaren (of inschatten). Leraren in 
het vo zijn verder significant negatiever over de ontwikkeling in waardering dan leraren in het mbo.

Net als leraren, hebben studenten van de lerarenopleiding geen hoge verwachting van hoe de Nederlandse bevolking het vak van leraar waardeert (Figuur 4.2: 2,5 tot 2,6 op een schaal van 1 tot 5). Studenten zijn negatiever dan de Nederlandse bevolking en positiever dan leraren over de ontwikkeling van de waardering van leraren in de afgelopen 20 jaar (significant; Figuur 4.3: 2,2 tot 2,4 op een schaal van 1 tot 5).

Ouders verwachten dat de Nederlandse bevolking (dus niet alleen ouders) het vak van leraar waardeert met een 3 tot 3,1 op een schaal van 1 tot 5 (Figuur 4.2). Ze zijn hiermee positiever dan leraren en studenten aan de lerarenopleiding, maar negatiever dan de Nederlandse bevolking zelf. Ouders die zelf leraar zijn (geweest), schatten de waardering voor het vak van leraar lager in dan ouders die geen leraar zijn (geweest). Verder verwachten ouders dat de waardering van de Nederlandse bevolking over de tijd niet méér is geworden (2,4 tot 2,5 op een schaal van 1 (veel minder) tot 5 (veel meer)) over de afgelopen 20 jaar (Figuur 4.3). Ondanks dat ouders vinden dat de waardering voor leraren niet méér is geworden, zijn ze - net als de respondenten uit de Nederlandse bevolking - wel het meest positief in vergelijking met de andere respondenten. De genoemde verschillen zijn significant.

FIGUUR 4.4 Inschatting van de waardering van ouders voor het beroep van leraar naar respondentgroep

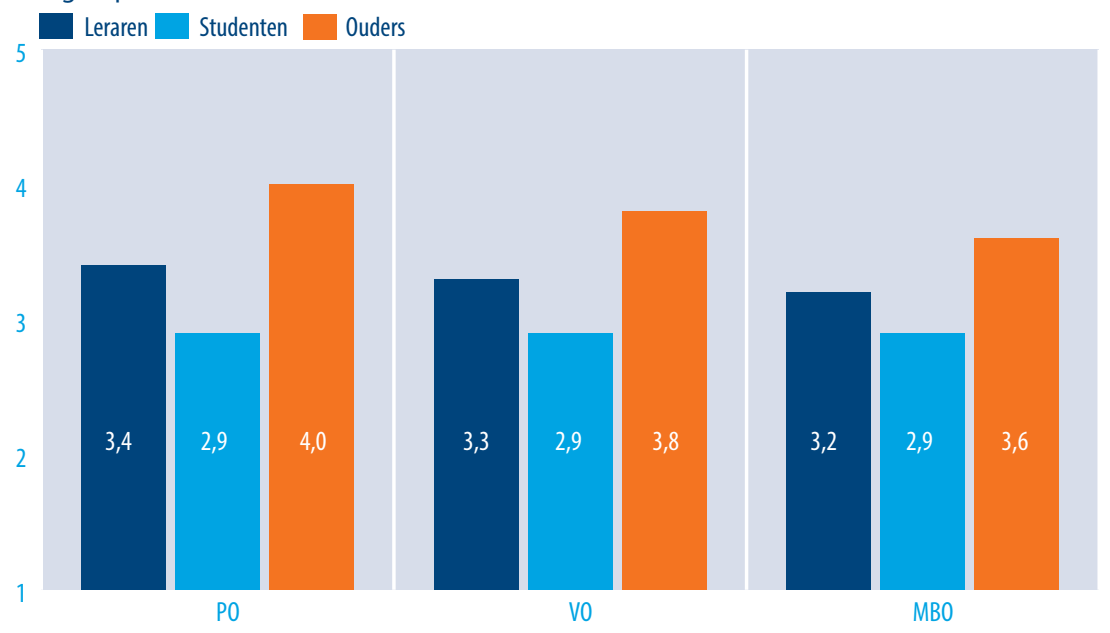

Leraren verwachten dat ouders van hun leerlingen hen waarderen met een 3,2 tot 3,4 op een schaal van 1 tot 5 (Figuur 4.4). Deze inschatting is significant lager dan de waardering die ouders zelf aangeven te hebben en significant hoger dan de inschatting van studenten aan de lerarenopleiding. Studenten aan de lerarenopleiding verwachten dat 
ouders leraren met een 2,9 waarderen op een schaal van 1 tot 5 . Dit is vergeleken met leraren en ouders de laagste waardering.

Ouders geven significant hogere scores dan de andere respondentgroepen als het gaat om de waardering die zij hebben voor leraren (gemiddeld 3,6 tot 4 op een schaal van 1 tot 5). Een verklaring hiervoor zou kunnen zijn dat de vraag aan ouders expliciet gaat over de leraren van hun kinderen, terwijl de overige respondentgroepen is gevraagd over hun inschatting van de waardering van ouders. Er zijn slechts geringe verschillen in de door leraren en studenten in opleiding verwachte waardering van ouders over de verschillende onderwijsvormen (po, vo, mbo). Wel lijken ouders de meeste waardering te hebben voor leraren van po en de minste voor mbo-leraren ten opzichte van vo-leraren (significant). Dat sluit ook aan bij de verwachtingen die leraren hebben, hoewel de verschillen tussen de onderwijsvormen kleiner zijn dan bij de ouders.

We hebben leraren gevraagd of ze denken dat hun leerlingen of studenten veel of weinig waardering voor hen als leraar hebben. Leraren zijn hier best positief over (met een score van 3,4 tot 3,8 op een schaal van 1 tot 5; Figuur 4.5). Leraren in het po zijn significant positiever over de waardering van hun leerlingen dan leraren in het mbo en vo. Tussen de laatste twee groepen zijn geen significante verschillen waar te nemen.

FIGUUR 4.5 Inschatting van waardering van leerlingen / studenten voor hun leraren door leraren

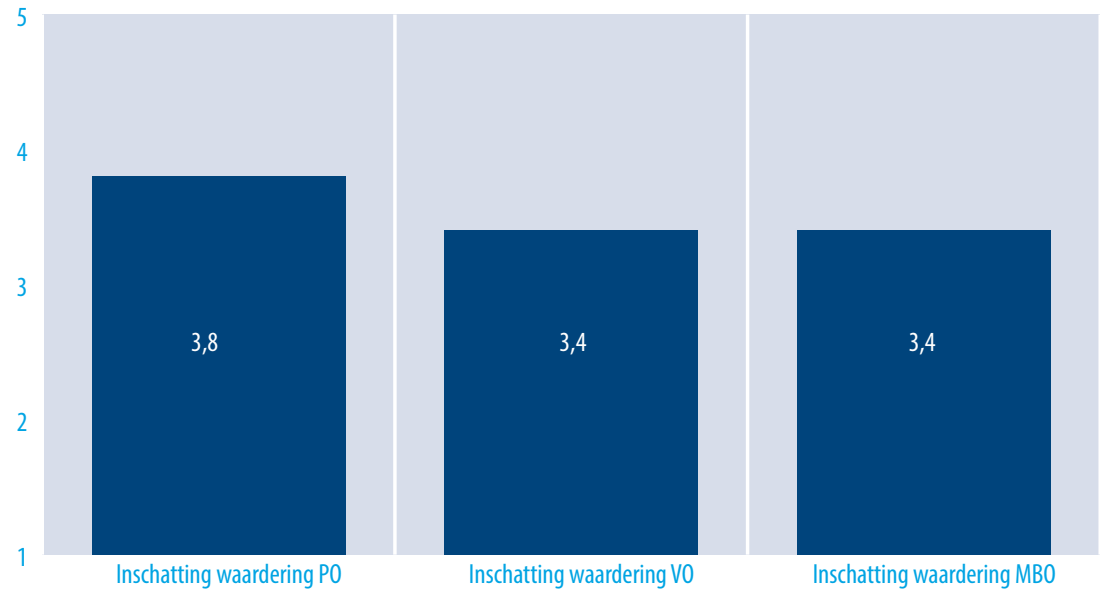

Respondenten uit de groep "Nederlandse bevolking" geven aan dat ze inschatten dat de Nederlandse bevolking leraren waardeert met een 3,1 tot 3,2 op een schaal van 1 tot 5 (Figuur 4.2). Zij zijn daarmee het meest positief over het oordeel van de Nederlandse bevolking. Dit geldt ook voor de ontwikkeling in waardering: de Nederlandse bevolking is - net als ouders - het minst negatief over de ontwikkeling in de waardering van leraren (2,5 tot 2,6 op een schaal van 1 tot 5 volgens Figuur 4.3). Respondenten uit de Nederlandse bevolking die zelf leraar zijn geweest schatten vaker in dat de waardering 
over de afgelopen 20 jaar minder is geworden dan respondenten die zelf geen leraar zijn geweest (significant).

De redenen die genoemd worden door de verschillende respondenten om de mate van waardering door de Nederlandse bevolking (dat wil zeggen wat respondenten denken dat men vindt of dat anderen vinden) toe te lichten, hebben (globaal) te maken met de volgende thema's:

- Respect: men vindt dat er tegenwoordig weinig respect is voor leraren. De leerlingen van tegenwoordig zijn veranderd;

- Uitdaging: men vindt dat het een uitdaging is om met leerlingen, en vooral met pubers, te werken;

- Kennis van zaken: leraren geven aan dat ouders steeds meer denken dat ze "maar wat doen" en dat veel van de lesstof ook via bijvoorbeeld het internet wel vergaard kan worden;

- Kennisoverdracht: men vindt dat leraren kennis overbrengen en kinderen klaarstomen voor de maatschappij;

- Rol van de media: men vindt dat leraren vaak negatief in beeld zijn;

- Omgang met ouders: leraren vinden dat de waardering voor leraren sterk afhankelijk is van de resultaten die het kind op school behaalt;

- Opvoedrol: men verwacht van leraren steeds meer (ook) een opvoedkundige rol verwacht;

- Werkdruk: men vindt dat de werkdruk hoog is en dat dat vaak niet wordt gezien, men denkt dat leraren alleen maar vakantie hebben.

\section{Verschillen naar leeftijd, dienstjaren en geslacht}

We hebben voor leraren en de Nederlandse bevolking verschillen in waardering voor verschillende leeftijden in kaart gebracht ${ }^{24}$. Voor de waardering van het beroep van leraar zien we voor zowel leraren als de Nederlandse bevolking dat hoe ouder de respondent is, hoe meer waardering hij of zij uitdrukt voor het beroep van leraar. Met het oplopen van het aantal dienstjaren worden leraren in het po en vo significant positiever over de waardering voor het lerarenberoep. Leraren met meer dienstjaren in het po vinden daarbij ook dat de waardering voor leraren over de afgelopen 20 jaar gestegen is, vergeleken met leraren met minder dienstjaren in het po. Leraren met meer dienstjaren in het mbo vinden juist dat de waardering voor leraren over de afgelopen 20 jaar gedaald is ten opzichte van hun collega's met minder dienstjaren. Er zijn geen significante verschillen tussen mannen en vrouwen als het gaat over waardering van het lerarenberoep op dit moment en de ontwikkeling daarin over de afgelopen 20 jaar.

24 We hebben er voor gekozen dit niet voor leerlingen en studenten in kaart te brengen, omdat deze in leeftijd niet genoeg uiteenlopen. Daarnaast geven we dit niet weer voor ouders, omdat de leeftijd van ouders verschilt met de leeftijd van hun schoolgaande kinderen. We zouden daarmee een sectorverschil naar boven halen (verschil tussen po, vo, mbo). 


\section{Verschillen naar school- en leraarkenmerken}

We hebben de antwoorden van leraren uitgesplitst naar de kenmerken van de scholen waarop zij lesgeven. Voor schoolgrootte zien we geen verschillen in waardering tussen de verschillende categorieën. We zien ook geen verschillen in type school voor het mbo (roc, aoc, vakschool of anders). Leraren op vo-scholen in een dorp of kleine stad vinden vaker dan leraren op vo-scholen in grote steden dat de waardering voor leraren over de afgelopen 20 jaar veranderd is (significant). Verder vinden we geen verschillen tussen kleine, middelgrote en grote steden voor de verschillende schooltypen als het gaat om waardering en de ontwikkeling daarvan.

Er zijn bijna geen verschillen in de opvattingen van leraren tussen verschillende salarisschalen in de verschillende schooltypen. We zien alleen in het mbo dat leraren in schaal LC significant positiever zijn over de algehele waardering voor het vak van leraar dan leraren in schaal LB. Er treden geen verschillen op tussen leraren die algemeen vormende vakken, beroepsgerichte of een combinatie van beide typen vakken geven in hun mening over de waardering van het lerarenberoep. Leraren in het vo die een eerstegraads lerarenopleiding hebben gevolgd aan de universiteit zijn significant positiever over de ontwikkeling van de waardering van het lerarenberoep over de tijd dan leraren met een tweedegraads opleiding. Het aandeel achterstandsleerlingen op scholen hangt niet samen met verschillen tussen scholen betreffende de mening over hoe het lerarenberoep in de maatschappij wordt gewaardeerd.

\section{Samenvattend}

De Nederlandse bevolking zelf schat de waardering voor het vak van leraar door de maatschappij (i.e. door de Nederlandse bevolking) het hoogste in, terwijl studenten aan de lerarenopleiding en leraren de waardering door de Nederlandse bevolking het laagst inschatten. Ouders en leerlingen zitten er tussenin wat betreft hun inschatting van de Nederlandse bevolking voor het leraarschap. Geen van de respondentgroepen geeft aan dat de waardering van leraren over de afgelopen 20 jaar is gestegen. Het minst negatief over de ontwikkeling in waardering zijn de ouders van leerlingen en de Nederlandse bevolking. Met name studenten aan de lerarenopleiding en leraren zelf zijn negatief over de ontwikkeling van de waardering.

In het po is de waardering van ouders voor leraren het hoogst, in het mbo het laagst ten opzichte van vo. Studenten op de lerarenopleiding schatten de waardering van ouders voor leraren het laagst in. Ouders hebben de meeste waardering voor leraren van hun kinderen, waarbij hier expliciet is gevraagd naar de waardering voor de leraren van hun kinderen (en dus niet volgens de projectieve vraagstelling naar de waardering van ouders in het algemeen over leraren in het algemeen). Dit kan dus eventueel verklaren dat zij bij deze vraag hoger scoren dan de andere respondentgroepen. 


\subsection{Waardering in de loop van de tijd}

Door in de vraagstelling aan te sluiten bij eerdere onderzoeken over ontwikkelingen in het onderwijs, zoals de Onderwijsmeter en TALIS, kunnen we de waardering van leraren over de tijd vergelijken.

\section{TALIS 2013}

In het TALIS onderzoek (Van der Boom en Stuivenberg, 2013) wordt gevraagd naar de mate waarin leraren in de onderbouw van het vo vinden dat het vak van docent wordt gewaardeerd door de maatschappij. In 2013 was 40 procent van de Nederlandse leraren van mening dat het vak van docent gewaardeerd wordt door de maatschappij.

Wij hebben leraren in 2016 gevraagd naar de mate waarin ze verwachten dat de Nederlandse bevolking veel waardering heeft voor het vak van leraar. We vergelijken met de meningen van leraren in het vo. In ons onderzoek geeft slechts 10 procent van de leraren vo aan dat ze verwachten dat de Nederlandse bevolking veel waardering heeft voor het vak van leraar. Geen van de respondenten uit de groep leraren geeft aan dat de Nederlandse bevolking heel veel waardering voor leraren heeft.

Deze resultaten schetsen dus een negatieve ontwikkeling van de waardering voor het vak van de vo-leraar in de maatschappij tussen 2013 en 2016, gezien vanuit het perspectief van de leraar. De kanttekening die hierbij geplaatst moet worden is dat het meten van het concept waardering verschilt in beide onderzoeken:

1. In TALIS 2013 wordt gevraagd in hoeverre men het eens is met de uitspraak "Ik denk dat het vak van docent wordt gewaardeerd door de maatschappij". De antwoordopties lopen uiteen van "zeer mee oneens" tot "zeer mee eens", zonder neutrale optie;

2. In ons onderzoek wordt gevraagd "Denkt u dat de Nederlandse bevolking in het algemeen (dus niet alleen ouders zoals de respondent in het TALIS onderzoek "de maatschappij" zou kunnen interpreteren) veel of weinig waardering heeft voor leraren in [type onderwijs]?" De antwoordopties lopen uiteen van "Heel weinig waardering" tot "Heel veel waardering", met een neutrale optie ("Noch veel, noch weinig waardering").

Het feit dat er in het TALIS onderzoek geen neutrale optie aangeboden wordt, zou ertoe kunnen leiden dat respondenten die geen sterke mening hebben, toch voor een positief antwoord kiezen. Het beeld kan daardoor iets positiever zijn dan het beeld dat uit ons onderzoek naar voren komt. Dit vermoeden wordt gesterkt doordat 40 procent van de ondervraagde leraren in het vo inderdaad heeft gekozen voor de neutrale optie (noch veel waardering, noch weinig waardering). 


\section{Onderwijsmeter 2007 en 2008}

In de Onderwijsmeter van 2007 (Gemmeke et al., 2007) en 2008 (Plantinga et al., 2008) wordt de vraag gesteld hoeveel waardering de Nederlandse bevolking heeft voor het vak van leraar. De respondentgroep is de Nederlandse bevolking. Wij vergelijken deze metingen met de vraag die wij hebben gesteld, voor de respondentgroep van de Nederlandse bevolking.

Tussen 2007 en 2008 zien we dat er een daling is opgetreden in het aandeel respondenten dat aangeeft veel waardering te hebben voor leraren (Figuur 4.6). De veronderstelde waardering in 2008 ligt ook lager dan de jaren voor 2007. Wel geeft TNS Nipo aan dat de cijfers over de jaren sterk fluctueren. In 2016 zien we weer een stijging in de waardering van leraren door de Nederlandse bevolking.

Deze stijging kan deels worden toegeschreven aan externe factoren, zoals de mate waarin leraren op een bepaald moment - al dan niet positief - in het nieuws komen. Daarnaast kan de manier van bevragen (respondenten hebben anno 2016 meerdere digitale tools om de vragenlijst op in te vullen, zoals smartphone en tablet). Echter, de toename is van een dusdanige aard dat we, met bovenstaande kanttekeningen, van een forse toename kunnen spreken.

FIGUUR 4.6 Hoeveel waardering heeft de Nederlandse bevolking voor het vak van leraar, volgens jou?

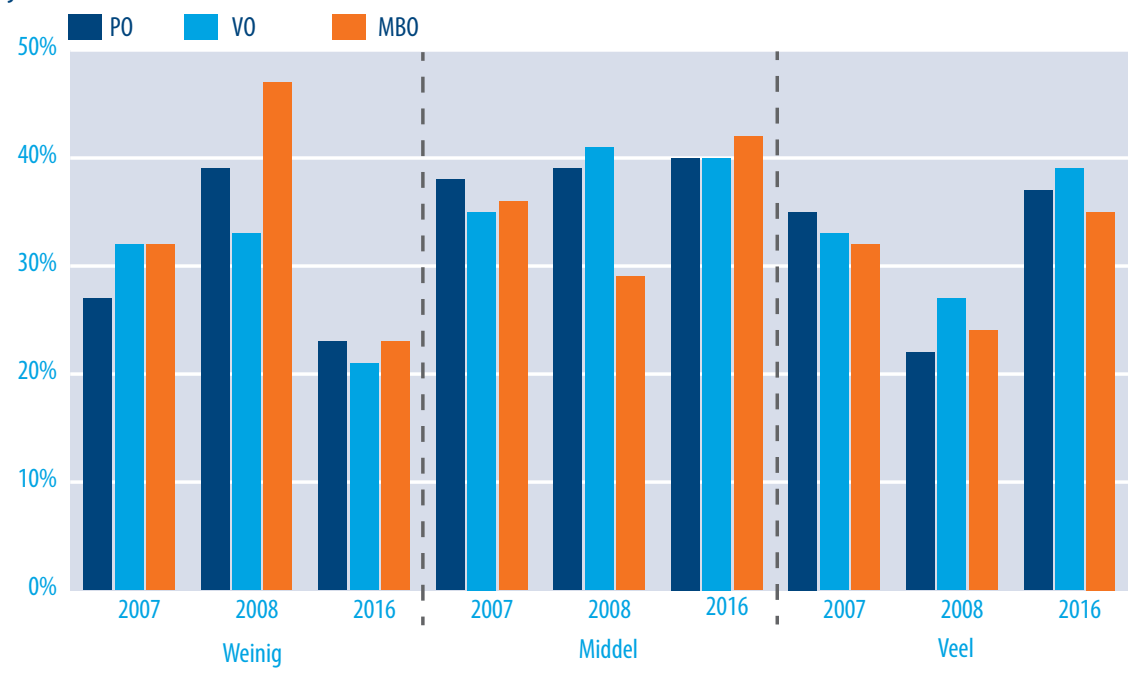

\subsection{Mening over beroepsuitoefening}

Hieronder geven we de resultaten weer van de mate waarin respondenten het eens zijn met een aantal uitspraken over leraren en hoe zij hun beroep uitoefenen. 
Op een schaal van 1 (helemaal mee oneens) tot 5 (helemaal mee eens) zijn respondenten neutraal tot het eens met de uitspraak dat leraren over het algemeen goed weten hoe ze kennis en vaardigheden aan leerlingen kunnen overdragen (Figuur 4.7). Leraren zijn hier het meest positief over, gevolgd door studenten van de lerarenopleiding. Leerlingen beoordelen leraren het laagst op het overbrengen van kennis en vaardigheden. In het po is men significant positiever dan in het vo en in het vo is men significant positiever dan in het mbo.

FIGUUR 4.7 Leraren in het [type onderwijs] weten over het algemeen goed hoe ze kennis en vaardigheden aan leerlingen kunnen overdragen

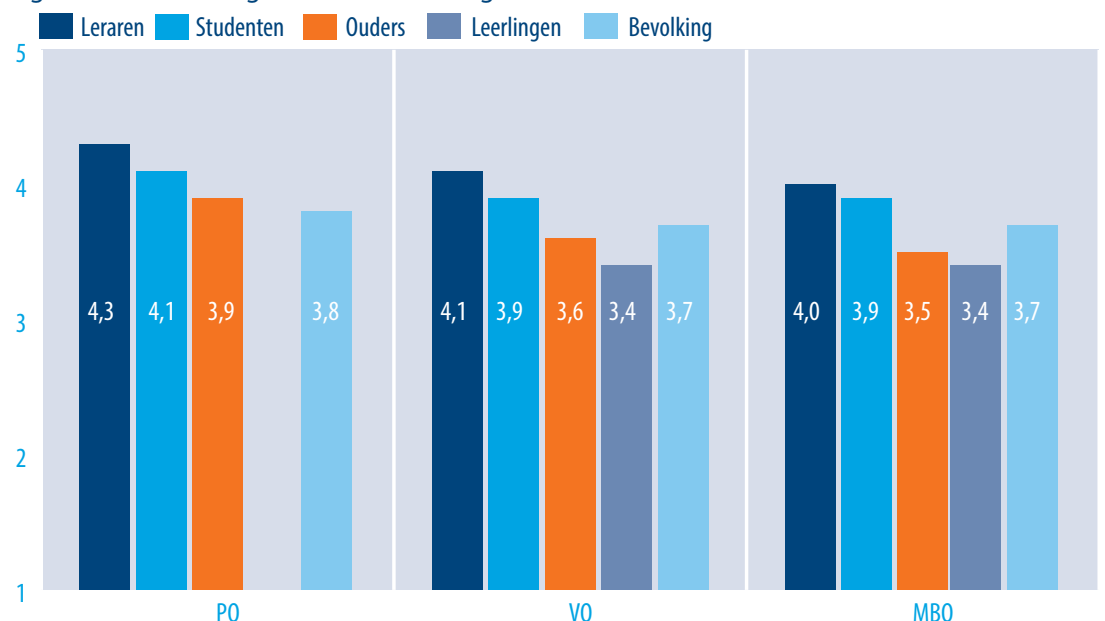

Respondenten waarderen de uitspraak dat leraren leerlingen goed kunnen motiveren tussen de 3,1 en 4,2 (Figuur 4.8). De verschillen treden zowel op tussen respondentgroepen als tussen onderwijstypen. Leraren zijn het meest positief over deze uitspraak, leerlingen het minst positief. De respondenten die leraren in het po waarderen, zijn het meer eens met deze uitspraak dan respondenten uit het vo en mbo.

Respondenten zijn redelijk positief over de vakkennis die leraren hebben (score van 3,6 tot 4,4 op een schaal van 1 tot 5; Figuur 4.9). Leraren en studenten op de lerarenopleiding zijn het meest positief, gevolgd door leerlingen, ouders en de Nederlandse bevolking, die op hetzelfde niveau zitten qua waardering van deze uitspraak. Er zijn geen eenduidige verschillen tussen po, vo en mbo. 
FIGUUR 4.8 Leraren in het [type onderwijs] kunnen leerlingen over het algemeen goed motiveren

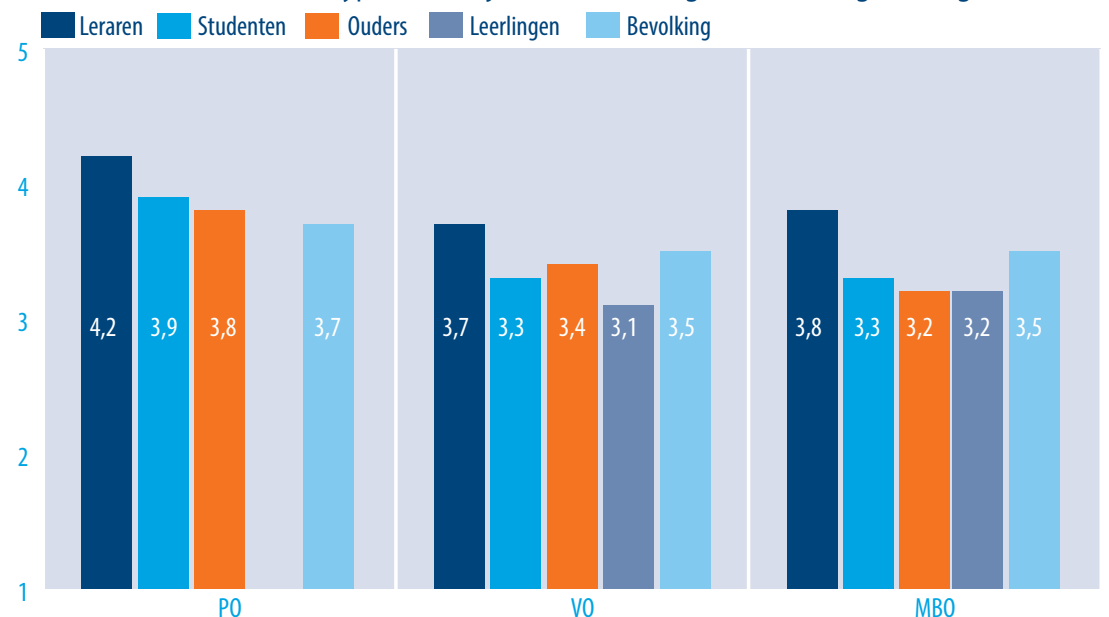

FIGUUR 4.9 Leraren in het [type onderwijs] hebben over het algemeen voldoende vakkennis (kennis van de vakken waarin ze lesgeven)

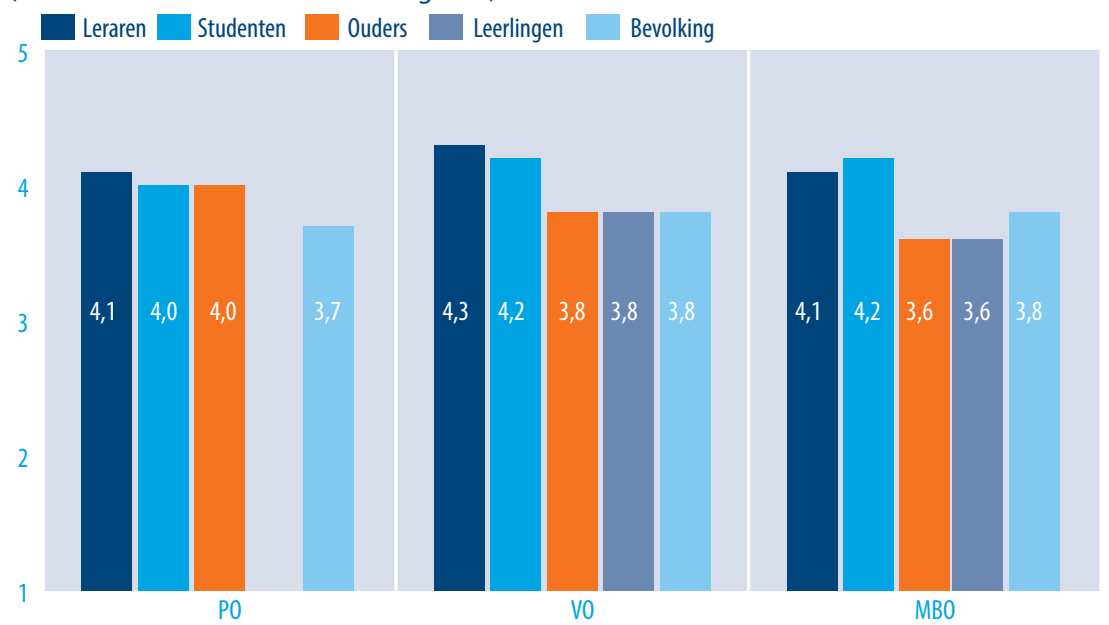

Respondenten zijn redelijk positief over de mate van opleiding van leraren om hun vak goed uit te oefenen (Figuur 4.10). Leraren en studenten zijn wederom het meest positief, positiever dan de Nederlandse bevolking, ouders en leerlingen. In het po zijn de scores over het algemeen iets hoger dan in het vo, in het vo iets hoger dan in het mbo. 
FIGUUR 4.10 Leraren in het [type onderwijs] zijn over het algemeen voldoende opgeleid om hun vak goed uit te oefenen

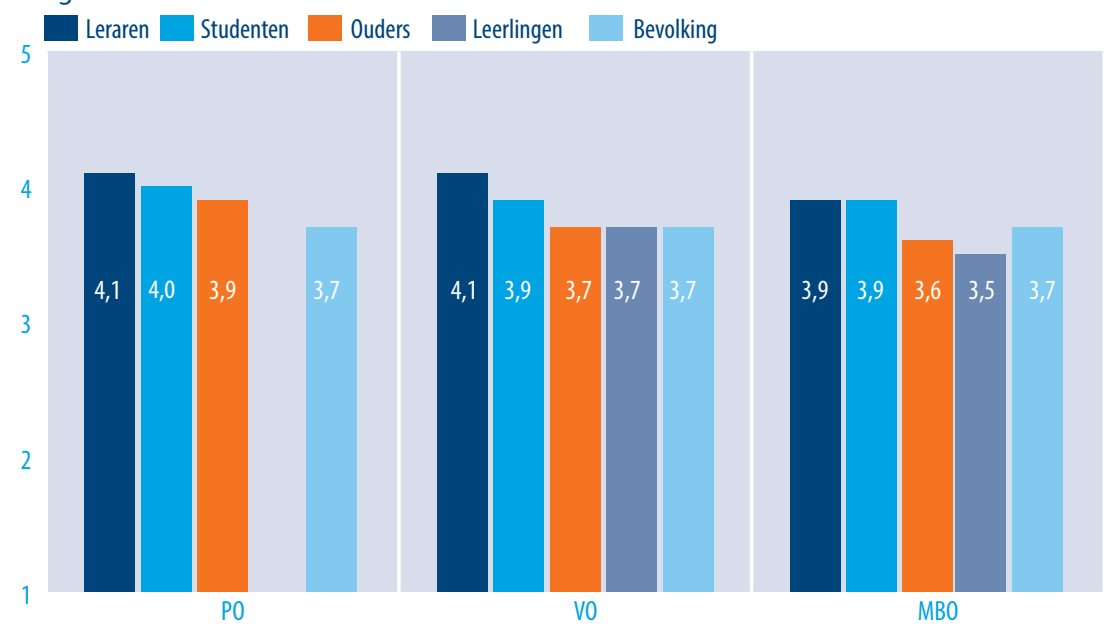

Leraren zijn het het meest eens met de uitspraak dat zij goed met ouders kunnen omgaan (Figuur 4.11). De laagste score voor deze uitspraak wordt gegeven door leerlingen in het mbo $(3,4)$ en de hoogste door leraren in het po. Studenten en leraren zijn het meest positief, significant positiever dan de andere groepen. In het po is men significant positiever dan in het vo en in het vo significant positiever dan in het mbo.

FIGUUR 4.11 Leraren in het [type onderwijs] kunnen over het algemeen goed met ouders omgaan

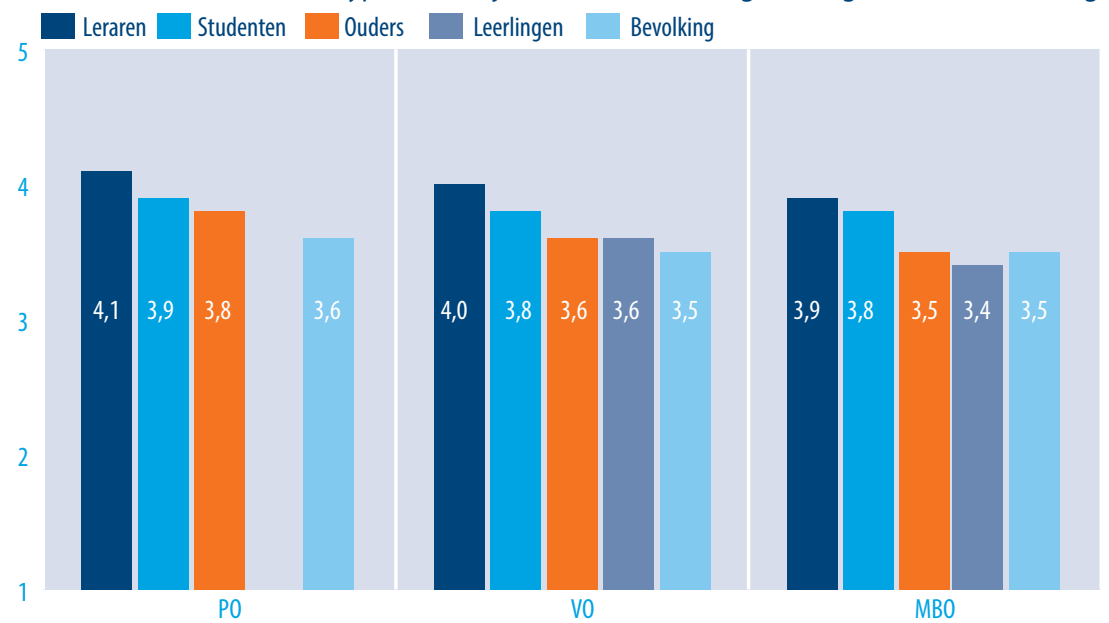

Respondenten zijn vrij positief over de omgang van leraren met kinderen / jongeren / leerlingen (Figuur 4.12). Studenten en leraren zijn het meest positief, gevolgd door de Nederlandse bevolking en ouders van leerlingen. Leerlingen zelf zijn significant negatiever dan al deze groepen over de omgang van leraren met kinderen / jongeren / leer- 
lingen. In het po zijn respondenten significant positiever dan in het vo, en in het vo positiever dan in het mbo.

FIGUUR 4.12 Leraren in het [type onderwijs] kunnen over het algemeen goed met kinderen/ jongeren/leerlingen omgaan

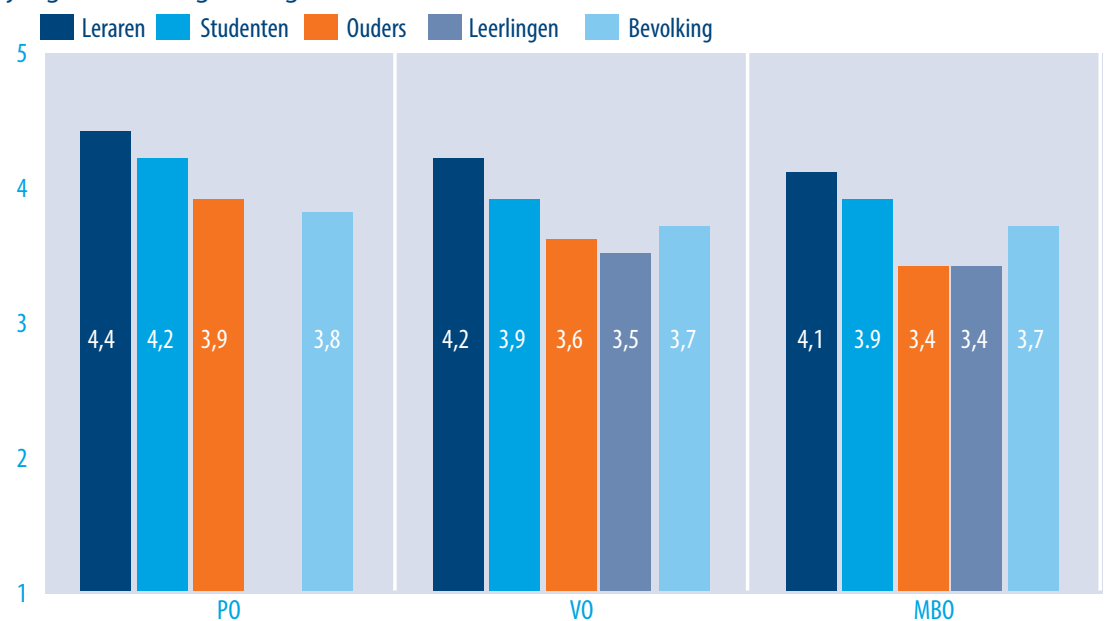

\section{Verschillen naar leeftijd, dienstjaren en geslacht}

We hebben ook voor de bovengenoemde variabelen de mening over de beroepsuitoefening van het vak van leraar uitgesplitst naar verschillende leeftijden voor leraren en de Nederlandse bevolking. Voor leraren zien we dat hoe ouder leraren zijn, hoe meer zij het eens zijn met de uitspraak dat leraren hun kennis en vaardigheden goed kunnen overbrengen aan leerlingen. Opvallend is dat vooral de groep leraren onder de 35 jaar het significant minder met deze stelling eens is dan leraren boven de 35 jaar.

Wat betreft de Nederlandse bevolking als totaal, zien we dat oudere respondenten over het algemeen positiever zijn dan jongere respondenten. Zij zijn significant positiever over de uitspraak dat leraren leerlingen goed kunnen motiveren en dat ze goed met leerlingen om kunnen gaan. Ook denken oudere respondenten vaker dat de Nederlandse bevolking het vak van leraar positief waardeert.

In het mbo en vo treden weinig verschillen op tussen leraren met meer of minder dienstjaren. In het po daarentegen, scoren leraren met een hoger aantal dienstjaren op bijna alle punten die gaan over beroepsuitoefening significant positiever dan hun collega's met minder dienstjaren.

Onder leraren zijn vrouwen positiever over de mate waarin leraren leerlingen kunnen motiveren. Voor de overige beroepsuitoefeningskenmerken vinden we geen verschillen tussen mannelijke en vrouwelijke leraren. Tussen mannelijke en vrouwelijke respondenten onder de Nederlandse bevolking treden meer verschillen op. Vrouwen zijn 
over het algemeen positiever dan mannen. Deze verschillen zijn significant voor de mate waarin leraren leerlingen kunnen motiveren, de mate waarin leraren voldoende opgeleid zijn om hun vak goed te kunnen uitoefenen en de mate waarin zij goed met kinderen om kunnen gaan.

\section{Verschillen naar school- en leraarkenmerken}

We hebben de antwoorden van leraren uitgesplitst naar de kenmerken van de scholen waarop zij lesgeven en de achtergrondkenmerken van de leraren. Voor schoolgrootte zien we voor po de volgende verschillen: leraren op scholen van boven de 300 leerlingen zijn significant positiever dan leraren op scholen tussen de 100 en 300 leerlingen over de mate waarin leraren kennis en vaardigheden kunnen overbrengen en de mate waarin leraren goed met ouders om kunnen gaan. Voor vo zien we hier geen verschillen. Voor het mbo zien we ook geen verschillen in type school (roc, aoc, vakschool of anders).

Leraren op po-scholen in een dorp of een kleine stad vinden vaker dan leraren in grote steden dat leraren voldoende opgeleid zijn om hun vak goed te kunnen uitoefenen. Leraren op mbo-scholen in een dorp of kleine stad vinden vaker dan leraren in een middelgrote stad dat leraren goed met ouders om kunnen gaan. Verder vinden leraren in zowel het vo als het mbo uit grote steden minder vaak dan leraren uit dorpen, kleine steden en middelgrote steden dat leraren hun kennis en vaardigheden goed kunnen overbrengen. De genoemde verschillen zijn significant.

Er zijn bijna geen verschillen tussen leraren in verschillende salarisschalen in de opvattingen die zij er op nahouden. Alleen voor leraren in het po zien we dat leraren in de salarisschaal LA positiever zijn dan leraren in salarisschaal LC als het gaat om de vakkennis die leraren hebben. Er treden geen significante verschillen op tussen leraren die algemeen vormende vakken, beroepsgerichte vakken of een combinatie daarvan geven betreffende de mening over de beroepsuitoefening. Leraren met een tweedegraads lerarenopleiding zijn over een aantal punten significant positiever dan leraren met een eerstegraads lerarenopleiding, namelijk over de mate waarin leraren voldoende vakkennis hebben (in het vo) en over de mate waarin leraren goed met ouders kunnen omgaan (in het mbo).

Als we kijken naar het aandeel achterstandsleerlingen op scholen, zien we dat er voor bijna alle variabelen verschillen optreden voor de leraren in het po: leraren van scholen met een percentage achterstandsleerlingen van minder dan 5 procent zijn positiever over de beroepsuitoefening door leraren dan leraren van scholen met een percentage achterstandsleerlingen van tussen de 5 en 25 procent. In het vo zien we hetzelfde effect voor drie van de zes gepresenteerde variabelen (overdragen van kennis en vaardigheden; het motiveren van leerlingen en de omgang met ouders). Voor het mbo zien we geen verschillen tussen de leraren van scholen met een verschillend aandeel achterstandsleerlingen. 


\section{Samenvattend}

Leraren zijn het meest positief over de mate waarin zij voldoende vakkennis hebben en over hun omgang met kinderen / jongeren / leerlingen. Van alle respondentgroepen scoren leraren significant positiever dan de andere respondentgroepen op alle uitspraken. Verder zijn leraren in het po vaak significant positiever dan leraren in het mbo. Leraren in het po met een hoger aantal dienstjaren zijn positiever dan hun collega's met een lager aantal dienstjaren.

Qua achtergrondkenmerken zien we dat leraren op scholen in dorpen en kleinere steden vaak positiever zijn over de beroepsuitoefening dan leraren op scholen in middelgrote en grote steden. Leraren uit het po en vo beoordelen de beroepsuitoefening negatiever naarmate er een hoger aandeel achterstandsleerlingen op de school zit. Voor het mbo maakt dit geen verschil.

Studenten aan de lerarenopleiding zijn het meest positief over de mate van vakkennis die leraren hebben. Studenten zijn - net als leraren - vaak significant positiever dan de andere respondentgroepen over de genoemde uitspraken. Studenten op de pabo zijn positiever dan andere respondentgroepen over de uitspraak dat leraren leerlingen goed kunnen motiveren en over de uitspraak dat leraren goed met kinderen / jongeren / leerlingen om kunnen gaan.

Ouders waarderen de vakkennis van leraren het meest (3,6 tot 4). Qua waardering voor de verschillende aspecten van het leraarschap zitten ze vaak tussen de uitersten van leraren (hoog) en leerlingen (laag) in. Ouders in het po scoren significant hoger op alle uitspraken dan ouders in het vo en mbo. Ouders die zelf leraar zijn (geweest) waarderen de beroepsuitoefening van leraren hoger dan ouders die geen leraar zijn (geweest).

Leerlingen zijn de meest negatieve groep, hoewel ze op alle uitspraken gemiddeld wel boven de 3 (neutraal) scoren. De meeste waardering hebben leerlingen voor de vakkennis die leraren hebben. Leerlingen in het vo zijn vaak significant positiever dan leerlingen in het mbo, vooral waar het gaat om vakkennis en de omgang met ouders.

De Nederlandse bevolking waardeert ook de vakkennis van leraren het hoogst, op gelijke hoogte als het overbrengen van kennis en vaardigheden en de omgang met jongeren / kinderen / leerlingen. Er zijn geen significante verschillen in de perceptie van de Nederlandse bevolking tussen de verschillende onderwijsvormen. Respondenten uit de Nederlandse bevolking die zelf leraar zijn (geweest), zijn vaak negatiever over de beroepsuitoefening van leraren dan andere respondenten uit de Nederlandse bevolking.

\subsection{Inschatting van het salaris van leraren}

We hebben aan studenten aan de lerarenopleiding, leerlingen en ouders een zestal hboberoepen voorgelegd met het bruto salaris dat daarbij hoort als er sprake is van een voltijdsbaan. In Figuur 4.13 is te zien dat alle respondentgroepen inschatten dat leraren 
het minst verdienen. Voor een leraar po schat het grootste gedeelte van de respondenten in dat hij of zij 2060 euro bruto per maand verdient; voor een leraar vo algemene vakken 2130 of 2360 euro per maand; voor een leraar vo beroepsgericht 2360 euro per maand. De overige beroepen worden vaak hoger ingeschat.

FIGUUR 4.13 Inschatting salaris 3 soorten leraren ten opzichte van andere beroepen (hbo-niveau)

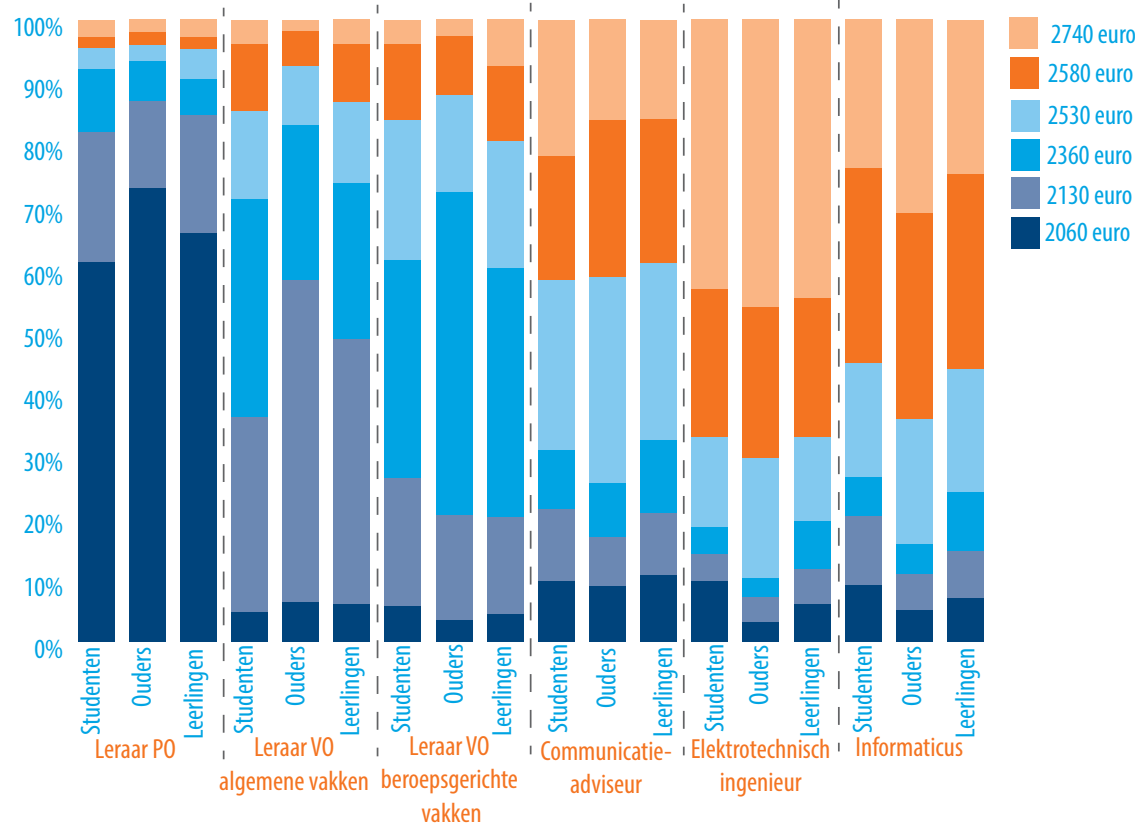

In Tabel 4.1 geven we het verschil in geschat versus daadwerkelijk salaris weer, per respondentgroep.

TABEL 4.1 Verschil in inschatting salaris, geschat minus werkelijk bruto salaris in een voltijdbaan

\begin{tabular}{|l|r|r|r|} 
& Studenten & Ouders & Leerlingen \\
\hline Leraar po & $€ 19,28$ & $€-4,40$ & $€ 12,87$ \\
\hline Leraar v0 avo & $€-403,47$ & $€-482,43$ & $€-438,66$ \\
\hline Leraar vo beroepsgericht & $€-204,51$ & $€-211,69$ & $€-179,36$ \\
\hline Communicatie-adviseur & $€ 418,19$ & $€ 428,43$ & $€ 405,28$ \\
\hline Elektrotechnisch ingenieur & $€ 32,38$ & $€ 73,23$ & $€ 41,24$ \\
\hline Informaticus & $€ 138,12$ & $€ 196,86$ & $€ 158,63$ \\
\hline
\end{tabular}

We zien dat het salaris van een leraar po vrij goed wordt ingeschat. Een leraar die op het voortgezet onderwijs in algemene vakken onderwijst, wordt te laag ingeschat, namelijk gemiddeld zo'n 450 euro te laag. Hetzelfde geldt voor een leraar die op het voortgezet onderwijs lesgeeft in beroepsgerichte vakken; die wordt gemiddeld 200 euro te laag 
ingeschat. De hbo-beroepen waar de leraren mee worden vergeleken worden door alle respondentgroepen te hoog ingeschat, communicatie-adviseurs zelfs meer dan 400 euro te hoog.

\subsection{Reflectie}

We hebben verschillende respondentgroepen gevraagd naar hun inschatting van de waardering voor het vak van leraar, de ontwikkeling daarvan over de tijd en de beroepsuitoefening van leraren. Leraren en studenten van de lerarenopleiding zijn het meest negatief over de waardering van hun beroep door ouders, leerlingen en de Nederlandse bevolking. Ouders en de Nederlandse bevolking zelf zijn hier significant positiever over. Geen enkele respondentgroep denkt dat de waardering voor leraren over de afgelopen 20 jaar is toegenomen. Leraren zijn hier wederom het meest negatief over.

Respondenten zijn vrij positief over de kwaliteiten van leraren. Leraren zijn hier, in tegenstelling tot hoe zij de waardering voor hun beroep inschatten, het meest positief over. Leerlingen zijn het minst positief. Ook zien we verschillen tussen de onderwijssectoren: respondenten die hun mening geven over het po zijn positiever dan respondenten die hun mening geven over het vo en mbo. Respondenten over het mbo zijn het meest negatief. Er zijn geen opvallende patronen waar te nemen als het gaat om verschillen in school- en lerarenkenmerken, behalve voor leeftijd. Oudere leraren schatten de waardering hoger in, evenals de waardering voor beroepsuitoefening.

Als we naar de ontwikkelingen over de tijd kijken, zien we een negatieve ontwikkeling in de inschatting van het beroep van leraar door leraren zelf. Het TALIS-onderzoek in 2013 onder leraren in de onderbouw van het vo geeft een positiever beeld over hoe leraren denken dat men aankijkt tegen het leraarschap, maar die resultaten laten zich moeilijk vergelijken met ons onderzoek. Respondenten uit alle groepen, vooral leraren, vinden dus dat over een periode van 20 jaar de waardering minder is geworden, hoewel een vergelijking met onderzoek uit 2008 een stijging laat zien.

De feitelijke beloning van leraren ligt hoger dan de meeste mensen denken, behalve voor po, dat wordt tamelijk goed ingeschat. De inschaling van leraren speelt nauwelijks rol in de waardering die leraren van anderen verwachten voor hun vak. We zien bovendien weinig verschillen in de opvattingen van leraren over hun vak tussen de salarisniveaus.

De waardering voor lerarenberoep wordt niet hoog ingeschat door leraren en studenten van de lerarenopleiding. Als het echter gaat om de kwaliteiten van leraren, zijn leraren en studenten van de lerarenopleiding daar juist weer significant positiever over. Hier treedt dus een spanningsveld op, waarin leraren vinden dat ze goed werk afleveren, dat in mindere mate gewaardeerd wordt door de samenleving. 



\section{IMAGO: BEROEPSPRESTIGE VERGELEKEN}

\section{$5.1 \quad$ Inleiding}

In dit hoofdstuk gaan we nader in op het imago of prestige van het beroep van leraar in vergelijking met andere beroepen. Binnen de sociologie is er traditioneel veel aandacht voor het thema ongelijkheid tussen groepen in de samenleving. Daarbij is in het verleden in Nederland ook enkele keren een ordening van beroepsbeoefenaren opgesteld op basis van het maatschappelijk aanzien dat zij genieten. Het maatschappelijk aanzien van beroepen wordt daarin voorgesteld als de treden van een beroepenladder waarop beroepen op verschillende sporten zijn gepositioneerd en daarmee dus minder of meer in aanzien staan. Driemaal is een dergelijke beroepenladder opgesteld. Halverwege de vorige eeuw (Van Heek et al., 1958), aan het begin van de jaren tachtig (Sixma en Ultee, 1983) en voor het laatst in 2006 (Groenewegen et al., 2007). Het gaat hier om drie min of meer vergelijkbare prestigemetingen waardoor ook vergelijkingen in de tijd mogelijk zijn. Daaruit wordt geconcludeerd dat er van een daling van het beroep van leraar op de beroepenladder nauwelijks sprake is.

In het kader van dit onderzoek naar status en imago van de leraar hebben we 10 jaar na de laatste meting opnieuw een beroepenladder geconstrueerd. Die is in de eerste plaats bedoeld om na te gaan wat anno 2016 het maatschappelijk aanzien van het beroep van leraar is ten opzichte van andere beroepen. Dat is vooral interessant omdat het inzicht geeft in de relatieve aantrekkingskracht van het beroep van leraar. In de tweede plaats zijn we uiteraard geïnteresseerd in hoeverre het beroep van leraar over de lange termijn van positie is veranderd ten opzichte van andere beroepen.

\subsection{Aanpak}

Dit specifieke onderzoeksonderdeel is uitgevoerd bij één van de vijf respondentgroepen uit het vorige hoofdstuk: de Nederlandse bevolking. De reden daarvoor is dat een afspiegeling van de samenleving nodig is voor het opstellen van een beroepenladder die iets zegt over het maatschappelijk aanzien van beroepen. De andere respondentgroepen zouden vanwege hun specifieke betrokkenheid met het beroep van leraar het maatschappelijk aanzien van de diverse beroepen naar verwachting sterk vertekenen. 
Net als bij eerdere metingen is respondenten gevraagd een aantal beroepen naar prestige te ordenen ${ }^{25}$. We hebben daarbij In totaal 138 beroepen onderscheiden. Dat zijn grotendeels dezelfde beroepen als die in 2006 gebruikt zijn (Groenewegen et al., 2007). Van enkele beroepen is de omschrijving licht gewijzigd en enkele zijn samengevoegd. In Tabel 5.1 geven we daarvan een overzicht. Het gaat om aanpassingen die ervoor zorgen dat de beroepen en benamingen aansluiten bij de situatie en het spraakgebruik in de huidige samenleving. In totaal 55 van de 138 beroepen zijn aangepast, 83 beroepen zijn ongewijzigd overgenomen. Bij de aanpassingen gaat het om het laten vervallen van beroepen omdat die nauwelijks nog in Nederland voorkomen ('machinaal wever in een textielfabriek'), het vervangen door een eigentijdser beroep ('eigenaar van een copyshop' in plaats van 'drukker'), het aanpassen van de benaming van beroepen ('onderwijzer op een basisschool' vervangen door 'leraar basisonderwijs), het sekseneutraal maken van benamingen ('kelner/serveerster' in plaats van 'kelner'), aanpassen aan wijzigingen in het beroep ('eigenaar van kiosk, met postafhaalpunt' in plaats van 'postkantoorhouder, beheerder bijkantoor'), het samenvoegen van beroepen (geen onderscheid meer tussen de omvang van gemeenten of ondernemingen voor respectievelijk burgemeester en directeuren) en soms het verduidelijken van beroepen door een toevoeging (toevoegen van 'onderhouden, bouwen, monteren en repareren van machines' bij 'machinebankwerker').

TABEL 5.1 Aanpassingen in lijst met beroepen

\begin{tabular}{|c|c|}
\hline 2006 & 2016 \\
\hline \multirow{2}{*}{$\begin{array}{l}\text { Ambtenaar, directeur openbare werken, gemeente } 80.000 \\
\text { inwoners }\end{array}$} & Directeur openbare werken bij gemeente \\
\hline & Werktuigbouwkundig ingenieur \\
\hline Kelner & Kelner/serveerster \\
\hline Leraar op het lager beroepsonderwijs & $\begin{array}{l}\text { Leraar vmbo en onderbouw havo/atheneum/gymnasium ( } 2 \mathrm{e} \\
\text { graads) }\end{array}$ \\
\hline \multirow{3}{*}{$\begin{array}{l}\text { Predikant } \\
\text { Pastoor }\end{array}$} & Pastoor/dominee \\
\hline & Schroldirecteur mbo \\
\hline & Schoordirecteur mo \\
\hline Landbouwer, zonder personeel, klein bedrijf & Agrariër land/tuinbouw, zonder personeel, klein bedrijf \\
\hline Tuinder & Hovenier \\
\hline Marktkoopman & Marktkoopman/vrouw \\
\hline \multirow[t]{2}{*}{ Ambtenaar, werkzaam op afdeling bevolking } & Gemeenteambtenaar op afdeling bevolking \\
\hline & Taxichauffeur \\
\hline \multicolumn{2}{|l|}{ Platenwalser in een staalfabriek } \\
\hline & Webdesigner \\
\hline $\begin{array}{l}\text { Burgemeester, gemeente met } 150.000 \text { inwoners } \\
\text { Burgemeester, gemeente met } 25.000 \text { inwoners }\end{array}$ & Burgemeester \\
\hline Leraar op een gymnasium & Leraar bovenbouw havo/atheneum/gymnasium (1e graads) \\
\hline
\end{tabular}

25 In 1982 ging het om een interviewer die beroepen met behulp van kaartjes aan de respondenten voorlegde met het verzoek die te ordenen, in 2006 hebben de respondenten de rangordening op een papieren vragenlijst zelf vastgelegd en in 2016 is dat gebeurd door respondenten via een online vragenlijst beroepen aan te bieden en te vragen via aanklikken de beroepen in een rangorde te zetten. 


\begin{tabular}{|c|c|}
\hline 2006 & 2016 \\
\hline $\begin{array}{l}\text { Directeur, industriële onderneming met } 50 \text { personeelsleden } \\
\text { Directeur, industriële onderneming met } 500 \text { personeelsleden }\end{array}$ & Directeur, industriële onderneming \\
\hline Chef loonadministratie bij een industriële onderneming & $\begin{array}{l}\text { Afdelingshoofd loonadministratie bij een industriële } \\
\text { onderneming }\end{array}$ \\
\hline Receptioniste & Receptionist(e)/telefonist(e) \\
\hline $\begin{array}{l}\text { Ingenieur, weg- en waterbouwkundige bij een } \\
\text { Ingenieursbureau }\end{array}$ & Weg- en waterbouwkundig ingenieur \\
\hline Computer-programmeur & Programmeur \\
\hline Manager van een hotel & Hotelmanager \\
\hline Glassorteerder in een glasfabriek & Medewerker aan de lopende band in fabriek \\
\hline Bloemenkweker & Bloemist \\
\hline \multirow[t]{2}{*}{ Strijkster in een wasserijbedrijf } & Medewerker strijkservice \\
\hline & Schooldirecteur vmbo/havo/vwo \\
\hline \multirow[t]{2}{*}{ Hoofd linnenkamer in een ziekenhuis } & Hoofd facilitaire dienst in een ziekenhuis \\
\hline & Campingeigenaar \\
\hline \multicolumn{2}{|l|}{ Akkerbouwer } \\
\hline Postkantoorhouder, beheerder bijkantoor & Eigenaar van kiosk, met postafhaalpunt \\
\hline Autobandenperser & Medewerker autowasstraat \\
\hline Bioloog, werkzaam op instituut voor visserij-onderzoek & Bioloog, werkzaam op een instituut voor milieu-onderzoek \\
\hline Bedieningsvakman in chemische industrie & $\begin{array}{l}\text { Procesoperator (bedienen van processen in de chemische } \\
\text { industrie) }\end{array}$ \\
\hline \multirow[t]{2}{*}{ Varkensfokker } & Varkenshouder \\
\hline & Automonteur \\
\hline \multicolumn{2}{|l|}{ Machinaal wever in een textielfabriek } \\
\hline \multirow[t]{2}{*}{ Internist } & $\begin{array}{l}\text { Internist (voorkomen, vaststellen en behandelen van ziekten } \\
\text { van inwendige organen van volwassen patiënt) }\end{array}$ \\
\hline & Schooldirecteur basisonderwijs \\
\hline \multicolumn{2}{|l|}{ Directeur van een handelsonderneming } \\
\hline Bedrijfseconoom & Management consultant \\
\hline Toneelspeler & Acteur \\
\hline Drukker & Eigenaar copyshop \\
\hline Bejaardenverzorgster & Verzorgende in dagopvang voor ouderen \\
\hline \multirow[t]{2}{*}{ Kamermeisje in een hotel } & Kamermeisje/jongen in een hotel \\
\hline & Medewerker facilitaire dienst \\
\hline \multicolumn{2}{|l|}{ Arbeider in melkfabriek } \\
\hline Verkeersvlieger bij een luchtvaartmaatschappij & Verkeersvlieger bij een luchtvaartmaatschappij (piloot) \\
\hline Landbouwer, alleen leidinggevend, groot bedrijf & Agrariër land/tuinbouw, alleen leidinggevend, groot bedrijf \\
\hline \multirow[t]{2}{*}{ Telefoniste } & Call centre medewerker \\
\hline & Leraar mbo \\
\hline \multicolumn{2}{|l|}{ Boormeester op een olieplatform } \\
\hline Radioloog & $\begin{array}{l}\text { Radioloog (vaststellen van ziektes door röntgenonderzoek, } \\
\text { scans of echo's) }\end{array}$ \\
\hline Voetbaltrainer & Hoofdtrainer profvoetbal \\
\hline Assistent in laboratorium voor plantenziekten & Laboratoriumassistent \\
\hline Hoofdverpleegkundige in de zwakzinnigenzorg & $\begin{array}{l}\text { Hoofdverpleegkundige in instelling voor verstandelijk } \\
\text { gehandicapten }\end{array}$ \\
\hline
\end{tabular}




\begin{tabular}{|l|l|}
\hline 2006 & 2016 \\
\hline Keuringsambtenaar IJkwezen & $\begin{array}{l}\text { Keuringsambtenaar IJkwezen (controleren van } \\
\text { meetinstrumenten) }\end{array}$ \\
\hline Productiemedewerker in een papierfabriek & $\begin{array}{l}\text { Productiemedewerker bij een industriële onderneming } \\
\text { Vuilnisman }\end{array}$ \\
\hline Onderwijzer op een basisschool & Leraar basisonderwijs \\
\hline Machinebankwerker & $\begin{array}{l}\text { Machinebankwerker (onderhouden, bouwen, monteren en } \\
\text { repareren van machines) }\end{array}$ \\
\hline
\end{tabular}

Uit de beroepenlijst van 138 beroepen is steeds een deelverzameling van 28 beroepen aan de respondentgroepen voorgelegd. Daarbij is een set van 6 ankerberoepen aan iedereen voorgelegd en een wisselende set van 22 beroepen aan afzonderlijke deelpopulaties van de respondenten. Dat totaal van 22 bestond uit twee sets van 11 steeds vaste combinaties van beroepen. In totaal waren er 12 van dergelijke sets plus de set van 6 ankerberoepen, wat optelt tot 138 beroepen.

Daarmee sluiten we bij de werkwijze van zowel Groenewegen et al., 2007) als Sixma en Ultee (1983). Aan de respondenten is gevraagd de 28 beroepen te ordenen naar maatschappelijke status. De tekst daarvoor luidde:

"We willen u vragen om de onderstaande beroepen op een beroepenladder te zetten naar maatschappelijk aanzien. Het gaat hierbij niet om het aanzien zoals u dit zelf aan de beroepen zou toekennen, maar om het aanzien zoals men er in het algemeen over denkt. Het beroep dat in de maatschappij het meeste aanzien heeft, wat het hoogst staat aangeschreven, komt bovenaan op de beroepenladder te staan; het beroep dat het minste aanzien heeft, komt onderaan de ladder."

Deze zogenaamde projectieve vraagstelling is gangbaar in het onderzoek naar prestige en wordt vooral toegepast om te voorkomen dat respondenten antwoorden met "iedereen is voor mij gelijk" of soortgelijke uitspraken. Dat zijn in de regel sociaal-wenselijke antwoorden. De projectieve vraagstelling blijkt goed te werken in eerder metingen en weerspiegelt het beeld zoals dat in de maatschappij bestaat (Sixma en Ultee, 1983: blz. 366).

In bijlage III staat een overzicht van de aantallen respondenten per set van beroepencombinaties. Uiteindelijk is iedere set van beroepen op maatschappelijk aanzien beoordeeld door tussen de 149 en 191 respondenten. De 6 ankerberoepen zijn door alle 1019 respondenten beoordeeld. Bij de ankerberoepen gaat het om: tandarts, leraar basisonderwijs, slager (eigenaar slagerij) machinebankwerker (onderhouden, bouwen, monteren en repareren van machines), treinconducteur en vuilnisophaler. 


\subsection{Beroepsprestigeladder}

Voor het opstellen van de beroepenladder hebben we gebruik gemaakt van de methodiek van Successive Intervals Scaling (SSI) die geschikt is voor het omzetten van ordinale gegevens naar een lineaire schaal (Edwards en Gonzalez, 1993). Deze techniek is ook voor de constructie van de voorgaande beroepenladders gebruikt. De essentie is dat we de rangorde die de individuele respondenten geven aan de hen voorgelegde set van beroepen, op macroniveau kunnen omzetten in een schaal waarbij niet alleen de ordening ontstaat maar ook de afstanden tussen de beroepen berekend kunnen worden.

De basis daarvoor is steeds de proportie respondenten die een specifiek beroep vanaf een bepaalde positie in de rangordening van de 28 voorgelegde beroepen plaatst. Op basis van deze cumulatieve proporties kunnen de afstanden tussen de 28 posities, de schaalwaarden en de posities van de beroepen op een metrische schaal worden bepaald. Edwards en Gonzalez (1993) lichten dit nader toe en we hebben hun werkwijze gevolgd.

Dat leidt tot een beroepsprestigeschaal zoals gepresenteerd in Tabel 5.2. In de eerste kolom staat de positie van het beroep op de totale rangordening. Het beroep van chirurg wordt het meeste maatschappelijke aanzien toegekend (op positie 1) en het beroep van vuilnisophaler het minste (op positie 138). In de derde kolom staat de bijbehorende score op de schaal van de beroepenladder. Die loopt van o tot en met 5,57. Daaruit is er nog een relatieve score berekend (in de vierde kolom) zodat duidelijk wordt hoe dicht een beroep bij de top van de schaal zit. Als die $100 \%$ bedraagt dan zit een beroep aan de top en als die o\% bedraagt, bevindt een beroep zich helemaal aan de onderkant van de schaal.

TABEL 5.2 Beroepsprestigeschaal 2016

\begin{tabular}{|l|l|r|r|}
\hline Ordening & Beroep & $\begin{array}{r}\text { Schaalscore op } \\
\text { ladder }\end{array}$ & $\begin{array}{r}\text { Relatieve } \\
\text { schaalscore }\end{array}$ \\
\hline 1 & chirurg & 0,05 & 99,04 \\
\hline 2 & rechter & 0,11 & 97,96 \\
\hline 3 & burgemeester & 0,13 & 97,58 \\
\hline 4 & internist (voorkomen, vaststellen en behandelen van ziekten van & \\
\hline 5 & inwendige organen van volwassen patiënt) & 0,29 & 94,82 \\
\hline 6 & advocaat & 0,39 & 93,05 \\
\hline 7 & directeur, industriële onderneming & 0,65 & 88,34 \\
\hline 8 & notaris & 0,67 & 88,03 \\
\hline 9 & verkeersvlieger bij een luchtvaartmaatschappij (piloot) & 0,69 & 87,63 \\
\hline 10 & huisarts, zelfstandig gevestigd & 0,72 & 87,06 \\
\hline 11 & hoogleraar & 0,73 & 86,95 \\
\hline 12 & radioloog (vaststellen van ziektes door röntgenonderzoek, scans) & 0,76 & 86,27 \\
\hline 13 & commissaris van politie & 0,82 & 85,32 \\
\hline 14 & weg- en waterbouwkundig ingenieur & 1,09 & 80,41 \\
\hline 15 & commandant bij de brandweer & 1,23 & 77,99 \\
\hline
\end{tabular}




\begin{tabular}{|c|c|c|c|}
\hline Ordening & Beroep & $\begin{array}{r}\text { Schaalscore op } \\
\text { ladder }\end{array}$ & $\begin{array}{l}\text { Relatieve } \\
\text { schaalscore }\end{array}$ \\
\hline 16 & medisch analist & 1,25 & 77,51 \\
\hline 17 & tandarts & 1,26 & 77,33 \\
\hline 18 & apotheker & 1,26 & 77,29 \\
\hline 19 & dierenarts, zelfstandig gevestigd & 1,38 & 75,15 \\
\hline 20 & beroepsmilitair, kolonel bij het leger & 1,40 & 74,90 \\
\hline 21 & schooldirecteur vmbo/havo/vwo & 1,48 & 73,44 \\
\hline 22 & chemicus, werkzaam op een laboratorium & 1,50 & 73,05 \\
\hline 23 & psychotherapeut & 1,50 & 73,02 \\
\hline 24 & bioloog, werkzaam op een instituut voor milieu-onderzoek & 1,54 & 72,37 \\
\hline 25 & profvoetballer & 1,55 & 72,19 \\
\hline 26 & werktuigbouwkundig ingenieur & 1,56 & 72,07 \\
\hline 27 & accountant, medewerker op een accountantskantoor & 1,59 & 71,46 \\
\hline 28 & filiaalhouder van een bank & 1,61 & 71,08 \\
\hline 29 & fysiotherapeut & 1,64 & 70,63 \\
\hline 30 & hoofdverpleegkundige in instelling voor verstandelijk gehandicapten & 1,69 & 69,63 \\
\hline 31 & hotelmanager & 1,69 & 69,60 \\
\hline 32 & schooldirecteur basisonderwijs & 1,70 & 69,56 \\
\hline 33 & hoofdtrainer profvoetbal & 1,70 & 69,50 \\
\hline 34 & makelaar & 1,78 & 68,02 \\
\hline 35 & programmeur & 1,79 & 67,86 \\
\hline 36 & management consultant & 1,79 & 67,79 \\
\hline 37 & afdelingshoofd loonadministratie bij een industriële onderneming & 1,83 & 67,12 \\
\hline 38 & schooldirecteur mbo & 1,85 & 66,76 \\
\hline 39 & bedrijfsarts & 1,86 & 66,53 \\
\hline 40 & hoofd facilitaire dienst in een ziekenhuis & 1,87 & 66,46 \\
\hline 41 & verloskundige & 1,87 & 66,42 \\
\hline 42 & verpleegkundige & 1,91 & 65,69 \\
\hline 43 & leraar bovenbouw havo/atheneum/gymnasium (1e graads) & 1,94 & 65,18 \\
\hline 44 & directeur openbare werken bij gemeente & 1,99 & 64,33 \\
\hline 45 & pastoor/dominee & 2,03 & 63,55 \\
\hline 46 & beroepsmilitair, sergeant bij het leger & 2,08 & 62,68 \\
\hline 47 & politieagent & 2,14 & 61,64 \\
\hline 48 & acteur & 2,17 & 60,96 \\
\hline 49 & web designer & 2,18 & 60,77 \\
\hline 50 & leraar vmbo en onderbouw havo/atheneum/gymnasium (2e graads) & 2,23 & 59,96 \\
\hline 51 & effectenhandelaar & 2,24 & 59,69 \\
\hline 52 & nieuwslezer bij de radio & 2,27 & 59,23 \\
\hline 53 & vakbondsbestuurder & 2,29 & 58,92 \\
\hline 54 & inspecteur milieuwetgeving & 2,30 & 58,69 \\
\hline 55 & goud- en zilversmid & 2,34 & 58,06 \\
\hline 56 & netwerkbeheerder & 2,36 & 57,55 \\
\hline 57 & bedrijfsvoorlichter & 2,37 & 57,53 \\
\hline 58 & journalist & 2,37 & 57,41 \\
\hline 59 & leraar mbo & 2,38 & 57,29 \\
\hline
\end{tabular}




\begin{tabular}{|c|c|c|c|}
\hline Ordening & Beroep & $\begin{array}{l}\text { Schaalscore op } \\
\text { ladder }\end{array}$ & $\begin{array}{l}\text { Relatieve } \\
\text { schaalscore }\end{array}$ \\
\hline 60 & procesoperator (bedienen van processen in de chemische industrie) & 2,39 & 57,08 \\
\hline 61 & elektricien, eigenaar elektrotechnisch bedrijf & 2,39 & 57,00 \\
\hline 62 & maatschappelijk werker & 2,41 & 56,75 \\
\hline 63 & directiesecretaresse & 2,42 & 56,63 \\
\hline 64 & technisch tekenaar & 2,44 & 56,15 \\
\hline 65 & bedrijfsleider van een café-restaurant & 2,45 & 56,03 \\
\hline 66 & douane-ambtenaar & 2,46 & 55,89 \\
\hline 67 & laboratoriumassistent & 2,50 & 55,04 \\
\hline 68 & verzekeringsagent & 2,53 & 54,66 \\
\hline 69 & leraar basisonderwijs & 2,53 & 54,48 \\
\hline 70 & boekhouder & 2,54 & 54,45 \\
\hline 71 & secretaresse & 2,55 & 54,23 \\
\hline 72 & begrafenisondernemer & 2,58 & 53,66 \\
\hline 73 & bedrijfsleider in een supermarkt & 2,59 & 53,47 \\
\hline 74 & geluidstechnicus bij een omroeporganisatie & 2,61 & 53,09 \\
\hline 75 & kok & 2,64 & 52,55 \\
\hline 76 & winkelier, zelfstandig in aardappelen, groente \& fruit & 2,66 & 52,32 \\
\hline 77 & slager, eigenaar slagerij & 2,71 & 51,41 \\
\hline 78 & keuringsambtenaar ijkwezen (controleren van meetinstrumenten) & 2,71 & 51,28 \\
\hline 79 & bibliothecaris, openbare bibliotheek & 2,73 & 50,94 \\
\hline 80 & kraamverzorgende & 2,75 & 50,68 \\
\hline 81 & agrariër land/tuinbouw, alleen leidinggevend, groot bedrijf & 2,75 & 50,64 \\
\hline 82 & ploegbaas in metaalconstructiebedrijf & 2,88 & 48,36 \\
\hline 83 & kapper, eigenaar kapsalon & 2,91 & 47,76 \\
\hline 84 & tandarts-assistente & 2,92 & 47,60 \\
\hline 85 & boswachter & 2,94 & 47,30 \\
\hline 86 & docent lichamelijke opvoeding & 2,94 & 47,24 \\
\hline 87 & acupuncturist, die geen arts is & 2,98 & 46,41 \\
\hline 88 & eigenaar van kiosk, met postafhaalpunt & 3,00 & 46,14 \\
\hline 89 & campingeigenaar & 3,01 & 45,88 \\
\hline 90 & agrariër landltuinbouw, zonder personeel, klein bedrijf & 3,05 & 45,27 \\
\hline 91 & eigenaar copyshop & 3,05 & 45,21 \\
\hline 92 & verzorgende in dagopvang voor ouderen & 3,06 & 45,05 \\
\hline 93 & gemeenteambtenaar op afdeling bevolking & 3,06 & 45,05 \\
\hline 94 & scheepsmachinist op een visserijschip & 3,06 & 45,05 \\
\hline 95 & fijnmetaalbewerker & 3,06 & 44,99 \\
\hline 96 & melkveehouder & 3,14 & 43,63 \\
\hline 97 & automonteur & 3,15 & 43,43 \\
\hline 98 & gevangenenbewaarder & 3,23 & 41,95 \\
\hline 99 & meubelmaker in een meubelfabriek & 3,24 & 41,81 \\
\hline 100 & caféhouder & 3,25 & 41,55 \\
\hline 101 & leerling-verpleegkundige & 3,30 & 40,78 \\
\hline 102 & $\begin{array}{l}\text { machinebankwerker (onderhouden, bouwen, monteren en repareren } \\
\text { van machines) }\end{array}$ & 3,33 & 40,23 \\
\hline
\end{tabular}




\begin{tabular}{|c|c|c|c|}
\hline Ordening & Beroep & $\begin{array}{r}\text { Schaalscore op } \\
\text { ladder }\end{array}$ & $\begin{array}{l}\text { Relatieve } \\
\text { schaalscore }\end{array}$ \\
\hline 103 & hovenier & 3,33 & 40,15 \\
\hline 104 & treinconducteur & 3,35 & 39,78 \\
\hline 105 & kunstschilder & 3,43 & 38,47 \\
\hline 106 & receptionist(e)/telefonist(e) & 3,55 & 36,30 \\
\hline 107 & bloemist & 3,56 & 36,00 \\
\hline 108 & medewerker facilitaire dienst & 3,58 & 35,67 \\
\hline 109 & meubelstoffeerder & 3,59 & 35,49 \\
\hline 110 & schoolconciërge & 3,61 & 35,15 \\
\hline 111 & lasser & 3,66 & 34,35 \\
\hline 112 & metselaar & 3,68 & 33,97 \\
\hline 113 & huisschilder & 3,70 & 33,50 \\
\hline 114 & beheerder van een buurthuis & 3,76 & 32,52 \\
\hline 115 & buschauffeur, lijndienst & 3,76 & 32,52 \\
\hline 116 & productiemedewerker bij een industriële onderneming & 3,80 & 31,77 \\
\hline 117 & varkenshouder & 3,82 & 31,36 \\
\hline 118 & postbode & 3,84 & 31,10 \\
\hline 119 & vrachtwagenchauffeur & 3,85 & 30,92 \\
\hline 120 & bulldozermachinist & 3,89 & 30,18 \\
\hline 121 & huishoudelijke hulp bij de thuiszorg & 3,93 & 29,41 \\
\hline 122 & kelner/serveerster & 3,99 & 28,44 \\
\hline 123 & stadswacht & 4,05 & 27,34 \\
\hline 124 & taxichauffeur & 4,08 & 26,66 \\
\hline 125 & winkelbediende & 4,15 & 25,46 \\
\hline 126 & marktkoopman/vrouw & 4,16 & 25,39 \\
\hline 127 & arbeider, land- of tuinbouw & 4,17 & 25,17 \\
\hline 128 & magazijnbediende & 4,18 & 24,86 \\
\hline 129 & call centre medewerker & 4,42 & 20,72 \\
\hline 130 & glazenwasser & 4,52 & 18,78 \\
\hline 131 & schoorsteenveger & 4,53 & 18,71 \\
\hline 132 & medewerker autowasstraat & 4,66 & 16,32 \\
\hline 133 & kamermeisje/jongen in een hotel & 4,72 & 15,27 \\
\hline 134 & bijrijder op een vrachtwagen & 4,73 & 15,01 \\
\hline 135 & medewerker strijkservice & 4,74 & 14,81 \\
\hline 136 & kaartverkoper in een pretpark & 4,78 & 14,20 \\
\hline 137 & medewerker aan de lopende band in fabriek & 4,89 & 12,27 \\
\hline 138 & vuilnisophaler & 5,36 & 3,82 \\
\hline
\end{tabular}

We concentreren ons eerst op de diverse vormen van het beroep van leraar op de totale ladder (met oranje aangegeven). Er zijn vier reguliere lerarenberoepen opgenomen: leraar voortgezet onderwijs eerste graad, leraar voortgezet onderwijs tweede graad, leraar middelbaar beroepsonderwijs en leraar basisonderwijs. De beroepen zijn ook in deze aflopende volgorde gescoord op maatschappelijk aanzien. Er is nog de specifieke categorie 'docent lichamelijke opvoeding'. Deze vakleerkracht wordt minder aanzien 
toegedicht dan de leraar basisonderwijs. Leraren in het eerstegraadsgebied genieten duidelijk het meeste aanzien, leraren in het basisonderwijs aanmerkelijk minder. Dat weerspiegelt waarschijnlijk het verschil in de benodigde opleiding en het salaris voor beide beroepen.

De vier reguliere lerarenberoepen liggen redelijk dicht bij elkaar in de buurt, van positie 43 tot 69 . Dat komt overeen met relatieve scores van respectievelijk 65,2 en 54,5 en daarmee nemen de lerarenberoepen een range van 10 à $11 \%$ in op de totale beroepenladder. Die beroepen bevinden zich rond een relatieve schaalscore van 60, dus dat betekent dat ze zich (net) aan de positieve kant van het scala aan beroepen bevinden als het gaat om maatschappelijk aanzien. Desondanks gaat het in het onderwijs dus zeker niet om beroepen met veel maatschappelijk aanzien.

De leraar in het eerstegraadsgebied van het voortgezet onderwijs beweegt zich qua aanzien in de kringen van verpleegkundigen, verloskundigen, directiefuncties bij de gemeente en/of onderofficieren. Leraren basisonderwijs worden meer geplaatst bij beroepen als verzekeringsagent, secretaresse, laboratoriumassistent en boekhouder. We zien verder dat leraren zich qua aanzien niet kunnen meten met professies zoals advocaten, notarissen, medisch analisten, apothekers, en psycho- of fysiotherapeuten.

De directiefuncties in het onderwijs wordt een hoger maatschappelijk aanzien toegedicht dan de lerarenfuncties. Opvallend daarbij is overigens dat schooldirecteuren in het mbo minder aanzien wordt toegedicht dan directeuren in het basisonderwijs. Gezien de omvang en complexiteit van mbo-instellingen in vergelijking met het basisonderwijs en de daarmee gepaard gaande verantwoordelijkheid van de directie zou een andere ordening voor de hand hebben gelegen.

Voor het overige laat de volgorde van beroepen op de ladder zien dat, wat ook uit eerdere studies bekend is, het opleidingsniveau dat nodig is voor uitoefening voor een beroep en het inkomen dat mensen met het beroep verwerven, in grote lijnen de positie op de ladder bepalen. Over het algemeen staan de beroepen die goed betalen en waarvoor een universitaire studie nodig is bovenaan, gevolgd door de beroepen waarvoor een hbo-opleiding is vereist met een wat lager salaris dan bij academici, enzovoorts. Onderaan op de ladder staan de beroepen waarvoor nauwelijks of helemaal geen opleiding vereist is en waarbij over het algemeen een laag salaris hoort. De profvoetballer op positie 25 compenseert hier waarschijnlijk met zijn salaris de relatieve lage opleidingsvereisten vergeleken met beroepen bij hem in de buurt (bijvoorbeeld accountant, ingenieur, psychotherapeut).

\subsection{Vergelijking met eerdere ladders}

In 1982 hebben Sixma en Ultee (1983) hun beroepsprestigeschaal geconstrueerd en in 2006 is dat onderzoek door Groenwegen et al. (2007) gerepliceerd. Toen is een aantal conclusies getrokken over de ontwikkeling in het aanzien van het lerarenberoep: 
"Hoewel dergelijke ontwikkelingen aanleiding geven tot de gedachte dat het aanzien van beroepen in het onderwijs in de laatste decennia is gedaald, blijkt dit op basis van deze studie hooguit maar ten dele op te gaan. Zo is de leraar op een gymnasium weliswaar 5 plekken in haar rangorde gedaald, maar bedraagt deze daling voor de leraar op het lager beroepsonderwijs maar 1 plek, terwijl de onderwijzer op een basisschool in rangorde gelijk is gebleven (tabel 5.3). Van een algemene sterke daling in aanzien van de leraar is dus geen sprake." We zijn uiteraard erg geïnteresseerd of deze conclusie over de periode 1982 tot en met 2006 in de afgelopen 10 jaar wordt bevestigd of dat er nu andere bewegingen hebben plaatsgevonden.

Voordat we ingaan op de inhoudelijke vergelijking geven we eerst informatie over de mate waarin de instrumenten goed vergelijkbaar zijn. We hebben de schalen uit 2016, 2006 en 1982 onderling vergeleken door de beroepen te selecteren die op alle drie de schalen voorkomen waarbij we ons niet beperken tot de exacte omschrijving maar ook beroepen meenemen met aanpassingen in werkinhoud en/of benaming. Dat leidt tot een lijst van 95 (van de 138) beroepen.

Voor de vergelijking van de schaalposities hebben we gebruikt gemaakt van de relatieve schaalscores, die in alle drie ladders in theorie lopen van o (laagst mogelijke aanzien) tot 100 (hoogst mogelijke aanzien). Op basis van de correlaties van de schaalscores concluderen we dat in grote lijnen in het maatschappelijk aanzien van beroepen geen grote verschuivingen hebben plaatsgevonden. De correlatie tussen de schaalscores van de 95 vergelijkbare beroepen bedraagt tussen 2006 en 2016 0,96 en tussen 2016 en 1982 0,95. Kortom, de rangordening van de beroepen op de schalen is zeer consistent in de loop van de tijd. We geven in onderstaande tabel een overzicht van de posities en de relatieve schaalscores per studie.

TABEL 5.3 Vergelijking Beroepsprestigeschaal 2016 met eerdere schalen

\begin{tabular}{|c|c|c|c|c|c|c|c|}
\hline Beroep 2016 & Trend & $\begin{array}{r}\text { Schaal } \\
2016\end{array}$ & $\begin{array}{r}\text { Positie } \\
2016\end{array}$ & $\begin{array}{r}\text { Schaal } \\
2006\end{array}$ & $\begin{array}{r}\text { Positie } \\
2006\end{array}$ & $\begin{array}{r}\text { Schaal } \\
1982\end{array}$ & $\begin{array}{r}\text { Positie } \\
1982\end{array}$ \\
\hline chirurg & $\boldsymbol{\Delta}$ & 99,0 & 1 & 94,8 & 1 & 91,1 & 1 \\
\hline rechter & $\boldsymbol{\Delta}$ & 98,0 & 2 & 94,6 & 2 & 89,9 & 2 \\
\hline burgemeester & $\boldsymbol{\Delta}$ & 97,6 & 3 & 92,5 & 3 & 88,1 & 5 \\
\hline advocaat & $\boldsymbol{\Delta}$ & 93,1 & 5 & 87,1 & 9 & 85,4 & 9 \\
\hline directeur, industriële onderneming & $\boldsymbol{\Delta}$ & 88,3 & 6 & 87,5 & 7 & 83,6 & 10 \\
\hline notaris & & 88,0 & 7 & 84,9 & 11 & 85,9 & 8 \\
\hline $\begin{array}{l}\text { verkeersvlieger bij een luchtvaartmaatschappij } \\
\text { (piloot) }\end{array}$ & & 87,6 & 8 & 80,1 & 13 & 81,7 & 12 \\
\hline huisarts, zelfstandig gevestigd & & 87,1 & 9 & 86,2 & 10 & 86,3 & 7 \\
\hline hoogleraar & & 86,9 & 10 & 89,4 & 5 & 88,4 & 4 \\
\hline commissaris van politie & & 85,3 & 12 & 87,8 & 6 & 81,2 & 13 \\
\hline weg- en waterbouwkundig ingenieur & & 80,4 & 13 & 85,2 & 12 & 82,6 & 11 \\
\hline commandant bij de brandweer & $\boldsymbol{\Delta}$ & 78,0 & 14 & 71,6 & 23 & 61,5 & 34 \\
\hline architect, zelfstandig gevestigd & & 77,9 & 15 & 80 & 14 & 70,4 & 21 \\
\hline medisch analist & & 77,5 & 16 & 70,6 & 26 & 63,3 & 29 \\
\hline
\end{tabular}




\begin{tabular}{|c|c|c|c|c|c|c|c|}
\hline Beroep 2016 & Trend & $\begin{array}{r}\text { Schaal } \\
2016\end{array}$ & $\begin{array}{r}\text { Positie } \\
2016\end{array}$ & $\begin{array}{r}\text { Schaal } \\
2006\end{array}$ & $\begin{array}{r}\text { Positie } \\
2006\end{array}$ & $\begin{array}{r}\text { Schaal } \\
1982\end{array}$ & $\begin{array}{r}\text { Positie } \\
1982\end{array}$ \\
\hline tandarts & $\nabla$ & 77,3 & 17 & 79,8 & 15 & 80,9 & 14 \\
\hline apotheker & $\Delta$ & 77,3 & 18 & 75,1 & 18 & 69,7 & 22 \\
\hline dierenarts, zelfstandig gevestigd & & 75,2 & 19 & 73,7 & 20 & 78,3 & 15 \\
\hline beroepsmilitair, kolonel bij het leger & & 74,9 & 20 & 71,6 & 24 & 75,3 & 18 \\
\hline chemicus, werkzaam op een laboratorium & & 73,1 & 22 & 67,2 & 28 & 65,8 & 28 \\
\hline $\begin{array}{l}\text { bioloog, werkzaam op een instituut voor } \\
\text { milieu-onderzoek }\end{array}$ & & 72,4 & 24 & 66,2 & 29 & 69,4 & 23 \\
\hline profvoetballer & $\boldsymbol{\Delta}$ & 72,2 & 25 & 59,9 & 40 & 51,0 & 55 \\
\hline $\begin{array}{l}\text { accountant, medewerker op een } \\
\text { accountantskantoor }\end{array}$ & & 71,5 & 27 & 62,7 & 33 & 66,6 & 25 \\
\hline filiaalhouder van een bank & & 71,1 & 28 & 71,4 & 25 & 61,0 & 36 \\
\hline hotelmanager & & 69,6 & 31 & 73,1 & 21 & 66,2 & 26 \\
\hline makelaar & & 68,0 & 34 & 61,9 & 35 & 63,1 & 30 \\
\hline programmeur & & 67,9 & 35 & 64,7 & 30 & 66,0 & 27 \\
\hline management consultant & & 67,8 & 36 & 79,0 & 16 & 73,0 & 19 \\
\hline $\begin{array}{l}\text { afdelingshoofd loonadministratie bij een } \\
\text { industriële onderneming }\end{array}$ & $\Delta$ & 67,1 & 37 & 63,7 & 32 & 62,8 & 32 \\
\hline hoofd facilitaire dienst in een ziekenhuis & & 66,5 & 40 & 35,8 & 77 & 37,7 & 77 \\
\hline verpleegkundige & $\Delta$ & 65,7 & 42 & 53,5 & 50 & 51,6 & 54 \\
\hline $\begin{array}{l}\text { leraar bovenbouw havo/atheneum/gymnasium } \\
\text { (1e graads) }\end{array}$ & $\nabla$ & 65,2 & 43 & 72,6 & 22 & 76,1 & 17 \\
\hline pastoor/dominee & $\nabla$ & 63,6 & 45 & 68,1 & 27 & 68,4 & 24 \\
\hline beroepsmilitair, sergeant bij het leger & $\boldsymbol{\Delta}$ & 62,7 & 46 & 57,5 & 44 & 55,1 & 44 \\
\hline politieagent & $\Delta$ & 61,6 & 47 & 59,6 & 41 & 52,1 & 50 \\
\hline acteur & & 61,0 & 48 & 41,7 & 67 & 44,0 & 65 \\
\hline $\begin{array}{l}\text { leraar vmbo en onderbouw havolatheneuml } \\
\text { gymnasium ( } 2 \text { e graads) }\end{array}$ & $\nabla$ & 60,0 & 50 & 62,2 & 34 & 62,6 & 33 \\
\hline nieuwslezer bij de radio & & 59,2 & 52 & 46,7 & 62 & 52,0 & 51 \\
\hline vakbondsbestuurder & & 58,9 & 53 & 61,1 & 37 & 60,1 & 40 \\
\hline goud- en zilversmid & & 58,1 & 55 & 55,7 & 46 & 60,1 & 39 \\
\hline netwerkbeheerder & & 57,5 & 56 & 60,3 & 39 & 60,0 & 41 \\
\hline journalist & $\nabla$ & 57,4 & 58 & 57,9 & 43 & 60,8 & 37 \\
\hline $\begin{array}{l}\text { procesoperator (bedienen van processen in de } \\
\text { chemische industrie) }\end{array}$ & $\Delta$ & 57,1 & 60 & 38,4 & 73 & 37,8 & 75 \\
\hline elektricien, eigenaar elektrotechnisch bedrijf & $\boldsymbol{\Delta}$ & 57,0 & 61 & 56,5 & 45 & 51,9 & 52 \\
\hline maatschappelijk werker & & 56,8 & 62 & 52,6 & 52 & 56,0 & 43 \\
\hline technisch tekenaar & & 56,2 & 64 & 55,5 & 47 & 60,2 & 38 \\
\hline bedrijfsleider van een café-restaurant & & 56,0 & 65 & 54,7 & 48 & 54,1 & 46 \\
\hline verzekeringsagent & $\boldsymbol{\Delta}$ & 54,7 & 68 & 51,8 & 53 & 45,4 & 63 \\
\hline leraar basisonderwijs & $\nabla$ & 54,5 & 69 & 58,6 & 42 & 59,0 & 42 \\
\hline boekhouder & $\Delta$ & 54,5 & 70 & 53,7 & 49 & 53,3 & 47 \\
\hline secretaresse & & 54,2 & 71 & 44,5 & 63 & 46,2 & 61 \\
\hline begrafenisondernemer & $\boldsymbol{\Delta}$ & 53,7 & 72 & 51,4 & 54 & 41,8 & 68 \\
\hline bedrijfsleider in een supermarkt & & 53,5 & 73 & 49,3 & 58 & 50,9 & 56 \\
\hline geluidstechnicus bij een omroeporganisatie & & 53,1 & 74 & 44,5 & 64 & 53,3 & 49 \\
\hline
\end{tabular}




\begin{tabular}{|c|c|c|c|c|c|c|c|}
\hline Beroep 2016 & Trend & $\begin{array}{r}\text { Schaal } \\
2016\end{array}$ & $\begin{array}{r}\text { Positie } \\
2016\end{array}$ & $\begin{array}{r}\text { Schaal } \\
2006\end{array}$ & $\begin{array}{r}\text { Positie } \\
2006\end{array}$ & $\begin{array}{r}\text { Schaal } \\
1982\end{array}$ & $\begin{array}{r}\text { Positie } \\
1982\end{array}$ \\
\hline kok & & 52,6 & 75 & 38,4 & 74 & 39,9 & 69 \\
\hline $\begin{array}{l}\text { winkelier, zelfstandig in aardappelen, groente } \\
\text { \& fruit }\end{array}$ & $\boldsymbol{\Delta}$ & 52,3 & 76 & 50,8 & 55 & 45,4 & 62 \\
\hline slager, eigenaar slagerij & & 51,4 & 77 & 53,0 & 51 & 49,1 & 57 \\
\hline bibliothecaris, openbare bibliotheek & & 50,9 & 79 & 50,3 & 56 & 51,8 & 53 \\
\hline $\begin{array}{l}\text { agrariër landltuinbouw, alleen leidinggevend, } \\
\text { groot bedrijf }\end{array}$ & & 50,6 & 81 & 60,9 & 38 & 53,4 & 48 \\
\hline ploegbaas in metaalconstructiebedrijf & $\Delta$ & 48,4 & 82 & 47,8 & 59 & 47,5 & 59 \\
\hline kapper, eigenaar kapsalon & & 47,8 & 83 & 47,6 & 60 & 42,3 & 66 \\
\hline tandarts-assistente & & 47,6 & 84 & 38,6 & 72 & 41,9 & 67 \\
\hline boswachter & & 47,3 & 85 & 34,8 & 79 & 39,0 & 72 \\
\hline eigenaar van kiosk, met postafhaalpunt & & 46,1 & 88 & 43,6 & 66 & 47,6 & 58 \\
\hline $\begin{array}{l}\text { agrariër land/tuinbouw, zonder personeel, } \\
\text { klein bedrijf }\end{array}$ & $\boldsymbol{\Delta}$ & 45,3 & 90 & 41,5 & 68 & 39,1 & 70 \\
\hline eigenaar copyshop & $\Delta$ & 45,2 & 91 & 40,6 & 69 & 36,3 & 78 \\
\hline verzorgende in dagopvang voor ouderen & & 45,0 & 92 & 37,6 & 75 & 34,4 & 84 \\
\hline gemeenteambtenaar op afdeling bevolking & $\boldsymbol{\nabla}$ & 45,0 & 93 & 49,5 & 57 & 54,4 & 45 \\
\hline fijnmetaalbewerker & & 45,0 & 95 & 34,0 & 82 & 35,2 & 81 \\
\hline melkveehouder & $\Delta$ & 43,6 & 96 & 39,2 & 71 & 34,8 & 82 \\
\hline gevangenenbewaarder & $\Delta$ & 41,9 & 98 & 34,0 & 81 & 30,8 & 87 \\
\hline caféhouder & $\Delta$ & 41,6 & 100 & 40,1 & 70 & 35,5 & 80 \\
\hline $\begin{array}{l}\text { machinebankwerker (onderhouden, bouwen, } \\
\text { monteren en repareren van machines) }\end{array}$ & & 40,2 & 102 & 26,3 & 92 & 28,4 & 89 \\
\hline hovenier & & 40,2 & 103 & 33,1 & 84 & 37,8 & 76 \\
\hline treinconducteur & & 39,8 & 104 & 32,2 & 85 & 37,8 & 74 \\
\hline kunstschilder & & 38,5 & 105 & 36,8 & 76 & 45,3 & 64 \\
\hline receptionist(e)/telefonist(e) & & 36,3 & 106 & 32,2 & 86 & 34,6 & 83 \\
\hline bloemist & & 36,0 & 107 & 34,8 & 78 & 39,0 & 73 \\
\hline meubelstoffeerder & & 35,5 & 109 & 28,6 & 88 & 30,9 & 86 \\
\hline lasser & $\Delta$ & 34,4 & 111 & 24,0 & 95 & 22,4 & 101 \\
\hline metselaar & & 34,0 & 112 & 26,8 & 89 & 27,0 & 93 \\
\hline huisschilder & & 33,5 & 113 & 25,1 & 94 & 25,4 & 94 \\
\hline varkenshouder & & 31,4 & 117 & 33,2 & 83 & 28,2 & 90 \\
\hline postbode & & 31,1 & 118 & 26,7 & 90 & 27,0 & 92 \\
\hline vrachtwagenchauffeur & $\boldsymbol{\Delta}$ & 30,9 & 119 & 26,4 & 91 & 23,2 & 99 \\
\hline bulldozermachinist & & 30,2 & 120 & 22,8 & 97 & 24,6 & 95 \\
\hline kelner/serveerster & & 28,4 & 122 & 22,0 & 99 & 23,6 & 98 \\
\hline winkelbediende & & 25,5 & 125 & 18,1 & 100 & 22,2 & 102 \\
\hline marktkoopman/vrouw & & 25,4 & 126 & 26,0 & 93 & 22,6 & 100 \\
\hline arbeider, land- of tuinbouw & & 25,2 & 127 & 17,6 & 101 & 24,6 & 96 \\
\hline magazijnbediende & & 24,9 & 128 & 16,7 & 102 & 21,1 & 103 \\
\hline glazenwasser & & 18,8 & 130 & 14,1 & 106 & 16,7 & 109 \\
\hline schoorsteenveger & & 18,7 & 131 & 12,7 & 108 & 16,5 & 110 \\
\hline kamermeisje/jongen in een hotel & & 15,3 & 133 & 12,4 & 109 & 17,3 & 108 \\
\hline medewerker strijkservice & & 14,8 & 135 & 9,6 & 112 & 15,3 & 111 \\
\hline
\end{tabular}




\begin{tabular}{|l|r|r|r|r|r|r|r|}
\hline Beroep 2016 & Trend & Schaal & Positie & Schaal & Positie & Schaal & Positie \\
\hline medewerker aan de lopende band in fabriek & & 2016 & 2016 & 2006 & 2006 & 1982 & 1982 \\
\hline vuilnisophaler & 12,3 & 137 & 9,6 & 111 & 18,4 & 105 \\
\hline
\end{tabular}

Deze sterke gelijkenis in de rangordening in de afgelopen 35 jaar betekent uiteraard niet dat er helemaal geen afwijkingen zijn. We zien bijvoorbeeld dat de relatieve schaalscores voor drie lerarenberoepen in de genoemde periode dalen. Die daling is voor leraren in het eerstegraadsgebied in het voortgezet onderwijs het sterkst en het meest duidelijk, maar ook voor de leraren in het tweedegraadsgebied en de leraren in het basisonderwijs gaat het om een neerwaartse trend. We zien overigens slechts bij een gering aantal andere beroepen dat de trend dat de relatieve schaalscore bij iedere meting lager uitkomt dan bij de vorige: naast de lerarenberoepen geldt dat alleen voor journalisten, pastoors/dominees, gemeenteambtenaren op de afdeling bevolking en - in lichte mate - de tandartsen. Voor veel meer beroepen ( 26 in totaal) is een continue stijging van het maatschappelijk aanzien waarneembaar. Verpleegkundigen en profvoetballers zijn hiervan de meest duidelijke voorbeelden. Uit het voorgaande blijkt dat het niet zo is dat er sprake is van een algehele daling van beroepen op hbo- en/of wo-niveau waar het beroep van leraar binnen past.

In onderstaande grafiek (Figuur 5.1) hebben we de schaalscores van 2016 (verticaal) en 2006 (horizontaal) uiteengezet. Het feit dat de beroepen als een relatief smalle puntenwolk rond één lijn liggen wijst op de sterke correlatie tussen beide jaren. Beroepen boven de lijn scoren in 2016 hoger dan in 2006 en zijn dus gestegen op de ladder van maatschappelijk aanzien. Beroepen onder de lijn scoorden in 2006 hoger dan in 2016 en deze zijn dus in prestige gedaald. De lerarenberoepen bevinden zich duidelijk aan de kant van de beroepen die in aanzien zijn gedaald. Bij wijze van voorbeeld hebben we ook een aantal beroepen opgenomen die zijn gestegen in aanzien. 
FIGUUR 5.1 Relatieve schaalscores 2016 (verticaal) en 2006 (horizontaal)

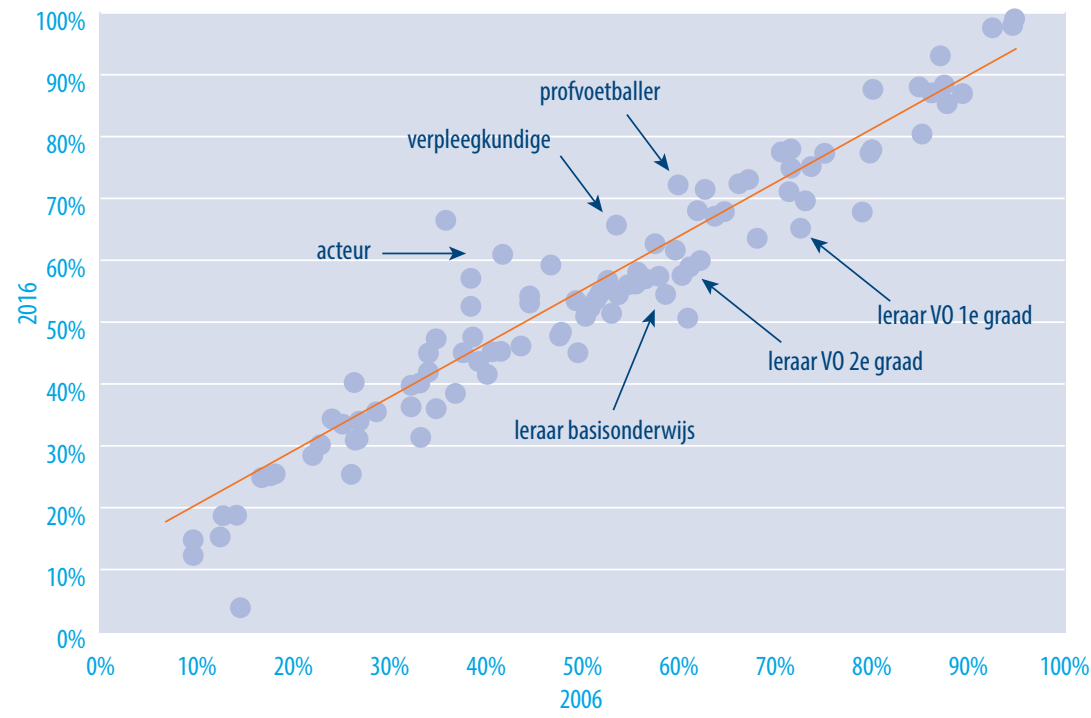

\subsection{Reflectie}

In dit hoofdstuk hebben we ons gericht op het maatschappelijk aanzien van het lerarenberoep. We hebben er in vergelijkende termen over gesproken, vergelijkend met andere beroepen en vergelijkend over de tijd. Het onderzoek richt zich op de Lerarenagenda en vanuit dat oogpunt is deze meting bedoeld als een nulmeting. De vergelijking in de tijd wordt op een later moment vooral relevant wanneer de opbrengsten van de Lerarenagenda bepaald gaan worden.

Een eerste belangrijke conclusie is dat maatschappelijk aanzien van de leraar verschilt naar het soort leraar. Leraren in het eerstegraadsgebied van het voortgezet hebben het hoogste maatschappelijk aanzien, gevolgd door leraren in het tweedegraadsgebied in het voortgezet onderwijs, leraren in het mbo en leraren in het basisonderwijs. In deze volgorde is de ordening te herkennen door het benodigde opleidingsniveau in combinatie met salaris en doordat algemeen vormende vakken hoger worden gewaardeerd dan beroepsgerichte.

De vier genoemde lerarenberoepen nemen een range in van ongeveer 10 procent op de totale ladder van maatschappelijk aanzien voor beroepen in Nederland: grofweg van 55 tot 65 op een schaal van o tot 100. Dat betekent dat lerarenberoepen redelijk wat maatschappelijk aanzien wordt toegedicht maar dat deze beroepen zeker niet tot de top behoren. Vergeleken met de meer klassieke professies als professionals in de gezondheidszorg of juristen (notariaat / advocatuur) staat de leraar in heel wat minder aanzien. De leraar basisonderwijs laat zich eerder vergelijken met een secretaresse, boekhouder of verzekeringsagent en een leraar in de bovenbouw van havo/vwo met een verloskundige of dominee. 
Ontwikkelingen in imago van beroepen zijn vermoedelijk processen die lange tijd bestrijken. Veranderingen daarin gaan langzaam. Dat laten de correlaties tussen de beroepenladders in de loop van 35 jaar ook zien. Op basis van de beroepenladder en de vergelijking met de eerdere metingen zijn we toch minder positief over het stabiele imago van het lerarenberoep dan eerdere auteurs dat waren (Groenewegen et al., 2007). Waar zij constateren dat het imago van het lerarenberoep slechts weinig verandert in de loop van de tijd, geven onze resultaten aan dat er in ieder geval voor de eerstegraads leraren in het voortgezet onderwijs sprake is van een duidelijke meerjarige neerwaartse trend in het imago. Het prestige van een leraar op het gymnasium was in 1982 nog min of meer vergelijkbaar was met dat van een kolonel in het leger. In 2016 ligt het beroep van eerstegraads leraar ongeveer op het niveau van een sergeant in het leger. Voor de leraar in het tweedegraadsgebied en in het basisonderwijs geldt eveneens dat er sprake is van een voortgaande daling over de jaren 1982, 2006 en 2016, alleen is deze minder sterk. 



\section{THEMA'S UIT DE LERARENAGENDA}

\subsection{Inleiding}

De Lerarenagenda is bedoeld als aanzet voor een antwoord op zorgen over de kwaliteit van het leraarschap, over het onderwijs en over het onderwijsbeleid. Het betreft de grootste gemene deler aan uitdagingen en verbeterpunten op het terrein van het leraarschap. Die onderwerpen zijn in zeven thema's verwerkt (zie www.delerarenagenda. $\mathrm{nl} /$ ). Eén van die thema's is het imago van het beroep vanuit het perspectief dat er nu sprake is van een te zwakke beroepsorganisatie en een cultuur in het veld die te weinig is gericht op professionele ontwikkeling.

In het onderzoek is daarom aan de leraren een aantal vragen gesteld die raken aan zaken als de professionele ontwikkeling en de organisatiegraad. Drie elementen staan daarin centraal: het lerarenregister, de activiteiten die leraren ondernemen in het kader van hun professionele ontwikkeling en het lid zijn van een beroepsorganisatie.

\subsection{Lerarenregister}

Het lerarenregister is in 2012 gestart als een vrijwillig register. Leraren kunnen zich registreren en in het register hun professionaliseringsactiviteiten bijhouden. Het oorspronkelijke idee was dat leraren eigenlijk net als andere professies (artsen, notarissen en advocaten) de kwaliteit van hun eigen beroep zouden moeten bewaken. Een register zou daarbij bijdragen aan extra status voor de beroepsgroep. In de loop van de tijd is meer de nadruk komen te liggen op het nut van het register als een manier om te blijven werken aan professionele ontwikkeling. De beroepsgroep is via de Onderwijscoöperatie betrokken bij de ontwikkeling van het register ${ }^{26}$. Het idee is dat ingeschreven leraren met het keurmerk'Registerleraar' laten zien dat ze bevoegd en bekwaam zijn én daaraan blijven werken. Dat moet bijdragen aan het vertrouwen van leerlingen, ouders, collega's en schoolleiding in hun professionaliteit.

Tussen een kwart en een derde van de leraren geeft op het moment van de enquête (april 2016) aan zich ingeschreven te hebben in het lerarenregister. In Figuur 6.1 zien we

26 De Onderwijscoöperatie is een initiatief van de grootste onderwijsvakorganisaties in Nederland: de Algemene Onderwijsbond, Beter Onderwijs Nederland, CNV Onderwijs, de Federatie van Onderwijsvakorganisaties en het Platform VVVO. 
dat het primair onderwijs daarbij een beetje achterblijft bij de andere sectoren. Bijna de helft van de leraren weet van het bestaan van het register af maar heeft zich desondanks (nog) niet ingeschreven. Eén vijfde tot een kwart van de leraren weet niet wat het lerarenregister is of weet niet of ze zijn ingeschreven, wat waarschijnlijk betekent dat ze weinig zicht hebben op wat het register inhoudt.

We zien dat jongere leraren zich vaker in het register hebben ingeschreven dan oudere. Van de leeftijdsgroep leraren tot en met 25 jaar heeft 40 procent zich ingeschreven, van de 55-plussers een kwart.

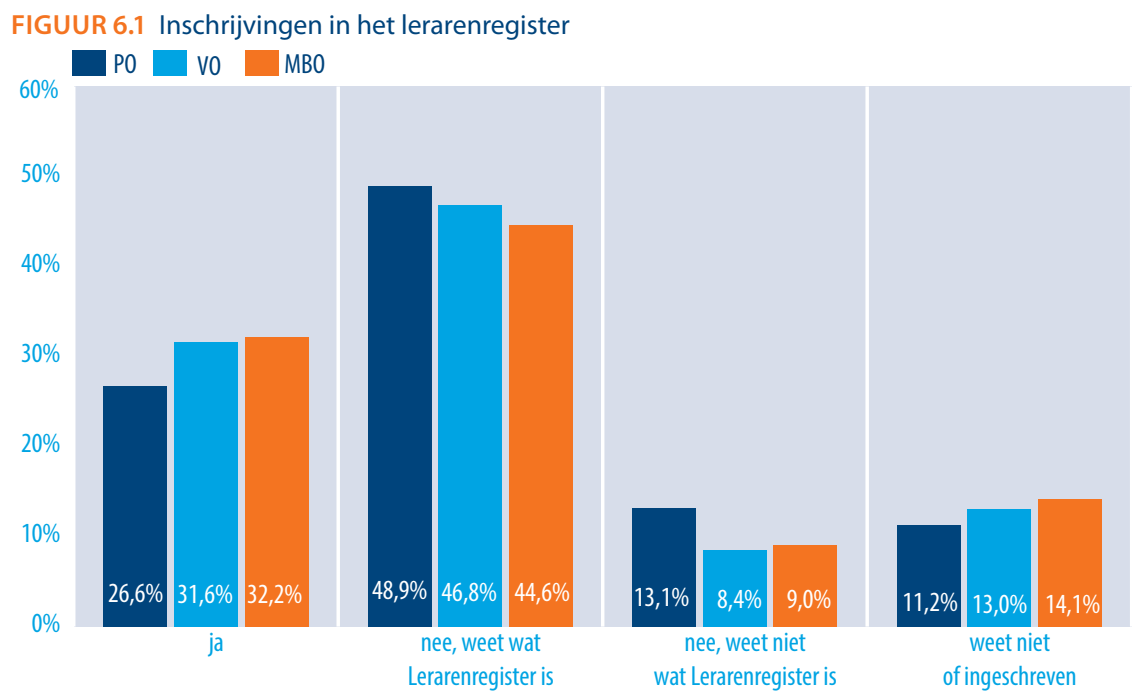

Ongeveer 60 procent van de ingeschreven leraren (één op de drie à vier) maakt daadwerkelijk gebruik van het register door de professionaliseringsactiviteiten erin bij te houden (bijvoorbeeld opleidingen, cursussen, studiedagen, conferenties). Van het totaal van de leraren gebruikt ongeveer één op de zes het lerarenregister actief.

TABEL 6.1 Redenen waarom leraren niet zijn ingeschreven in het lerarenregister

\begin{tabular}{|l|r|r|r|r|}
\hline Het is mij onduidelijk wat de functie van het lerarenregister is & P0 & V0 & MBO & Totaal \\
\hline Het is er nog niet van gekomen & $21 \%$ & $15 \%$ & $19 \%$ & $18 \%$ \\
\hline Ik zie het nut er niet van in & $35 \%$ & $29 \%$ & $33 \%$ & $32 \%$ \\
\hline Andere reden & $33 \%$ & $40 \%$ & $29 \%$ & $34 \%$ \\
\hline
\end{tabular}

Van de leraren die zich (nog) niet hebben ingeschreven, geeft ongeveer een derde aan dat het er nog niet van gekomen is (Tabel 6.1). Dat klinkt als een reservoir van leraren dat op termijn relatief eenvoudig aan de reeds ingeschreven groep kan worden toegevoegd. Verder ziet ruim de helft van de leraren die zich niet heeft ingeschreven het nut 
van het lerarenregister niet, of snapt de functie van het lerarenregister niet (of is niet overtuigd van nut/functie).

Bij de 'andere reden' die leraren opgeven komen zowel praktische als meer principiële motieven naar voren. Het (bijna) bereiken van de pensioengerechtigde leeftijd is daarbij één van de meest gehanteerde praktische varianten. Verder maken diverse leraren zich zorgen over hun privacy, ervaren leraren het register als bureaucratische rompslomp en weigert een deel op principiële gronden zich in te schrijven omdat het register niets bijdraagt aan de kwaliteit of omdat de eisen voor de te registreren ontwikkelactiviteiten veel te laag zouden zijn. In die visie dekt het register de problemen eerder toe dan dat het ze oplost en zijn met name aanbieders van laagdrempelige professionaliseringsactiviteiten erbij gebaat. Het wetgevingstraject voor het lerarenregister is inmiddels conform de plannen afgerond, waardoor het vrijwillige lerarenregister overgaat in een nieuw register. Vanaf het schooljaar 2018/2019 zullen alle bevoegde leraren geregistreerd zijn in het nieuwe lerarenregister en hun professionaliserings-activiteiten bijhouden in het register.

\subsection{Professionaliseringsactiviteiten}

Los van het lerarenregister ondernemen leraren nu uiteraard ook al professionaliseringsactiviteiten. In het onderzoek is gevraagd welke activiteiten leraren de afgelopen 12 maanden hebben ondernomen (het ging om de periode van ongeveer april 2015 tot april 2016). Daarbij zijn verschillende soorten professionaliseringsactiviteiten onderscheiden.

- Cursussen, trainingen, workshops

- Begeleiding, coaching van collega's

- Onderwijsconferenties of-seminars

- Netwerk gericht op professionele ontwikkeling

- Onderzoek naar onderwijsgerelateerd thema

- Bezoek aan bedrijven/organisaties

- Bezoek aan andere scholen

- Opleiding met kwalificatieprogramma

De meeste van deze activiteiten waaraan leraren hebben deelgenomen, blijken minder dan één week te duren. Alleen bij de opleidingen met een kwalificatieprogramma duurt een substantieel deel (42\%) langer dan één maand.

In Figuur 6.2 laten we zien hoe vaak deze activiteiten door leraren worden gebruikt of toegepast in het kader van hun professionele ontwikkeling. Cursussen, trainingen en workshops zijn de meest genoemde activiteiten (door ongeveer 95\% van de leraren). Het minst genoemd worden opleidingen voorzien van een kwalificatieprogramma (door ongeveer een kwart van de leraren). Er zijn weinig verschillen naar schooltype. Wel valt op dat in vergelijking met beide andere sectoren in het mbo een bezoek aan bedrijven 
of organisaties vaak genoemd wordt als professionaliseringsactiviteit. Vermoedelijk speelt de beroepspraktijkvorming van het mbo hierin een belangrijke rol.

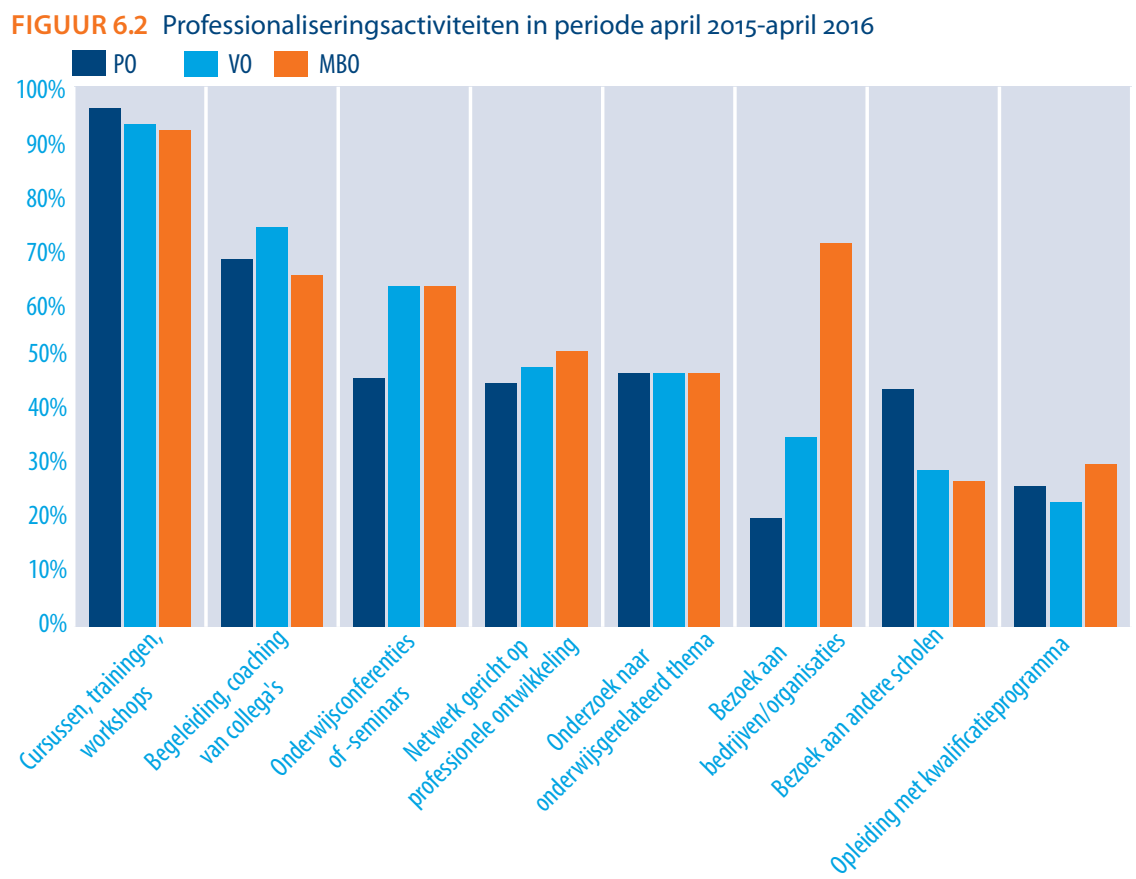

Er is een zwak, maar zeer consistent verband in de participatie aan de verschillende professionaliseringsactiviteiten. Dus, als een leraar aan één professionaliseringsactiviteit deelneemt, is de kans iets groter dat hij of zij ook nog aan één of meerdere andere activiteiten deelneemt. Het gaat om zwakke onderlinge positieve correlaties (ruwweg tussen de 0,10 en 0,20 ) die allemaal statistisch significant zijn.

We zien nauwelijks relaties tussen de inschrijving in het lerarenregister en de professionaliseringsactiviteiten die leraren opgeven. Over het algemeen geven ingeschreven leraren niet meer activiteiten op dan niet ingeschreven leraren. Wel zien we dat de opleidingen met een kwalificatieprogramma vaker door leraren met een registerinschrijving gevolgd worden (37\%) dan door leraren zonder inschrijving (24\%). Ook blijken registerleraren vaker deel uit te maken van een netwerk gericht op de professionele ontwikkeling (61\%) dan leraren zonder inschrijving (46\%). Het gaat hierbij uitdrukkelijk om een samenhang: het is niet duidelijk of er sprake is van een eventueel causaal verband, dus dat inschrijving in het register zou leiden tot deelname aan netwerken en aan opleidingen met kwalificatieprogramma's (of juist andersom).

We zien wel duidelijke patronen in de deelname aan het soort professionaliseringsactiviteiten en wat betreft de leeftijd van leraren (Figuur 6.3). Naarmate leraren ouder zijn 
nemen ze minder vaak deel aan formele scholing met een kwalificatieprogramma, maar ook aan onderwijsconferenties of -seminars en netwerken gericht op professionele ontwikkeling. We weten niet of het hier gaat om een carrière-effect of een cohort-effect, dus of leraren naarmate ze ouder worden minder deelnemen aan dergelijke activiteiten (carrière-effect) of dat er in de loop van de tijd een andere generatie leraren aantreedt die meer aan dergelijke activiteiten deelneemt. De oudere leraren doen tot hun $55 \mathrm{e}$ jaar wel meer aan begeleiding en coaching van andere leraren in het kader van de professionele ontwikkeling.

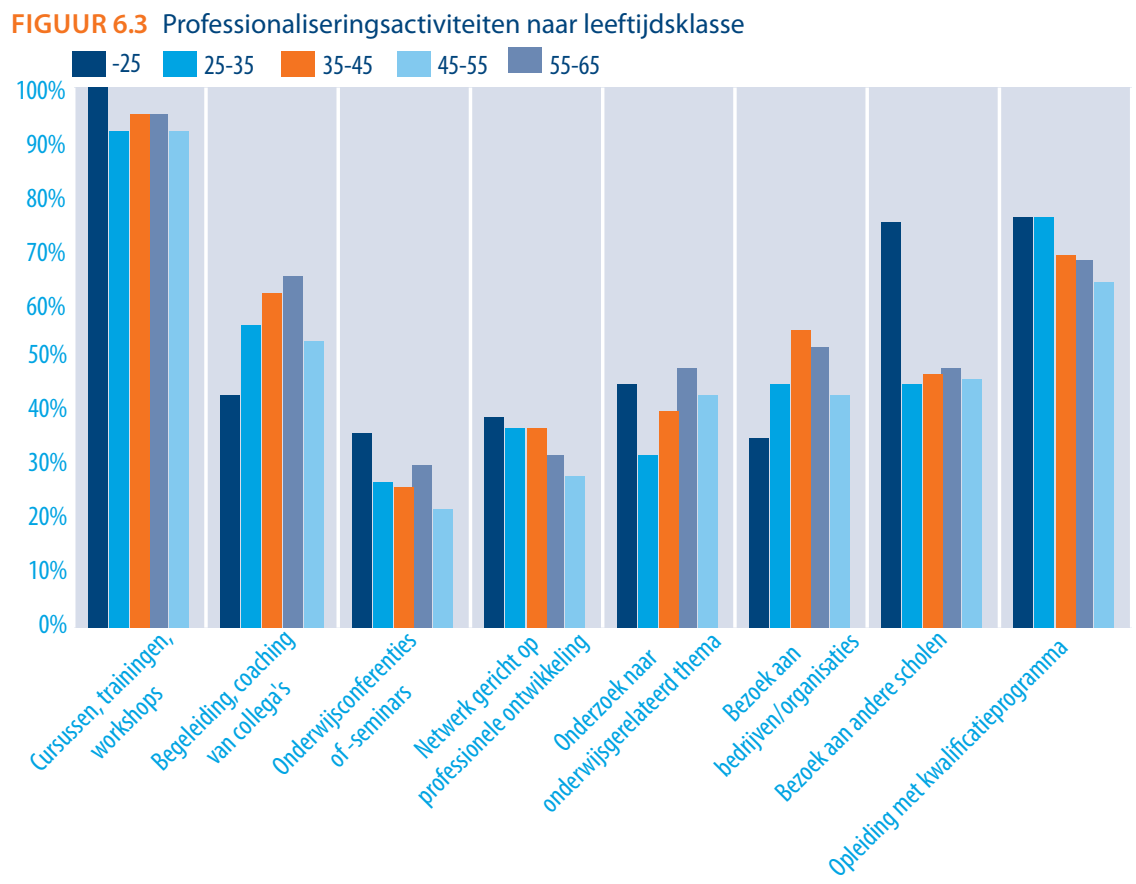

Bij meer dan 90 procent van de activiteiten draagt de school of de werkgever (een deel) van de eventuele kosten voor de professionalisering. Bij een kwart dragen leraren ook een deel van de kosten. De Lerarenbeurs wordt bij 7 procent gebruikt om professionaliseringsactiviteiten (deels) mee te financieren. Dat ligt specifiek bij opleidingen met een kwalificatieprogramma een stuk hoger: daarvoor wordt bij een kwart ook de Lerarenbeurs gebruikt.

\subsection{Netwerken}

Naast het register en professionaliseringsactiviteiten draagt ook het participeren in netwerken of het aangesloten zijn bij beroepsorganisaties bij aan een sterkere (profilering van de) beroepsgroep. We onderscheiden in dit onderzoek vijf soorten netwerken of groepen waarin leraren kunnen participeren. 
1. Algemene beroepsorganisaties van leraren, bijvoorbeeld Beter Onderwijs Nederland, Leraren met Lef, FvoV, Platform VVVO, Vereniging van Meesterschappers;

2. Specifieke beroepsorganisaties voor leraren, bijvoorbeeld Beroepsvereniging van docenten mbo, Landelijke Beroepsvereniging voor Remedial Teachers, Stichting Platforms vmbo;

3. Onderwijsbonden, bijvoorbeeld CNVO, Aob;

4. (Lokale) netwerken van leraren;

5. Online netwerk van leraren, bijvoorbeeld via Linkedln of Facebook.

In Figuur 6.4 geven we een overzicht van de deelname aan dergelijke netwerken naar sector.

FIGUUR 6.4 Participatie naar onderwijssector

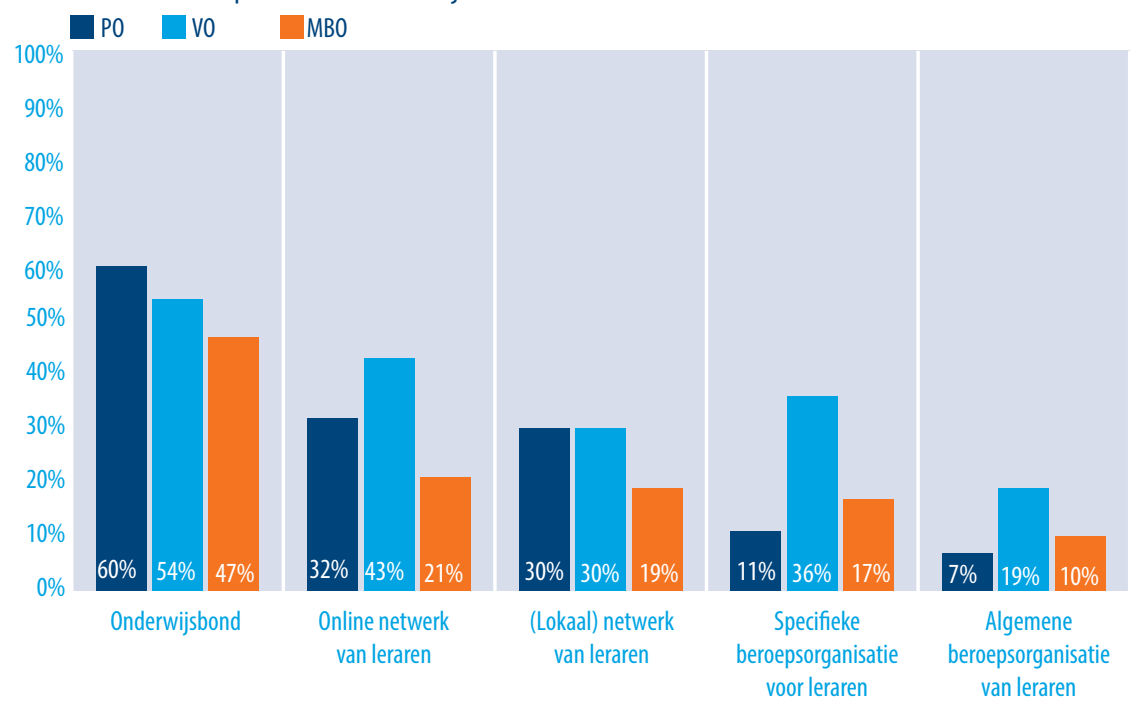

Leraren blijken vooral aangesloten bij één (of meer) van de vakbonden. Daarbij staan rechtspositionele aspecten meer dan de inhoud van het beroep centraal. Het valt op dat bij de andere vormen van participatie leraren in het voorgezet onderwijs wat actiever lijken dan leraren in de beide andere sectoren. In het po en mbo is de deelname aan specifieke of algemene beroepsorganisaties kleiner. Dat heeft ongetwijfeld ook met een kleiner aanbod van dergelijke organisaties te maken in die sectoren.

Voor participatie in netwerken geldt iets soortgelijks als voor de professionaliseringsactiviteiten: er is een zwak verband tussen de afzonderlijke participatievormen. Het gaat hier om iets sterkere verbanden (correlaties tussen de 0,15 en 0,30 ) die nagenoeg allemaal statistisch significant en positief zijn. 
Verder vertoont het lidmaatschap van een vakbond duidelijk een verband met leeftijd. De organisatiegraad onder oudere leraren is hoger dan onder de jongere leraren (zie Figuur 6.5). De overige netwerken of beroepsverenigingen laten een minder duidelijk verloop met leeftijd zien. Deelname aan netwerken (lokaal of digitaal) ligt vooral hoog onder de leraren in de leeftijdsgroep van 35 tot 45 jaar. Het lidmaatschap van algemene of specifieke beroepsverenigingen ligt relatief hoog onder de jongste leeftijdsgroep van leraren tot 25 jaar.

\section{FIGUUR 6.5 Participatie naar leeftijd \\ Bent u lid of aangesloten bij: Algemene beroepsorganisatie van leraren Bent u lid of aangesloten bij: Specifieke beroepsorganisatie voor leraren \\ Bent u lid of aangesloten bij: Onderwijsbond \\ Bent u lid of aangesloten bij: (Lokaal) netwerk van leraren \\ Bent u lid of aangesloten bij: Online netwerk van leraren}

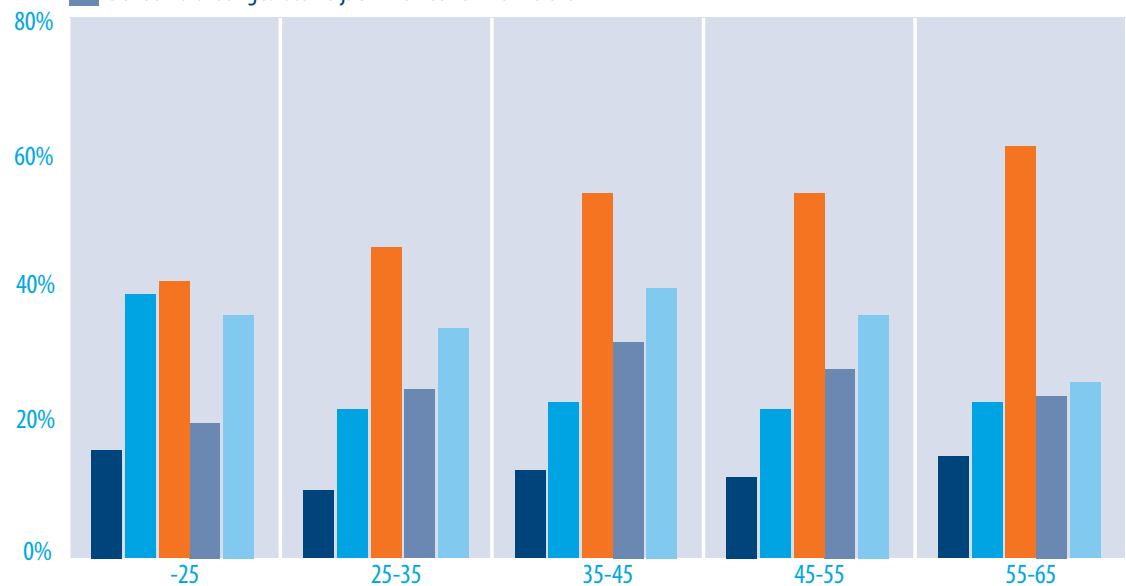

\subsection{Relaties met imago}

We hebben onderzocht of leraren die meer met hun professionele ontwikkeling bezig zijn, een andere kijk hebben op het oordeel van de buitenwereld over hun beroep. Onze verwachting daarbij was dat zelfverzekerde beroepsuitoefenaars die op verschillende manieren aan hun professionele ontwikkeling werken, van mening zijn dat de bevolking en ouders in het bijzonder, positiever tegen het lerarenberoep aankijken.

Dat wordt niet bevestigd door de uitkomsten van het onderzoek. Leraren die aan diverse professionaliseringsactiviteiten deelnemen schatten het oordeel van de bevolking of ouders niet systematisch anders in dan leraren die niet deelnemen. Alleen deelnemers aan opleidingen met kwalificatieprogramma blijken licht oververtegenwoordigd in de groep die denkt dat de bevolking heel weinig waardering heeft voor leraren en is ondervertegenwoordigd in de groep die van mening is dat de bevolking juist leraren heel positief waardeert. 
Of leraren participeren in netwerken of lid zijn van beroepsverenigingen of vakbonden hangt niet samen met de inschatting van het oordeel van de bevolking over leraarschap. Voor de inschrijving in het lerarenregister zien we juist een licht (maar statistisch significant) negatief verband: registerleraren denken dat de bevolking minder waardering voor de leraar heeft dan de leraren die (nog) niet in het register zijn ingeschreven (Figuur 6.6).

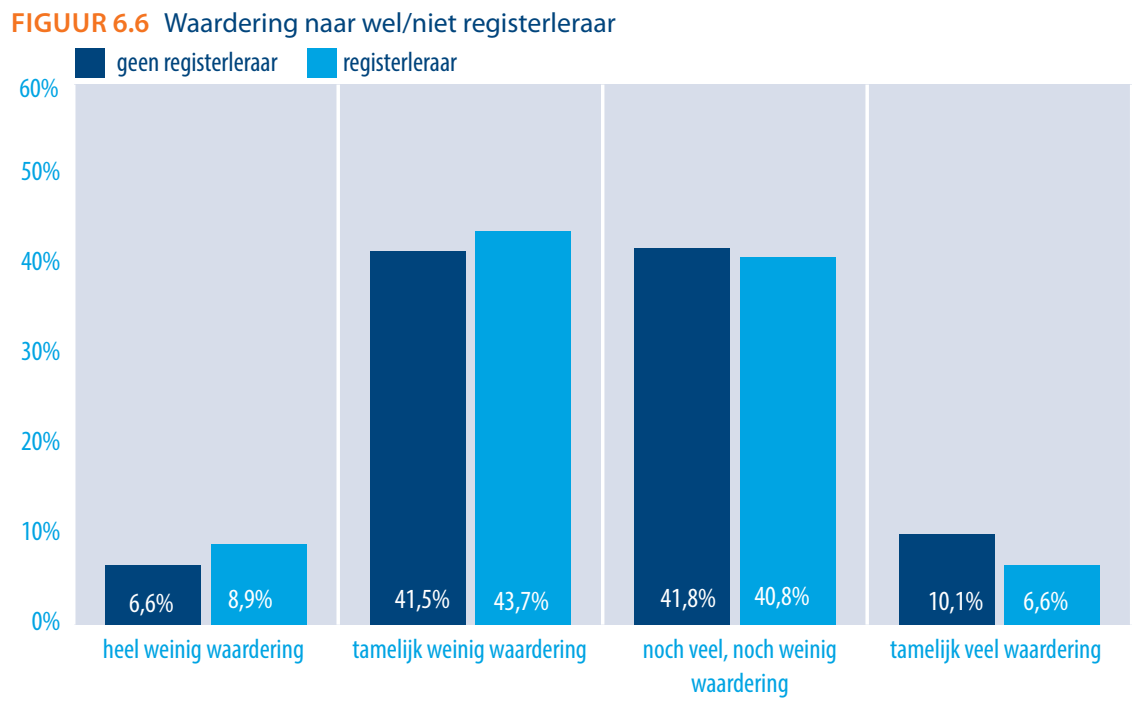

Chi $^{2}$ toets: $p<0,96$

\subsection{Reflectie}

De Lerarenagenda heeft als doel de kwaliteit van de leraar en het onderwijs op een hoger plan te tillen. Professionalisering en een sterke beroepsgroep zijn daarin onderwerpen die regelmatig voorbij komen. Eén op de drie à vier leraren had zich op het moment van enquêtering in april 2016 in het vrijwillige lerarenregister ingeschreven. Ongeveer 60 procent daarvan gebruikt dat register ook daadwerkelijk en houdt zijn of haar professionaliseringsactiviteiten erin bij. De (nog) niet-gebruikers hebben twijfels over nut van het register. Een beperkt deel heeft meer principiële bezwaren tegen inschrijving. Het is nog niet duidelijk hoe deze groep zal reageren op de verplichte registratie vanaf het schooljaar 2017/2018.

Professionaliseringsactiviteiten van leraren spitsen zich toe op (korte) trainingen/workshops e.d. Daaraan heeft het overgrote deel van de leraren (binnen een tijdsbestek van één jaar) deelgenomen. Daarnaast heeft tussen de 20 en 30 procent van de leraren in het afgelopen jaar deelgenomen aan een vorm van scholing met een kwalificatieprogramma. We zien dat met name deze laatste vorm vooral voor en door de jongere leraren en minder voor de oudere leraar wordt ingezet. 
Leraren blijken wat betreft hun netwerkvorming zich vooral aan te sluiten bij één (of meer) van de vakbonden. Bij de andere vormen van participatie in netwerken zijn leraren in het voorgezet onderwijs wat actiever dan leraren in de andere beide sectoren. In po en mbo is de deelname aan specifieke of algemene beroepsorganisaties kleiner.

Leraren die op verschillende manieren aan hun professionele ontwikkeling werken blijken niet vaker van mening te zijn dat de bevolking en ouders in het bijzonder, positiever tegen het lerarenberoep aankijkt. Diverse elementen uit de Lerarenagenda (inschrijving in het lerarenregister, participatie in netwerken, deelname aan professionaliseringsactiviteiten) hangen niet of nauwelijks samen met hoe leraren de waardering van hun beroep door de buitenwereld inschatten. 



\section{CONCLUSIES}

In dit slothoofdstuk kijken we terug op de belangrijkste bevindingen uit voorgaande hoofdstukken en trekken op basis daarvan conclusies over 'de' status en 'het' imago van leraren anno nu, en de ontwikkeling hierin over de afgelopen jaren c.q. decennia. In lijn met de opbouw van de rapportage bespreken we eerst de status van het leraarschap, en vervolgens het imago. Waar we status vooral meten door 'harde' kwaliteits- en beroepsindicatoren over de beroepsgroep van leraren, gaat het bij imago voornamelijk over de maatschappelijke perceptie van het leraarschap en het aan het beroep toegeschreven prestige. Imago heeft derhalve meer betrekking op zogenaamde 'zachte' indicatoren. Afsluitend wordt in dit hoofdstuk aandacht besteed aan de professionalisering en de beroepsorganisatie van leraren, wat van belang is in het licht van de Lerarenagenda.

\subsection{Status van de leraar}

Status is een multidimensionaal en lastig te omvatten begrip: het valt dan ook moeilijk te meten in één enkel cijfer. In lijn met de literatuur onderscheiden we in dit rapport diverse objectieve indicatoren voor status: namelijk de opleiding, de sociale compositie en de arbeidsmarktpositie van leraren. Zoals aangegeven in het inleidende hoofdstuk 1 , kunnen deze indicatoren op verschillende manieren samenhangen met de beroepsstatus.

\subsubsection{Opleiding}

\section{Instroom lerarenopleidingen}

De instroom in de hbo-opleiding leraar vo is de afgelopen tien jaar ruwweg stabiel gebleven. Al jarenlang betreft de instroom van deze lerarenopleiding ongeveer 4 procent van de totale hbo-instroom. De instroom in de pabo is in de laatste jaren echter drastisch afgenomen, zowel absoluut (in aantallen) als relatief (als aandeel van de totale instroom). Waar de instroom in de pabo in 2006 nog 10 procent van de gehele hboinstroom vormde, is dit aandeel in 2015 afgenomen tot 4 procent. Het is moeilijk te zeggen in hoeverre deze afname te wijten is aan verminderde aantrekkelijkheid van de opleiding, of aan verhoogde kwaliteitseisen. Zo is er een sterke samenhang tussen de afgenomen instroom en de aangescherpte kwaliteitseisen binnen de pabo, met name per studiejaar 2015/2016. Tegelijkertijd is de instroom in de pabo al lange tijd dalende, hetgeen een indicatie van verminderde populariteit en een verlaagde status kan zijn. 
Wel kan verwacht worden dat de kwaliteitsaanscherping zoals deze in de laatste jaren wordt geïmplementeerd statusverhogend werkt.

Hoewel de toelatingseisen vooral per 2015/2016 zijn aangescherpt, is al langere tijd een toenemend niveau van de vooropleiding van instromers in de pabo zichtbaar. De afgelopen tien jaar is de instroom vanuit mbo afgenomen en de instroom vanuit havo/vwo toegenomen: dit wijst mogelijk op een statusverhogende ontwikkeling. De vooropleiding van studenten aan de lerarenopleiding voor het vo lijkt juist iets af te nemen: de relatieve instroom vanuit het mbo en de havo is sinds 2006 toegenomen.

\section{Diplomarendement lerarenopleidingen}

Het diplomarendement in het hbo is al meer dan tien jaar dalende (enige fluctuaties daargelaten), maar daalt vooral snel onder de lerarenopleidingen. Het feit dat het rendement onder lerarenopleidingen sneller afneemt is niet eenduidig te verklaren. Mogelijk is het niveau en de kwaliteit van de opleiding omhoog gegaan met meer uitval als gevolg, hetgeen in lijn zou zijn met de aangescherpte eisen op de pabo. Andere verklaringen, zoals een minder goede begeleiding van studenten, zijn echter ook denkbaar. Welke gevolgen het dalend diplomarendement heeft voor de status van de leraar is daardoor niet duidelijk.

\section{Opleidingsniveau beroepsgroep}

Naast indicatoren voor de lerarenopleiding, kunnen we ook kijken naar de opleiding van de gehele beroepsgroep van leraren. Het beroep leraar is vergeleken met veel andere beroepen (en het gemiddelde, landelijke opleidingsniveau) al tientallen jaren een zeer hoogopgeleid beroep, zo blijkt uit de indicator GON (gemiddeld opleidingsniveau in jaren). Uit de wetenschappelijke literatuur is bekend dat de status van hoogopgeleide beroepen groter is dan voor andere beroepen. In die zin zijn leraren relatief statusrijk te noemen. De langetermijntrend in GON laat echter zien dat het opleidingsniveau van Nederland als geheel vrijwel structureel toeneemt, terwijl deze voor de groepen leraren vrij stabiel of zelfs licht dalend is. Hoewel leraren gemiddeld genomen dus fors hoger opgeleid zijn dan werkzaam Nederland als geheel, is de relatieve voorsprong tanende. Anders gesteld: de 'exclusiviteit' van leraren als hoogopgeleide beroepsgroep - en daarmee de status - is in de loop der jaren afgenomen. Wel lijkt dit ook te gelden voor veel andere beroepen met een van oudsher een groot aandeel hoogopgeleiden.

\subsubsection{Sociale compositie}

\section{Geslacht}

In alle onderwijssectoren (po, vo, mbo) is al sinds 1999 sprake van een vrijwel lineaire toename in het aandeel vrouwelijke leraren. Wel verschillen de percentages vrouwen in de onderwijssectoren erg veel van elkaar. Van oudsher is het primair onderwijs (po) de sterkst 'gefeminiseerde' sector: in 2015 was bijna negen op de tien leraren vrouw (87\%). In het voortgezet onderwijs (vo) en het middelbaar beroepsonderwijs ( $\mathrm{mbo}$ ) is het aandeel mannen en vrouwen veel gelijkmatiger verdeeld: anno 2015 bestond de lerarenformatie 
in deze sectoren uit vrijwel evenveel mannen als vrouwen (53\%). Vergeleken met de gehele werkzame beroepsbevolking wijkt de verdeling naar geslacht in het onderwijs erg af. In 2014 maakten vrouwen namelijk 45 procent uit van de totale werkende beroepsbevolking, terwijl in het po het percentage bijna twee keer zo hoog lag. Dit zeer hoge en bovendien toenemende aandeel vrouwen werkt wellicht statusverlagend voor leraren in het po.

\section{Leeftijd}

Vergrijsde beroepen zijn voor jongeren mogelijk minder aantrekkelijk om in te gaan werken. Vanuit deze veronderstelling heeft de snelle vergrijzing in het onderwijs in de afgelopen tien jaar de status van het leraarschap waarschijnlijk geen goed gedaan. Hoewel er ook landelijk sprake is van een vergrijzende beroepsbevolking, gaat dat minder snel dan in de beroepsgroep van leraren. Bovendien ligt het aandeel 55-plussers in het onderwijs vele malen hoger dan onder de gehele werkzame beroepsbevolking. Onder leraren in het vo bijna twee keer, en in het mbo zelfs méér dan twee keer zo hoog. Wel lijkt het vergrijzingsproces in het onderwijs sinds 2013 te stagneren.

\section{Niet-westerse allochtonen}

De status van een beroep hangt mogelijk samen met het aandeel niet-westerse allochtonen, omdat zij relatief vaak een lager opleidingsniveau en een lager inkomen hebben dan autochtonen. In de onderwijssectoren vo en mbo is het aandeel niet-westerse allochtonen de afgelopen vijftien jaar groeiende, terwijl het in het po stabiel is gebleven. De percentages niet-westerse allochtonen zijn binnen het onderwijs echter veel lager dan in de gehele werkzame beroepsbevolking: in 2014 bijna twee keer zo laag. Of dit daadwerkelijk de status van het beroep leraren beïnvloedt, is moeilijk te zeggen. Het is immers evengoed denkbaar dat een beroep met een hoge etnische diversiteit juist aantrekkelijk is, en dat het onderwijs gebaat is bij een gemêleerde lerarenformatie.

\subsubsection{Arbeidsmarktpositie}

\section{Werkloosheid en dienstverband}

De werkloosheid onder pas afgestudeerden (anderhalf jaar na diplomering) van de hboopleiding leraar vo ligt al meer dan tien jaar onder het hbo-gemiddelde. Het gaat dan veelal om een lagere werkloosheid van enkele procenten. De werkloosheidsontwikkeling onder pas afgestudeerde pabo'ers is veel grilliger, soms enkele procenten onder het hbo-gemiddelde, soms enkele procenten erboven. In de meest recente meting (afgestudeerden uit 2014) ligt de werkloosheid onder zowel afgestudeerden van de pabo als de lerarenopleiding vo relatief laag op 4 procent. Ter vergelijking: onder alle hbo-afgestudeerden is de werkloosheid 6 procent. Een lage werkloosheid, en met name de structureel lagere werkloosheid voor de opleiding leraar vo, kan als positief voor de status van de beroepsgroep worden beschouwd.

Recent afgestudeerden van de opleiding leraar vo zijn niet alleen minder vaak werkloos dan het hbo-gemiddelde, ze hebben ook iets vaker een vast dienstverband. Dit is 
bovendien al meer dan tien jaar het geval en lijkt positief voor de status van de beroepsgroep. Afgestudeerden aan de pabo hebben juist veel minder vaak een vast dienstverband dan andere hbo'ers. Het percentage pabo'ers met een vast dienstverband is in de afgelopen tien jaar gekelderd. Wellicht heeft dit een negatieve invloed op de status van leerkrachten in het basisonderwijs.

\section{Aansluiting opleiding-arbeidsmarkt}

Afgestudeerden aan lerarenopleidingen met een baan hebben vrijwel altijd werk op hbo/wo-niveau. Al meer dan tien jaar hebben ongeveer negen op de tien afgestudeerde leraren werk op minimaal het eigen niveau. Dit is fors hoger (ongeveer 10 procent) dan onder de gehele populatie van hbo-afgestudeerden. Een lerarenopleiding lijkt daarom, in tegenstelling tot vele andere opleidingen, haast een garantie op een baan op niveau te geven. Bovendien hebben ongeveer acht op de tien (lerarenopleiding vo) tot negen op de tien (pabo) afgestudeerden van een lerarenopleiding die werkzaam zijn, een baan in het onderwijs. De match tussen de opleiding en de baan is hier dus erg goed. Dit hoge beroepsrendement is vermoedelijk goed voor de status van het leraarschap.

\section{Lonen}

Afgestudeerden aan de lerarenopleiding voor het vo verdienen relatief goed: het mediane uurloon van deze groep ligt al geruime tijd ongeveer 10 procent hoger dan onder de gehele populatie van hbo-afgestudeerden. Voor afgestudeerden aan de pabo is het beeld minder rooskleurig. Waar het mediane uurloon voor deze groep lange tijd hoger was dan voor het hbo-totaal, ligt het mediane uurloon na 2008 onder dat van het gehele hbo. Bovendien is de afstand tussen de lonen van de pabo'ers en de rest van het hbo, en met name tussen pabo'ers en vo-leraren steeds groter geworden. Waar de status van de vo-leraren op basis van de lonen dus hoog ingeschat kan worden, ligt deze voor pabo'ers relatief laag.

De lonen van de gehele beroepsgroep leraren (dus niet alleen de recent afgestudeerden) zijn de afgelopen decennia verhoudingsgewijs aanzienlijk gedaald. Waar het onderwijs in de jaren zestig en zeventig, vergeleken met andere sectoren in het publieke domein, relatief hoge lonen kende, zijn de beloningsverschillen daarna steeds kleiner geworden. De 'exclusiviteit' van het onderwijs in termen van beloning, en mogelijk daarmee de status is afgenomen. Wel liggen de uurlonen in het onderwijs nog altijd hoger dan in de zorg of de cultuursector.

Hoewel de lonen relatief gezien dus achteruit zijn gegaan, is er met name de laatste jaren wel sprake van absolute verbetering. In het kader van de functiemix-maatregel, waarmee scholen extra financiering ontvangen om leraren in functieschaal te bevorderen, is het aandeel leraren in hogere leraarschalen fors toegenomen. Zowel in het po als het vo is de verdeling over de verschillende functieschalen sterk veranderd ten gunste van de hogere schalen. Doordat het basisonderwijs voor leraren een lagere aanvangsschaal kent (schaal LA) dan in het vo, blijven de lonen in deze onderwijssector overigens wel achter ten opzichte van het vo. De absolute verbetering van de beloning 
kan de status van het beroep en daarmee de aantrekkelijkheid van het leraarschap wel hebben vergroot.

\subsection{Imago van het beroep}

Het imago van het beroep leraar is in dit rapport mede bestudeerd aan de hand van de absolute waardering voor het beroep van leraar en voor de verschillende aspecten van de beroepsuitoefening, en door de inschatting van het salaris door studenten van de lerarenopleidingen, leerlingen van mbo/havo/vwo en hun ouders. We hebben het imago van de leraar benaderd vanuit verschillende respondentgroepen, namelijk de leraren zelf, studenten aan de lerarenopleiding, ouders, leerlingen en de Nederlandse bevolking. Naast het vergelijken van de respondentgroepen, hebben we gekeken of de achtergrondkenmerken van de respondenten samenhangen met de waardering voor het leraarschap. De waardering in absolute zin wordt hier gemeten op een schaal van 1 tot 5 .

De inschatting van de waardering door de Nederlandse bevolking is met 3,2 voor po en vo en 3,1 voor mbo niet bepaald hoog. Ook denkt men dat de waardering door de Nederlandse bevolking over de afgelopen 20 jaar is gedaald. Vooral leraren verwachten dat de waardering laag is en vinden ook het meest van alle vijf de respondentgroepen dat de waardering is gedaald. Ouders en de Nederlandse bevolking zijn de meest positieve groepen als het gaat over waardering van het leraarschap. Hoe ouder de respondent (leraren en Nederlandse bevolking), hoe hoger de waardering wordt ingeschat. Ondanks de constatering dat de waardering over de afgelopen twintig jaar is afgenomen, geeft een vergelijking met de uitkomsten van de Onderwijsmeter 2008 (Plantinga et al., 2008) aanleiding te veronderstellen dat de waardering in de laatste 10 jaar weer is toegenomen.

Leraren zijn het meest positief over hun beroepsuitoefening van de respondentgroepen als het gaat om de omgang met leerlingen en ouders, vakkennis en kennis overbrengen aan leerlingen. Ten opzichte van de andere respondentgroepen scoren leraren significant positiever op alle uitspraken. In het po is men positiever over de beroepsuitoefening dan in het vo en mbo.

Qua achtergrondkenmerken zien we dat vooral de schoolkenmerken uitmaken, terwijl de leraarkenmerken er in mindere mate toe doen. Leraren op scholen in dorpen en kleinere steden zijn vaak positiever over de beroepsuitoefening dan leraren op scholen in middelgrote en grote steden. Daarnaast maakt het aandeel achterstandsleerlingen op een school een verschil in de beoordeling: leraren op po- en vo-scholen beoordelen de beroepsuitoefening negatiever naarmate er een hoger aandeel achterstandsleerlingen op de school zit. Een hoger aandeel achterstandsleerlingen (op deze schooltypen) leidt wellicht tot meer uitdagingen in de beroepsuitoefening door leraren. 
Het salaris van een leraar in het po wordt vrij goed wordt ingeschat. Als het gaat om leraren in het vo (algemeen vormende vakken en beroepsgerichte vakken), dan worden die 200 tot 450 euro te laag ingeschat. De hbo-beroepen waar de leraren mee worden vergeleken worden door alle respondentgroepen te hoog ingeschat, communicatieadviseurs zelfs meer dan 400 euro te hoog.

We concluderen dat het imago van het vak van leraar er niet goed voor staat. De inschatting van de absolute waardering door de Nederlandse bevolking is nauwelijks voldoende. Er zijn indicaties voor zowel een toename als een afname in de absolute waardering gedurende de laatste 10 of 20 jaar. Leraren zelf denken dat de Nederlandse bevolking nog minder waardering voor hen heeft dan feitelijk het geval is, terwijl de leraren wel aangeven goed te zijn in hun vak (positief over eigen beroepsuitoefening). Het imago wordt verder beïnvloed door een te lage inschatting van het salaris.

\subsection{De leraar op de beroepenladder}

Over het maatschappelijk aanzien van het lerarenberoep kan tevens in relatieve termen een uitspraak gedaan worden: door te vergelijken met andere beroepen en door te vergelijken in de tijd. Het maatschappelijk aanzien van de leraar verschilt naar het soort leraar. Eerstegraads leraren van het voortgezet onderwijs (i.e. bovenbouw havo/vwo) genieten het hoogste maatschappelijk aanzien, gevolgd door tweedegraads leraren in het voortgezet onderwijs (vmbo en onderbouw havo/vwo), waarna leraren in het mbo volgen en als laatste leraren in het basisonderwijs. Het benodigde opleidingsniveau voor de beroepsuitoefening in combinatie met het salaris lijken daarbij bepalend voor de verschillen in aanzien tussen lerarenberoepen. Daarnaast duiden deze uitkomsten erop dat lesgeven in algemeen vormende vakken hoger wordt gewaardeerd dan lesgeven in beroepsgerichte vakken.

Deze lerarenberoepen nemen een range in van ongeveer 10 procent op de totale ladder van maatschappelijk aanzien voor beroepen in Nederland: op een schaal van o tot 100 bevinden ze zich ergens in de range van 55 tot 65 . Lerarenberoepen worden daarmee redelijk wat maatschappelijk aanzien toegedicht, maar ze behoren zeker niet tot de top. Vergeleken met bijvoorbeeld professionals in de gezondheidszorg als chirurgen en artsen of juristen in het notariaat en de advocatuur geniet de leraar heel wat minder maatschappelijk aanzien. De leraar basisonderwijs laat zich qua aanzien vergelijken met een secretaresse, boekhouder of verzekeringsagent en een leraar in de bovenbouw van havo/vwo met een verloskundige of dominee.

Op basis van een vergelijking met de eerdere beroepenladders zijn we minder positief over het stabiele imago of prestige van het lerarenberoep dan eerdere studies (Groenewegen, 2007). Waar zij constateren dat het imago van het lerarenberoep nagenoeg niet verandert in de loop van de tijd, geven onze resultaten aan dat er in ieder geval voor de eerstegraads leraren in het voortgezet onderwijs sprake is van een duidelijke neerwaartse trend in het maatschappelijk aanzien. Het prestige van een leraar op 
het gymnasium was in 1982 nog min of meer vergelijkbaar met dat van een kolonel in de krijgsmacht. In 2016 ligt het ongeveer op het niveau van een sergeant. Voor de tweedegraads leraren en de leraren basisonderwijs geldt eveneens dat er sprake is van een daling over de jaren, alleen is deze minder sterk.

\subsection{Thema's uit de Lerarenagenda}

Het doel van de Lerarenagenda is het verhogen van de kwaliteit van de leraar en het onderwijs. Professionalisering en een sterke beroepsgroep zijn daarbij belangrijke thema's. Eén op de drie à vier leraren had zich tijdens de enquêteperiode in het op dat moment vrijwillige Lerarenregister ingeschreven. Ongeveer 60 procent daarvan gebruikt dat register ook daadwerkelijk en houdt zijn of haar professionaliseringsactiviteiten erin bij. De (nog) niet-gebruikers hebben twijfels over het nut van het register. Een beperkt deel ervan heeft meer principiële bezwaren tegen inschrijving.

Professionaliseringsactiviteiten van leraren spitsen zich toe op (korte) trainingen/workshops e.d. Binnen een tijdsbestek van één jaar neemt het overgrote deel van de leraren weleens aan dit soort activiteiten deel. Daarnaast heeft ook nog eens tussen de 20 en 30 procent van de leraren in het afgelopen jaar deelgenomen aan een vorm van scholing met een kwalificatieprogramma. Deze laatste categorie activiteiten wordt vooral voor en door de jongere leraren en minder voor de oudere leraar ingezet.

Als leraren participeren in netwerken blijkt dat vooral te zijn door aansluiting bij één (of meer) van de vakbonden. Bij de andere vormen van participatie zijn leraren in het voorgezet onderwijs wat actiever dan leraren in de andere beide sectoren. In po en mbo is vooral de deelname aan specifieke of algemene beroepsorganisaties kleiner.

Leraren die op verschillende manieren aan hun professionele ontwikkeling werken, blijken niet vaker van mening te zijn dat de bevolking en de ouders positiever tegen het lerarenberoep aankijken. Diverse elementen uit de Lerarenagenda (inschrijving in het lerarenregister, participatie in netwerken, deelname aan professionaliseringsactiviteiten) hangen niet of nauwelijks samen met hoe leraren de waardering van hun beroep door de buitenwereld inschatten. Het lijkt er daarmee niet op dat actieve participatie in netwerk- en professionaliseringsactiviteiten het zelfbeeld en de beroepstrots van de leraar beïnvloeden.

\subsection{Blik op de toekomst}

Een hoge status en een goed imago van de leraar zijn belangrijk omdat ze het werken in het onderwijs aantrekkelijk maken voor (aankomende) leraren. Meer waardering voor het leraarschap draagt bij aan een groter potentieel van goed opgeleide en gemotiveerde leraren. Dit is des te meer van belang gezien de grote verwachte tekorten in het primair onderwijs. Ook in het voortgezet onderwijs en het middelbaar beroepsonderwijs zullen er tekorten blijven voor een aantal vakken, bij een aantrekkende economie met 
name in vakken waarvoor veel concurrentie is op de arbeidsmarkt buiten het onderwijs. We zien echter dat de status van de leraren in het verleden is afgekalfd in samenhang met een daling van het salaris ten opzichte van andere sectoren en beroepen en een minder exclusieve positie op de arbeidsmarkt als beroep waarin veel hoogopgeleiden werkzaam zijn. Terwijl het imago van veel beroepen op de beroepenladder vrij stabiel is, kunnen we voor de leraren basisonderwijs en eerstegraads en tweedegraads leraren in het voorgezet onderwijs concluderen dat de positie op de beroepenladder in 2016 ten opzichte van 2006 en 1982 een daling heeft ondergaan. Ook de positie van de leraren mbo en de leraren lichamelijk opvoeding op de beroepenladder is in 2016 allesbehalve rooskleurig.

Om het tij te keren kan de uitvoering van de Lerarenagenda de status en het imago van de leraar verbeteren. Het betreft dan maatregelen als een strengere selectie gedurende de opleiding tot leraar, de nadruk op de professionalisering van de leraar en de versterking van de beroepsorganisatie van leraren, inclusief de invoering van het lerarenregister. Diverse elementen uit de Lerarenagenda (inschrijving in het lerarenregister, participatie in netwerken, deelname aan professionaliseringsactiviteiten) blijken echter vooralsnog niet in positieve zin samen te hangen met hoe leraren de waardering van hun beroep door de buitenwereld inschatten. Maar dit onderzoek is niet meer dan een nulmeting, dat over 3 tot 5 jaar om herhaling vraagt. Toch zal het ook in vervolgonderzoek erg moeilijk zijn om een causaal verband te leggen tussen de uitvoering van de Lerarenagenda en de status en het imago van leraren.

De waardering voor het leraarschap blijkt in 2016 niet hoog te zijn, waarbij tevens het lage zelfbeeld van de leraren opvalt. Een verbetering van deze waardering is een zaak van lange adem. Er dient dan over een langere periode consequent geïnvesteerd te worden in de verbetering van de arbeidsvoorwaarden, in kwalitatief goede lerarenopleidingen, in de verdere professionalisering van leraren, in de versterking van de beroepsorganisatie en in imagocampagnes om de aantrekkelijke kanten van een baan als leraar toe te lichten, voordat de resultaten zichtbaar zouden kunnen worden in de waarderingscijfers en in de positie op de beroepenladder. Als de status en het imago van het leraarschap inderdaad stijgen, verwachten we dat dat een bijdrage levert aan de kwaliteit van het onderwijs. Scholen zullen dan immers beter in staat zijn om gemotiveerde en ambitieuze jongeren te interesseren voor een baan in het onderwijs, en om kwalitatief goede leraren aan te trekken en te behouden. 


\section{REFERENTIES}

Boekholt, P.T.F.M. en E.P. de Booy (2002), Geschiedenis van de school in Nederland vanaf de middeleeuwen tot aan de huidige tijd, Koninklijke van Gorcum B.V., Assen.

Breen, R., en J.O. Jonsson (2005), Inequality of Opportunity in Comparative Perspective: Recent Research on Educational and Social Mobility, Annual Review of Sociology, Vol. 31, pp. 223-243.

Bosker, R., P. Sleegers en T. Wubbels (2015), Conceptueel kader, Professionaliteit van leraren, Nationaal Regieorgaan Onderwijsonderzoek (NRO).

Bijlsma, I., S. Dijksman, D. Fouarge en A. Künn-Nelen (2015), Winnaars en verliezers op de arbeidsmarkt 1996-2012, Tijdschrift voor Arbeidsvraagstukken, Vol. 31, pp. 106-123.

Bose, C., en P. Rossi (1983), Gender and Jobs: Prestige Standings of Occupations as Affected by Gender, American Sociological Review, Vol. 48, pp. 316-330.

CentERdata en MOOZ (2016), Loopbaanmonitor onderwijs, CentERdata, Tilburg.

Cörvers, F. (2014), De arbeidsmarkt voor leraren: theorie, beleid en werkelijkheid, TPEdigitaal, Vol. 8(4), pp. 132-149.

Cörvers, F. (2014a), De ambtenaar maakt het verschil, In: Alles voor het publiek domein, CAOP, Den Haag, pp. 22-25.

CPB (2013), Arbeidsmarkt leraren: aanpassingsmechanismen en aangrijpingspunten voor beleid, Uitgevoerd op verzoek van het ministerie van Onderwijs, Cultuur en Wetenschap, CPB Notitie, 23 oktober, Den Haag.

CPB (2015), Evaluatie van de Lerarenbeurs: Aanvragers, Deelname en Afronding, Centraal Planbureau, Den Haag.

CPB (2016), Kansrijk onderwijsbeleid, Centraal Planbureau, Den Haag.

De Koning, H., en H. Kroon (ed., 2011), Op een dag ben je leraar. Zoektocht naar professionele identiteit van leraren, APS, Utrecht.

Dolton, P., en O.D. Marcenaro-Gutierrez (2011), If you pay peanuts do you get monkeys? A crosscountry analysis of teacher pay and pupil performance, Economic Policy, Vol. 26, pp. 5-55.

Dolton, P., en O. Marcenaro-Gutierrez, met V. Pota, M. Boxser, A. Pajpani (2013), Global Teacher Status Index, Varkey GEMS Foundation, October, London.

Edwards, A.L., en R. Gonzalez (1993), Simplified Successive Intervals Scaling, Applied Psychological Measurement, Vol. 17, pp. 21-27.

Eck, E. van, \& Heemskerk, I. (2009). Leraar worden. Kiezen voor opleiding en beroep, SBO, Den Haag.

Faber F. (1988). Een wet van niks? Mens en Maatschappij, Vol. 63(4), 366-382.

Ganzeboom, H. B. G., P.M. de Graaf en M. Kalmijn (1987), De culturele en de economische dimensie van beroepsstatus, Mens en Maatschappij, Vol. 62, pp. 153-175. 
Gemmeke, M. S.G. van Otterloo, J.J. van der Wel (2007), Onderwijsmeter 2007, Regioplan Beleidsonderzoek, Amsterdam.

Groenewegen, P.P., J. Hansen, H. Sixma, M. Krol, T. van der Weegen en W.C. Ultee (2007), Beroepsprestiges in Nederland: ontwikkelingen tussen 1982 en 2006, Conceptartikel gebruikt bij rapport Leerkracht!, NIVEL, Nederlands Instituut voor onderzoek van de Gezondheidszorg.

Heek, F. van, et al. (1958), Sociale stijging en daling in Nederland Leiden, Stenfert Kroese, Leiden.

Hollingshead, A. (1975), Four Factor Index of Social Status, Ongepubliceerd working paper.

Inspectie van het Onderwijs (2014), De sector lerarenopleidingen in beeld, Studiesucces, studenttevredenheid en aansluiting op de arbeidsmarkt, 8 oktober, Utrecht.

Jettinghof, K., en J. Scheeren (2010), Loopbanen in hetonderwijs? Analyse van de loopbaanontwikkeling van onderwijspersoneel, Sectorbestuur Onderwijsarbeidsmarkt (SBO), januari, Den Haag.

Kalmijn, M. (1987), De sociale positie van de onderwijzer: maatschappelijk aanzien, leefstijl en sociale herkomst van de beroepsgroep, Jeugd en Samenleving, Vol. 17, pp. 675-689.

Knol, H. en S. Kooiker. (1986), Determinanten van aanzien, Mens en Maatschappij, Vol. 61(2), pp. 169184.

Langenberg, H. en H. Lautenbach (2007), Beroeps Niveau Niet Westerse Allochtonen Lager, Sociaaleconomische Trends, 1e kwartaal 2007, Centraal Bureau voor de Statistiek.

Lautenbach, H. \& F. Otten (2007), Inkomen allochtonen blijft achter door lagere opleiding, Sociaaleconomische trends, 2e kwartaal 2007, Centraal Bureau voor de Statistiek.

Lenski G. (1954), Status crystallization: a non-vertical dimension of social status, American Sociological Review, Vol. 19, pp. 405-413.

Melser, C. (2004), Welke bedrijfstakken vergrijzen?, Sociaal-economische trends, 3e kwartaal 2004, Centraal Bureau voor de Statistiek.

Ministerie van OCW (1999), Overzicht onderzoeken studiekeuze jongeren, imago en zelfbeeld van leraren, oktober, Den Haag.

Ministerie van OCW (2013), De Lerarenagenda 2013-2020: de leraar maakt het verschil, Rijksoverheid, oktober, Den Haag.

Ministerie van OCW (2014), Voortgangsrapportage Lerarenagenda, Kamerbrief 678693, 8 oktober, Den Haag.

Ministerie van OCW (2015), Tweede voortgangsrapportage Lerarenagenda, Kamerbrief 841758, 4 november, Den Haag.

Ministerie van OCW, Trends in Beeld 2010, www.trendsinbeeld.minocw.nl

Mooij, M. de, I. Bottelberghs, M. Goedhuys, J. van den Tillaart en C. Wagner, Gelijk loon voor gelijk werk?, Centraal Bureau voor de Statistiek, Den Haag.

Pompe, J.H., en A. Rutges (1984), Het meten van beroepsprestige. Enige kanttekeningen bij een beroepsprestigeschaal voor de jaren tachtig, Kritische bijdragen, Mens en Maatschappij, Vol. 59, pp. 292-300.

Plantinga, S., M. van Diepen, R. Schildmeijer en M. van Bruxvoort (2008), Onderwijsmeter 2008, F1503, juni-juli, TNS NIPO, Amsterdam.

ROA (2013), Schoolverlaters tussen onderwijs en arbeidsmarkt 2012, ROA-R-2013/7, Universiteit Maastricht.

Rovers, H. (2014), Wat is de invloed van (niet-)werkende moeders op de beroepsstatus van hun kinderen?, Masterthesis Sociologie (begeleiders Ganzeboom en Pavlopoulos), Faculteit der Sociale Wetenschappen, Vrije Universiteit, Amsterdam. 
Sixma, H., en W. Ultee (1983), Een beroepsprestigeschaal voor Nederland in de jaren tachtig, Mens en Maatschappij, Vol. 58, pp. 360-382.

Stamet, Y. (2013), Duurzaam inzetbaar en mobiel, Secundaire analyse POMO 2012 voor het primair onderwijs, CAOP Research \& Europa, maart, Den Haag.

Sullerot, E. (1969), Geschiedenis en Sociologie van de Vrouwenarbeid, deel 2: De Vrouwenarbeid in onze tijd, uitgeverij Paul Brand, Bussum.

Van der Boom, E., en M. Stuivenberg (2013), Teaching and Learning International Survey (TALIS) 2013, Nationaal rapport Nederland, in opdracht van Ministerie van OCW. 



\section{BIJLAGE I: METHODOLOGISCHE VERANTWOORDING}

Voor het onderzoek is gebruik gemaakt van zowel secundaire analyses op bestaande gegevensbronnen als enquêtes onder verschillende respondentgroepen.

\section{Secundaire analyses}

Voor de secundaire analyses is gebruik gemaakt van databestanden die 'doorlopend' van aard zijn (dat wil zeggen: diverse metingen door de tijd) en die als betrouwbaar bekend staan. Er is vooral gebruik gemaakt van de schoolverlatersgegevens van het ROA (in dit rapport: VO-Monitor en $\mathrm{HBO}-M o n i t o r)$, de instroom- en uitstroomgegevens van DUO en diverse arbeidsmarktgegevens van het CBS.

Binnen de secundaire analyses is waar mogelijk onderscheid gemaakt tussen studenten en afgestudeerden van de pabo enerzijds en van de vo-lerarenopleidingen anderzijds. Tevens worden de gegevens over de lerarenopleidingen afgezet tegen de gegevens over het gehele hbo. In enkele gevallen wordt geen onderscheid gemaakt naar het type lerarenopleiding, maar naar het type onderwijssector waar leraren actief zijn (po, vo, $\mathrm{mbo})$.

De aandacht wordt bij de secundaire analyses, op enkele gevallen na, gericht op studenten, dan wel pas afgestudeerden aan de lerarenopleidingen. Onder deze groep van leraren zullen ontwikkelingen in het opleidingsniveau (bijvoorbeeld een strengere selectie aan de poort) of in de arbeidsmarktpositie immers het snelst zichtbaar zijn.

\section{Vragenlijstonderzoek imago en prestige}

Naast analyse van bestaande gegevensbronnen zijn er aanvullende gegevens verzameld. In totaal vijf soorten respondentgroepen zijn in het onderzoek betrokken door hen een vragenlijst voor te leggen.

- Leraren in po, vo en mbo

- Studenten aan de lerarenopleidingen (pabo, overige lerarenopleidingen)

- Scholieren in laatste twee jaar havo/vwo en mbo (sociaal pedagogische richting).

- Ouders van leerlingen in po, vo en mbo 
De steekproeven voor deze groepen zijn op verschillende manieren samengesteld en ze zijn deels ook op verschillende manieren benaderd voor het onderzoek. Per doelgroep is eigenlijk een maatwerk benadering ontworpen. In onderstaande tabel geven we daarvan een overzicht.

\begin{tabular}{|l|r|r|r|}
\hline Respondentgroep & Bron & $\begin{array}{r}\text { Omvang } \\
\text { steekproef }\end{array}$ & $\begin{array}{r}\text { Omvang } \\
\text { responsgroep }\end{array}$ \\
\hline $\begin{array}{l}\text { Leraren in po, vo en mbo } \\
\text { Studenten aan de lerarenopleidingen (pabo, overige }\end{array}$ & Flitspanel BZK & 4.388 & 2.406 \\
\hline $\begin{array}{l}\text { lerarenopleidingen) } \\
\text { Scholieren in laatste twee jaar havo/vwo en mbo (sociaal }\end{array}$ & DUO inschrijvingen & 2.492 & 287 \\
\hline pedagogische richting). & Panel TNS NIPO & & 732 \\
\hline $\begin{array}{l}\text { Ouders van leerlingen in po, vo en mbo } \\
\text { Algemene bevolking (Nederlandse bevolking van 18 jaar) }\end{array}$ & Panel TNS NIPO & & 1.108 \\
\hline
\end{tabular}

Voor de leraren in po, vo en mbo hebben we gebruik gemaakt van het zogenaamde Flitspanel van BZK. Dit is een internetpanel van werknemers in de (semi-)publieke sector. Het is een initiatief van de directie Arbeidszaken Publieke Sector (APS) van het Ministerie van Binnenlandse Zaken en Koninkrijksrelaties (BZK). Diverse ministeries, A\&O-fondsen, universiteiten en onderzoeksbureaus maken gebruik van het Flitspanel met uiteenlopende onderzoeken op het terrein van arbeidsvoorwaarden, arbeidsmarkt en arbeidsomstandigheden. Het panel is in 2006 geïnitieerd om snel en gefundeerd antwoord te kunnen geven op ( $\mathrm{ad} \mathrm{hoc)} \mathrm{beleidsvragen.} \mathrm{Onderzoek} \mathrm{onder} \mathrm{het} \mathrm{Flitspanel} \mathrm{wordt}$ vanaf 2013 in opdracht van het ministerie van BZK aangestuurd door het programma InternetSpiegel van de Stichting ICTU. Voor de uitvoering van onderzoeken via het Flitspanel werkt ICTU samen met een externe marktpartij GfK.

Het Flitspanel bestaat uit ruim 20.000 leden waarvan de achtergrondgegevens bekend zijn, waardoor diverse selecties mogelijk zijn (bijvoorbeeld op sector, functie, leeftijd of geslacht) en er representatieve uitspraken gedaan kunnen worden. Het panel wordt gevuld door respondenten aan het tweejaarlijkse POMO-onderzoek te vragen of zijn willen deelnemen. Het Personeels- en Mobiliteitsonderzoek (POMO) is een grootschalig uitgezette enquête onder medewerkers van de publieke sector. Ambtenaren uit alle overheidssectoren wordt gevraagd naar uiteenlopende aspecten van hun werk, zoals mobiliteit en inzetbaarheid, werkbeleving en gesprekken met leidinggevenden. Vanaf 1999 is het POMO tweejaarlijks uitgevoerd in opdracht van de directie Arbeidszaken Publieke Sector (APS) van het ministerie van BZK. De meest recente meting dateert van juni 2016.

Studenten aan de lerarenopleiding hebben we benaderd door hen een brief op hun huisadres te sturen. Daarvoor hebben we gebruik gemaakt van de dienstverlening van DUO die de BRON HO gegevens beheert. Op grond van de inschrijvingen in BRON HO 
is een steekproef samengesteld van voltijdstudenten aan de lerarenopleidingen, zowel pabo als de universitaire lerarenopleiding en de reguliere lerarenopleidingen (tweede graad). Deze studenten hebben een brief ontvangen met het verzoek om deelname aan het onderzoek door een vragenlijst op internet in te vullen (de brief bevatte daarvoor een inlogcode).

Leerlingen in het voortgezet onderwijs en mbo, ouders van leerlingen en een afspiegeling van de Nederlandse bevolking zijn via het panel van TNS NIPO benaderd. TNS NIPObase is een grote database met daarin meer dan 140.000 respondenten, waaruit een representatieve steekproef van ouders en de algemene bevolking kan worden getrokken. De TNS NIPObase omvat de Onderwijspanels. Daarmee kunnen eenvoudig en snel online vragenlijsten worden uitgezet onder de scholieren in laatste twee jaar havo/vwo en mbo sociaal-pedagogisch. De steekproeven en de data die TNS NIPO via de panels verzamelt zijn van hoge kwaliteit: representativiteit, betrouwbaarheid en een hoog responspercentage (>70\%) zijn gegarandeerd. Minimaal eens per jaar worden alle gegevens in de panels geactualiseerd.

Alle groepen hebben een internetvragenlijst ingevuld. De vragenlijsten die aan de verschillende respondentgroepen worden voorgelegd, kennen een grote mate van overlap (zie bijlage IV). Ze bestaan deels uit algemene vragen over de waardering voor het lerarenberoep. De deelvragen gaan wat betreft de leraren over de sector onderwijs als werkgever en hun kennis van of deelname aan de Lerarenagenda. Leerlingen en studenten vragen we naar hun verwachtingen over de beroepen in het onderwijs. Bovendien zijn respondenten in de groep 'Nederlandse bevolking' gevraagd om diverse beroepen (waaronder die van leraar) op het maatschappelijk aanzien te ordenen om op die manier een beroepenladder op te stellen.

Bij de ontwikkeling van de vragenlijst (in de diverse varianten) zijn alle onderzoekers binnen het project betrokken geweest. De vragenlijsten zijn vooraf uitgetest op de diverse respondentgroepen ('pre-testing'). Voor de samenstelling van de vragenlijsten is uitdrukkelijk geput uit de inzichten die in eerdere studies zijn gebruikt, in het bijzonder de eerdere Onderwijsmonitor van TNS NIPO (Plantinga et al., 2008) en het recente statusonderzoek van Dolton et al. (2013) en van Groenewegen et al. (2007), het TALIS onderzoek 2013 (OECD, en onderzoek van het SBO naar het opleidingsstelsel van de lerarenopleidingen vo (Jettinghoff en Scheeren, 2011).

De vragenlijsten zijn afgenomen in een tijdsbestek van 3 à 4 weken in de periode maartapril 2016. Er heeft voor de groep studenten in de lerarenopleiding geen rappel kunnen plaatsvinden. Deze groep is door middel van een brief uitgenodigd voor deelname aan het onderzoek en een rappel via die weg paste niet in de planning. Bij de andere groepen (die per mail zijn benaderd) heeft wel een rappel via de mail plaatsgevonden. 



\section{BIJLAGE II: RESPONSANALYSE}

Voor de leraren uit het Flitspanel is een responsanalyse uitgevoerd om na te gaan of de responsgroep naar de achtergrondkenmerken geslacht en leeftijd een goede afspiegeling vormt van de totale populatie van leren op deze kenmerken. Daarvoor zijn de openbare populatiegegevens van DUO over leraren gebruikt, die afkomstig zijn van de salarisverwerkers (https://duo.nl/open_onderwijsdata/).

In onderstaande tabel zijn de resultaten van die vergelijking opgenomen.

\begin{tabular}{|l|r|r|r|r|r|r|r|}
\hline & \multicolumn{4}{|c|}{ DUO 2015 } & \multicolumn{4}{|c|}{ Flitspanel respons } \\
\hline & PO & V0 & MBO & PO & V0 & MBO \\
\hline man & 0,12 & 0,48 & 0,47 & 0,20 & 0,56 & 0,60 \\
\hline vrouw & 0,88 & 0,52 & 0,53 & 0,80 & 0,45 & 0,40 \\
\hline 25 & 0,03 & 0,04 & 0,02 & 0,01 & 0,01 & 0,00 \\
\hline $25-35$ & 0,27 & 0,24 & 0,16 & 0,16 & 0,10 & 0,04 \\
\hline $35-45$ & 0,24 & 0,22 & 0,18 & 0,20 & 0,16 & 0,12 \\
\hline $45-55$ & 0,21 & 0,22 & 0,27 & 0,29 & 0,31 & 0,35 \\
\hline $55-65$ & 0,24 & 0,27 & 0,37 & 0,34 & 0,42 & 0,49 \\
\hline $65+$ & 0,00 & 0,01 & 0,01 & 0,00 & 0,01 & 0,00 \\
\hline
\end{tabular}

We zien hier dat ten opzichte van de populatie mannen en met name oudere leraren $(45+)$ in de responsgroep zijn oververtegenwoordigd. Dat geldt voor alle sectoren. Er is daarom een weging toegepast, waarbij per onderwijssoort de verdeling in de responsgroep naar leeftijd in overeenstemming is gebracht met de leeftijdscategorieën in de populatie.

Voor de studenten aan de lerarenopleidingen is een steekproef van 2492 studenten getrokken. Deze was min of meer gelijk verdeeld over studenten aan de pabo enerzijds (1248) en studenten aan de tweedegraads lerarenopleidingen en ulo's anderzijds (1244) . De respons onder de pabo-studenten lag hoger (165 studenten, 13,2\%) dan de respons onder studenten aan de tweedegraads en universitaire leraren opleidingen (122 studenten, 9,8\%). We hebben hier geen weging toegepast aangezien we voor deze groepen steeds apart rapporteren: de oordelen van pabo-studenten over aspecten van het leraarschap in het primair onderwijs en de studenten aan de tweedegraads lerarenopleidingen en ulo's over aspecten van het leraarschap in het voortgezet onderwijs en middelbaar beroepsonderwijs. 



\section{BIJLAGE III: SETS MET BEROEPEN}

Omdat 138 beroepen ordenen een ondoenlijke taak is, heeft iedere respondent (in de categorie Nederlandse bevolking) een set van 28 beroepen beoordeeld. Dat bestond uit zes beroepen die door iedereen zijn beoordeeld en uit twee sets van 11 beroepen die door verschillende respondenten zijn beoordeeld. Hieronder geven we het overzicht van de aantallen respondenten per set van beroepencombinaties. Uiteindelijk is ieder set van beroepen op maatschappelijk aanzien beoordeeld door tussen de 149 en 191 respondenten.

\begin{tabular}{|c|c|c|c|}
\hline Combinatie sets & Aantal respondenten & Beroepenset ( 11 beroepen) & Beoordeling door respondenten \\
\hline Set 12 en 1 & 93 & Set 1 & 169 \\
\hline Set 1 en 2 & 88 & Set 2 & 181 \\
\hline Set 2 en 3 & 98 & Set 3 & 186 \\
\hline Set 3 en 4 & 89 & Set 4 & 187 \\
\hline Set 4 en 5 & 81 & Set 5 & 170 \\
\hline Set 5 en 6 & 74 & Set 6 & 155 \\
\hline Set 6 en 7 & 99 & Set 7 & 173 \\
\hline Set 7 en 8 & 92 & Set 8 & 191 \\
\hline Set 8 en 9 & 74 & Set 9 & 166 \\
\hline Set 9 en 10 & 82 & Set 10 & 156 \\
\hline Set 10 en 11 & 73 & Set 11 & 155 \\
\hline Set 11 en 12 & 76 & Set 12 & 149 \\
\hline Totaal & 1019 & & \\
\hline
\end{tabular}

In onderstaande tabel geven we een overzicht van de beroepen per set. 
$\left\|\left|\left\|_{1}\right\|\right|\right\|$ | |l| |n| |1|||||||| $\|$, \|\|\|\|\|\|

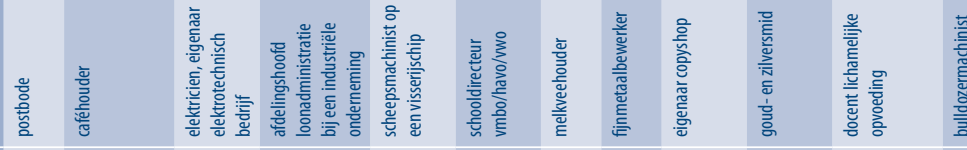
II |||||||| IIIIIII |II! I IIII II IIIIIIIn!|| \|\|$\|\| h\|\| \mid$, $\|$ IIIII |||| \|\|\|\|\|\|\|\|

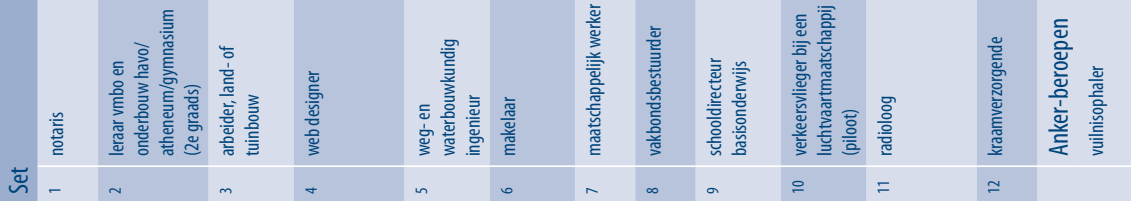




\section{BIJLAGE IV: VRAGENLIJSTEN}

This questionnaire was written according to TNS quality procedures

Q001 - Q001: DUMMY: doelgroepselectie

Single coded

\section{Dummy}

Deze vraag wordt niet voorgelegd aan respondenten

Normal

$\begin{array}{ll}1 & \text { Docenten vo } \\ 2 & \text { Docenten mbo } \\ 3 & \text { Docenten niet-bekostigd onderwijs } \\ 4 & \text { Studenten aan de lerarenopleidingen vo en mbo (1ste en } 2 \text { e graads) } \\ 5 & \text { Studenten PAB0 } \\ 6 & \text { Leerlingen/studenten havo } \\ 7 & \text { Leerlingen/studenten vwo } \\ 8 & \text { Leerlingen/studenten mbo } \\ 9 & \text { Ouders van leerlingen po (kind < 12jr) } \\ 10 & \text { Ouders van leerlingen/studenten vo (kind }>12 \text { jaar) } \\ 11 & \text { Ouders van leerlingen/studenten mbo (kind }>12 \text { jaar) } \\ 12 & \text { Nederlandse bevolking po } \\ 13 & \text { Nederlandse bevolking vo } \\ 14 & \text { Nederlandse bevolking mbo }\end{array}$

Ask only if Q001 - Q001,4,5

B001: Studenten lerarenopleidingen

Scripter notes: Invoegen bij vragen in dit blok bij: [variable text depending 01]

Begin block if Q1 = 4 variable text :'voortgezet onderwijs of middelbaar beroepsonderwijs'

if $\mathrm{Q} 1=5$ variable text : 'basisonderwijs' 
B002: Waardering lerarenberoep

Begin block

Q007 - 0007: ST5

Matrix

Number of statements: 6 | Number of Scales: 6

In hoeverre ben je het eens met onderstaande stellingen?

Leraren in het [variable text depending Q1]:

Random

$\begin{array}{lll}\begin{array}{l}\text { helemaal mee eens } \\ \text { mee eens }\end{array} & \begin{array}{l}\text { mee eens mee oneens } \\ \text { noch mee } \\ \text { oneens }\end{array} & \begin{array}{l}\text { helemaal mee weet niet } \\ \text { oneens }\end{array}\end{array}$

weten over het

algemeen goed hoe ze

kennis en vaardigheden

aan leerlingen kunnen

overdragen

kunnen leerlingen over

het algemeen goed

motiveren

hebben over het

algemeen voldoende

vakkennis (kennis van

de vakken waarin ze

lesgeven)

zijn over het algemeen

voldoende opgeleid

om hun vak goed uit te

oefenen

kunnen over het

algemeen goed met

ouders omgaan

kunnen over het

algemeen goed met

leerlingen/jongeren

omgaan

Q003 - 0003: ST1

Single coded

Denk je dat de Nederlandse bevolking in het algemeen (dus niet alleen ouders) veel of weinig waardering heeft voor leraren in het [variable text depending Q1]?

Normal

$\begin{array}{ll}1 & \text { Heel veel waardering } \\ 2 & \text { Tamelijk veel waardering } \\ 3 & \text { Noch veel, noch weinig waardering } \\ 4 & \text { Tamelijk weinig waardering } \\ 5 & \text { Heel weinig waardering }\end{array}$

Q004-0004: ST2 Open

Wat zijn volgens jou de belangrijkste redenen waarom Nederlanders in het algemeen (load in answer Q003) voor leraren hebben?

Je kunt je antwoord ook in steekwoorden noteren als je wilt. 
Q005 - Q005: ST3

Single coded

Denk je dat de Nederlandse bevolking (dus niet alleen ouders) gedurende de laatste 20 jaar meer of minder waardering hebben gekregen voor leraren in het [variable text depending 01$]$ ?

\section{Normal}

$1 \quad$ Veel meer waardering

$2 \quad$ Meer wardering

3 Noch meer, noch minder waardering

$4 \quad$ Minder waardering

$5 \quad$ Veel minder waardering

Q006- 0006: ST4 Single coded

Denk je dat ouders van leerlingen in het algemeen veel of weinig waardering hebben voor leraren in het in het [variable text depending Q1]?

Normal

$1 \quad$ Heel veel waardering

2 Tamelijk veel waardering

3 Noch veel, noch weinig waardering

$4 \quad$ Tamelijk weinig waardering

$5 \quad$ Heel weinig waardering

B002: Waardering lerarenberoep

End block

B003: Verwachting beroepen in het onderwijs

Begin block

Q008 - Q008: ST6

Matrix

Number of statements: 15 |Number of Scales: 5

Hoe belangrijk zijn of waren de volgende motieven voor het kiezen van je opleiding?

Random

$\begin{array}{lllll}1 & 2 & 3 & 4 & 5 \\ \text { speelde } & & & & \text { speelde een } \\ \text { geen rol } & & & & \\ \text { belangrijke rol }\end{array}$

De opleiding moet inhoudelijk

interessant zijn

Het specifieke beroep dat ermee is uit

te oefenen, moet aanspreken

De opleiding moet goed aansluiten

bij mijn capaciteiten en vaardigheden

Ik moet de opleiding met een

redelijke inspanning tot een goed

einde kunnen brengen

De opleiding moet een grote kans op

een baan geven

De opleiding moet veel

mogelijkheden bieden om

praktijkervaring op te doen 
De opleiding moet veel of brede beroepsmogelijkheden bieden

De opleiding moet duidelijk beroepsgericht zijn

Met de opleiding moet ik een baan met een hoog salaris kunnen krijgen

In de opleiding moet veel aandacht zijn voor onderzoeksvaardigheden

In de opleiding moet veel aandacht zijn voor theorie

Het beroep moet veel

maatschappelijk aanzien/status

geven

De opleiding moet de mogelijkheid bieden van een verkorte onderwijsroute of vrijstellingen

In de opleiding moet een combinatie van tegelijkertijd werken en leren mogelijk zijn

Andere motieven

Ask only if Q008 - Q008 ST $=15 \& \mathrm{SC}=5,4$

$0102-0102$ :

Open

Je hebt aangegeven dat andere motieven een (belangrijke) rol speelden bij het kiezen van je opleiding. Welke motieven speelden hierbij een rol?

Q009 - Q009: ST7

Matrix

Number of statements: $10 \mid$ Number of Scales: 5

Wat trekt je aan het beroep van leraar?

Random

$\begin{array}{lllll}1 & 2 & 3 & 4 & 5 \\ \begin{array}{l}\text { Speelt } \\ \text { geen rol }\end{array} & & & & \begin{array}{l}\text { Speelt } \\ \text { belangrijke rol }\end{array}\end{array}$

Werken met kinderen/jongeren

Overdragen van kennis

Maatschappelijk nuttig bezig zijn

als leraar

Veel vakanties

Flexibele werktijden en/of

mogelijkheden tot deeltijdwerk

Vakinhoudelijke interesse

Veel afwisseling in het beroep van

leraar

Zelfstandig kunnen werken als leraar 
Mogelijkheid tot zelfontplooiing

Ander aspect

Ask only if Q009- $\mathrm{Q} 009 \mathrm{ST}=10 \& \mathrm{SC}=4,5$

Q103 - Q103: Open

Not back

Je hebt aangegeven dat een ander aspect jou aantrekt van het beroep leraar. $0 \mathrm{~m}$ welk aspect gaat het?

Q010 - Q010: ST8

Wat wil je gaan doen na het afronden van je huidige opleiding?

Single coded

Normal

$1 \quad$ Les geven in het onderwijs

$2 \quad$ Een vervolgopleiding gericht op beroepen binnen het onderwijs

3 Een vervolgopleiding gericht op beroepen buiten het onderwijs

$4 \quad$ lk geef de voorkeur aan een baan als leraar in combinatie met een andere baan, namelijk.... * Open

$5 \quad$ Ik overweeg geen les te gaan geven, maar een andere baan te zoeken binnen of buiten het onderwijs

96

anders, namelijk... *Open *Position fixed

99 weet niet ${ }^{*}$ Position fixed ${ }^{*}$ Exclusive

Ask only if Q010 - Q010,1,4

Q011 - Q011: ST9

Multi coded

Aan welk(e) onderwijstype(n) zou je het liefste les willen geven?

Normal

1

Basisonderwijs

2

Speciaal basisonderwijs

3

Speciaal onderwijs

4

Voortgezet speciaal onderwijs

5

Voortgezet onderwijs vmbo

6

Voortgezet onderwijs havo (eerste graad)

7

Voortgezet onderwijs havo (tweede graad)

$8 \quad$ Voortgezet onderwijs vwo (eerste graad)

$9 \quad$ Voortgezet onderwijs vwo (tweede graad)

$10 \quad$ Middelbaar beroepsonderwijs

$11 \quad$ Particulier onderwijs

99 weet niet * Position fixed ${ }^{*}$ Exclusive

Scripter notes: if $\mathrm{Q} 1=4$ show anwers $4,5,6,7,8,9,10,11,99$ 
Q012 - Q012: ST10

We geven hieronder zes hbo-beroepen weer. Kun je aangeven welk bruto salaris pas afgestudeerden met een opleiding gericht op dit beroep gemiddeld verdienen in een voltijdsbaan?

\section{Geef aan welk salaris het best overeenkomt.}

Random

$1 \quad$ Leraar basisonderwijs $€ 2130$

2 Leraar voortgezet onderwijs algemene vakken $€ 2740$

3 Leraar voortgezet onderwijs beroepsgerichte vakken $€ 2580$

4 Communicatie-adviseur $€ 2060$

$5 \quad$ Elektrotechnisch ingenieur $€ 2530$

6 Informaticus $€ 2360$

B003: Verwachting beroepen in het onderwijs

End block

B004: Achtergrondkenmerken studenten lerarenopleiding

Begin block

Q013 - 0013: ST11

Numeric

$\operatorname{Min}=1 \mid \operatorname{Max}=10$

In welk leerjaar of studiejaar van de opleiding zit je?

Q014 - 0014: ST12

Wat is je geslacht?

Normal

$1 \quad \operatorname{man}$

2 vrouw

Q015 - Q015: ST13

Numeric

Min $=1920 \mid$ Max $=1999$

Wat is je geboortejaar?

Q016- 0016: ST14 Multi coded

Waren je ouders werkzaam als leraar in het onderwijs?

Meerdere antwoorden zijn mogelijk.

Normal
$1 \quad$ Nee ${ }^{*}$ Exclusive
2 Ja, mijn moeder
3 Ja, mijn vader

B004: Achtergrondkenmerken studenten lerarenopleiding End block 
0096 - 0096: Text

Not back

Dat waren alle vragen. Zeer veel dank voor je deelname aan het onderzoek!

B001: Studenten lerarenopleidingen End block

Ask only if Q001 - Q001,6,8,7

B005: Leerlingen in voortgezet onderwijs en middelbaar beroepsonderwijs

Scripter notes: Invoegen bij vragen in dit blok bij: [variable text depending Q1] muv Q18

Begin block

if $Q 1=6$ variable text:'leerlingen'

if $\mathrm{Q1}=7$ variable text:'leerlingen'

if $Q 1=8$ variable text:'studenten'

B006: Waardering lerarenberoep

Begin block

Q018 - 0018: LL2

Matrix

Number of statements: 6 | Number of Scales: 6

In hoeverre ben je het eens met onderstaande stellingen?

Leraren in het [variable text depending 01$]$...

Random

$\begin{array}{llllll}\begin{array}{l}\text { helemaal } \\ \text { mee }\end{array} & \text { mee } & \text { mee eens } & \text { mee } & \text { helemaal } & \text { weet } \\ \text { noch mee } & \text { oneens } & \text { mee } & \text { niet } \\ \text { eens } & & \text { oneens } & & \text { oneens } & \end{array}$

weten over het algemeen goed

hoe ze kennis en vaardigheden aan

leerlingen kunnen overdragen

kunnen leerlingen over het algemeen

goed motiveren

hebben over het algemeen

voldoende vakkennis (kennis van de

vakken waarin ze lesgeven)

zijn over het algemeen voldoende

opgeleid om hun vak goed uit te

oefenen

kunnen over het algemeen goed met

ouders omgaan

kunnen over het algemeen goed met

leerlingen omgaan

Scripter notes: if $Q 1=6$ variable text:'voortgezet onderwijs'

if $\mathrm{Q1}=7$ variable text:'voortgezet onderwijs'

if $\mathrm{Q1}=8$ variable text:'middelbaar beroepsonderwijs'

Q017 - Q017: LL1

Single coded

Denk je dat de Nederlandse bevolking in het algemeen (dus niet alleen ouders) veel of weinig waardering heeft voor leraren?

Normal

$1 \quad$ Heel veel waardering 
$2 \quad$ Tamelijk veel waardering

$3 \quad$ Noch veel, noch weinig wardering

$4 \quad$ Tamelijk weinig waardering

$5 \quad$ Heel weinig waardering

Q101 - Q101: LL16

Open

Wat zijn volgens jou de belangrijkste redenen waarom Nederlanders in het algemeen (load in answer Q017) voor leraren hebben?

Je kunt je antwoord ook in steekwoorden noteren als je wilt.

Q019 - Q019: LL3

Multi coded

Welke twee van onderstaande personen beantwoorden voor jou het meest aan het beeld van een leraar in het [variable text depending Q1]?

Random

5 pictures

B006: Waardering lerarenberoep

B007: Verwachting beroepen in het onderwijs

Q020 - Q020: LL4

Heb je al een keuze gemaakt wat je direct na deze opleiding wilt gaan doen?

Normal

1 Ja

$2 \quad$ Nee

Ask only if Q020 - Q020,1

Q021 - Q021: LL5

Wat wil je dan gaan doen direct na deze opleiding?

Normal

1 Verder leren op de universiteit; lerarenopleiding

2 Verder leren op hbo; lerarenopleiding

3 Verder leren op universiteit; geen lerarenopleiding

$4 \quad$ Verder leren op hbo; geen lerarenopleiding

13 Verder leren op vwo

$5 \quad$ Verder leren op mbo

6 Tijdje iets anders doen

$7 \quad$ Studeren in buitenland

$8 \quad$ Reizen

9 Werken en leren op hbo (duaal)

10 Werken en leren op mbo

11 Werken

12 Zelfstandig ondernemen
End block

Begin block

Single coded

Single coded 
Scripter notes: 0 nly show options 1 and 3 if $01=7$

Only show option 10 and 13 if $Q 1=6$

Ask only if NOT Q021 - Q021,1,2

Q022 - Q022: LL6

Single coded

Heb je overwogen om een opleiding tot leraar te volgen?

Normal

1 Ja

2 Nee

Ask only if Q022 - Q022, 1 or Q021 - Q021,1,2

0023 - 0023: LL7

Matrix

Number of statements: 12 |Number of Scales: 5

Wat trekt je aan in de lerarenopleiding?

Random

$\begin{array}{lllll}\begin{array}{l}1 \text { Speelt } \\ \text { geen rol }\end{array} & 2 & 3 & 4 & \begin{array}{l}5 \text { Speelt } \\ \text { belangrijke }\end{array}\end{array}$

rol

Werken met kinderen/jongeren

Overdragen van kennis

Maatschappelijk nuttig bezig zijn

als leraar

Veel vakanties

Flexibele werktijden en/of

mogelijkheden tot deeltijdwerk

Vakinhoudelijke interesse

Veel afwisseling in het beroep van

leraar

Zelfstandig kunnen werken als leraar

Mogelijkheid tot zelfontplooiing

Goede kans op een baan

Interessante opleiding

Ander aspect

Ask only if Q023 - Q023 ST $=12$ \& SC $=4,5$

Q104 - Q104:

Not back

Je hebt aangegeven dat een ander aspect jou aantrekt van de lerarenopleiding. $0 \mathrm{~m}$ welk aspect gaat het? 


\section{Waarom kies je niet, of heb je niet gekozen, voor een opleiding tot leraar?}

Meerdere antwoorden zijn mogelijk.

Random

1 De opleiding lijkt mij moeilijk/zwaar (bijv. taal, rekenen)

2 De opleiding lijkt mij saai (weinig uitdaging)

3 Beperkte loopbaan/carrièremogelijkheden in het onderwijs

4 Beperkte loopbaan/ carrièremogelijkheden met het diploma

$5 \quad$ Laag salaris

$6 \quad$ Het beroep van leraar trekt me niet aan

96 anders, namelijk... ${ }^{*}$ Open *Position fixed

Q025 - Q025: LL9

Single coded

We geven hieronder zes hbo-beroepen weer. Kun je aangeven welk bruto salaris pas afgestudeerden met een opleiding gericht op dit beroep gemiddeld verdienen in een voltijdsbaan?

Geef aan welk salaris het best overeenkomt.

Normal

1 Leraar basisonderwijs $€ 2130$

2 Leraar secundair onderwijs algemene vakken $€ 2740$

3 Leraar secundair onderwijs beroepsgerichte vakken $€ 2580$

4 Communicatie-adviseur $€ 2060$

$5 \quad$ Elektrotechnisch ingenieur $€ 2530$

$6 \quad$ Informaticus $€ 2360$

B007: Verwachting beroepen in het onderwijs

End block

B008: Achtergrondkenmerken leerlingen

Begin block

Q026- Q026: LL $11 \quad$ Numeric

$\operatorname{Min}=1 \mid \operatorname{Max}=10$

In welke klas/leerjaar zit je?

Q093 - 0093: LL12

IF $Q 001=6$ or 7 'Welk profiel heb je?' /IF $0001=8$ 'Welke opleiding volg je?'

Normal

$1 \quad$ Cultuur en maatschappij 
2 Economie en maatschappij

3 Natuur en techniek

$4 \quad$ Natuur en gezondheid

Scripter notes: IF Q001 $=6$ or 7 show catgoriees: 1, 2, 3, 4

IF $0001=8->$ open question

Q028 - 0028: LL 13

Single coded

Wat is je geslacht?

Normal

1 Man

2 Vrouw

Q029- 0029: LL 14

Numeric

Min $=1986 \mid$ Max $=2006$

In welk jaar ben je geboren?

Q030 - Q030: LL 15

Multi coded

Waren of zijn je ouders werkzaam als leraar in het onderwijs?

Meerdere antwoorden zijn mogelijk.

Normal
$1 \quad$ Nee
2 Ja, mijn moeder
3 Ja, mijn vader

B008: Achtergrondkenmerken leerlingen

End block

Q097 - 0097: Text

Not back

Dat waren alle vragen. Zeer veel dank voor je deelname aan het onderzoek!

B005: Leerlingen in voortgezet onderwijs en middelbaar beroepsonderwijs

End block

Ask only if Q001 - Q001,10,9,11

B009: Ouders van leerlingen in primair, voortgezet onderwijs en middelbaar beroepsonderwijs

Scripter notes: Invoegen bij vragen in dit blok bij: [variable text depending Q1]

Begin block

if $\mathrm{Q1}=9$ variable text:'basisonderwijs'

if $\mathrm{Q1}=10$ variable text:'voorgezet onderwijs'

if $01=11$ variable text:'middelbaar beroepsonderwijs'

B010: Waardering lerarenberoep

Q036 - 0036: 0 U6

Matrix

Number of statements: 6 | Number of Scales: 6

In hoeverre bent $u$ het eens met onderstaande stellingen?

Leraren in het [variable text depending Q1]: 
Random

$\begin{array}{llllll}\text { helemaal } & \text { mee } & \text { mee eens } & \text { mee } & \text { helemaal } & \text { weet } \\ \text { mee } & \text { eens } & \text { noch } & \text { oneens } & \begin{array}{l}\text { mee } \\ \text { mee }\end{array} & \text { niet } \\ \text { eens } & & & \text { oneens } & \\ & & \text { oneens } & & & \end{array}$

weten over het algemeen goed hoe ze kennis en vaardigheden aan leerlingen kunnen overdragen

kunnen leerlingen over het algemeen goed motiveren

hebben over het algemeen

voldoende vakkennis (kennis van de vakken waarin ze lesgeven)

zijn over het algemeen voldoende opgeleid om hun vak goed uit te oefenen

kunnen over het algemeen goed met ouders omgaan

kunnen over het algemeen goed met kinderen/jongeren omgaan

Q031 - Q031: 0 U1 Denkt u dat de Nederlandse bevolking in het algemeen (dus niet alleen ouders) veel of weinig waardering heeft voor leraren in het [variable text depending Q1]

Normal

$1 \quad$ Heel veel wardering

$2 \quad$ Tamelijk veel waardering

3 Noch veel, noch weinig waardering

$4 \quad$ Tamelijk weinig waardering

$5 \quad$ Heel weinig waardering

Q032 - 0032: 0U2

Open

Wat zijn volgens u de belangrijkste redenen waarom Nederlanders in het algemeen (load in answer Q031) voor leraren hebben?

Je kunt je antwoord ook in steekwoorden noteren als je wilt.

Q033 - Q033: 0 U3

Denkt u dat de Nederlandse bevolking in het algemeen (dus niet alleen ouders) gedurende de laatste 20 jaar meer of minder waardering heeft gekregen voor leraren in het [variable text depending 01]?

Normal

1 Veel meer waardering 
$3 \quad$ Noch meer, noch minder waardering

$4 \quad$ Minder wardering

$5 \quad$ Veel minder waardering

Q034 - 0034: 0 U4

Single coded

Hebt u zelf veel of weinig waardering voor leraren van uw kinderen in het [variable text depending Q1]?

Normal

$1 \quad$ Heel veel waardering

$2 \quad$ Tamelijk veel waardering

$3 \quad$ Noch veel, noch weinig wardering

$4 \quad$ Tamelijk weinig waardering

$5 \quad$ Heel weinig wardering

Q094 - Q094: 0 U5

Multi coded

Welke twee van onderstaande personen beantwoorden voor $u$ het meest aan het beeld van een leraar in het [variable text depending Q1]?

Random

$1 \quad$ Pictures Ares

2 Pictures Zeus

3 Pictures Apollo

$4 \quad$ Pictures Demeter

$5 \quad$ Pictures Hera

$6 \quad$ Pictures Aphrodite

Scripter notes: Insert validated pictures from TNS Needscope. These are 6 sets of 4 pictures of people's faces, European, Male.

Client notes: TNS Needscope-foto's invoegen

B010: Waardering lerarenberoep

End block

B011: Achtergrondkenmerken ouders van leerlingen / studenten

Begin block

Q037- 0037: 0 U7

Multi coded

In welke onderwijstypen volgen uw kinderen op dit moment onderwijs?

Meerdere antwoorden zijn mogelijk.

Normal

$1 \quad$ Basisonderwijs 


$\begin{array}{ll}2 & \text { Speciaal basisonderwijs } \\ 3 & \text { Speciaal onderwijs } \\ 4 & \text { Voortgezet speciaal onderwijs } \\ 5 & \text { Voortgezet onderwijs vmbo } \\ 6 & \text { Voortgezet onderwijs havo (leerjaar 1-3) } \\ 7 & \text { Voortgezet onderwijs havo (leerjaar 4-5) } \\ 8 & \text { Voortgezet onderwijs vwo (leerjaar 1-3) } \\ 9 & \text { Voortgezet onderwijs vwo (leerjaar 4-6) } \\ 10 & \text { Middelbaar beroepsonderwijs } \\ 11 & \text { Particulier onderwijs (privéscholen) }\end{array}$

Q038 - Q038: 0 U8

Multi coded

Waren uw ouders ooit werkzaam als leraar in het onderwijs?

Meerdere antwoorden zijn mogelijk

Normal

$\begin{array}{ll}1 & \text { Nee *Exclusive } \\ 2 & \text { Ja, mijn moeder } \\ 3 & \text { Ja, mijn vader }\end{array}$

Q039 - Q039: 0U9

Single coded

Bent u zelf leraar of docent (geweest) in het onderwijs?

Normal

1 Nee

2 Ja

Ask only if Q039 - Q039,2

Q041 - Q041: 0 U11

Multi coded

Aan welk(e) onderwijstype(n) geeft/gaf u les?

Normal

$1 \quad$ Basisonderwijs 


$\begin{array}{ll}2 & \text { Speciaal basisonderwijs } \\ 3 & \text { Speciaal onderwijs } \\ 4 & \text { Voortgezet speciaal onderwijs } \\ 5 & \text { Voortgezet onderwijs vmbo } \\ 6 & \text { Voortgezet onderwijs havo (eerste graad) } \\ 7 & \text { Voortgezet onderwijs havo (tweede graad) } \\ 8 & \text { Voortgezet onderwijs vwo (eerste graad) } \\ 9 & \text { Voortgezet onderwijs vwo (tweede graad) } \\ 10 & \text { Middelbaar beroepsonderwijs } \\ 11 & \text { Hoger beroepsonderwijs } \\ 12 & \text { Universitair onderwijs } \\ 13 & \text { Particulier onderwijs (privéscholen) }\end{array}$

Q042 - 0042: 0 U12

Multi coded

Welk soort vak(ken) geeft/gaf $u$ ?

Meerdere antwoorden zijn mogelijk.

Normal

1 Algemeen vormend (talen, wiskunde, geschiedenis, e.d.

2 Beroepsgericht (voeruigtechniek, bloembinden, fijnhoutbewerking, handel en verkoop, uiterlijke verzorging, e.d.

Q043 - Q043: 0 U13

Single coded

Als (een van) uw kind(eren) de capaciteiten en de interesse heeft om leraar te worden, zou u dan graag zien dat uw kind leraar wordt? Normal
1 Ja zeker wel
2 Ja misschien
3 Dat maakt me niet uit
$4 \quad$ Alleen als mijn kind het per se wil
$5 \quad$ Nee, zeker niet

Q044 - Q044: 0 U14

We geven hieronder zes hbo-beroepen weer. Kun je aangeven welk bruto salaris pas afgestudeerden met een opleiding gericht op dit beroep gemiddeld verdienen in een voltijdsbaan?

Geef aan welk salaris het best overeenkomt.

Normal

1 Leraar basisonderwijs $€ 2130$ 
2 Leraar secundair onderwijs algemene vakken $€ 2740$

3 Leraar secundair onderwijs beroepsgerichte vakken $€ 2580$

4 Communicatie-adviseur $€ 2060$

$5 \quad$ Elektrotechnisch ingenieur $€ 2530$

$6 \quad$ Informaticus $€ 2360$

B011: Achtergrondkenmerken ouders van leerlingen / studenten

End block

Q098 - 0098: Text

Not back

Dat waren alle vragen. Zeer veel dank voor uw deelname aan het onderzoek.

B009: Ouders van leerlingen in primair, voortgezet onderwijs en middelbaar beroepsonderwijs

End block

Ask only if Q001 - Q001,12,13,14

B012: Nederlandse bevolking overig

Scripter notes: Invoegen bij vragen in dit blok bij: [variable text depending Q1] muv Q095

Begin block

if $\mathrm{Q1}=12$ variable text:'basisonderwijs'

if $\mathrm{Q} 1=13$ variable text :'voortgezet onderwijs

if $\mathrm{Q1}=14$ variable text: 'middelbaar beroeps onderwijs

B013: Waardering lerarenberoep

Begin block

Q049- Q049: NL5

Matrix

Number of statements: 6 | Number of Scales: 6

In hoeverre bent $u$ het eens met onderstaande stellingen?

Leraren in het [variable text depending Q1]:

Random 


$\begin{array}{llllll}\begin{array}{l}\text { helemaal } \\ \text { mee }\end{array} & \begin{array}{l}\text { mee } \\ \text { eens }\end{array} & \begin{array}{l}\text { mee eens } \\ \text { noch } \\ \text { mee } \\ \text { oneens }\end{array} & \begin{array}{l}\text { mee } \\ \text { oneens }\end{array} & \begin{array}{l}\text { helemaal } \\ \text { mee } \\ \text { oneens }\end{array} & \begin{array}{l}\text { neet } \\ \text { niet }\end{array} \\ & & & \end{array}$

weten over het algemeen goed

hoe ze kennis en vaardigheden aan

leerlingen kunnen overdragen

kunnen leerlingen over het algemeen

goed motiveren

hebben over het algemeen

voldoende vakkennis (kennis van de

vakken waarin ze lesgeven)

zijn over het algemeen voldoende

opgeleid om hun vak goed uit te

oefenen

kunnen over het algemeen goed met

ouders omgaan

kunnen over het algemeen goed met

kinderen omgaan

Q045 - Q045: NL1

Single coded

Denkt u dat de Nederlandse bevolking in het algemeen (dus niet alleen ouders) veel of weinig waardering heeft voor leraren in [variable text depending Q1]?

Normal

$1 \quad$ Heel veel waardering

2 Tamelijk veel waardering

3 Noch veel, noch weinig waardering

$4 \quad$ Tamelijk weinig waardering

$5 \quad$ Heel weinig wardering

Q046- Q046: NL2

Open

Wat zijn volgens u de belangrijkste redenen waarom Nederlanders in het algemeen (load in answer Q045) voor leraren hebben? Je kunt je antwoord ook in steekwoorden noteren als je wilt.

Q047 - Q047: NL3

Denkt u dat de Nederlandse bevolking (dus niet alleen ouders) gedurende de laatste 20 jaar meer of minder waardering heeft gekregen voor leraren in het [variable text depending Q1]?

Normal

$1 \quad$ Veel meer waardering 
$3 \quad$ Noch meer, noch minder waardering

$4 \quad$ Minder waardering

$5 \quad$ Veel minder waardering

Q095 - 0095: NL4

Multi coded

Welke twee van onderstaande personen beantwoorden voor u het meest aan het beeld van een leraar in het [variable text depending Q1]?

Random

$1 \quad$ Pictures

Scripter notes: if Q1=12 variable text: 'leraar of lerares'

if $Q 1=13$ variable text: 'leraar of lerares'

if $01=14$ variable text: 'docent'

B013: Waardering lerarenberoep

End block

B014: Maatschappelijk aanzien: beroepenladder

Begin block

Q050 - 0050: NL6

Single coded

We willen u vragen om 10 beroepen te selecteren uit onderstaande lijst met het meeste aanzien. Het gaat hierbij niet om het aanzien zoals u dit zelf aan de beroepen zou toekennen, maar om het aanzien zoals men er in het algemeen over denkt.

Normal

1 van de 28 beroepen moet de respondent 10 selecteren

Q099 - 0099: NL6

Single coded

Not back

We vragen u nu een rangorde van beroepen te maken. Het beroep dat in de maatschappij het meeste aanzien heeft, wat het hoogst staat aangeschreven, komt bovenaan te staan; het beroep dat het minste aanzien heeft van de door u aangegeven selectie onderaan.

Normal

$1 \quad$ Load in answers $Q 050$

Q105 - 0105: NL6

Single coded

We willen u vragen om 9 beroepen te selecteren uit onderstaande lijst met het $\mathbf{m i n s t e}$ aanzien. Het gaat hierbij niet om het aanzien zoals u dit zelf aan de beroepen zou toekennen, maar om het aanzien zoals men er in het algemeen over denkt.

Normal

1 van de overgebleven 18 beroepen moet de respondent 9 beroepen selecteren

Scripter notes: Joblist excl. selected answers in Q050

Q106 - 0106: NL6

Single coded

Not back

We vragen u nu wederom een rangorde van beroepen te maken. Het beroep dat in de maatschappij het meeste aanzien heeft, wat het hoogst staat aangeschreven, komt bovenaan te staan; het beroep dat het minste aanzien heeft van de door u aangegeven selectie onderaan. 


\section{Normal}

$1 \quad$ Load in answers $Q 105$

Q107 - 0107: NL6

Single coded

We vragen u nu een rangorde van de overgebleven 9 beroepen te maken. Het beroep dat in de maatschappij het meeste aanzien heeft, wat het hoogst staat aangeschreven, komt bovenaan te staan; het beroep dat het minste aanzien heeft van de lijst onderaan.

Normal

1 rangorde laten maken

Scripter notes: inladen overgebleven 9 beroepen

Q052 - 0052: NL8

Single coded

Staat uw huidige beroep op de beroepenladder?

Normal

1 nee

2 ja, namelijk op plaats *0pen

GO TO Q054 - 0054

Q053 - 0053: NL9

Single coded

Zo nee, op welke plaats zou u uw eigen beroep neerleggen als het gaat om het aanzien dat uw beroep in de maatschappij geniet?

Tussen welke twee beroepen?

Normal

1 Tussen ...... en ............... * Open

B014: Maatschappelijk aanzien: beroepenladder

B015: Achtergrondkenmerken bevolking overig

End block

Q054 - 0054: NL11

Bent u zelf leraar of docent in het onderwijs?

Begin block

Normal

$1 \quad$ Nee

2 Ja

G0 T0 Q056 - Q056

Q056 - Q056: NL12

Multi coded

Aan welk(e) onderwijstype(n) geeft/gaf u les?

Single coded

Normal

$1 \quad$ Basisonderwijs 


$\begin{array}{ll}2 & \text { Speciaal basisonderwijs } \\ 3 & \text { Speciaal onderwijs } \\ 4 & \text { Voortgezet speciaal onderwijs } \\ 5 & \text { Voortgezet onderwijs vmbo } \\ 6 & \text { Voortgezet onderwijs havo (eerste graad) } \\ 7 & \text { Voortgezet onderwijs havo (tweede graad) } \\ 8 & \text { Voortgezet onderwijs vwo (eerste graad) } \\ 9 & \text { Voortgezet onderwijs vwo (tweede graad) } \\ 10 & \text { Middelbaar beroepsonderwijs } \\ 11 & \text { Hoger beroepsonderwijs } \\ 12 & \text { Universitair onderwijs } \\ 13 & \text { Particulier onderwijs (privéscholen) }\end{array}$

Ask only if Q054 - Q054,2

Q057 - 0057: NL13

Multi coded

Welk soort vak(ken) geeft/gaf u?

Meerdere antwoorden zijn mogelijk.

Normal

1 Algemeen vormend (talen, wiskunde, geschiedenis, e.d.)

2 Beroepsgericht (voertuigtechniek, bloembinden, fijnhoutbewerking, handel en verkoop, uiterlijk verzorging, e.d.

Q058 - 0058: NL14

Waren uw ouders ooit werkzaam als leraar in het onderwijs?

Multi coded

Meerdere antwoorden zijn mogelijk.

Normal

$1 \quad$ Nee

2 Ja, mijn moeder

3 Ja, mijn vader

B015: Achtergrondkenmerken bevolking overig

B012: Nederlandse bevolking overig

End block

Q100 - Q100: Text

Not back

Dat waren alle vragen. Zeer veel dank voor uw deelname aan het onderzoek. 